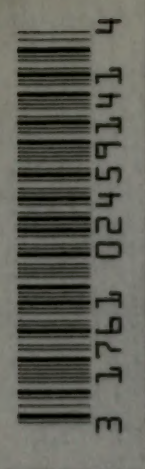

Cirvor

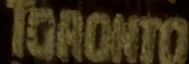
Lreeny 


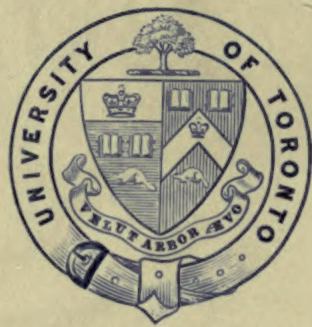

Dresented to

The Library

of the

University of Toronto

by

Professor Tackson. 

Digitized by the Internet Archive in 2007 with funding from Microsoft Corporation 
C UITUR E S

$$
\text { O F }
$$

UREDINEA E

\section{$1899-1921$}

sterangin)

By

J. C. A R T H U R

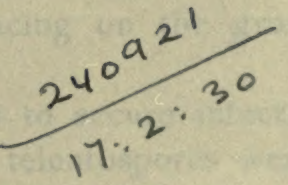


B 


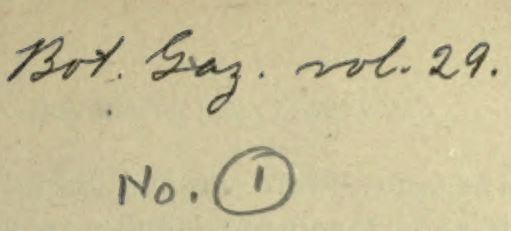

CULTURES OF UREDINEÆ IN $1899 .^{x}$

J. C. ARTH R.

With the exception of the very important results achieved by Thaxter in the study of American Gymnosporangia, together with similar work by Farlow, Halsted, Stewart, and Carver, only a few attempts have been made in America to trace the connection experimentally between the forms of the Uredineæ.

The three stages of the clover rust (Uromyces Trifolii) were shown by Howell to be genetically connected and the two forms of the raspberry rust (Gymnoconia interstitialis) by Clinton. A slight amount of work in this line of research, chiefly of a confirmatory character, was carried out between $\mathrm{I} 889$ and $\mathrm{I} 898$ by Bolley, Stuart, and the writer. The yet unpublished results of Carleton, obtained as part of the work of the division of vegetable physiology and pathology at Washington, ${ }^{2}$ complete the mention of all American efforts in this line that now occur to the writer.

The cultures made during the present season (1899), herein to be described, were conducted, with the exception of a single trial, under glass in the greenhouses of the Experiment Station at Purdue University, and upon plants in pots, the plants remaining under cover until the observations were completed. Material bearing teleutospores of a number of species was collected during the previous autumn and winter and preserved until needed by tying in loose muslin and placing on the ground out of doors.

The method generally adopted to secure infection was the same, whether æcidia, uredo, or teleutospores were in hand. The potted plant was first wet with an atomizer, parts covered with a bloom being rubbed with the fingers until the water

${ }^{x}$ Read before the Botanical Section of the Am. Assoc. Adv. Sci., Columbus meeting, August, 1899 .

2 Issued as Bulletin No. 16 since the paper was read. APRIL] 
ofdhered. The spores were scraped from the host material with anife blade and placed on definite areas of the plant to be infected, the parts marked by bits of string, and a bell jar placed over the whole plant. After a day or two the bell jar was removed. With most species, if the operation had been successful, the results began to appear in six to fourteen days.

In order that the simple procedure here outlined may uniformly give information that can be relied upon, many small precautions must be observed that cannot now be spoken of. In every case it is wise to first make a drop culture, to be sure that the spores are viable.

In the following outline of the work accomplished it is impossible to go into much detail, or mention all the items of interest that are naturally brought to mind. It is also impossible to adjust the nomenclature in accordance with the new knowledge which the cultures have furnished.

\section{Puccinia Phragmitis (Schum.) Körn.}

The host of this species, Phragmites communis, does not grow in the vicinity of Lafayette, Indiana, where the work was done, and I am indebted to Dr. J. J. Davis of Racine, Wis., and Professor C. E. Bessey, of Lincoln, Neb., for teleutosporic material. Abundance of æcidia were obtained by sowing the teleutospores upon Rumex crispus and $R$. obtusifolius, thus confirming the results obtained by European investigators. The dates are as follows:

May 2, Teleutospores (Wis.) sown on Rumex crispus; May 12 spermogonia ; May 15 , æcidia.

May 4, Teleutospores (Wis.) sown on Rumex obtusifolius; May 15, spermogonia; May 16 , æcidia.

May 9, Teleutospores (Neb.) sown on Rumex crispus; May 15, spermogonia; May -, æcidia.

May 9, Teleutospores (Neb.) sown on Rumex obtusifolius; May 15, spermogonia; May -, æcidia.

The preliminary drop cultures showed the most vigorous germination of teleutospores obtained with any species, and far surpassing most of those under observation. The sowings also 
produced a wealth of æcidia. From these facts one would infer that æcidia on Rumex should be common, for the teleutosporic condition occurs throughout the United States. Yet I am not aware of a single authentic record of Ecidium rubellum being found in North America. To be sure, it occurs in the earliest published list of American fungi by Schweinitz, who was a notably accurate observer. But his remark that the spots were usually sterile, makes it fairly certain that what he collected were not æcidia, but the spots made by fungi imperfecti. Both Professor Bessey and Dr. Davis at my suggestion made repeated and thorough search about the places where the teleutospores were found in their localities, but saw no æcidia. Improbable as it may seem, there yet appears to be no explanation of the remarkable vigor of this heteroecismal species, but to suppose that the recidia do occur in America, and that, so far, they have been overlooked.

\section{Puccinia Convolvuli Cast.}

The teleutospores of this very common species of rust on Convolvulus sepium were sown on the host, before the weather permitted it to start out of doors, and were duly followed by a rich development of spermogonia and subsequently of æcidia. It was thus experimentally shown to be an autœcious species, as has always been tacitly accepted. The dates are as follows: May 8, Teleutospores sown; May I6, spermogonia; June 6, æcidia.

\section{Puccinia Caricis (Schum.) Reb.}

The æcidiospores from Ecidium Urtica were sown May I 7 on the young leaves of Carex stricta and in eleven days were followed by uredospores. A sowing at the same date on Carex cephalophora gave no infection. This shows that Carex stricta is a host for Puccinia caricis, but there is reason to believe that it also acts as a host for other species of Puccinia. The American rusts on Carex are yet little understood.

\section{Uromyces Euphorbia C. \& $P$.}

There has been an almost uniform opinion among American botanists that the Æcidium occurring abundantly upon many 
species of Euphorbia is not genetically related to the brown rust equally abundant upon the same hosts. The evidence I have to offer is not conclusive, but, so far as it goes, must change this view. On June 20 æcidiospores from Euphorbia nutans were sown upon two plants of the same species and upon one plant of Euphorbia maculata. Nine days afterward uredo appeared upon one of the plants of Euphorbia nutuns, and in eleven days upon the other, followed in both cases by teleutospores after a time, the exact date not recorded, but the plant of E. maculata showed no infection.

Instead of speculating upon such meager data, I am inclined to believe that Uromyces Euphorbice is an autœcious species, and to await further cultures showing if it is separable into races.

\section{Phragmidium speciosum Fr.}

The intimate association of a cæoma, which is not distinguishable from Caoma miniata Schl., with this exclusively American species of Phragmidium, would have been accepted as sufficient evidence of its genetic connection, if the same form apparently had not been considered in Europe as the first stage of the very different Phragmidium mucronatum, a species that is also common in this country.

At the time when the teleutospores of Phr. speciosum were in germinating condition no potted plants of native roses were available, and sowings were made upon the leaves of a tea rose, the Kaiserin Augusta Victoria. The work was done by my assistant, Mr. William Stuart, and the dates are not at hand, but in due course of time many pustules of cæoma appeared. These bore every resemblance to the usual form, although they did not become very large, which may have been due to the host not being congenial.

It is probably safe to assume that the rose cæoma in this country belongs wholly to Phragmidium speciosum, or else that there are two species not at present separable.

6. Triphragmium Ulmariae (Schum.) Lk.

This species of rust, not heretofore reported for America, so far as the writer knows, was found in considerable abundance 
this spring near Lafayette, Ind., upon Ulmaria mbra (Spircea lobata), in the bright red cæoma stage. Feeling at first uncertain of the identity of the rust, the cæoma spores were sown upon the Ulmaria, and also upon Salix, Convolvulus, and I pomoea, with the result that it grew only upon Ulmaria, producing at first uredospores and afterward teleutospores. An after-sowing of uredospores upon Ulmaria gave a crop of more uredospores. The dates are as follows:

May 17, Cæomospores sown on Ulmaria rubra; May 30, uredo; July teleutospores.

May 17. Cæomospores sown on Salix longifolia; no infection.

May 23, Creomospores sown on Convolvulus sepium; no infection.

May 24, Creomospores sown on Ipomcea pandurata; no infection.

June 16, l/redospores sown on Ulmaria rubra; July —, uredospores.

\section{Puccinia Americana Lagh.}

This grass rust on various species of Andropogon is very common throughout North America, but has been generally confounded with Puccinia Andropogi Schw., which has the same range and affects the same hosts. The teleutospores are barely distinguishable, but the uredospores are entirely unlike those of $P$. Americana, being large and thin walled, those of $P$. Andropogi small and thick walled. The detection of the recidium is due to the careful observation of Mr. William Stuart, who noticed that plants of Pentstemon pubescens, growing near Andropogon bearing teleutospores of the previous year, were well covered with recidia (Ecidium Pentstemonis Schw.), while the same species in other localities was quite free. With this hint sowings were undertaken. Teleutospores from Andropogon scoparius were sown on Pentstemon pubescens and æcidia appeared in great abundance and vigor; æcidiospores were sown on Andropogron and large, thin-walled, brown uredospores appeared. The results were ample and complete, and were further emphasized by similar results subsequently obtained by Mr. Stuart. The dates are as follows :

May 3, Teleutospores from Andropogon scoparius sown on Pentstemon pubescens; May II, spermogonia ; May 20, æcidia. 
May 4, Teleutospores from $A$. furcatus sown on Enothera biennis; no infection.

May 15, Ecidiospores from $P$. pubescens sown on A. scoparius; May 29, uredo.

\section{Puccinia angustata $P k$.}

The detection of the æcidium of this common rust on Scirpus was also due to a fortunate observation. It was noticed that some plants of Lycopus, growing within a few feet of Srirpus atrovirens covered with last year's teleutospores, were well besprinkled with acidia (Ecidium Lycopi Ger.), while plants some distance away were free. Sowings of æcidia were made on the leaves of the Scirpus and characteristic uredo obtained. The hint was secured so late in the season that only one sowing was possible, but the result is thought to be measurably reliable.

May 23, Æcidiospores from Lycopus Americanus sown on Scirpus atrovirens: June 6, uredo.

\section{Puccinia Windsoria Schw.}

This rust occurs, often in great abundance, upon the much benamed grass, Triodia cuprea (Sieglingia seslevioides Scrib.), which in the days of Schweinitz was standing in the genus Windsoria. The name of the rust was applied in Burrill's Parasitic Fungi of Illinois fourteen years ago, to the very different rust on Muhlenbergia, hence great confusion has arisen, and in nearly all recent lists and treatises the name is misused.

The hint that led to successful cultures came from an observation upon proximity, as in the previous cases. A small shrub of Ptelea trifoliata was made conspicuous by the bright yellow spots of Acidium Ptelea B. \& C., and not ten feet away was a large clump of the grass with the dead stems and leaves black with teleutospores. Successful sowings of æcidiospores were made on the grass, but the season by this time had advanced so far that germinating teleutospores were no longer obtainable with which to try the reverse cultures. The dates are as follows: May 15, Teleutospores sown un Ambrosia trifida; no infection. May I7, Teleutospores sown on Napaa dioica; no infection. June 8, Ecidiospores sown on Triodia cuprea; June 15, uredo. June I6, Ecidiospores sown on Triodia cuprea; June 23, uredo. 
Io. Puccinja Vilfa $A$. \& $H$.

This species of rust, better known as $P$. Sydowiana Diet., is necessarily restricted in the vicinity of Lafayette to the few localities where the host, Sporobolus longifolius, ${ }^{3}$ is to be found. My attention was called to the fact by Miss Lillian Snyder that in such localities the exceedingly common upright verbenas were richly covered with Ecidium verbenicola K. \& S., and with no other species of æcidia in the vicinity. Going over the ground myself, I found that the verbena plants, Verbena stricta being particularly abundant, were more thickly studded with æcidia the closer they stood to tufts of rusted Sporobolus, and that fifty feet away from such source of infection they would be entirely free.

Cultures were undertaken in 1898 , but too late in the season to secure results. In the mean time a morphological resemblance was observed between the spores of Ecidium verbenicola and the uredospores of Puccinia Vilfa, that gave another hint at genetic relationship. Both sorts of spores were approximately obovate, with colorless walls, greatly thickened at the apex, and papillose instead of echinulate. Successful cultures have shown that these rather uncommon characters meant more than a coincidence in this case. It is the first time, so far as the writer knows, that any significant resemblance has been pointed out between the spores of æcidia and uredo of the same species.

For some unexplained reason I was unsuccessful in germinating the teleutospores of $P$. Vilfee, although they were taken a number of times directly from the field. But with æcidiospores the results were ample and convincing. The dates are as follows :

May 31, Æcidiospores from Verbena stricta on Sporobolus longifolius; June 10, uredo.

June 9, Ecidiospores from Verbena stricta on Sporobolus longifolius; June 2I, uredo.

${ }^{3}$ Since this paper was read I have discovered that the grass under observation was Sporobolus longifolius (Torr.) Wood, instead of S. asper, as given in the manuscript, and printed in Science $10: 565$, and Proc. A. A. A. S. 48: 299. The latter grass does nat grow in this region. 


\section{i i. Puccinia peridermiospora (E. \& T.) Avth.}

In studying the grass rusts it was noticed that a form on Spartina, well represented in American herbaria and usually called Puccinia Phragmitis, had uredospores similar to those of Puccinia Vilfa, just described. I searched through my collection of Ecidia to see if any species with corresponding apically thickened spores could be found, and was rewarded in the case of Acidium Fraxini Schw. With this morphological hint as the sole guide cultures were undertaken.

Spartina does not grow within many miles of Lafayette, and I am indebted to the kindness of Professor C. E. Bessey, of Lincoln, Neb., and Mr. H. H. Hume, of Ames, Iowa, for teleutosporic material upon Spartina cynosuroides. The teleutospores germinated with marked vigor, and were first sown on Ptelea trifoliata, the small plants obtained being mistaken for Fraxinus. When the mistake was discovered, and sowings were made on Fraximus viridis, infections were first secured. As no small plants of Fraxinus were available, the spores were sown upon cut twigs placed in water in the greenhouse, and upon a low branch of a large tree out of doors. There could be no fear of spontaneous infection, as the species does not occur in the region, either upon Spartina or Fraxinus, but the usual precautions were taken. The sowings were both successful. The dates are as follows :

May 8, Teleutospores (Neb.) sown on Ptelea trifnlinta; no infection.

May 9, Teleutospores (Neb.) sown on Ptelea trifoliata; no infection.

May 9, Teleutospores (Iowa) sown on Ptelea trifoliata; no infection.

May 1 5, Teleutospores (Neb.) suwn on Ptelea trifoliata; no infection.

May 17, Teleutospores (Iowa) sown on cut twigs of Fraxinus viridis; May 24, spermogonia; June 6, æcidia.

May 17, Teleutospores (Neb.) sown on tree out of doors of Fraxinus viridis;

May 29, spermogonia; June 8, æcidia.

\section{SUMMARY .}

The following are the eleven species of Uredineæ, whose æcidial and teleutosporic forms have been definitely connected by cultures : 
1. Puccinia Convolvuli Cast. and Acidium Calystegice Desm. with sowings of teleutospores.

2. Puccinia Phragmitis (Schum.) Körn. and Acidium rubellum Pers. with sowings of teleutospores.

3. Pucinia Americana Lagh. and Ecidium Pentstemonis Schw. with sowings of æcidicspores and teleutospores.

4. Puccinia Windsoria Schw. and Acidium Ptelea B. \& C. with sowings of acidiospores.

5. Puccinia Vilfa A. \& H. and Acidium verbenicola K. \& S. with sowings of æcidiospores.

6. Puccinia peridermiospora (E. \& T.) Arth. and Ecidium Fraxini Schw. with sowings of teleutospores.

7. Puccinia Caricis (Schum.) Reb. and Ecidium Urtica Schum. with sowings of æcidiospores.

8. Puccinia angustata Pk. and Acidium Lycopi Ger. with sowings of æcidiospores.

9. Uromyces Euphorbice C. \& P. and Ecidium Euphorbia Am. Auct. with sowings of æcidiospores.

ro. Phragmudium speciosum Fr. and Caoma miniata Am. Auct. with sowings of teleutospores.

II. Triphragmium Ulmaria (Schum.) Lk. and Caoma Ulmaria Thüm. with sowings of æcidiospores and uredospores.

Purdue University,

Lafayette, Ind. 



\title{
CULTURES OF UREDINEAE IN 1900 AND 1901
}

\author{
BY J. C. ARTHUR.
}

The first especially important cultures of plant rusts made by the writer were conducted in 1899 , and the results published in the Botanical Gazette for April 1900 (29:268-276). During the two following years only a small number of cultures were made, and for a number of reasons the results have not been put into type until now. This article is, therefore, the second of the series.

The method pursued in most cases in making the cultures has been stated in the preceding article. It was, in brief, to remove spores with a knife from the host, and place them on a dampened plant which it is desired to infect. The plants are grown in pots. After the spores are sown the whole plant is covered with a belljar and kept shaded for a day, or sometimes two days. The plants are then uncovered and placed on a greenhouse bench, where they remain until the period of observation is ended.

In Igoo the only cultures made that require mention were with Euphorbia rust. The results supplement and confirm those made in 1899 (Bot. Gaz. 29:270-27I). It was again found that spores from Euphorbia nutans would grow upon the same species, but not upon E. maculata. It seems quite probable that this rust, Uromyces euphorbiae C. \& P. possesses specialized forms. The record is as follows: 
July 21, Aecidiospores from Euphorbia nutans sown on E. nutans; July 30 , uredo.

July 21, Aecidiospores from E. nutans sown on E. maculata; no infection. uredo.

July 21, Uredospores from E. nutans sown on E. nutans; July 31, infection

July 21, Uredospores from E. nutans sown on E. maculata; no

There are two ways in which the right species of plant may be selected on which to make a sowing of a heterœcious rust. One is to sow upon any species known to harbor an aecidium, hoping after making a smaller or larger number of tests to hit upon the right one: This method in my own work has led to very meagre results, so slight, in fact, as scarcely to be worth the trouble. During I90I the following rusts were tried in this blind way, all being very common forms in this vicinity, only to ascertain that wrong plants were selected for the sowings or else the spores did not gain entrance possibly through defective treatment.

Puccinia emaculata Schw. on Panicum capillare was sown twice on Onagra biennis, with no infection.

Puccinia caricina DC. A form of this aggregate on Carex tetanica was sown on Erigeron annuus and Onagra biennis, with no infection.

Puccinia atkinsoniana Diet. on Carex lurida. The name of this species was unknown at the time the cultures were made, but through the kindness of Professor Atkinson, it has since been compared with type material and its status definitely settled. It was sown on Aster cordifolius, Aster paniculatus, Solidago serotina, Xanthium canadense, Ambrosia trifida, Impatiens aurea and Ribes cynosbati, with no infection.

Puccinia peckii (DeT.) Kellerm. on Carex trichocarpa. The names of both host and rust were unknown at the time the cultures were made. The host has since been found in fruit, and the rust has been successfully grown by Professor Kellerman and also the writer, as recorded in the preceding number of this Journal $(8: 20)$. Spores were sown on Aster cordifolius, Aster paniculatus, Solidago serotina, Solidago canadensis, Ribes cynosbati, Erigeron annuus, and Eupatorium perfoliatum, with no infection.

Puccinia rubigo-vera DC. A form of this aggregate of Bromus ciliatus was sown on Hepatica acuta and Viola cucullata, with no infection.

During I9OI the culture of seven species was successfully carried out. Three of these were in confirmation of previous work, as follows:

Puccinia caricis (Schum.) Reb. April 25, teleutospores from Carex stricta were sown on Urtica gracilis; May 2, spermogonia appeared, and May 5, æcidia. 
Puccinia angustata Pk. May 3, teleutospores from Scirpus atrovirens were sown on Lycopus americanus; May II, Spermogonia appeared, and May 20, aecidia.

Puccinia poculiformis (Jacq.) Wettst. May 2, teleutospores from Cinna arundinacea were sown on Berberis vulgaris; May I3, spermogonia appeared, and May 22, aecidia.

Of the remaining four species, all Carex rusts, the clues which led to successful cultures were obtained in the field, and have been mentioned and explained in an article in the Botanical Gazette for January of the present year. For three of these species it seems necessary to propose new names. All are yet insufficiently studied to determine their exact boundaries.

\section{PuCCINiA ALBiperidia sp. nov.}

O. Spermogonia amphigenous, small, pale orange.

I. Aecidia hypophyllous, small in circular clusters; substratum scarcely thickened; peridia white, low, margin incised, reflexed; spores pale yellow when fresh, subglobose, $15-20 \mu$ in diameter; wall thin, smooth.

II. Uredosori hypophyijous, small, round or oblong, soon naked; uredospores oblong, small, echinulate.

III. Teleutosori hypophyllous, globose or oblong, pulvinate, dark brown. Teleutospores oblong-cuneate, $17-24$ by $32-45 \mu$; apex semicircular or obtuse, thickened to half the length of the upper cell; side walls thin, slightly or not constricted; pedicel slender, colored, as long as the spore or shorter.

On Ribes cynosbati L. grown June, 1901 from teleutospores collected on Carex pubescens Muhl, Lafayette, Ind., April 30, 1901.

This species is characterized by the white or nearly white aecidia, which may be called Aecidium albiperidium. They are in marked contrast with the deep orange aecidia that are so abundant throughout North America on various species of Ribes. The only field collection known to the writer is one on Ribes gracile made at Decorah, Iowa, by E. W. D. Holway on June 2, I90I. When dry and faded the two forms of aecidia are much alike. Cultures were made as follows:

May 16, teleutospores from Carex pubescens sown on Aster paniculatus; no infection.

May -, teleutospores from Carex pubescens sown on Ribes cynosbati; May 30, spermogonia; June 9, aecidia.

\section{PuCcinta CARICIS-ERIGerontis sp. nov.}

O. Spermogonia epiphyllous, prominent, golden yellow.

I. Aecidia hypophyllous, in circular clusters; substratum slightly thickened; peridia short, much divided and recurved; aecidiospores yellow when fresh, isodiametric, 12-15 $\mu$ in diameter, wall thin, minutely tuberculate.

II. Uredosori hypophyllous, small, oblong, tardily naked; uredospores brownish-yellow when fresh, oval or obovate, small, 12-18 by 16-22 $\mu$ wall thin, thickly echinulate, pores 3 or 4 scattered. 
III. Teleutosori hypophyllous, small, oblong, pulvinate, blackish brown, ruptured epidermis evident; teleutospores clavate or oblongclavate, $14-20$ by $35-42 \mu$; septum above the middle; apex obtuse or truncate, much thickened; side walls thin; pedicel firm; colored, one fourth or one half the length of the spore. ette, Ind.

On Erigeron annuus (L.) Pers. and Carex festucacea Willd., Lafay-

This species is without doubt the Caeoma (Aecidium) erigeronatum Schw. (Trans. Amer. Phil. Soc. $4: 292$ ), and probably occurs on many species of Erigeron throughout North America. Cultures were made as follows:

April 25, teleutospores from Carex festucacea sown on Erigeron annuus; May 2, spermogonia; May 11, aecidia.

April 25, teleutospores from C. festucacea sown on Taraxacum taraxacum; no infection.

\section{Puccinia CARICIS-ASTERIS sp. nov.}

O. Spermogonia epiphyllous, yellow, punctiform, sunken in tissue of the leaf.

I. Aecidia hypophyllous, collected in groups on slightly swollen yellow or purplish spots, low, margin much divided and recurved; aecidiospores subglobose, $12-17 \mu$ in diameter, wall thin, minutely roughened.

II. Uredosori hypophyllous, oblong; uredospores oblong or obovate, 12-16 by 18-22 $\mu$; wall thin. echinulate; pores few, scattered.

III. Teleutosori hypophyllous, oblong to oblong-linear, prominent, soon naked, dark brown, ruptured epidermis noticeable; teleutospores oblong or clavate-oblon , $16-22$ by $48-56 \mu$; apex rounded, greatly thickened; pedicel slender, colored, half the length of the spore.

On Aster paniculatus Lam., Aster cordifolius L. and Carex foenea Willd. The latter collected at Decorah, Iowa, Dec. 30, 1900 by E. W. D. Holway, and at Lafayette, Ind., April 30, 1901, by the writer.

The common aecidium, found on many species of Aster, is probably included in this species, but not the aecidia found on Erigeron, Solidago or Geranium. It is the same as Aecidium asterum Schw. The uredospores and teleutospores are very similar to those of the preceding species, and are suggestive of biological species. Much work, however, must be done before an approximately accurate statement can be made regarding the Carex species having aecidia upon Compositae. Data for the present separation was obtained as follows:

April 25, teleutospores from Carex foenea (Iowa) sown on Erigeron annuus; no infection.

April 29, teleutospores from C. foenea (Iowa) sown on Erigeron annuus; no infection.

May 4, teleutospores from C. foenea (Indiana) sown on Aster paniculatus; May 13, spermogonia; May 22, aecidia.

May 4, teleutospores from C. foenea (Indiana) sown on Erigeron annuus; no infection.

May 11, teleutospores from C. foenea (Indiana) sown on Geranium maculatum; no infection. 
May 11, teleutospores from C. foenea (Iowa) sown on Erigeron annuus; no infection.

May 13, teleutospores from C. foenea (Iowa) sown on Aster paniculatus; May 20, spermogonia; May 28, aecidia.

May 13, Teleutospores from C. foenea (Iowa) sown on Solidago canadensis; no infection.

May 13, teleutospores from C. foenea (Indiana) sown on Aster cordifolius; May 23, spermogonia; May 30, aecidia.

May 13, teleutospores from C. foenea (Indiana) sown on Solidago canadensis; no infection.

\section{Puccinia bolleyana Sacc.}

This species is first mentioned in the Amer. Mo. Micr. Journal for 1889 (10:I69), with an illustration but no description. It was first described in Saccardo's Sylloge $(9: 303)$, two. years later. It was collected originally on a sterile sedge, presumably a Carex, growing from two to four feet high. The type locality is within two miles of Lafayette, Ind., and only an area ten or fifteen feet across supports the sedge, but almost every leaf over this area has been thickly covered with the rust each season since its discovery. Last year it was found in another locality about four miles distant. It has not been reported from any other place in this or other states, but a specimen sent from Kenosha county, Wisconsin, by Dr. J. J. Davis has proved to be this species. The species is especially characterized by the large teleutospores, and the brown, fusiform uredospores. Within the last month a fruiting specimen of the host has been found upon the type area, which shows it to be Carex trichocarpa Muhl. This in brief is the history of the rust up to the time of making the following cultures. Whether the aecidium, which has been found to grow on Sambucus canadensis, is the wide-spread Aecidium sambuci Schw., or not, it would be premature to say.

May 2, teleutospores from Carex trichocarpa sown on Sambucus canadensis; May 10, spermogonia; May 22, aecidia.

May 3, teleutospores from C. trichocarpa sown on Xanthium canadense; no infection.

May 3, teleutospores from C. trichocarpa sown on Impatiens aurea; no infection.

June 15 , aecidiospores from Sambucus canadensis sown by $\mathrm{Wm}$. Stuart on Carex trichocarpa; July 16, abundant uredospores first noticed, but probably not the first sori to appear.

\section{SUMMARY.}

During I900 and I90I the life cycle of the following eight species of rusts was demonstrated by cultures. Of these successful cultures, the first four have been previously reported, while the cycle of the second four is here reported for the first time. 
I. Uromyces euphorbiae C. \& P. and Aecidium euphorbiae Amer. Auct. with sowings of aecidiospores and uredospores.

2. Puccinia caricis (Schum.) Reb. and Aecidium urticae Schum. with sowings of teleutospores.

3. Puccinia angustata Pk. and Aecidium lycopi Ger. with sowings of teleutospores.

4. Puccinia poculiformis (Jacq.) Wettst. and Aecidium berberidis Pers. with sowings of teleutospores.

5. Puccinia albiperidia Arth. and Aecidium albiperidium Arth. with sowings of teleutospores.

6. Puccinia CARicis-erigerontis Arth. and Aecidium erigeronatum Schw. with sowings of teleutospores.

7. Puccinia caricis-asteris Arth. and Aecidium asterum Schw. with sowings of teleutospores.

8. Puccinia bolleyana Sacc. and Aecidium sambuci Schw. (?), with sowings of teleutospores and aecidiospores.

Purdue Unizersity, Lafayette, Ind., June, 1902. 


\section{CULTURES OF UREDINEAE IN 1902.}

J. C ARTHUR.

THE present article forms the third of a serics of reports by the author upon the cultures of plant rusts. The first one ${ }^{2}$ covered the year 1899 , the second ${ }^{3}$ combined the years 1900 and I90I, and the third covers the year I902. Like the preceding ones, the present report is devoted largely to the heteroecious grass and sedge rusts. The methods employed have already been described in connection with the previous reports.

The work was much more extended during the present season than had been possible in preceding years through the interest taken in it by the authorities of Purdue University, who generously defrayed the expense of additional assistance during the months of May and June, when the largest part of the work must be done. In this way it became possible to have the help for a time of Mr. Oliver P. Terry, an undergraduate of the university, and an unusually skilful manipulator. But the larger part of the testing with drop cultures and of the application of the spores to the plants throughout the whole of the busiest period was undertaken by Miss Julia Titus Emerson, of New York City, coming from the New York Botanical Garden, who showed great earnestness and rare judgment in carrying on the work.

During the present season I 23 collections of material were employed, and 314 drop cultures were made from them to test the germinating condition of the spores. Out of these 23 collections refused to germinate, and were consequently useless. There were in all 327 plant cultures attempted, representing 43 species of rusts, and employing 102 species of hosts tempo-

${ }^{1}$ Read before the Botanical Society of America, Washington, Jan. I, I903.

${ }^{2}$ Bот, Gaz. 29 : 268-276. April I900.

3 Jour. Mycology 8 : 5I-56. June 1902. 
rarily grown in pots in the greenhouse. In no case was success attained where definite clues derived from field observations were lacking.

Fourteen species were tried this year by the guessing method, no clues being known, and the following is a record of the failures, together with one instance, that of the Panicularia rust, where a seeming clue also failed. Teleutospores were employed in every case.

I. Melampsora from Populus delioides Marsh. was sown on Larix europaea, Abies balsamea, Euonymus obovatus, Stylophorum diphyllum, Helianthus strumosus, and $H$. grosse-serratus, with no infection.

2. Melampsora on Salix discolor Muhl. was sown on Larix europaea, Abies balsamea, Picea canadensis, Euonymus obovatus, Ribes aureum, R. gracilis, and Helianthus grosse-serratus, with no infection.

3. UROMYCES Junci Tul. from Funcus tenuis Willd, was sown on Iris versicolor, with no infection.

4. Uromyces Sporoboli E. \& E. from Sporobolus longifolius (Torr.) Wood was sown on Ceanothus americanus and Verbena stricta, with no infection.

5. Uromyces Halstedi De T. from Homalocenchrus virginicus (Willd.) Britt. was sown on Senecio obovatus and Bidens frondosa, with no infection.

6. Puccinia Eleocharidis Arth. from Eleocharis palustris (L.) R. \& S. was sown on Iris versicolor, with no infection.

7. Puccinia Schedonnardi K. \& S. from Schedonnardus paniculatus (Nutt.) Trel. was sown on Lepidium apetalum, Ceanothus americanus, Oxalis cymosa, Apocynum cannabinum, Cassia chamaecrista, Symphoricarpos racemosus, Xanthium canadense, Kuhnistera purpurea, and Lacinaria scariosa, with no infection.

8. Puccinia Muhlenbergiae A. \& H. from Muhlenbergia racemosa (Mx.) B. S. P. was sown on Napaea dioica, Impatiens aurea, Oxalis cymosa, Anemone canadensis and A. virginiana, Hydrophyllum appendiculatum, Phlox divaricata, Physalodes Physalodes, Apocynum cannabinum, and Helianthus grosse-serratus, with no infection. 
9. Puccinia Chloridis Speg. from Chloris verticillata Nutt. was sown on Quamasia hyacinthina, with no infection.

io. Puccinia Sporoboli Arth. from Sporobolus heterolepis Gray was sown on Isopynum biternatum, Oxalis cymosa, Xanthoxylum americanum, Ribes Cynosbati, Cassia Chamaecrista, Symphoricarpos racemosus, Verbena urticifolia, Senecio obovatus, Solidago rigida, Helianthus Maximiliani, Boltonia asteroides, and Brauneria purpurea with no infection.

i I. Puccinia purpurea Cke. from Tripsacum dactyloides L. was sown on Zea Mays, with no infection.

12. Puccinia Stipae Arth. from Stipa spartea Trin. was sown on Aesculus glabra, Cassia Chamaecrista, Psoralea Onobrychis, Symphoricarpos racemosus, Hydrophyllum appendiculatum, Xanthium canadense, Boltonia asteroides, Lacinaria scariosa, and Brauneria purpurea, with no infection.

I3. Puccinia Paniculariae Arth. from Panicularia americana (Torr.) MacM. was sown on Boltonia asteroides, with no infection, although three sowings were made at different dates and with all conditions apparently favorable. This seems to contradict the inference of the writer drawn from field observations (Bull. Torr. Bot. Club 28: 664).

14. Puccinia emaculata Schw. from Panicum capillare L. was sown on Impatiens aurea, Lactuca canadensis, and Eupatorium perfoliatum, with no infection.

I 5. Puccinia Polygoni-amphibil Pers. from Polygonum emersum (Mx.) Britt. was sown on Polygonum pennsylvanicum and $P$. virginianum, with no infection.

Twelve species of rusts were successfully grown, that have been studied with success before, and reported upon by the writer and others. They are enumerated here by way of confirmation, and also in some cases because additional hosts are included. The list is as follows :

I. Uromyces Euphorbiae C. and P.-June I9, aecidiospores from Euphorbia humistrata Engelm. were sown on the same host, and were followed by uredo on July 8 , and also on E. nutans and E. marginata, with no infection. July II, aecidiospores from 
E. nutans Lag. were sown on the same host, and were followed by uredo on July $2 \mathrm{I}$, and also on E. humistrata and E. marginata, with no infection. July 22, uredospores from E. dentata Michx, were sown on the same host, and were followed by uredo on Aug. I 4, and also on E. humistrata, E. nutans, and E. mu.rginata, with no infection. These results, taken in connection with those previously obtained by the writer, ${ }^{4}$ leave no opportunity for doubt that the Euphorbia rust is separable into a number of well established races, or possibly into true species.

2. UREDo RUBIGo-vera DC.-May 3I, uredospores from Triticum vulgare Vill. were sown on Triticum vulgare, and produced uredo on June 13, and at the same time on Hordeum jubatum, Poa compressa, Dactylis glomerata, and Bromus ciliatus, with no infection.

3. Puccinia Peckil (De T.) Kellerm. - The connection of a Puccinia on Carex trichocarpa Muhl. and Aecidium Peckii De T. on Onagra biennis (L.) Scop. (Oenothera biennis L.) has already been reported by Kellerman, ${ }^{5}$ and it was due to the suggestion from Professor Kellerman, founded upon his field observations, that the writer succeeded in bringing the present season's work to a satisfactory issue. ${ }^{6}$ Eleven collections of teleutospores were used: two from Ohio, sent by Professor Kellerman; two from Racine, Wisconsin, sent by Dr. J. J. Davis; two from Spirit Lake, Iowa, obtained by the writer; and the remainder from different localities near Lafayette, Indiana. Seven of these collections were definitely known to be on Carex tricho. carpa, and four of them, those from Wisconsin and Iowa, were presumably on that host.

Spores from these collections were sown on Urtica gracilis, Anemone canadensis, Geranium maculatum, Impaticns aurea, Sambucus canadensis, Ribes gracile, R. Cynosbati and R. floridum, Xanthium canadense, Aster Shortii and A. paniculatus, Solidago canadensis, Erigeron annuus, and Leptilon canadensis, with no infection. Successful cultures on Onagra biennis were made as follows, the

4 Bот. GAz. 29:271. I900, and Jour. Mycology 8:51. 1902.

5 Jour. Mycology 8:20. 1902 .

${ }^{6}$ For record of previous failures see Jour. Mycology 8: 52. 1902. 
period between the sowing of the dry spores and the appearance of the spermogonia varying from five to seven days, and between the appearance of the spermogonia and the appearance of the aecidia an equal length of time, the two intervals making ten to thirteen days.

Cultures of Puccinia from Carex trichocarpa ON ONAGRA BIENNIS.

\begin{tabular}{|c|c|c|}
\hline $\begin{array}{c}\text { Teleutospores } \\
\text { sown }\end{array}$ & $\begin{array}{c}\text { Spermogonia } \\
\text { appeared }\end{array}$ & $\begin{array}{l}\text { Eccidia } \\
\text { appearec }\end{array}$ \\
\hline April 26 & May I & May \\
\hline May 2 & May 8 & May $\mathbf{I}$ \\
\hline May & May & May I \\
\hline May 2 & May 9 & May I \\
\hline May & May Io & May I \\
\hline May & May 12 & May is \\
\hline May & May 13 & May Io \\
\hline May & May I4 & May is \\
\hline May & May I4 & May I \\
\hline May & May 15 & May 2 \\
\hline May 27 & June 2 & June \\
\hline May 28 & June & June \\
\hline May 29 & June & June \\
\hline
\end{tabular}

A collection on Carex stipata Muhl. also was made near Lafayette, Indiana, spores from which were sown on Ribes Cynosbati, R. floridum, R. Uva-crispa, Aster paniculatus, A. prenanthoides, Solidago canadensis, and $S$. serotina, with no infection. It was not until aecidia were found in the field on seedlings of Onagra biennis, growing close to the Carex still bearing dead leaves covered with teleutospores, that the right plant was selected for cultures. Teleutospores were sown on Onagra biennis June 23; spermogonia appeared in great abundance July I, and aecidia July 8.

4. Puccinia Bolleyana Sacc. and P. Atrinsoniana Diet.The connection of Puccinia Bolleyana, which occurs on Carex trichocarpa Muhl., with Aecidium Sambuci Schw. has already bcen reported by the writer. ${ }^{7}$ This has been confirmed by further successful trials. Material gathered from the type locality of $P$. Bolleyana, when examined under the microscope, was found to show only a small proportion of the characteristic spores of

7 Jour. Myc. 8: 55 . 
this species, and a large proportion of much smaller spores, which were surmised to belong to Puccinia Peckii. Sowings were made, May 5, on Sambucus canadensis and Onagra biennis. May I0, abundant spermogonia appeared on Onagra, followed May 16 by aecidia. On Sambucus spermogonia appeared sparingly May 13, followed by aecidia May 21. The sedge, therefore, bore two species of rust in 1901 , intermixed on the same leaves. In addition to this, on May 19, aecidiospores from Sambucus canadensis were sown on Carex trichocarpa, which gave rise to uredo on May 27. The connection of Puccinia Bolleyana with Aecidium Sambuci appears to be proven beyond question.

Two collections of Puccinia Atkinsoniana on Carex lurida Wahl. were sent from Columbus, Ohio, by Professor Kellerman, with the suggestion, which seemed to me at the time very improbable, that the aecidia doubtless occurred on Sambucus canadensis. Another collection was secured from the vicinity of Lafayette, Indiana. Two sowings were made on Onagra biennis without infection. One sowing from each of the three collections was made on Sambucus canadcnsis with abundant success in each case. The dates are respectively April 28, May 7 and 16 ; April 29, May 5 and I6; and May 7, I2, and 21. Professor Kellerman has written me that his cultures also gave similar results.

These discoveries led to a careful microscopic study of the two Carex rusts, and there appears to be no reason to question that $P$. Atkinsoniana and $P$. Bolleyana are identical. In the designation of the species it seems necessary on grounds of priority to abandon both these names, however, and it becomes Puccinia Sambuci (Schw.), nom. nov.

5. Puccinia Caricis-Asteris Arth.-A collection of this species on Carex foenea Willd. was sown on Solidago serotina, with no infection. It was also sown, May 2, on Aster paniculatus Lam., and was followed by spermogonia May 8, and aecidia May 19, thus confirming the writer's previous work. ${ }^{8}$

6. Puccinia Caricis-Erigerontis Arth.-A collection of this rust on Carex festucacea Willd. was used for cultures on Erigeron

${ }^{8}$ Jour. Mycology 8: 54. 1902. 
annuus (L.) Pers., E. philadelphicus L., and Leptilon canadense (L.) Britt., with the most unqualified success. The work of last year' is thus confirmed, and additional hosts ascertained.

7. Puccinia Caricis (Schum.) Reb. - A collection of this rust on Carex stricta Lam., sent by Rev. J. M. Bates from Callaway, Nebraska, gave rise to aecidia when sown on Urtica gracilis Ait., the dates for sowing, appearance of spermogonia and aecidia being respectively May 24, June 2 and 7 . The experimental proof of this connection has been reported ${ }^{\text {to }}$ twice previously for American material. A collection sent by Mr. E. W. D. Holway from Decorah, Iowa, on Carex riparia Curt. was sown on Ribes Cynosbati, $R$. gracile, $R$. aureum, $R$. floridum, and $R$. Uva-crispa, Geranium maculatum, Onagra biennis, Sambucus canadensis, and Xanthium canadense, with no infection. It was sown on Urtica gracilis May 21, and gave spermogonia May 27, and aecidia June 2.

8. Puccinia Vilfae A. \& H.-The alternate form of this rust has been show ${ }^{I I}$ to be Aecidium verbenicola K. \& S. These results have been verified this season by sowing teleutospores from Sporobolus longifolius (Torr.) Wood, collected at Callaway, Nebraska, by Rev. J. M. Bates, on Verbena stricta Vent. (culture dates May 28, June 3 and IO) and on $V$. urticifolia L. (culture dates the same). A collection from Lafayette, Indiana, on the same host, was also sown on $V$. urticifolia with success (culture dates May 2, I0, and 19). To conform to present knowledge the name of the rust should be written Puccinia verbenicola ( $K$. \& S.), nom. nov.

9. Puccinia Windsoriae Schw.-A collection of the teleutospores of this species of rust on Tricuspis seslerioides Torr. (Triodia cuprea Jacq.) was sent from Denton, Texas, by Mr. W. H. Long, Jr., with the statement that Aecidium Pteleae B. \&. C., which has been taken to the alternate form of the rust, ${ }^{\mathrm{x} 2}$ had not been observed in that vicinity. This material was sown on Ptelea trifoliata L., May 9, and spermogonia appeared May I 5, followed by abundant aecidia May 24 .

9Jour. Mycology 8:54. 1902.

${ }^{20}$ Bot. GAz, 29:279. 1900, and Jour. Mycology 8:52. 1902.

"BОT. GAZ. 29 : 274. 1900.

"Вот, GAz. 29:273. 1900. 
io. Puccinia Helianthi Schw.-Cultures showing this species to be autoecious have heretofore been made with American material only by Carleton's, but have been reported from Europe. Teleutospores gathered in this vicinity on Helianthus grosse-serratus Mart. were sown on the same species of host with success (culture dates May 8, I 7, and 23) and also on H. Maximiliani Schrad. (culture dates May 8, I6, and 22), but sowings at two different dates on $H$. strumosus gave no infection. This evidence of races, so far as it goes, does not accord with Carleton's opinion that "there is no distinction of host forms."

i I. Phragmidium speciosum Fr.-A successful culture ${ }^{14}$ of this species of rust was again tried, using teleutospores from a hardy garden rose, obtained at Spirit Lake, Iowa, and sowing them on Rosa humilis Marsh. The culture was made April 24, and vigorous spermogonia appeared May 3, but the leaves gradually withered without the formation of the aecidial stage.

Beside the foregoing negative and confirmatory results, successful cultures were made establishing aecidial and teleutosporic association, heretofore unknown, for seven species of heteroecious grass and sedge rusts.

1. Uromyces Aristidae E. \& E.-The material for the study of this species was received from Mr. W. H. Long, Jr., who suggested that its aecidial form was to be looked for on various species of Plantago. Teleutospores on Aristida oligantha Michx. were collected the middle of March, at Denton, Texas. Sowings were made from this material on Plantago Rugelii Dec., May 2, from which spermogonia arose May I 3, and aecidia May 20. The development was not luxuriant, but very characteristic. A sowing on the same date on P. lanceolata, and later sowings on both species gave no infection. It would seem that these two species of Plantago are less suited to the ready development of the species than other members of the genus. The middle of April I received from Mr. Long freshly gathered aecidia on Plantago virginica L., and on two undetermined species, which are doubt-

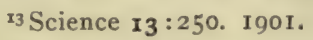

14 For previous record see Bot. Gaz. $29: 27$ I. 1900. 
less P. Purshii R. \& S. and P. aristata Michx. I also have it in my herbarium on $P$. virginica from Illinois (Ellis and Everhart's N. Amer. Fungi, no. 1829), on P. Purshii from Nebraska (Fungi Columbiani, no. 1475), and on P. eriopoda Torr. from Montana, collected by F. D. Kelsey. The aecidium has passed under the name of $A$. Plantaginis Ces., but the identity with the European form needs verification, although microscopically the two are very similar.

2. Puccinia Bartholomaei Diet.-Again I am indebted to Mr. W. H. Long, Jr., for material and suggestions leading to the discovery of the aecidial connection of this host. Under date of April 8, 1902, he wrote: "I have never found Puccinia vexans in the state, although it is reported from Texas; $P$. Bartholomaei I have found, also its aecidial stage, which is Aecid. Jamesianum on Asclepiodora decumbens. I have never found this milkweed with aecidia on it, that I did not find teleutospores of $P$. Bartholomaer thickly covering the leaves of Bouteloua curtipendula around and under the milkweed, and the teleutospores when examined had germinated. Later the young grass in and near the bunches of infected milkweed would first show the rust; and where no teleutospores were found under or near the milkweed no aecidia were seen. This I observed repeatedly in my field work last year."

Mr. Long sent teleutospores on Atheropogon curtipendulus Fourn. (Bouteloua curtipendula Torr.), which were sown on Asclepias incarnata L. on May 2, giving rise to spermogonia May 8 , and aecidia May I7. They were later sown with success on the same host (culture dates, May 2I, 28, and June 5), and on Asclepias syriaca L. (culture dates, May I2, 18, and 26). They were also sown at two different dates on Apocynum cannabinum, with no infection.

As the specific name of the aecidium is older than that of the teleutosporic stage, the name of the fungus should become Puccinia Jamesiana ( $\mathrm{Pk}$.), nom. nov.

3. Afecidium Impatientis Schw.-The aecidium on Impatiens, and there appears to be but one, is very common throughout the eastern United States. It often occurs in a locality in the great- 
est abundance, frequently affecting the leaves and stems of nearly every plant in a large area where the host may be growing thickly. Such a group of plants has been under observation for a number of seasons. In a space some twenty feet across, protected by a group of willows, many hundreds of Impatiens aurea Muhl. have sprung up from seeds each succeeding spring, and when from six inches to a foot high have become remarkably infested with aecidia. A rather large number of grass and sedge rusts occur in the vicinity of this spot, and the teleutospores of these have been sown in succession on Impatiens, and invariably with no infection. It was not until well into June of the present year that any clue was obtained. A tuf ${ }^{2}$. of Elymus virginicus L., growing at the edge of this patch of infested Impatiens, was found to possess young sori of some uredo. Searching further, dead leaves of the previous season were obtained bearing inconspicuous sori of what has generally been called Puccinia rubigo-vera, the teleutospores of which had already germinated. A collection on the same host was in the laboratory. however, that had been obtained early in the season from a locality some miles distant, which was still in germinating condition. Teleutospores from this were sown on Impatiens aurea, June I0, spermogonia following abundantly June I7, and accidia June 25. Spores from the same collection had been sown previously on Ambrosia trifida and Napaea dioica, with no infection.

There are other creditable species of Puccinia on Elymus in the Rocky mountain and Pacific states, but this is the most common species and possibly the only one in the eastern states. It should be called Puccinia Impatientis ( $\mathrm{Sch} w$.$) , nom. nov.$

4. Puccinia subnitens Diet.-I am indebted to Rev. J. M. Bates, of Callaway, Nebraska, for material to make the cultural study of this species, and for the suggestion which made the study fruitful. He wrote that wherever the grass rust occurred he had observed an aecidium on Chenopodium leptophyllum (Moq.) Nutt.

Teleutospores from Distichlis spicata (L.) Greene were sown on Chenopodium album L. on May 24, and on May 3 I spermogonia appeared in the greatest luxuriance, followed by aecidia on June 
3. A second sowing was made May 27, with spermogonia June 3 , and aecidia June 9, in equal abundance. The crumpling of the leaves by the aecidia, and their bright orange color, made these the most striking cultures of the season. This aecidium is undoubtedly $A$. Ellisii $\operatorname{Tr}$. \& Gall., founded on a collection from New Mexico.

5. Puccinia amphigena Diet.-In the year 1883 the type collection for this species was made by the writer at Ravenswood, now a part of Chicago. The same season an aecidium was found on Smilax herbacea in the immediate vicinity, ${ }^{15}$ which appeared to be $A$. Smilacis Schw. Owing to the limited distribution of these two forms, and their association within a seemingly restricted area, their possible genetic connection was thought worth testing. This opinion was strengthened by the fact that the grass rust has been collected a number of times since by the writer in the same locality, but no other aecidium has been found there at all likely to belong to it.

Teleutospores on Calamovilfa longifolia (Hook.) Hack., kindly sent by Rev. J. M. Bates from Callaway, Nebraska, were sown May I 3 on both Smilax herbacea L, and S. hispida Muhl., and on May 20 both showed spermogonia, and May 3 I aecidia. A second sowing on May 27 was only partially successful, as the leaves prematurely withered.

6. Puccinia simillima Arth.-At the time of the publication of this species the writer called attention ${ }^{16}$ to its probable connection with an aecidium on Anemone canadensis, which occurred in great abundance in the immediate vicinity.

Teleutospores on Phragmites Phragmites (L.) Karst. (P. communis Trin.), obtained by the writer from the type locality at Spirit Lake, Iowa, were sown on Anemone canadensis L., May I, producing spermogonia May 5, and aecidia May I3. They were also sown, partly at the same time and partly later, on Anemone cylindrica, A virginiana, Pulsatilla hirsutissima, and Ranunculus septentrionalis, all seemingly reasonable hosts, but with no infection. The aecidium has passed for Aecid. Ranunculacearum, but whether

${ }^{25}$ See Burrill, Parasitic Fungi of Illinois 238.

${ }^{86}$ Вот GAz. 34: 18. 1902. 
it is distinct or not from the similar aecidia which have been found on the other hosts mentioned cannot now be stated.

7. Aecidium Solidaginis Schw.-Having found Puccinia teleutospores on Carex Jamesii Schw., they were sown on four species of Ribes, with no infection. They were then sown on six species of Aster, with no infection. At about the same time, May 9, they were sown on Solidago canadensis L., and followed by spermogonia May I5, and aecidia May 22. On May 24 a sowing was again made on S. canadensis, and also on S. ulmifolia Muhl., S. caesia L., S. rigida L., and S. serotina Ait., all of which produced spermogonia in ten to twelve days, but only the last developed aecidia. Part of these trials were repeated, and sowings also made on three additional species of Solidago, but without success. These failures appear to have been due chiefly to the feeble condition of the host plants.

A collection of Puccinia on Carex stipata Muhl., sent by Mr. E. W. D. Holway from Decorah, Iowa, was used for cultures on four species of Ribes, and on Erigeron annuus and Onagra biennis, with no infection. Afterward it was tried, May 27, on Solidago canadensis, giving spermogonia June 2 and aecidia June 9. On the same date it was sown on S. serotina, giving spermogonia June 2 and aecidia June Ir.

As the specific name Solidaginis is already employed in the genus Puccinia, I propose for this species the name of Puccinia Caricis-Solidaginis. A comparison of this species with $P$. CaricisAsteris and $P$. Caricis-Erigerontis shows many resemblances, and it seems not improbable that the three represent more correctly the biological variations of one species. However, in the many cultures so far made no set of teleutospores has been found that would infect more than one of the three host genera, Aster, Erigeron, and Solidago.

\section{SUMMAKY.}

The following is a complete list of successful cultures made during the season of 1902 . It is divided into the two series: species previously reported by the writer or other investigators, and species now reported for the first time. 


\section{A. Species previously reported.}

I. Uromyces Euphorbiae C. \& P.-Aecidiospores from Euphor. bia humistrata Engelm, sown on same host. Aecidiospores from $E$. nutans Lag. sown on same host. Uredospores from $E$. dentata Michx. sown on same host.

2. UREDO RUBIGO-VERA DC.-Uredospores from Triticum vulgare Vill. sown on same host.

3. Puccinia Peckin (De T.) Kellerm.-Teleutospores from Carex trichocarpa Muhl. and C. stipata Muhl. sown on Onagra biennis (L.) Scop.

4. Puccinia Sambuci (Schw.) Arth.-Teleutospores from Carex trichocarpa Muhl. and C. lurida Wahl. sown on Sambucus canadensis L., and aecidiospores from S. canadensis L. sown on C. trichocarpa Muhl.

5. Puccinia Caricis-Asteris Arth.-Teleutospores from Carex foenea Willd. sown on Aster paniculatus Lam.

6. Puccinia Caricis-Erigerontis Arth.-Teleutospores from Carex festucacea Willd. sown on Erigeron annuus (L.) Pers., E. philadelphicus L., and Leptilon canadense (L.) Britt.

7. Puccinia Caricis (Schum.) Reb.-Teleutospores from Carex stricta Lam. and C. riparia Curt. sown on Urtica gracilis Ait.

8. Puccinia verbenicola (K. \& S.) Arth.-Teleutospores from Sporobolus longifolius (Torr.) Wood sown on Verbena stricta Vent. and $V$. urticifolia L.

9. Puccinia Windsoriae Schw.-Teleutospores from Tricuspis seslerioides (Michx.) Torr. sown on Ptelea trifoliata L.

io. Puccinia Helianthi Schw.-Teleutospores from Helianthus grosse-serratus Mart. sown on same host, and on H. Maximiliani Schrad.

i i. Phragmidium speciosum Fr.-Teleutospores from cultivated rose sown on Rosa humilis Marsh.

B. Species reported now for the first time.

I. Uromyces Aristidae E. \& E.-Teleutospores from Aristida oligantha Michx. sown on Plantago Rugelii Dec.

2. Puccinia Jamesiana (Pk.) Arth.-Teleutospores from Atheropogon curtipendulus (Michx.) Fourn. sown on Asclepias incarnata L. and $A$. syriaca $\mathrm{L}$. 
3. Puccinia Impatientis (Schw.) Arth.-Teleutospores from Elymus virginicus L. sown on Impatiens aurea Muhl.

4. Puccinia subnitens Diet.-Teleutospores from Distichlis spicata (L.) Greene sown on Chenopodium album L.

5. Puccinia amphigena Diet.-Teleutospores from Calamovilfa longifolia (Hook.) Hack. sown on Smilax herbacea L. and S. hispida Muhl.

6. Puccinia simillima Arth.-Teleutospores from Phragmites Phragmites (L.) Karst. sown on Anemone canadensis L.

7. Puccinia Caricis-Solidaginis Arth.-Teleutospores from Carex Jamesii Schw. and C. stipata Muhl. sown on Solidago canadensis L. and S. serotina Ait., and also from the former Carex host sown on S. caesia L., S. ulmifolia Muhl. and S. rigida L.

It will not be out of place to emphasize again the desirability of making field observations upon the association of aecidial, uredo, and teleutosporic forms within small areas. There is little chance for progress in establishing the connection of spore-forms through cultural work, except by acting upon the hints derived from field notes. Any acute observer is likely to be able to make one or more important deductions of this kind during a season, which may lead to valuable discoveries upon testing by cultures. If collectors would bear the matter in mind, the perplexing tangle of our knowledge of the heteroecious rusts would soon largely yield to experimental study.

I cannot too heartily express my appreciation of the kindness of Professor W. A. Kellerman, Mr. W. H. Long, Jr., Rev. J. M. Bates, Dr. J. J. Davis, and Mr. E. W. D. Holway, for their assistance with material, and especially with suggestions derived from their field observat ons. Without such help much of the work recorded in this report could not have been undertaken.

Purdue University, Lafayette, Ind. 



\section{CULTURES OF UREDINEAE IN 1903.}

J. C. ARTHUR. 


\section{CULTURES OF UREDINEAE IN 1903. ${ }^{1}$}

J. C. ARTHUR.

The present article forms the fourth of a series of reports ${ }^{2}$ by the author upon the cultures of plant rusts. They cover the years from 1899 to the present inclusive. This report is devoted both to autoecious and heteroecious species, among which the grass and sedge rusts have had a prominent place. The number of species studied and the number of cultures made have fallen off somewhat from.last year, partly because it was late in the spring before assistance was secured to carry on the work, and partly because a less number of collections of teleutospores and field observations were obtained upon which to base the work. The results however, fully equal in interest and importance those of last year, or possibly exceed them.

The expense of additional assistance in carrying on the work, and to some extent the expense of procuring material, was 30, 1903 .

${ }^{1}$ Read before the Botanical Society of America, St, Louis, December $35: 10-23$.

See Bot. Gaz. 29:268-276; Jour. Mycol. 8:51-56; and Bot. Gaz. 
borne this year in part by the Indiana Experiment Station and in part by a grant from the Botanical Society of America. By this means I was enabled to have the services of Mr. J. Clyde Marquis, an unclergraduate student of the university, who made part of the preliminary drop cultures and attended to the microscopical technique, and of Mr. Fred J. Seaver, a graduate of Morningside College, Sioux City, Iowa, and a fellow in botany at the University of Iowa, who made most of the sowings and drop cultures and kept the records. The most active period for this work extends from the middle of April to the middle of June, while a smaller portion of the work extends through the remaining months of the year: The grant from the Botanical Society also permitted systematic field observations at Fair Oaks in the oak barrens of northern Indiana, where many species of rusts abound, for the most part unlike those occurring at Lafarette where the chief field observations heretofore necessarily have been made. These excursions into an unworked locality resulted in the discovery of the Andropogon-Comandra combination, the undescribed Carex-Solidago combination, and the autoecious character of the wide-spread Lespedeza rust, as well as minor items.

During the present season 68 collections of material were employed, and 2I7 drop cultures were made from them to test the germinating condition of the spores. Out of these $26 \mathrm{col}-$ lections refused to germinate, and were consequently useless. There were in all 215 sowings of spores made, representing 32 species of rusts, and for this purpose were required 72 species of hosts temporarily grown in pots in the greenhouse. As in previous years success was attained in no case except when definite clues derived from field olservations were in hand.

In order to provide ample resources, as far as possible, so that whatever suggestions are obtained even late in the season can be tested without delay, a stock of teleutosporic material is laid in of any species obtainable. In consequence there are always some species on hand in germinating condition with no definite guide for their use. So far as time permits these are sown upon any hosts known to bear aecidia in the region where the rust abounds. The results so far have been confined wholly to the negative information that the aecidia could not be produced on certain hosts. The following is a record of such blind attempts made during I903. Telentospores were employed in every case.

1. Uromyces actimatus Arth. on Spartina cynosuroides Willd. from Fair Oaks, Ind., was sown' on Hydrophyllum appendiculatum, with no infection.

2. Piccinia Polygoni-animual Pers. on Polygonum cmersum (Michx.) Britt. from Columbus, (Ohio, and Fair Oaks, 
Ind., was sown on the same host and on Cicuta maculata, with no infection. Last year this rust was sown on two other species of Polygonum without infection. Recently the preliminary announcement of rust cultures for the season of 1903 by Dr. W. Tranzschel of St. Petersburg has been published. He states that infection was secured on Geranium, showing that the wiclely distributed Aecidium sanguinolentum Lindl., commonly found on Geranium maculatum in America, is the alternate form of this rust. My own observations in the field all go to affirm the correctness of this result.

3. Puccinia on Carex Pennsylvanica Lam. from Red Cloud, Neb., and Fair Oaks, Ind., was sown on Aster paniculatus, $A$. Drummondii, A. prenanthoides, Solidago rigida, S. canadensis, Xanthium Canadense, Silphium perfoliatum, Ribes Cynosbati, R. aureum, Geranium maculatum, Viola cucullata, and Onagra biennis, with no infection.

4. Puccinia on Carex gravida Bailey from Red Cloud, Neb., was sown on Aster Drummondii, A. paniculatus, Senecio oboz'atus, Boltonia asteroides, Silphium perfoliatum, Ambrosia trifida, Xanthium Canadense, Cleome spinosa, Sambucus Canadensis, Ribes Cynosbati, Xanthoxylum Americanum, and Onagra biennis, with no infection.

5. Puccinia on Elymus Canadensis L. from Red Cloud, Neb., was sown on Impaticns aurea, Symphoricarpos racemosus, and Napaea dioica, with no infection. There are various reasons, of which the above is one, for thinking that the rust on the several species of Elymus, occurring east of the Rocky Mts., which has heretofore been referred to one species really belongs to several species.

6. Puccinia vexans Farl. on Boutelona curtipendula (Michx.) Torr. from Red Cloud, Neb., was sown on Cleome spinosa, Physalis heterophylla, Physalodes Physalodes, Cassia Chamaecrista, and Pentstemon hirsutus, with no infection.

7. Peccinia tosta Arth. on Sporobolus neglectus Nash from Red Cloud, Neb., was sown on Oralis cymosa, Ceanothus Americanus, Symphoricarpos racemosus, Cassia Chamaccrista, Callirrhoe involucrata, Xanthoxylum Americanum, Cleome spinost, and Aster ericoides, with no infection.

8. Puccinia emaculata Schw. on Panicum capillare L. from Fair Oaks, Ind., was sown on Aster prenanthoides, $A$. Drummondii. Solidago rigida, Lactuca Canadensis, Eupatorium perfoliatum, Xanthium Canadense, Ambrosia trifida Apocynum cannabinum, Polemonium reptans, Ribes Cynosbati, Onagra biennis, Anemone Pennsylvanica, and Geranium maculatum, with no infection. 
live species of rusts were successfully grown, that had been stuclied with success before, and reported upon by the writer and in part by other invesigators. Mention of them here serves to confirm previous work, and in two cases to give additional knowledge regarding hosts.

I. Peccinia Impatientis (Schw.) Arth-Deleutosporic material of this species on Elymus Virginicus was obtained near Lafayette, Incl., and sown, May 13, on Impatiens aurea. On May 18, an abunclance of spermogonia appeared, and on May 26, an equal abundance of aecidia began to show. This result confirms the work of last year. ${ }^{3}$ The locality from which the teleutosporic material was obtained for this season's work is several miles from the one yielding material last year.

2. Puccinia amphiciena Diet.-Teleutosporic material was obtained by the writer on Calamovilfa longifolia from the type locality at Chicago, I11. A sowing was made on a mature leaf of Similax hispida, Nay 23. Spermogonia appeared sparingly on May 29. hut were not followed by aecidia. Another sowing was maile on a partly grown leaf of the same host species, May 24. from which a great abundance of spermogonia began to appear on May: 28. followed by an equal abundance of aecidia, June 5. Some question has been raised regarding the correctness of last year's work, as the teleutosporic form is known from regions where it is thought that Smilax does not grow, but that the gentine Puccinia amphigena has its alternate form on Smilax can no longer be doubted.

3. l'uccinia Andropogonis Schw.-Teleutosporic material on Andropogon scoparius, collected at Bloomington in southern Velraska, was sent to Rev. J. M. Bates. It was sown on Pentstcmon hirsutus. May 19, giving rise to abundant spermogonia (1) May 25. followed by aecidia on June 4. Previous cultures have been macle by Mr. William Stuart and the writer, ${ }^{5}$ and by Prof. W. A. Kellerman. ${ }^{\circ}$ There can be no question that this is a wirle-spread and common species in North America.

4. Puccinia alibiperidia Arth--Teleutosporic material of this species on Carex gracillima was most opportunely sent from Racine. Wis., by Dr. J. J. Davis. Sowing was made April 2I, on Ribes Cynosbati, from which abundant spermogonia appeared on April 30, followed by great numbers of aecidia on May ir. A sowing made at the same time on $R$. floridum gave no infection. Three lays later a sowing made on $R$. aureuin seemed to have marle a slight growth. which, nevertheless, came to naught. A sowing on $R$. Ii $\varepsilon^{\prime}(l-c r i s p a$, a cut branch being placed in a glass of

${ }^{8}$ Bot. Gaz. $35: 18.1903$.

- Bot. Gaz. 35 :20. 1903.

s Bot. Gaz. $20: 272.1900$.

- Jour. Mycol. 9:10. 1903. 
water in the laboratory in lieu of a potted plant, gave some spermogonia, but the leaf fell from the stem before the time for the appearance of the aecidia. It would have undoubtedly been a successful infection, had the conditions been favorable for maintaining the vigor of the host. This species is based upon cultures marle by the writer in 190I. Its exact standing is yet in some uncertainty, and probably can not be settled until the connection of the very common aecidium, or aecidia if more than one kincl, on the several species of Ribes is ascertained. Dr. J. $J$. Davis ${ }^{*}$ has expresed the opinion that the whiteness of the aecidial cups is probably due to the conditions under which they are grown, and that they are normally orange-colored and identical with the common form. But the facts can only be ascertained by cultural studies.

5. P'uccinia Helianthi Schw.-Ample teleutosporic material was available in vigorous germinating condition, collected by I'rof. W. A. Kellerman at Sandusky, Ohio, and by the writer at Fair Oaks, Ind. All of it was on Helianthus mollis. Sowings hegan on April 29, and continued at intervals until June 2, twenty cultures being attempted. The sowings on H. strumosus, 1I. tuberosus, H. grosse-serratus, H. rigidus, and $H$. Maximiliani gave no infection. The sowing on $H$. tomentosus gave a slight infection, a few spermogonia appearing but reaching no firther development, although the leaves were young and the plants exceptionally vigorous. On $H$. mollis and $H$. annuts an exceedingly strong infection was produced, numberless spernogonia appearing, followed by well developed aecidia in great quantity. The first sowings on $H$. mollis were marle May 6 , the first spermogonia appearing May 16 , and the first aecidia May 22 and 23. A second sowing was made May 29, giving spermogonia Jume 7 , and aecidia June 16 . The sowing on $H$. annuns was made June 2, showing spermogonia June 8, and aecidia June i7.

Cultures of the Helianthus-rust were made during the previous year's work, employing spores from $H$. grosse-scrratus, which were found to grow upon the same host and the similar H. Maximiliani, but not upon $H$. strumosus. Judging from the work of the two years, it appears possible to divide the Helianthus-rust into at least three series, for which the forms on $H$. mollis. $H$. strumosus and $H$. grosse-scrratus may be taken as representatives respectively. Dr. E. Jacky ${ }^{10}$ of Switzerland has made cultures, and has come to the conclusion that there are two species of Helianthus-rust, for which the names $P$. Helianthi Schw, and P. helianthorum Schw, are to be used. It seems to

TJour. Mycol. 8:53. 1902.

- Trans. Wis. Acad. Sci. $14: 88.1903$.

- Bot. Gaz. $35: 17.1903$.

${ }^{10}$ Centr. f. Bakt. $9^{2}: 841,1902$. 
me that the data are yet too meager to make it worth while to unclertake to decide upon the nomenclature of the forms or species, which ever they may be called.

In addition to the foregoing results seven species of rusts were grown, establishing aecidial and teleutosporic connections. not heretofore recorded. The species are partly autoecious and partly heteroecious rusts.

I. Melamisori Medusae Thüm.-Teleutosporic material (n) Populus deltoides Marsh. was obtained in the vicinity of Lafayette, Ind., and although of inferior quality, for the poplar rust was not abundant in this region last year, it was sown on Larix decidua Mill. (L. Europaea DC.) April 28. After a rather long interval of I6 days I was surprised and gratified to observe the beginning of spermogonia (May 14) in goorl quantity; and five days later (May I9), the aecidia appeared, and proved to be a caeoma-form. A sowing on this host was tried last year" ${ }^{11}$ without infection, which is, however, easily accounted for by the fact that the host plants employed in 1902 were very feeble. For the supply of Larix, used this vear I am inclebted to the generosity of R. Douglas' Sons, proprietors of the Waukegan Nurseries at Waukegan, Ill. They sent without remuneration 25 very thrifty young larch, suitable for 6-inch pots, which made vigorous growth when brought into the greenhouse.

This species is the American representative of the European M. populina Lèv., both species having their aecidia on Larix. That the American form is specifically distinct from the European was pointed out by Klebahn ${ }^{12}$ in 1899 , the differences being especially marked in the form, size and markings of the uredospores, and in the apical thickening of the teleutospores. The American form may be characterized as follows:

\section{Melampsora Medusae Thuem.}

O. Spermogonia epiphyllous, numerous scattered, inconspicuous, pale yellow, papilliform by vertical sections shown to be columnar or hemnispherical, raised above the surfact, $40-55 \mu$, in diameter.

I. Aecidia hypophyllous, numerous, scattered, small, less than $.5 \mathrm{~mm}$. in diameter, pale yellow: peridium absent; aecidiospores catenulate, globoid, 20 in diameter: wall colorless, nearly $3 \mu$ thick, finely verrucose.

II. Uredospores amphigenous. or sometimes only hypophyllous, roundish, small, less than $.5 \mathrm{~mm}$. in diameter, early naked, somewhat pulverulent, orange yellow; uredospores oval, or obovate-oblong, 15-18 by 2230 ", usually flattened on opposite sides; wall colorless, $2.5-3 \%$, thick, or up in $10 \%$ on the flattened sides, sparsely and evenly echinulate with fine papillae, except on the flattened sides which are smooth; paraphyses

\section{${ }^{11}$ Bot. Gaz. $35: 11$. 1903.}

12 Ztschr. f. Pfl.-Kr. 9:144. 1899. 
usually numerous, peripheral, capitate, smooth, 40-50 $\mu$ long, head 14-20 $\mu$ broad.

III. Teleutosori amphigenous, or sometimes only hypophyllous, small, irregularly roundish and scattered, or somewhat coalescing, subepidermal, at first light reddish brown, becoming deep chocolate-brown; teleutospores prismatic, $12-14$ by $30-44 \mu$, wall smooth, cinnamon-brown, uniformly thin, not thickened at apex.

Spermogonia and aecidia on Larix, but not yet collected. Uredo and teleutospores on Populus deltoides Marsh. (P. Medusae Benth., P. Canadensis Moench., $P$. monilifera Ait., $P$. angulata Ait.), $P$. grandidentata Michx., P. tremuloides Michx.. P. balsamifera L., P. angustifolia Jas., and P. trichocarpa Torr. \& Gr. Common throughout the United States and Canada.

2. Uromyces Phaseoli (Pers.) Wint.-This is a very common rust on various species of Phaseolus, Strophostyles and Vigna. Nevertheless its aecidial form, is rarely seen, and it has been suggested that the American form might be heteroecious. Material for the cultures was collected near Lafayette, on Strophostyles helvola (L.) Britt. (Phaseolus diversifolius Pers.). It was sown, May I, on Euphorbia commutata Engelm., with no infection. On May I5, a sowing was made on Strophostyles helvola, which gave abundant spermogonia on May 26, and well developed aecidia began to appear on June 4. Five subsequent sowings were made, but owing to difficulty in keeping the hostplants in flourishing condition only two of these gave positive results, and even these were less abundant than in the first trial. The autoecious character of the American form, however, is well demonstrated. It should be said that the somewhat common aecidium on Apios and Amphicarpa holds a doubtful relation to the bean rust, and is better considered distinct until positive relationship is established.

3. Lromyces Lespedezae-procumbentis (Schw.) Curt. This is a wide spread, and often abundant rust, occurring on various species of Lespedeza. No aecidium has ever been found clearly associated with it. The small and inconspicuous Aecidium leucospermum B. \& C., rarely collected, has been suggested as a possible alternate form, but not very confidently.

Excellent teleutosporic material was obtained by the writer at Fair Oaks, Ind., in March, on the upright stems of Lespedead capitata Michx. It was not until late in May that a host-plant was well established in the greenhouse. A sowing of spores was made on May 28, the host being $L$. capitata. Infection resulted, but the development was slow, clearly due to inferior growth conditions. Un June I4 the first spermogonia protruded, soon becoming exceedingly numerous, and on June 18 , the minute, colorless aecidia began to appear in great numbers. The typical form of Aecidium leucospermum was the result.

4. Puccinia caulicola Tr. \& Gall.-Fine teleutosporic material of this species on the stems of Salvia lanceolata Willd. was 
sent to me in March by Mr. Elam Bartholomew, from Rockipurt. Kans. Seeds of the host were also sent, from which young plants were grown for culture work. A sowing was made on April 27: on May II, the spermogonia began to appear, and on May 18, the aecidia. One later sowing was also successful, but the host plants did not flourish, and the results were meager. The demonstration, however, proved ample to establish the autoecious character of the species.

The aecidium of this species is so rarely seen as to give rise to the conjecture that the species might not possess an aecidium. The species is usually listed under Puccinia nigrescens Pk. This specific name, however, belongs to the somewhat similar European species, as pointed out by Bubák, who unnecessarily bestowed the new name $P$. Saliriat-lanceolatae upon the American form. The rust occurs commonly upon the leaves, but is so much more conspicuous upon the stems, especially after the leaves have partly or wholly fallen, that most collections show the caulicolous form only.

5. Uromyces on Carex.-A species of Uromyces on Carex was found.at Fair Oaks, Ind., on March 22 in very great abundance, and in fine viable condition. The Carex grew in an open sandy woodland, but in a depression of the surface where water sometimes gathered during heavy rains. It grew in tufts over a half acre of ground, and belonged to two species, C. lanuginosa Michx., easily told from the abundance of last year's fruiting culms still present, and C. varia Muhl., which showed not a trace of last year's culms, and was determined from the fruiting of a plant transferred to the greenhouse, and verified by a subsequent visit to the locality on May 3. On this latter visit a careful search for aecidia was made in the vicinity of the rusted Carex, but "a few young leaves of a Solidago with spermogonia were the only result. These were growing with leaves intermixed and well surrounded by the rusted Carex. This was a very doubtful clue, as the common Solidago aecidium is known to belong to a Puccinia, yet experience has taught that the most improbable clues are not to be despised when the evidence is clirect. Before finding this clue, sowings of the rust on Carex zaria had been made on Viola Cucullaria, Isopyrum bitcrnatum. Trillium recurvatum, Rıbes Cynosbati and $R$. aureum with no infection. After the clue was obtained it was sown on five species of Aster with no infection, and on five species of Solidago with abundant infection. The following is the record of the latter. Sown May 6 on S. Canadensis L., showing abundant spermogonia on May 14, and aecidia on May 22. A sowing May 26 on S. serotina Ait. gave first spermogonia June 5, and aecidia June I6, the results being especially good. An equally successful culture was made on each of the two hosts at subsequent dates. Positive but less flourishing cultures were made on $S$. Alericaulis 
L. and $S$. caesia L., clearly in accordance with the vigor of the host plants, while a sowing on S. rigida L. wholly failed, the host showing a weak growth.

The above sowings were all made from material on Carex r'aria. The collection on C. lanuginosa, taken at the same time and place, appearing in every way to be the same species, and to be in equally viable condition, was sown under equally favorable circumtsances on Silphium perfoliatum, Ribes Cynosbati, five species of Aster, and on Solidago rigida, S. serotina and repeatedly on $S$. Canadensis, all with no infection.

Whether the failure to infect the Solidago was due to some undetected oversight in manipulation, or is an indication of specific or racial difference in the rust, is a matter for which the facts do not warrant an opinion.

It is not easy to determine if this rust has been previously described and named or not. Upon morphological grounds it is clearly distinct from Uromyces caricina E. \& E. and U. minutus Diet., but it may be the same as $U$. perigynius Halst. It also agrees well with collections from Wisconsin ${ }^{i 3}$ on Carex gracillima Schw., from Decorah. Iowa, ${ }^{14}$ on $C$. pubescens Muhl., and from Greencastle. Incl., on what was taken to be $C$. pubescens, but which a re-examination shows to be almost certainly $C$. virescens Muhl. If the rust on C. raria and C. lanuginosa had shown the same cultural hehavior. I would have been inclined to unite these several collections under one name. But realizing the need of allvancing cautiously among a group of species where only the first step has been taken, it seems wiser to give a separate name to the form about which we have definite knowledge, and leave the others to be dealt with later. The rust on $C$. varia with its alternate form is therefore, characterized under a new name, as follows :

URomyces Solidagini-Caricis nom. nov.

(). Spermogonia epiphyllous, in small groups on yellow spots, punctiform, honey yellow, subepidermal, in vertical section shown to be globose. about $115 \mu$ in diameter; isticlar filaments free, $60 \mu$ long.

I. Aecirlia hypophyllous, in groups, often circinating, peridia pale, low cylindrical, margin revolute, lacerate; aecidiospores globoid, or sightly elongated, $13-16$ by $14-18 \mu$; wall colorless, thin, $1 \%$ or sometimes a little more. minutely rugose.

II. Uredosori not seen; uredospores among the teleutospores oval or obovate, about 16 by 23 "': wall thin, echinulate.

III. Teleutosori hypophyllous, round, oblong or sometimes elongated. pulvimete. early naked, firm, chestnut-brown: teleutospores obovate. $15-18$ by $23-28 \%$, rounded or obtuse above, narrowed below: wall smooth. thin, $1.5-2 \%$, apex greatly thickened, $6-10 \%$; pedicel slender, tinted, as long as the spore, or longer.

${ }_{18}^{18}$ Trans. Wis. Acad. Sci. 9:180. 1892. Same 14:90. 1903.

${ }^{14}$ Bot. Gaz. I6:226. 1891.

${ }^{15}$ Same, 1. c. 
The collection on Carex raria Muhl., made at Fair Oaks, Ind., March 22, 1903, is taken as the type, together with the result of the culture on Solidago Canadensis L. obtained by a sowing made June 3, and matured July I, I9O3, at which date it was placed in the herbarium. I would tentatively refer here the collections referred to above on C. gracillima, $C$. pubescens, $C$. virescons (?) and C. lanuginosa, leaving their exact status to be deter. mined later.

The aecidium of this species does not appear to differ in any marked manner from that of Puccinia Caricis-Solidaginis Arth., although, perhaps, the spores are a trifle smaller. I have - not, however, had opportunity of collecting it in the field, as the heavy spring rains flooded the type locality and prevented all subsequent development of the rust, so that in subsequent visits at different times. during the season the most dilligent search failed to reveal any trace of it on either Solidago or Carex.

6. Anching pestelatem Curt.-In early April, 1902, an olservation was macle at Spirit Lake. Iowa, that proved very puzzling for a time. On an open prairie, that had been burned over during the late fall, a small area showed Comandra pallida A. DC. with aecidia, and in contact with it Andropogon scoparius Michx. bearing uredo, of the characteristic thin-walled sort linown to belong to the species with aecidium on Pentstemon. It was easy to find teleutospores on the grass leaves pressed into hollows, thus protected from the passing fire, and only in part germinated. These were collected and sown on Pentstemon hirsutus with no infection. A sowing was not made on Comandra, as no suitahle growing plants were available. A similar olservation was made again this year at Fair Oaks, Ind., and once more under circumstances that seemed to permit of no other inference but that the Comandra and Andropogon rusts were connected, highly improbable as it seemed. This time plants of Comandra umbellata (L.) Nutt. were secured. A sowing of telentospores from Andropogon furcatus Muhl. was marle on May 5. and spermogonia began to appear on May i6, but the host plant withered before time for aecidia to appear. A similar sowing was made on a more vigorous host, May 25, spermogonia appearing in great abundance May 30, and aecidia June 0. Another sowing of teleutospores from $A$. scoparius obtained in the same locality at Fair Oaks, was made on Comandra umbellata June I. the first spermogonia appearing June. 9. and aecidia June 19. Sowings of both sets of teleutospores were made twice on Pentstemon hirsutus, under the most favorable circumstances. with no infection. The conclusion is beyond all question, that a common rust on species of Andropogon, not readily distinguishable from Puccinia Andropogonis Schw.. has its aecidia on Comandra, being identical with Ae. pustulatum Curt. 
A rather careful study of the newly detected species appears to show that it is to be distinguished from $P$. Andropogonis Schw. by the very dissimilar aecidium, and by the pores of the uredospores, which number 5 to 8 and are distributed without order, while in P. Andropogonis they usually number 3, and are approximately equatorial. The name for the species should be Púccinia pustulata (Curt.) nom. nov.

7. Aecidium Ranunculi Schw. Ar. exceedingly fortunate observation was made in May, within a few miles of Lafayette, Ind. On a somewhat shaded hillside, an area not exceeding ten feet long by three feet wide, attracted attention by the yellowness of the new vegetation. Looking closer, it was found that the growing mass was made up almost wholly of Ranunculus abortir'us L. thickly covered with the Accidium Ramunculi Schw.. and an equal quantity of Eatonia Pennsylianica (DC.) A. Gray, intermixel, not yet in flower, but every leaf covered with a light yellow uredo. No other rusts occurred for some distance around, and even none on the same hosts elsewhere in the locality.

Healthy plants of Eictonia Pennsylianica were obtained from another locality, transferred to the greenhouse, and spores of Aecidium Ranunculi sown on the youngest leaves, May i3. From this sowing uredospores appeared on May 2I, and characteristic teleutospores began to show June 3 . Although the trial with telentospores cnuld not be made, yet the demonstration of the genetic relation of the two forms seems beyond question. A confirmatory observation upon the intimate association of the two forms in the field has been reported to me by Mr. E. W. D. Holway, from Decorah, Iowa.

This is one of the numerous grass rusts passing under the name of Puccinia rubigo-iera. It can not be called $P$. Ranunculi, as that name is preoccupied, and therefore, I propose the name

Puccinia Eatoniae nom. nov. (Aecidium Ranunculi Schw.)

O. Spermogonia hypophyllous, thickly scattered over large arens, preceding or among the aecidia, punctiform, honey-yellow, inconspicuous, stubepidermal.

I. Aecidia hypophyllous, evenly scattered over large areas; peridia broal and short. recurved, finely lacerate: aecidiospores subglobose or elliptical, $15-22$ by $18-25 \mu$; wall colorless. medium thick, $1.5-2 \%$, minutely verrucose: mycelium perennial in the host.

II. Uredosori chiefly epiphyllous, on yellow spots, small, oblong, pale yellow, ruptured epidermis noticeable; uredospores obovate-glohoid, $15-18$ by $20-23 \mu$; wall thin when mature, about $1 \mu$, pale yellow, finely and evenly echinulate, pores $6-8$, scattered.

III. Teleutosori chiefly hypophyllous and caulicolous, small, oblong to linear, covered by the epidermis; teleutospores oblong-clavate in linear-cuneate, $12-16$ by $35-45 \mu$, truncate or rounded above, narrowed below, slightly or not constricted at the septum; wall smooth, light brown. thin, $1-1.5 \mu$, apex a litte darker and thicker, $3-4 \mu$; pedicel very short, colored; paraphyses none, or few. 
8. Aecidium hydnoldeum B. \& C.-Coming upon some bushes of Dirca palustris L., the middle ot June, that were conspicuous with great numbers of yellow aecidial spots, search was made for grass and sedge rusts in the vicinity. At one side, hy a small ravine, was found a most luxurient growth of uredo upon Bromus ciliatus L., with last year's teleutospores on the lead radical leaves. The most distant bush of rusted Dirca was not over a hundred feet away.

As soon as suitable potted plants of Bromus ciliatus could be established in the greenhouse, aecidiospores from the Dirca were sown. The first sowing came to naught, as the host plant failed to grow well. A sowing on June 25 gave uredospores in abundance on July 4. Teleutospores were first observed on August IO, although they probably appeared somewhat earlier.

The success of this trial removes another rust from that limbo of grass forms passing under the name of Puccinia rubigoi'era. We may characterize the species as follows, under the name B. \& C.)

Puccinia hydnoidea (B. \& C.) nom. nov. (Aecidium hydnoideum

O. Spermogonia amphigenous in small groups on large yellow spots, inconspicuous, punçtiform?

I. Aecidia hypophllous, usually circinating about the spermogonia; peridia short, cylindrical, pale, margin slightly recurved, finely erose or torn: aecidiospores globoid or oblong-globoid, 11-15 by 14-19 $\mu$; wall yellowish, thin, $1 \mu$, minutely and inconspicuously verrucose.

II. Uredosori chiefly epiphyllous, oblong, early naked, pulverulent, fuscous; uredospores globoid or obovate-globoid, $18-21$ by $20-28 \mu$ : wall brownish, thin, $1 \mu$, abundantly echinulate, pores 4 or more, scattered.

III. Teleutosori chiefly hypophyllous and caulicolous. small and numerous, oblong, covered by the epidermis; teleutospores linear-oblong, $13-18$ by $30-50 \mu$, truncate or oblique above, obtuse or slightly narrowed below, not constricted at the septum; wall smooth, light brown, thin, 1-1.5 $\mu$, thickened at apex, 4-7 $\mu$; pedicel very short, colored; paraphyses none, or few.

This species, undoubtedly, does not embrace all the American rusts on Bromus. It is, doubtless, the common form east of the Rocky Mts. Probably the multicellular form, found in Wisconsin and Minnesota, Puccinia tomipara Trel., is distinct, although it has not yet been shown that such irregular multiplication of cells in the teleutospore is a permanent character.

\section{SUMMARY.}

The following is a complete list of successful cultures made during the season of 1903 . It is divided into the two series: species previonsly reported by the writer or other investigators, and species now reported for the first time. 


\section{A. Species previously reported.}

I. Puccinia Impatientis (Schw.) Arth. - Teleutospores from Elymus Virginicus L. sown on Impatiens aurea Muhl.

2. Puccinia amphigena Diet. - Teleutospores from Calamozilfa longifolia (Hook.) Hack. sown on Smilax hispida Muhl.

3. Puccinia Andropogonis Schw. - Teleutospores from Andropogon scoparius Michx. sown on Pentstemon hirsutus (L.) Willd.

4. Puccinia albiperidia Arth. - Teleutospores from Carex gracillima Schw. sown on Ribes Cynosbati L. and $R$. Uva-crispi L. (R. Grossularia L.)

5. Puccinia Helianthi Schw. - Teleutospores from Helianthus mollis Lam. sown on H. mollis Lam. and H. annuиs $\mathrm{L}$.

\section{B. Species reported now for the first time.}

I. Melampsora Medusae Thuem. - Teleutospores from Populus deltoides Marsh. sown on Larix decidua Mill.

2. Uromyces Phaseoli (P'ers.) Wint.-Teleutospores from Strophostyles heliola (L.) Britt. sown on same host.

3. Uromyces Lespedezae-procumbentis (Schw.) Curt. Teleutospores from Lespedeza capitata Michx. sown on same host.

4. Puccinia caulicola Tr. \& Gall. - Teleutospores from Salvia lanceolata Willd. sown on the same host.*

5. Uromyces Solidagini-Caricis Arth.-Teteutospores from Carex z'aria Muhl. sown on Solidago Canadensis L., S. serotina Ait., S. Alexicaulis L. and S. caesia L.

6. Puccinia pustulata (Curt.) Arth. - Teleutospores from Andropogon furcatus Muhl. and A. scoparius Michx. sown on Comandra umbellata (L) Nutt.

7. Puccinia Eatoniae Arth. - Aecidiospores from Ranunculus abortiz'us L. sown on Eatonia Pennsyluanica (DC.) A. Gray.

8. Puccinia hydnuidea (B. \& C.) Arth.-Aecidiospores from Dirca palustris L. sown on Bromus ciliatus L.

Judging from the few instances that have come to my notice, the interest and importance of making observations upon proximity of aecidial and teleutosporic forms are not yet fully appreciated by American collectors of Uredineae. This is the most valuable method by which a reasonable conjecture can be made regarding the alternate connection of any one of the many scores of isolated aecidial forms, most of which are probably heteroeci-

* Successful cultures reported by Kellerman, Jour. Mycol. 9:27, Dec. 1903. 
ous. Cultural work without such conjectures based on field observations are largely a waste of time, rarely leading to any positive information. The time to make observations is early spring. when the rusts first begin to show, mostly in April and May. Simple record of proximity is not especially important. The observations must show that the inference is well established, that the new growth of spores has come from germinating spores of another sort found near by. The ability to work out such an inference marks the logical and acute observer.

I desire to thank Messrs. Kellerman, Bates, Davis and Bartholomew for providing teleutosporic material, and also $\mathrm{Mr}$. Holway for numerous favors. I have already mentioned the kindness of Messrs. R. Douglas' Sons in providing host plants; strong plants of Callirrhoc involucrata were sent by $\mathrm{Mr}$. Bartholomew. My particular thanks, moreover, are due to the Botanical Society of America for providing funds by which the work could be prosecuted, not only in the laboratory but in the field. The observations at Fair Oaks. Ind., by far the most important of those made in a single locality, were rendered possible by the society's generosity.

Purdue University, Lafayette, Ind. 



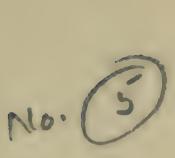

$4^{3}$

CULTURES OF UREDINEAE IN 1904.

J. C. ARTHUR. 


\section{4}

(Reprinted from the Journal of Mycology, 11 : 50-67, March 1905)

\section{CULTURES OF UREDINEAE IN $1904 .^{1}$}

J. C. ARTHUR.

The present article forms the fifth of a series of reports ${ }^{2}$ by the author upon the cultures of plant rusts. They cover the years from i 899 to the present year inclusive. In these studies the grass and sedge rusts hold a prominent place, but some other heteroecious and a few autoecious rusts have been included.

During the period when the cultures are in progress, the constant attention of one person is required to assort the material which is in germinating condition from that not yet ready to germinate, to sow the spores, to maintain a careful watch for the first appearance of the spermogonia and aecidia, and to keep the records with unimpeachable accuracy. At the beginning of the present season the Indiana Experiment Station established a cooperative agreement with the Bureau of Plant Industry of the U. S. Department of Agriculture to mutually assist in carrying on the annual culture work. Through the government assistance Mr. F. D. Kern, a senior student from the University of Iowa, recommended by Professor T. H. MacBride, was secured to take charge of the cultures. Mr. Kern proved an exceptionally able man for the position, having unusually keen and accurate powers of observation, a retentive memory, and scholarly enthusiasm. Mr. Kern's work extended through May, and a part of April and June.

${ }^{1}$ Read before the Botanical Society of America, Philadelphia, December 30,1904 .

${ }^{2}$ See Bot. Gaz. $29: 268-276$; Jour. Mycol. 8:51-56; Bot. Gaz. 35 :10-23, and Jour. Mycol. 10:8-21. 
I am under many obligations to a number of botanists, who have most kindly sent me teleutosporic material, and in some cases particular host plants on which sowings could be made. My especial thanks are extended to those who have made field observations, and provided me with clutes to solve the relationship of isolated forms, the information received from Rev. J. M. Bates, and Mr. E. W. D. Holway, being particularly helpful. Further acknowledgments are made under the several species. I should further mention the kindness of Messrs. R. Douglas' Sons, of Waukegan, I11., who sent twenty-five thrifty young larch without asking payment, as they did a year ago.

During the present season 90 collections of material were employed, and 261 drop cultures and ro Petri dish cultures were made from them to test the germinating condition of the spores. Out of these 38 collections refused to germinate, and were consequently useless. There were in all 264 sowings of spores made, representing 40 species of rust, and for this purpose were required II 9 species of hosts temporarily grown in pots in the greenhouse.

A few cultures were made with material for which no clues were obtainable to indicate the possible relationship, and in every case with negative results. The record is given here, as in previous years, to serve for future reference.

I. Puccrinia on the leaves of Elymus Canadensis L., sent by Rev. Bates from Red Cloud, Neb., was sown on Baptisia tinctoria, Polygala Senega, Uvularia perfoliata, Mimulus ringcns, Symphoricarpos pauciflorus, and $S$. racemosus, with no infection. Two other hosts were tried in 1903 , with equally negative results. ${ }^{3}$

2. Puccinia on Muhlenbergia Mexicana, sent by Mr. E. Bartholomew from Stockton. Kans., was sown on Hibiscus miliiaris, with no infection. Similar material sent by Rev. J. M. Bates from Red Cloud, Neb., on M. racemosa, was sown on Asclepias incarnata, and twice on Hibiscus militaris, with no infection. What is probably the same fungus on the latter host coming from Callaway, Neb., was sown in 1902 on ten other species of hosts with equally negative results. * It is evident that while some of the rust found upon Muhlenbergia undoubtedly is associated with the aecidium on Hibiscus, as Professor Kellerman clearly proved last year, ${ }^{5}$ there are other forms háving entirely different aecidia, not yet ascertained.

3. Puccinia on Carex Pennsylvanica, sent by Rev. Bates from Red Cloud, Neb., was sown on Ambrosia tritida, Polemonium reptans, Erigeron annuus, Lepidium apetalum, and Solidago

Jour. Mycol. $10: 10.1904$.

- Bot. Gaz. $35: 11.1903$.

Jour. Mycol. 9:109, 232. 1903. 
Canadensis, with no infection. Similar material on the same species of host, gathered at Lafayette, Ind., was sown on Oxalis violacea, Actaea alba, Macrocalyx Nyctelea, Apios Apios, and Solidago ulmifolia, with no infection. What is probably the same species of rust, on the same host, was sown in 1903 on eleven other species of hosts with negative results. ${ }^{6}$

4. Puccinia on Carex gravida, sent by Rev. Bates from Red Cloud, Neb., was sown on Steironema ciliatum, with no infection. Similar material from the same source was sown in 1903 on twelve other species of hosts with negative results. ${ }^{7}$

5. Puccinia ludibunda E. \& E., sent by Mr. E. Bartholomew from Stockton, Kans., was sown upon Steironema ciliatum, Macrocalyx Nyctelea, and Xanthium Canadense, with no infection.

6. Peridermium on Pinus rigida was sent by Professor W. A. Kellerman from Sugar Grove, Ohio, in fine quantity, with the suggestion that it would probably grow upon Campanula. It was sown June Ist on what were supposed to be four plants of C. Americana, but which proved to be Lobelia syphilitica, when the plants came into bloom. The plants were unusually thrifty, and conditions for success were good, but there was no infection. Part of the same collection of spores grew on C. Americana, when sown by Prof. Kellerman, ${ }^{8}$ showing that they belonged to Coleosporium Campanulae (Pers.) Lev.

Sixteen species of rusts were successfully grown, that had been studied with success before, and reported upon by the writer and in part by other investigators. Mention of them here serves to confirm previous work, and to give some additional knowledge regarding hosts.

i. Melampsora Miedusae Thuem.-Teleutosporic material of this species on Populus deltoides was obtained near Lafayette, Ind., and sown May Io on Larix decidua and Euonymus oboratus. The latter gave no result, but the former showed spermogonia on May 25, yet owing to weakness of the hosts no aecidia formed. The same collection was used to sow on Larir laricina (Du R.) Koch (L. Americana Michx.) May 23, which showed spermogonia June 4 , but the host was too weak to permit aecidia to form.

Teleutosporic material on $P$. deltoides at Spirit Lake, Iowa, by the writer was sown May ro, on Larix decidua and L. laricina, with only feeble results on the former owing to the weakness of the hosts. Another sowing was made May 23 on L. decidua, which gave abundance of spermogonia on May 30 , and an equal abundance of aecidia on June 4.

$\begin{array}{lll}\text { CJour. Mycol. } 10: 10 . & 1904 . \\ \text { 7 Jour. Mycol. } 10: 10 . & 1904 . \\ \text { ' Jour. Mycol. } 11: 32 . & 1905 .\end{array}$ 
Teleutosporic material on Populus tremuloides Michx. was sent from Racine, Wis., by Dr. J. J. Davis, and was sown on Larix decidua, May 25. Abundance of well developed spermogonia appeared on June 5, followed by strongly developed aecidia on June 10. This culture is specially significant in showing that the poplar rust of North America is probably all of one species, as assumed in last year's report of cultures. ${ }^{\circ}$

2. Phragmidium speciosum Fr. has twice before been the subject of cultures, being grown in $1899^{10}$ on a tea rose from the garden, and in $1902^{11}$ on Rosa humilis. The teleutosporic material used this season was obtained by the writer at Spirit Lake, Iowa, on Rosa Arkansana. It was sown on R. Arkansana Port., $R$. Carolina L., $R$. humilis Marsh., and $R$. nitida Willd., with abundant success in each case. It was sown twice on $R$. lucida Ehrh. without success, although the host was in fine growing condition. The dates were as follows:

May 7, Teleutospores sown on R. Arkansana; May 14, spermogonia; May 20 , aecidia.

May 7, Teleutospores sown on R. Carolina; May 14, spermogonia; May 18, aecidia.

May 17, Teleutospores sown on $R$. humilis; May 23, spermogonia; May 30 , aecidia.

May 17, Teleutospores sown on $R$. lucida; no infection.

June 1, Teleutospores sown on $R$. lucida; no infection.

June 1 , Teleutospores sown on R. nitida; June 8, spermngonia; June 15 , aecidia.

Whether the failure to infect $R$. lucida was due to the greater mechanical resistence of the firm leaves, or to a physiological difference in the host can not be stated, but I am inclined to favor the former explanation.

3. Puccinia Helianthi Schw.- Three collections of sunflower-rust were used for cultures this season. A collection was cbtained from Spirit Lake, Iowa, on Helianthus laetiflorus, one from Fair Oaks, in northern Indiana, on $H$. mollis, and one from Lafayette, Ind., on H. grosse-scrratus, all by the writer. Another collection was used, but the host could not be determined with certainty, and the results are discarded. Three collections seemed to be in perfect condition, but could not be made to germinate. Forty sowings were made from the three collections used, and as a large space would be required to report the full data, the results will be given in tabular form. In this table decided and complete results are shown by an exclamation point, infection which was meager, grew slowly and gave no aecidia or very few, is shown by a semicolon, a sowing which gave no infection is indicated by a single period, and where no sowings were made a dash is used. Fifteen

- Jour. Mycol. $10: 13.1904$.

${ }^{10}$ Bot. Gaz. $29: 271.1900$.

"Bot. Gaz. $35: 17.1903$. 
species of Helianthus were employed, on which to sow the teleutospores.

\section{CULTURES OF HELIANTHUS RUST.}

Hosts for cultures

1. H. annuus ...........

2. H. decapetalus .......

3. $H$. divaricatus .........

4. H. grosse-serratus ...

5. H. hirsutus .........

6. H. Kellermani .......

7. H. laetiflorus $\ldots . . .$.

8. H. Maximiliani .....

9. H. mollis ...........

10. H. occidentalis .......

11. H. orgyalis ..........

12. H. scaberrimus ......

13. H. strumosus ........

14. $H$. tomentosus .......

15. H. tuberosus .........

Source of teleutosporic material $H$. mollis $H$. grosse-serratus $H$. laetiflorus !

$$
\text { - }
$$$$
\text { . }
$$

! Abundant infection.

; Infection, but slow growth and few or no aecidia formed.

. No infection.

- Not sown.

The results of this year accord closely with those of 1902 and 1903. In 1902 some success was attained in sowing spores from $H$. grosse-serratus on $H$. Marimiliani, but no success this year. In 1903 sowing spores from $H$. mollis on $H$. strumosus gave no infection, this year a few spermogonia were formed, but no further development took place. In all other respects the work of the three years is in perfect accord. Altogether sixtyfour sowings have been made.

Looking over the accompanying table it will be seen that each set of spores grew upon the species of host from which derived, but not upon the other two species, except that spores from $H$. laetiflorus sown on $H$. mollis gave a tardy showing of spermogonia, without further development. Also each set of spores grew luxuriantly upon $H$. annuus, and each made a feeble growth upon $H$. tomentosus, but on all other species they either failed to infect or made a feeble growth, with the single exception that spores from $H$. lactiflorus grew well on $H$. scabcrimus.

From all results so far available, it seems that the following conclusion may safely be drawn. Puccinia Helianthi Schw. is a single species, having many races, for which $H$. annuus acts as a bridging host.

4. Puccinia subnitens Diet.-Teleutosporic material of this species on Distichlis spicata (L.) Greene were sent from Nebraska by Rev. J. M. Bates, to whom I am also indebted for suggestions which led to one of the most interesting series of cultures yet made. In a communication dated April 30, 1904, 
Rev. Bates says: "Last spring I found Aicidium on Cleome scrrulata in two nearby localities, and on Chenopodium album, closely associated with the rust on Distichlis spicata, and no other. Now I have it again under same conditions. I wrote $\mathrm{Mr}$. Holway ahout it and shocked him; he does not think it possible. But 1 am well convinced that it is the same as on Chenopodium" [proved by cultures in 1902 from Distichlis-rust sent by Rev. Bates]. Further reasons were given for believing that the Cleome and Chenopodium aecidia came from teleutospores on Distichlis, among them being that "last year I watched for the uredo from it on the Distichlis, and got it May 2I, after collecting the first Cleome aecidia May 5." All these observations seemed very convincing, yet the deductions seemed very improbable. He followed up the statements by sending seedling plants of Clconne scrrulata and Chenopodinm album on which the large, brilliant orancre-colored aecidia nccurred in remarkable profusion, and so much alike that in appearance and structure they had to be pronounced identical. As the season progressed Rev. Bates also sent freshly collected specimens of aecidia on Roripa sinuata (Nutt.) Hitch.. Sophia incisa (Engelm.) Greene, and Salsola Tragus L., which he considered belonged to the same inclusive species. The results of my cultures confirm the above clever observations, and add still other hosts for the aecidium. The data are as follows:

May 17. Sown on Chcnopodium album; May 25, spermogonia; June 5, aecidia.

May 17, Sown on Cleome spinosa; May 25, spermogonia; May 30, aecidia. May 17, Sown on Lepidium apetalum; May 25, spermogonia; June 7, aecidia.

May 30, Sown on Lepidium Virginicum; June 7. spermogonia; June 16, aecidia.

May 30, Sown on Sophia incisa; June 7, spermogonia: plant injured.

May 30, Sown on Erysimum asperum; June 5, spermogonia; June 14, aecidia.

May 30, Sown on Cleome spinosa; June 5, spermogonia; June 14, aecidia.

We have here a demonstration of the remarkable fact, not known for any other species of rust so far as I recall, that Puccinia subnitens with teleutospores on Distichlis spicata has aecidia growing with equal vigor upon species belonging to three families of plants. The teleutospores for the above sowings were all taken from the same collection, and from only a few leaves of the grass, which precludes the possibility of a differentiation in the teleutoform, or any division into races. The aecidium is unusually well marked. Going over my herbarium and taking out the forms which are identical with this species, beyond a doubt, and adding to those already mentioned, we have the following hosts and distribution for the aecidium of this species. 
Puccinia subnitens Diet.

On Chenopodiaceae:

Chenopodium album L. Montana, New Mexico, Nebraska.

Chenopodium leptophyllum (Moq.) Nutt. Nebraska.

Chenopodium glaucum L. Montana.

On Capparidaceae:

Salsola Tragus L. Nebraska.

Cleome serrulata Pursh. Nebraska, Montana.

On Cruciferae:

Cleomella parviflora A. Gr. Nevada.

Lepidium apetalum Willd. Nebraska, Montana.

Roripa sinuata (Nutt.) Hitch. Nebraska.

Sophia incisa (Engelm.) Greene. Nebraska.

Stanleya pinnata (Pursh.) Britt. Colorado.

5. Puccinia Panici Diet.- The connection of this rust with EEcidium Pammelii Trel. on Euphorbia corollata L. was reported by William Stuart ${ }^{12}$ based on somewhat meager but seemingly convincing cultures made in Iyol. Teleutosporic material for the present trial was oltained at Fair Oals, Ind.. on Panicum virgatum. It was sown on Euphorlia corollata May I6, and again May 24, and both sowings showed the most abundant results, giving the first spermogonia respectively on May 24 and June I, and aecidia May so and June 9. There can be no doubt that these two forms are nembers of one species. While at Lafayette the rust is very rare, at Fair oals it is exceedingly abundant one on both the Panicum and the Euphorbia. It is one of the few glumaceous rusts observed by the writer, having so nearly an equal display of both the aecidial and teleutosporic forms. The aecidial form having first been published, requires the name to be written Prccinia Pammeli (Trel.) nom. nov.

6. Puccinia verbenicola (E. \& K.) Arth.-Previous cultures $^{13}$ with this species were verified by sowing teleutospores, from Sporobolus longifolius sent by Rev. J. M. Bates from Red Cloud, Neb., on Verbena urticaefolia, May 16, resulting in spermogonia May 23, and aecidia May 30. Also another successful culture was made with similar material sent by Mr. E. Bartholomew from Stockton, Kans., sown on $Y$. urticacfolia June 3, showing spermogonia June II, and aecidia June I8.

7. Puccinia Windsoriae Schw. - Teleutospores from Tricuspis seslerioides Torr. Lafayette, Ind., were sown May 19, on Ptelca trifoliata and Xanthoxylum Anericanum, both members of the family Rutaceac, and both known to be hosts to an aecidium. Although the conditions were exceptionally favorable, no infection resulted on Xanthoxylum, while Ptelea

${ }^{12}$ Proc. Ind. Acad. Sci. for $1901: 284.1902$.

${ }^{13}$ Bot. Gaz. $29: 274 . \quad 1900$, and $35: 16.1903$. 
gave spermogonia May 25, and aecidia May 3I, in accordance with results heretofore obtained. ${ }^{14}$

8. Puccinia Fraxinata (Schw.) Arth.-Cultures of this species were successfully carried out in $1899,{ }^{15}$ showing that the aecidium occurs upon Fraxinus. As similar aecidia have been collected upon Ligustrum vulgare L., in New York, and Adelia segregata (Jacq.) Small (Forestiera porulosa Poir.) in Florida, ${ }^{16}$ members of the family Oleaceae, to which Fraximus belongs, a number of trials were made to see if the number of hosts could be extended. Telcutosporic material was obtained at Spirit Lake, Iowa, on Spartina cynosuroides. Sowings were made on Ligustrum vulgare (2), Ligustrum ovalifolium (2), Syringa vulgaris (2), Chionanthus Virginica (2), Adelia acuminata, Adelia ligustrina, and Fravinus lanccolata, all members of the family Olcaccae, yet no infection took place except on the last host. Although the conditions for success were seemingly excellent, still I am not fully convinced that some of these failures were not due to accident. I am under obligation to Dr. George V. Nash, of the N. Y. Bot. Garden, for a plant of Adelia acuminata, sent from the Garlen for this culture work.

9. Puccinia Impatientis (Schw.) Arth.-Teleutosporic material on Elymus Virginicus was sent from Racine, Wis., by Dr. J. J. Davis, and sown May 7, on Clematis Virginiana and Impaticns aurca. The first save no infection, the second showed spermogonia May I4, and aecidia May $23 .{ }^{17}$

io. Puccinia poculiformis (Jacq.) Wettst. - Teleurosporic material was found at Spirit Lake, Iowa, on Elymus Canadensis L., and without a careful examination was sown on $\mathrm{Clc}$ matis Virginiana (2), C. Scottii, Cimicifuga Americana, C. racemosa. Actaca alba, and Impatiens aurea, with no infection. A microscopic study revealed the nature of the rust, and it was sown upon Berberis vulgaris May 18 , with abundant infection, spermogonia appearing May 25, and aecidia duly following, but not recorded until June 9. Telettosporic material was also found at Spirit Lake, Iowa, on Agropyron tenerum, and was sown or: Berberis vulgaris May 10 , giving an abundant infection, first showing spermogonia May 17 . followed in due time by aecidia. Teleutosporic material on Agropyron repens was sent from Burlington, Vt., by Mr. William Stuart, and sown on Berberss rulgaris May Ir. Spermogonia appeared May 18, but the leaves were injured before aecidia developed.

${ }^{14}$ Bot. Gaz. $29: 273 . \quad 1900$, and 35:16. 1903.

${ }^{15}$ Bot. Gaz. $29: 275.1900$.

${ }^{16}$ Specimen in herbarium of N. Y: Bot. Garden, and cited by Sydow, Monog. Ured. 1:808, under the erroneous name $F$. "paludosa".

${ }^{17}$ For previous cultures see Bot. Gaz. 35:18. 1903, and Jour. Mycol. $10: 11 . \quad 1904$. 
II. Puccinia Rhamni (Pers.) Wettst. - A number of bushes grow in the garden near the laboratory of Rhammus lanceolata, $R$. Caroliniana, and $R$. Cathartica, on which aecidia appeared this season, not very plentifully, but in about equal abundance. Seedlings of Avena satica were infected from all three sources. Acidiospores were sown from $R$. lanceolata May I5, from $R$. Caroliniana May I9, and from $R$. Cathartica May 20. In each case uredospores appeared in abundance in about a week, the exact date not being recorded.

I2. Puccinia Angustata Peck.- Teleutospores gathered on Scirpus atrovirens, Lafayette, Ind., were sown May I2, on Lycopus Americanus, giving spermogonia May 20, and aecidia May 27, further confirming previous cultures. ${ }^{18}$

I3. Puccinia Pecki (DeT.) Kellerm.- Successful sowings ${ }^{19}$ of teleutospores from undetermined species of Carex were made on Onagra biennis, from material sent by Rev. J. M. Bates of Red Cloud, Neb., and by Dr. J. J. Davis of Racine, Wis. A sowing was also made. May 20 , on $O$. bicnnis, from material on C. lanuginosa sent by Rev. Bates from Red Cloud, Neb., which gave spermogonia May 29, and aecidia June 5. The same material was sown on Urtica gracilis twice without success. This gives a new host for the fungus.

Teleutosporic material on Carcx trichocarpa from the type locality of Puccinia Bolleyana, was sown May 6, on Onagra biennis and Sambucus Canadensis, producing infection on both hosts, and thus repeating the experience of $1902 .^{20}$ The Carex bore teleutospores of both P. Peclii and P. Sambuci (Schw.) Arth. intermixed, as was easily verified by microscopic examination.

I4. Puccinia Caricis-Erigerontis Arth.- Teleutospores gathered at Lafayette. Ind., on Carex festucacea were sown on Erigeron anmus, May 12, giving heavy infection of spermogonia May 20. and of aecidia May 27. Similar material on the same host, sent by Rev. Bates from Red Cloud, Neb., was sown May 25. on E. annuus, and gave spermogonia June 2, and aecidia June 9. These results confirm previous work. ${ }^{21}$

15. Puccrnia albiperidia Arth. While the conviction is gaining ground that the aecidium of this species is the common aecidium on gooseberries, yet the excellent results of this year do not give any particular support to the view. All the aecidia grown in cultures were small and pale, and apparently

${ }^{18}$ Bot. Gaz. $29: 273 . \quad 1900$, and Jour. Mycol. 8:53. 1902.

${ }^{10}$ For previous cultures see Jour. Mycol. 8:55. 1902, and Bot. Gaz. $35: 13.1903$.

${ }^{20}$ Bot. Gaz. 35:14. 1903.

" Jour. Mycol. 8:53. 1902, and Bot. Gaz. 35:15. 1903. 
dissimilar to the bright orange-yellow aecidia on Ribes in the fields.

Teleutosporic material was sent by Dr. J. J. Davis from Racine, Wis., on Carex gracillima, which was sown on Ribes floridum (3), R. rubrum, and $R$. aureum (2), with no infection, except that in one case a few spermogonia appeared on $R$. aurcum after eleven days, but reached no further development. It was also sown with abundant success on $R$. Uva-crispa (2), R. Cynosbati and $R$. rotundifolium (2), thus confirming previous work. ${ }^{22}$

Excellent teleutosporic material was found on Carex crinita Lam., Lafayette, Ind., and sown May 7, on Ribes rubrum, with no infection, on $R$. Ura-crispa. with weak infection, the plant being in poor condition, and on $R$. rotundifolium with strong infection, showing spermogonia May 17 , and aecidia May 25. Another equally strong infection was secured with a sowing on the last host June 3 . This culture adds another teleutosporic host.

i6. Puccinia Polygoni-Ampinbil Pers. In previous years $^{23}$ this rust was sown upon three species of Polygonum and Cicuta maculata with no infection. After learning of Dr. Tranzschel's successful cultures on two European species of wild geranium ${ }^{24}$ considerable effort was made to secure teleutosporic material with which to repeat the work. No rust could be found about Lafayette where it usually occurred. At Spirit Lake, Iowa, a diligent search where it had previously been common, only gave a few slightly rusted leaves. No better success was met with at Fair Oaks, Ind. An appeal to my excellent coadjutors, Prof. W. A. Kellerman, Columbus, Ohio, Rev. J. M. Bates, Red Cloud, Neb., and Dr. J. J. Davis, Racine, Wis.. brought out the same experience, and only added a few slightly rusted leaves from Wisconsin. The three meager collections were, however, useless, as none of the teleutospores would germinate. I then waited for aecidia to appear on geranium and found them as rare as the teleutospores had been. Finally I obtained a few belated aecidia on Geranium maculatum L. (AE. sanguinolentum Lindl.) and sowed them on Polygonum cmersum (Michx.) Britt., June II, and on June 19, uredospores appeared, and eventually on Aug. I7, teleutospores began to form, the plants being kept in the greenhouse during the culture. The American and European forms are therefore identical.

Jour. Mycol. 8:53. 1902, and 10:11. 1904.

${ }^{23}$ Bot. Gaz. 35:12. 1903, and Jour. Mycol. 10:9. 1904.

${ }^{*}$ Centr. f. Bakt. $11^{2}: 106.1903$. 
In addition to the foregoing results five species of rusts were grown, establishing aecidial and teleutosporic connections, not heretofore recorded. The species are heteroecious with one exception.

I. Melampsora Bigelowil Thüm. - Three collections of teleutospores on Salix were secured, but only one, which was obtained at Racine, Wis., on Salix amy'gdaloides Anders., and forwarded by Dr. J. J. Davis, could be made to germinate. This was sown, May Io, on Larix decidua Mill., and twenty days later both spermogonia and aecidia were observed in abundance, although they had probably first made their appearance some days earlier. On the same date it was sown on Euonymus obovatus without result. A further sowing on Larix decidua was made on May 25, and on June 4 spermogonia began to appear in great abundance, followed on June 10 by an equal abundance of aecidia. The aecidia are of the typical cacomaform, and are very similar to those of Mclampsora Mcdusae, the chief difference being in the spores, which are somewhat more distinctly and coarsely verrucose than in the poplar form.

The only American collections of aecidia on Larix, that have cone to my attention, were made by E. W. D. Holway at Mt. Temple, Aug. 22, 1902, and Laggan, Aug. 23, 1902, both places in Alberta. Canacia, and both collections on Larix Lyallii Parl. These collections agree perfectly with the aecidia raised in cultures. A comparison of the numerous collections of willow rust in my own herbarium, numbering 80 packets, and representing all sections of the United States and Canarla from the Atlantic to the Pacific, shows that both the uredosporic and teleutosporic stages arrce closely with one another, and with those on the material used in the culture.

A comparison with European collections shows the American form to be very different from any European species. The nearest approach to the American form is Melampsora Lariciepitca Kleb.. the most common willow rust of Europe. The two cliffer, however, in a very marked way. The American form has all three sorts of spores considerably larger, the spores of the aecidia and uredo have walls twice as thick, the pores are far more evident, and the papillae on the surface are much closer together.

The name which I have adopted for this common willow rust was given by Baron von Thuemen to a collection made in California on Salix Bigelowii, which he stated had been received from the herbarium of Dr. W. G. Farlow. Von Thuemen's herbarium was burned some years ago, and the type is consequently destroyed. In reply to an inquiry regarding the matter, Dr. Farlow states that he does not recall sending such a specimen to von Thuemen, and is unable to find a correspond- 
ing specimen in his herbarium, unless one from Santa Cruz, Calif., collected by Dr. C. L. Anderson, November, 1875, could be the one intended. This specimen, however, is said to be upon Salix brachystachys.

Although the type collection can not be accurately identified or duplicated, there seems to be no reason to question the reference of the fungus described to the common willow rust growing throughout California and the other parts of North America. Dr. Farlow kindly sent me a part of his specimen on $S$. brachystachy's, and also a specimen on S. Bigclozvii, collected in Washington by C. V. Piper in 1899 , and they agree in all essential particulars with the eastern collections on willow.

I have also had the privilege, through the kindiness of $\mathrm{Mr}$. Chas. H. Peck, of examining the type specimen of Lecythea mucrosora Pk. (Bot. Gaz. 5:35. I880), collected in Colorado by Brandegee, and thought to be on Epiliobium, and find that it is the uredostage of this same species of willow rust. An examination of type material of Melamspora paradoxa D. \& H. shows no important deviation from the common form. The peculiar free teleutospores figured by Dr. Dietel (Hedw. Beibl. $40: 33$. I I901) appear to be occasional reversional forms, due to disturbed nutrition or some such cause. Similar isolated tclentospcres have heen (lescribed by Klehahn in European material (Ztschr. f. Pf.-Kr. 9:98). The name, Melamspora maculosa D. \& H., is nomen nudum." It was applied to forms showing especially bright yellow discoloration of the leaf about the uredosori, but without other marked characters, as examination of type material shows.

The species may be characterized as follows:

Melampsora Bigelowil Thuem.

0. Spermogonia amphigenous, scattered, or somewhat gregarious, minute, functiform, pale yellow, inconspicuous, subcuticular, conical, 60-80 $\mu$ in diameter, $40-45 \mu$ high.

I. Aecidia chiefly hypophyllous, scattered or somewhat gregarious, small. .1-.2 mm. across, oblong, pale yellow fading to white, inconspicuous, formed between the epidermis and mesophyll, soon naked, pulverulent; aecidiospores glohoid, $15-22$ by $18-27 \mu$; wall colorless, $2-3 \mu$ thick, fincly and evenly verrucose, with distinct papillae, pores scattered, noticeable.

On Larix Lyallii Parl., Alberta, Can., and probably on other species of Larix in varions parts of the United States and Canada. Cultivated on $L$. decidua Mill. and L. laricina (DuR.) Koch.

II. Uredosori chiefly hypophyllous, usually on conspicuous yellow spots, scattered or gregarious, round, .3-.5 mm. across, orange-yellow fading to pale yellow, soon naked, somewhat pulverulent: uredospores globoid, $15-19$ by $17-24 \mu$. wall colorless, $2.5-3.5 \mu$ thick, sparsely and evenly verrucose, pores scattered, noticeable: paraphyses intermixed with the spores, capitate, smooth, 50-70 $\mu$ long, heads $22-25 \mu$ broad, wall 3-5 $\mu$ thicl, peripheral paraphyses thinner walled and more clavate.

III. Teleutosori amphigenous, or sometimes partly or wholly epiphyllous or hypophyllows, ccattered, roundish or irregular, about $.5 \mathrm{~mm}$. across, often confluent, orange-yellow becoming yellowish or purplish 
brown, subepidermal ; teleutospores prismatic or oblong, 11-14 by $29-42 \mu$, rounded at both ends; wall cinnamon-brown, smooth, uniformly $1 \mu$ thick.

On Salix amygdaloides Anders., and many other species of Salix, throughout the United States and Canada.

Beside this common willow rust, another is known to occur on Salix herbacea L. in Greenland and on Mt. Washington, N. H., Melampsora artica Rostr. One other, Mclampsora repentis Plowr., on Salix repens has been reported from North America, but has not been seen by the writer.

2. Puccinia tomipara Trel. - I am indebted to Mr. E. W. D. Holway for the suggestion, which led to the certain demonstration of the aecicial connection for this species. Mr. Holway's observations were made in the ficld, and showed such close association of the recently germinated teleutospores on over-wintered leaves of Bromus cilinlus and the appearing aecidia on Clcmatis Virginiana, that the conclusion seemed foregone. His direct observations extended over two seasons. Telentosporic material gathered by Mr. Holway at Decorah, Iowa, was sown on Impatiens aurea, Dirca palustris, Clematis Virginiana, C. Fremontii, C. Scoitii, C. Viorna, and with no infection except on Clematis Virginiana. Teleutosporic material of Bromus ciliatus was kindly sent by Dr. J. J. Davis from Kenosha Co., Wis., and sown on Clematis Virginiana with most abundant infection. Material was also used, obtained near Lafayette, Ind., on Bromus ciliatus, and sown on Dirca palustris and Clenatis Virginiana with no infection of the former and the most plentiful infection of the latter. The record of dates is as follows:

May 12, Teleutospores (Iowa) sown on Impaticns aurea; no infection. May 12, Teleutespores (Iowa) sown on Dirca palustris; no infection.

May 12, Teleutospores (Iowa) sown on Clematis Scottii; no infection. May 12, Teleutosfores (Iowa) sown on Clematis Fremontii; no infection. May 12, Teleutospores (Inwa) sown on Clematis Virginiana; May 19, spermogonia; May 28, aecidia.

May 18. Telcutospores (Ind.) sown on Dirca palustris; no infection.

May 25. Teleutospores (Iowa) sown on Clematis Scottii; no infection.

May 25, Teleutospores (Iowa) sown on Clematis Fremontii; no infection.

May 25, Teleutospores (Iowa) sown on Clematis Viorna; no infectiop.

May 25, Teleutospores (Iowa) sown on Clematis Virginiana; May 31, spermogonia; June 9, aecidia.

May 30, Teleutospores (Ind.) sown on Dirca palustris; no infection.

May 30, Teleutospores (Ind.) sown on Clematis Virginiana; June 7, spermogonia; June 15 , aecidia.

June 3, Teleutospores (Wis.) sown on Clematis Virginiana; June 9 , spermogonia; June 16 , aecidia.

This record shows that the report made last year, connecting the teleutosporic stage on Bromus ciliatus with the aecidium on Dirca palustris ${ }^{25}$ was a mistake. The teleutosporic material from Lafayette, which grew so abundantly on Clematis Virginiana this year, came from the same plants that

${ }^{25}$ Jour. Mycol. 10:19. 1904. 
were mentioned as bearing teletitospores a year ago, and standing near aecidium-laden bushes of Dirca palustris. Last year's supposed results, which were based on a single sowing of aecidiospores, can be explained by supposing that the Bromus plants were already infected when brought into the laboratory. The above plentiful data show no escape from the conclusion that the common Bromus rust belongs to the aecidium on Clemalis Virginiana, and not to the aecidium on Dirca palustris. The name Puccinia hydnoidea (B. \& C.) Arth., therefore, does not belong to the Bromus rust, but to some teleutosporic form not yet identified. The descriptions of uredospores and teleutospores given at the place cited belong to Puccinia tomipara Trel.

There are at least three species of aecidia found upon Clematis in the United States. Accidium occidentale Arth. occurs on $C$. Douglasii in the northwestern region; its teleutosporic connection is not known. Aecidium Clematidis DC., found on C. Iigusticifolia, C. Scottii, C. Fremontii, C. Drummondii, C. lasiumtha and C. Viorna, ranging from Iowa to Montana and southwestward to the Pacific coast, is the first stage of Puccinnia Agropyri E. \& E. The third species is Aecidium Clematitis Schw., the one under consideration, found on C. Virginiana, ranging throughout the United States and Canada east of the Rocky mountains, and belongs to Puccinia tomipara Trel. It has larger spermogonia, and somewhat smaller aecidia and aecidiospores than that of $P$. Agropyri. It may be characterized as follows:

Aecidium Clematitis Schw.

0 . Spermogonia epiphyllous, in small groups, honey-yellow, punctiform, subepidermal, globose, $90-140 \mu$ in diameter; ostiolar filaments $40-60 \mu$ long.

I. Aecidia hypophyllous, in orbicular groups, crowded; peridia low, margin somewhat revolute. erose; aecicliospores globoid, 16-22 by 18-26 $\mu$, wall rather thin, $2 \mu$, colorless, minutely verrucose.

The teleutospores used in the cultures were all of the normal two-celled form. The original collection on which the name was based does not appear to differ in any appreciable way from the usual two-celled form except in the many-celled teleutospores, which appear to be variations not uncommon in many grass species. The hosts of all three collections used in the cultures were of the form often made a distinct species under the name Bromus purgans L., which differs but slightly, chiefly in pubescence, from the typical $B$. ciliatus.

3. Puccinia Stipae Arth. - On May 9, I903, I found at Spirit Lake, Iowa, spermogonia and young aecidia on leaves near the ground of Aster multiflorus, with germinated teleutospores on old leaves of Stipa spartea within a few feet, and no other grass or sedge rust noticeable for a considerable distance 
about. I was unable to secure material to carry forward this suggestive observation until the season following. Teleutosporic material was obtained at Spirit Lake, Iowa, and on May 9, 1904, was sown on Aster ericoides, which gave very abundant spermogonia on May 18 , and strong aecidia on May 27. A second sowing was made on May I3 and another on May 2I, which gave marked results with Aster multiflorus and A. NovaeAngliae, but no infection with $A$. cordifolius, $A$. Drummondii, $A$. paniculatus and $A$. sericeus, although the host plants were in vigorous growing condition. The data for these sowings are as follows:

May 9, Telentospores sown on Aster cricoides; May 18, spermogonia; May 27, aecidia.

May 13. Teleutospores sown on Aster multiflorus; May 23, spermogonia; May 28, aecidia.

May 13, Teleutospores sown on Aster cordifolius; no infection.

May 21, Teleutospores sown on Aster wulliflirus; May 29, spermogonia; June 4, aecidia.

May 21. Teleutospores sown on Aster Norae Angliae; May 27, spermogonia; June 3, aecidia.

May 21. Telettospores sown on Astor Drummondii; no infection.

May 21, Teleutospores sown on Aster faniculatus; no infection.

May 21, Teleutospores sown on Aster sericeus; no infection.

The spermogonia and aecidia of this species are wholly unlil:e those of the common Care.r rust, both in general appearatice and microscopic characters. The leaves of the host are thickened and more or less clistorted by the fungus, and the aeciclia have the pustular appearance of $A E$. recedens on Solidige. AE. hemispherioum on Lactuca, and other Compositespecies having very delicate peridia, or none. The spores instead of being a bright orange-yeliow, as in most aeciclia, are decidedly brown. It is a very distinctive form, and yet I have been unable to learn of but one collection having been made. beside my own. It was found on Aster multiflorus, Bourbor. Co., Kans., May 29, 1902, by A. O. Garrett, who kindly sent me a specimen.

Finding the aecidium of Puccinia Stipae show's that the American species is wholly distinct from the European species on Stipa, which Bubak has proven by cultures belongs to an aecidium on the Labiate-genus Thymus. The aecidium does not attack all species of Aster alike, but judging from present cultural results, can be expected on the suffrutescent forms having coarse narrow leaves of firm texture. Such species may represent a natural group within the genus, but if so the taxonomists have not defined it. It is somewhat more probable that they represent an ecological group adapted to a dry atmosphere. The aecidium has not been characterized, and therefore a description is appended. 


\section{Puccinia Stipae Arth.}

0 . Spermogonia amphigenous, irregularly grouped, punctiform, brownish orange, subepidermal, globoid, $95-110 \mu$ in diameter; ostiolar filaments free, $35-50 \mu$ long.

I. Aecidia amphigenous, in irregular groups, on hypertrophied spots, brownish orange, small; peridia low, fragile and evanescent, cells abutted or slightly imbricated, smooth outside, tuberculate inside, thin walled; aecidiospores globose, $18-25 \mu$ in diameter, wall medium thick, 1-2 $\mu$, brownish yellow, closely and finely verrucose, pores many, scattered, often conspicuous.

On Aster multiflorus Ait., Iowa and Kansas, and also cultivated on $A$. ericoides L., and $A$. Novae-Angliae $\mathrm{L}$.

4. Puccinia Sorghi Schw.- Through a fortumate observation in the field, June 2, I904, upon finding aecidia on Oxalis cymosa Small, the attempt was made to grow the aecidiospores on youns corn plants, which resulted in complete success. On June 2, aecidia-bearing leaves were suspended over potted corn plants, under a large bell jar. On June io uredosori broke through the epidermis, and on July Io teleutosori began to appear. This is taken as demonstrating the genetic connection of Ecidium Oxalidis Thuem. and Puccinia Sorghi Schw.

A detailed account of this culture, with citation of all collections of the aecidium on various species of Oxalis, known to the writer, has already been published in the Botanical Gazette (38:6467. I904).

5. Peccinia Podophylu Schw.-This antoecious species of rust is very common in the vicinity of Lafayete, Ind. Leaves bearing recently opened aecidia were placed above the leaves of two potted plants on May 7. and both kept under bell-jars for three rlays. ( n May 23, one plant bevan to show telentospores, and, on May 20, the other plant exhibited many whitish spots which began to burst open and display telcutospores on May 24. Both plants proved to be heavily infected over large areas of the leaves.

The principal interest in this culture comes from the fact that the sowing of aecidiospores did not give rise to secondary aecidia. hut excluarely to the characteristic telentospores. Sylow in his Monog. Urodinearum ( $1: 526)$ states that this species has primary and secondary accidia, the former being more common and forming extended srouns, the latter coming later with the teleutospores and are sparsely distributed with few together in small groups. As many similar species of rusts have repeating aecidia, it would be natural to suppose that in this case the secondary generation arose from the aecidiospores of the first generation. The culture was made from a luxuriant development of the primary form : and from the fact that no secondary aecidia appeared, I think it can be safely assumed, that the so-called secondary generation arises, generally at least, from teleutospores, and its sparse distribution is due to the smaller number of sporidia which strike the leaf, or to 
the inhibition of maturer tissues in the leaf. So far as this culture can be taken as evidence, it shows that a true secondary generation of the aecidium probably does not occur in P. Podophylli.

\section{Summary.}

The following is a complete list of successful cultures made during the season of I904. It is divided into the two series: species previously reported by the writer or other investigators, and species now reported for the first time.

\section{A. Species previously reported.}

i. Melampsora Medusae Thuem.-Teleutospores from Populus deltoides Marsh. and P. tremuloides Michx. sown on Larix decidua Mill., and from $P$. deltoides Marsh. sown on $L$. laricina (Du R.) Koch.

2. Phragmidium speciosum Fr. - Teleutospores from Rosa Arkansana Port. sown on $R$. Arkansana Port., $R$. humilis Marsh., $R$. Carolina L., and $R$. nitida Willd.

3. Puccinia Helianthi Schw.-Teleutospores from Helianthus mollis Lam. sown on $H$. annuus L. and $H$. mollis Lam. with abundant infection, and on $H$. hirsutus Raf., $H$. occidentalis Ridd., $H$. strumosus L., and $H$. tomentosus Michx. with slight infection; from $H$. grosse-serratus Mart. sown on $H$. annuus L., and $H$. grosse-serratus Mart. with abundant infection, and on $H$. tomentosus Michx. with slight infection; and from $H$. laetiflorus Pers. sown on $H$. annuns L., $H$. lactiflorus Pers., and $H$. scaberrimus Ell. with abundant infection, and on $H$. divaricatus $\mathrm{L}$., $H$. Kellermani Britton, $H$. mollis Lam., $H$. occidentalis Ridd., and $H$. tomentosus Michx. with slight infection.

4. Puccinia subnitens Diet.-Teleutospores from Distichlis spicata (L.) Greene were sown on Chewopodium album L., Cleome spinosa L., Lepidium apetalum Willd., L. Virginicum L., Sophia incisa (Engelm.) Greene, and Erysimum asperum DC.

5. Puccinia Pammelin (Trel.) Arth.-Teleutospores from Panicum virgatum L., sown on Euphorbia corollata L.

6. Puccinia verrenicola (E. \& K.) Arth.-Teleutospores from Sporobolus longifolius (Torr.) Wood sown on Verbena urticaefolia L.

7. Puccinia Windsoriae Schw.-Teleutospores on Tricuspis seslerioides Torr. sown on Ptelea trifoliata L.

8. Puccinia Fraxinata (Schw.) Arth.-Teleutospores on Spartina cynosuroides Willd. sown on Fraxinus lanceolata Borck.

9. Puccinia Impatientis (Schw.) Arth.-Teleutospores on Elymus Virginicus L. sown on Impatiens aurea Muhl. 
io. Puccinia poculiformis (Jacq.) Wettst.- Teleutospores on Elymus Canadensis L., Agropyron tenerum Vasey and A. repens (L.) Beauv. sown on Berberis vulgaris $\mathrm{L}$.

i i. Puccinia Riramni (Pers.) Wettst.- Ecidiospores on Rhamnus lanceolata Pursh. R. Caroliniana Walt., and $R$. Cathartica L., sown on Avena sativa L.

I2. Puccinia angustata Peck.- Teleutospores on Scirpus atrozirens Muhl. sown on Lycopus Americanus Muhl.

13. Puccinia Peckin (DeT.) Kellerm.-Teleutospores on Carex lanuginosa Michx., and C. trichocarpa Muhl. sown on Onagra biennis (L.) Scop.

I4. Puccinia Caricis-Erigerontis Arth.-Teleutospores on Carex festucacea Willd. sown on Erigeron annuns (L.) Pers.

I5. Puccinia Albiperidia Arth.- Teleutospores on Carex gracillima Schw. sown on Ribes Uva-crispa L., R. Cynosbati L., and $R$. rotundifolium Michx., with a slight infection on $R$. aureum Pursh; and on C. crinita Lam. sown on $R$. Uva-crispa $L$. and $R$. rotundifolium Michx.

i6. Puccinia Polygoni-amphibi Pers.- Ecidiospores on Geranium maculatum L. sown on Polygonum emersum (Michx.) Britt.

B. Species reported now for the first time.

I. Melampsora Bigelowir Thüm. - Teleutospores on Salix amygdaloides Anders. sown on Larix decidua Mill.

2. Puccinia tomipara Trel.- Teleutospores on Bromus ciliatus L. sown on Clematis Virginiana L.

3. Puccinia Stipae Arth.- Teleutospores on Stipa spartea Trin. sown on Aster multiflorus Ait., A. cricoides L., and $A$. Novae-Angliae L.

4. Puccinia Sorghi Schw.-Acidiospores on Oxalis cymosa Small sown on Zea Mays L.

5. Puccinia Podophylli Schw.-Ecidiospores on Podophyllum peltatum $\mathrm{L}$. sown on same host.

Purdue University, Lafayette, Ind. 



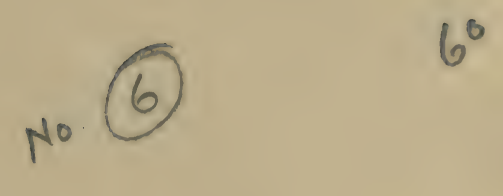

\section{CULTURES OF UREDINEAE IN 1905}

By J. C. ARTHUR. 



\title{
62
}

Reprinted from the Journal of Mycology, 1:11-27 January 1906

\section{CULTURES OF UREDINEAE IN $1905 .^{1}$}

\author{
BY J. C. ARTHUR.
}

The present article forms the sixth of a series of reports ${ }^{2}$ by the author upon the culture of plant rusts. They cover the years from 1899 to the present year, inclusive. In these studies the grass and sedge rusts hold a prominent place, but other heteroecious and autoecious species have been included, and during the present season the work has been extended to the so-called opis, micro and lepto forms, and also to species with amphispores.

The coöperative agreement between the Bureau of Plan Industry of the U. S. Department of Agriculture and the Indiana Experiment Station, which existed for carrying on the culture work in the spring of 1904, was again established, extending from July, I904, to April 30, 1905, making it possible to have an assistant during this period, who devoted nearly his whole time to the study of the rusts. The position was first held by Mr. J. C. Marquis, who was succeeded on October I, I905, by Mr. Frank D. Kern, and after the expiration of the coöperative agreement Mr. Kern was retained by the Experiment Station to continue the work. After May ro all the work fell upon $\mathrm{Mr}$. Kern until September, covering the most important part of the culture period, the author being absent in Europe. It could not, however, have been entrusted to better hands, as the fine ability displayed in the work during the previous season, coupled with considerable experience already acquired, enabled him to meet the new conditions as they arose, and the judgment and caution indispensable in securing authoritative results.

Much of the completeness of the work is due to the kindly assistance of correspondents, who have sent teleutosporic material, and especially to Messrs. E. Bethel, Denver, Colo.; J. M. Bates, Red Cloud, Neb.; A. O. Garrett, Salt Lake City, Utah;

${ }^{1}$ Read before the Botanical Society of America at the New Orleans meeting, January $1,1906$.

See Bot. Gaz. 2Q:268-276; Jour. Mycol. 8:51-56; Bot. Gaz. 35 : 10-23; Jour. Mycol. IO: 8-21 and II : 50-67. 
J. J. Davis, Racine, Wis. ; E. Bartholomew, Rockport, Kansas; H. H. Whetzel and H. S. Jackson, Ithaca, N. Y.; C. L. Shear and P. L. Ricker, Washington, D. C.; Wm. J. Horne, Santiago de las Vegas, Cuba; Jos. J. Wolfe, Durham, N. C. ; Lewis Kaufman, Morrison, Iowa; R. D. Echlin, Washington, Iowa; R. E. Buchanan, Ames, Iowa; H. L. Bolley, Fargo, N. D. ; and H. L. Shantz, Lincoln, Neb.; to whom my warmest thanks are extended. I am also much indebted to Messrs. Bethel and Garrett for rooted wild plants on which to make sowings, and to Dr. Davis for field observations and the suggestion which led to successful sowings of Puccinia Eleocharidis.

During the present season 85 collections of material with resting spores and 15 collections with active spores were employed, from which 484 drop cultures and I3 Petri dish cultures were made to test the germinating condition of the spores, these being made almost wholly from the resting spores. Out of the 85 collections with resting spores 32 could not be made to germinate, although every condition seemed favorable, and were therefore useless. There were in all 194 sowings of spores made, representing 45 species of rusts, and for this purpose Ioo species of hosts were utilized, which were grown temporarily in pots in the greenhouse.

A few cultures were made with heteroecious species for which no clue to the alternate host had been obtained, and with one exception the results were negative. These negative trials are here recorded to serve for reference.

I. Puccinia on Carex Pennsylvanica, sent by Rev. J. M. Bates from Red Cloud, Neb., was sown on Urtica gracilis with no infection. Similar material in former seasons has been tried on twenty-one other species of hosts with negative results. ${ }^{3}$

2. Puccinia emaculata Schw. on Panicum capillare L. from Lafayette, Ind., was sown on Ambrosia artemisiaefolia, Rudbeckia triloba, $R$. laciniata and Steironema ciliatum, with no infection. This very common and distinctive rust was sown in former seasons on fourteen other species of hosts with negative results. ${ }^{4}$

3. Puccinia tosta Arth., on Sporobolus asperifolius, sent from Denver, Colo., by Mr. E. Bethel, was sown on Napaea dioica Symphoricarpos racemosus, Xanthoxylum Americanum, Aesculus glabra and Viola papilionacea, with no infection. Sowings of what is taken to be the same species of rust, but on

See Jour. Mycol. ro:10. 1904; and IT:51. 1905.

"See Jour. Mycol. 8: 52. 1902; Bot. Gaz. 35:12. 1903; and Jour. Mycol, Io: 10. 1904 . 
another host, were made in 1903 on six other species of hosts with negative results. ${ }^{\circ}$

4. Puccinia Crandalli Pamm. \& Hume, on Festuca confinis, sent from Boulder, Colo., by $\mathrm{Mr}$. E. Bethel, was sown on Dodecatheon Meadia, Hydrophyllum appendiculatum, Aquilegia Canadensis, Anemone Canadensis, Thalictrum dioicum, Rudbeckia triloba, Gutierrezia Sarothrae, and Lonicera Japonica, with no infection.

5. Uromyces graminicola Burr. on Panicum virgatum, sent from Red Cloud, Neb., by Rev. Bates, was sown on Psoralea Onobrychis, with no infection; while similar material sent by Mr. Bartholomew from Stockton, Kans., was sown on the same host and also on Cassia Chamaecrista, Polemonium reptans and Rudbeckia laciniata, all with no infection.

6. Uromyces Junci (Schw.) Tul. on Juncus effusus, sent by Mr. Jackson from Ithaca, N. Y., was sown on Rudbeckia laciniata, $R$. triloba, and Falcata comosa, with no infection. What is believed to be the same species of rust, but on another host, was sown in 1902 on a species of Iris with negative results.

The following species of rusts were successfully grown, and the data supplement that obtained from previous cultures of this series, or that published by other investigators obtained by means of similar cultures. The results in connection with Puccinia Pruni-spinosae, the plum rust, are especially interesting, being the first studies of the kind with American material.

I. Melampsora Medusae Thuem.-Teleutosporic material obtained near Lafayette, Ind., on Populus deltoides was sown April I7 on Larix laricina and $L$. decidua, which resulted in abundance of spermogonia appearing April 25, and a greater abundance of aecidia May I, upon both hosts. ${ }^{\circ}$

2. Gymnosporangium Juniperi-Virginianae Schw.Three samples of teleutosporic material were used, one from the eastern states, and two from the central west. The test was designed to show whether any difference existed between the two regions in the power of the species to infect the cultivated apple; the apple orchards of Iowa and the central west generally being well known to be especially free from this rust. All the teleutosporic material was on Juniperus Virginiana, and to all appearances equally good. That sent from Durham, N. C., by Mr. Wolfe, was sown on a seedling apple out of doors April 27, and showed abundant spermogonia May 9, but did not develop

See Jour. Myc. Io: 10. 1904.

- See Jour. Mycol. IO: 13. 1904; and $I I: 52.1905$. 
aecidia, although conditions appeared favorable. Material from Washington, Iowa, sent by Rev. Echlin, was sown April 22, on a small plant of the York Imperial apple in the greenhouse, and showed abundant spermogonia on May 5 ; another sowing was made out of doors on a seedling apple April 27, and showed spermogonia on May I3, but further observation was prevented by insect depredation. A second lot of material was received from Ames, Iowa, sent by Mr. Buchanan, and was sown out of doors on seedling apple and Crataegus coccinea, and in the greenhouse on Amelanchier Botryapium. The sowing on apple gave abundant spermogonia, but failed to make further development, while on the other hosts there was no infection. So far as these tests go there appears to be no difference between the eastern and western forms of the species in their power to infect the cultivated apple. Many cultures have been made showing the full life cycle of this rust (often called G. macropus). A good summary of the subject, especially in reference to the question underlying the present work, was given a short time ago by Professor Pammel $^{7}$ of the Iowa State College.

3. Puccinia Sambuci (Schw.) Arth.-Teleutosporic material of fine quality on Carex lupulina, collected in Noble county, near Beavor Dam, Ind., was sent by Mr. Whetzel. It was sown on Sambucus Canadensis May 8, giving rise to abunIdant spermogonia May 14, and aecidia May 25.

4. Puccinia albiperidia Arth. - Teleutosporic material was gathered near Lafayette, Ind., on Carex tetanica, and sown April 7 on Silphium perfoliatum, Polemonium reptans, Ambrosia trifida, Rudbeckia laciniata, Steironema ciliatum, and Ribes gracile. Only the last host showed infection, giving abundant spermogonia April I4, and aecidia April 27, the others remained entirely free from rust.

A part of the teleutosporic material was sent to Dr. H. Klebahn, Hamburg, Germany, who sowed it on Ribes Uva-crispa, $R$. aureum and $R$. rubrum. No infection resulted on $R$. rubrum, but on $R$. Uva-crispa spermogonia showed May 8 , and on $R$. aureum May 15. The further development, however, was slow, soon coming to naught in the first case, and persisting much longer, but with little advance in the second case. Dr. Klebahn in commenting upon his results says that the imperfect development of the infection on $R$. $u v a$-crispa may be ascribed, in part at least, to the late sowing, for the teleutospores germinated freely. The host plants had already passed the most active period of growth, and the weather was too warm. His results are exactly in accord with our own under similar conditions. The

${ }^{7}$ Bull. Iowa Exper. Sta., No. 84:16-24. August, 1905. 
iaiture to secure good aecidia made it impossible to give an oppinion on the identity of this species of rust, ${ }^{8}$ as compared with European forms.

5. Puccinia Caricis-Solidaginis Arth. - Teleutospores on Carex sparganioides gathered near Lafayette, Ind., were sown April 22 on Aster paniculatus and again on May II on A. paniculatus, A. Drummondii, Ribes rotundifolium, Urtica gracilis, and Solidago Canadensis. No infection occurred except on the last host, this giving spermogonia May 18 and aecidia May 28 in very great abundance. In 1902 cultures of this species were made with teleutospores taken from Carex Jamesii and C. stipata. ${ }^{9}$

6. Puccinia Peckir (DeT.) Kellerm. - Teleutosporic material on Carex lanuginosa, gathered at Red Cloud, Neb., by Rev. Bates, was sown May 19 on Hydrophyllum appendiculatum, Steironema ciliatum, and Onagra biennis. On May 26 spermogonia, and May $3 \mathrm{I}$ aecidia appeared on $O$. biennis, the other hosts remaining entirely unaffected. This result is a duplicate of that obtained in $1904 .{ }^{10}$.

7. Puccinia Caricis (Schum.) Reb. - Teleutosporic material on Carex stipata, gathered near Lafayette, Ind., was sown April 18 on Urtica gracilis, and gave spermogonia April 24, and aecidia May $\mathrm{I}$, in great abundance.

A collection in excellent condition made at Denver, Colo., by Mr. Bethel, on Carex aquatilis, was sown on Urtica gracilis April Io, giving few but well developed spermogonia April I8, and numerous aecidia April 29. It was sown again April 25, and gave abundant spermogonia May I, followed with very numerous aecidia May 8.

Both of these sowings were tried on the evidence of the microscopic examination of the collections. It was found that the medium-sized teleutospores, and large uredospores found intermixed, agreed with those known to belong to this species, and the results confirmed the diagnosis. Both collections give new hosts for the species. ${ }^{11}$ More interesting still was the presence in the Colorado collection of abundant amphispores, which agree in every particular with those collected on Carex stricta by C. H. Peck in New York, distributed in Thuemen's Myc. Univ., No. 746, and first called Uromyces Caricis Pk., then Puccinia Caricis-strictae Diet. This fortunate collection enables us to show beyond a reasonable doubt, that the Uromyces Caricis

${ }^{8}$ For record of previous cultures see Jour. Myc. 8:53. 1902; 10: 11. 1904 ; and $I I: 58.1905$.

See Bot. Gaz. 35:21. 1903.

"Jour. Mycol, $I I: 58.1905$.

${ }^{11}$ For previous cultures see Bot. Gaz. 29:279. 1900; 35:16. 1903; and Jour. Mycol. 8:52. 1902. 
of Peck is the amphisporic form of Puccinia Caricis. What determines the production of amphispores in this species is an interesting question, in view of the fact that only twice have they been found, and at such a great distance apart. The amphispores in the Colorado collection did not germinate in drop culture, although the same conditions gave fine germination of the associated teleutospores.

8. Puccinia fraxinata (Schw.) Arth. - A collection of teleutospores on Spartina cynosuroides, sent by $\mathrm{Mr}$. Bartholomew from Hill City, Kans., was used to sow April 29, on Fraxinus lanceolata, Adelia acuminata and Ligustrum vulgare. Only the first host gave results, showing spermogonia May 5, and aecidia May I4, the sowing being made on a cut branch placed in water in the greenhouse. ${ }^{12}$

9. Puccinia amphigena Diet.-Teleutosporic material on Calamovilfa longifolia sent by Rev. Bates from Red Cloud, Neb., was sown on Smilax hispida May 27, and began to show spermogonia June 2 , and aecidia June 10, both in abundance. ${ }^{18}$

io. Puccinia verbenicola (E. \& K.) Arth.-Teleutosporic material on Sporobolus longifolius, sent from Red Cloud, Neb., by Rev. Bates, was sown on Verbena urticaefolia May 3, and showed spermogonia May 9, and aecidia May 20. Another collection on same host, obtained near Lafayette, Ind., was sown on same species of Verbena May 27, and showed spermogonia June 2, and aecidia June Io. ${ }^{14}$

i i. Puccinia pustulata (Curt.) Arth. - Teleutosporic material on Andropogon furcatus, gathered by the writer at English Lake, Ind., was sown on Pentstemon hirsutus and Comandra umbellata May 27, with no infection of the Pentstemon, but abundant growth on the Comandra, spermogonia appearing June 2 , and aecidia June I4. This result confirms work done in I9O3. ${ }^{15}$

i2. Puccinia Pammelit (Trel.) Arth. - The cultural results of $1904^{16}$ were verified by sowing teleutospores from Panicum virgatum, obtained by the writer at English Lake, Ind., uponEuphorbia corcllata. A sowing was made May 26, giving spermogonia June 2, and aecidia June 9.

I3. Puccinia subnitens Diet. Teleutosporic material on Distichlis spicata, sent from Red Cloud, Neb., by Rev. Bates, was

${ }^{12}$ For previous cultures see Bot. Gaz. 29:275. 1900; and Jour. Mycol. II : 57. 1905.

${ }^{13}$ For previous cultures see Bot. Gaz. 35:20. 1903; and Jour Mycol. IO: 11 . 1904 .

${ }_{14}$ For previous cultures see Bot. Gaz. 29:274. 1900; 35:16. 1903; and Jour Mycol. II: 56.1905.

${ }_{15}$ Jour. Mycol. 10: 17. 1904.

${ }^{16}$ Jour. Mycol. II : 56.1905. 
sown on Erysimum asperum, Sophia incisia, ${ }^{17}$ Lepidium Virginicum, and Bursa Bursa-pastoris, with success in each case. The sowing was made April 18, and spermogonia appeared on Eryisimum and Sophia April 25, Lepidium April 26, and Bursa April 27, while aecidia were observed on all by May 8 . The aecidia develop with considerable difficulty on Bursa, and Rev. Bates writes that they are not common or abundant in the field on this host. On Lepidium they also start with less ease than on the other species, but under good conditions grow well. ${ }^{18}$

I4. Puccinia poculiformis (Jacq.) Wettst. - Teleutosporic material on Agrostis alba, sent from Ithaca, N. Y., by Mr. Jackson, was sown on Berberis vulgaris April I3, and showed numerous spermogonia April 22, with abundance of aecidia May 4.

I5. Puccinia Sorghi Schw. - The work of last year, ${ }^{10}$ in which only aecidia were used, was verified this season by sowing teleutospores. The material was obtained in Lafayette from an early garden variety of sweet corn. It was sown April 17 on Oxalis cymosa (the common wild wood sorrel of the region), O. Ortgiesii (a yellow-flowered greenhouse weed), O.(a tuberous pink-flowered form of greenhouses), and $O$. Bowiei (a pink-flowered form with large flowers and leaves, also grown in greenhouses.) All remained free, except $O$. cymosa, which showed numerous spermogonia on April 27, and aecidia on May 5. A second sowing was made May I on $O$. cymosa, O. Origiesii, $O$. Bowiei, and $O$. corniculata (growing out of doors over a grasscovered conduit for steam pipes), and again all remained free except $O$. cymosa, which gave spermogonia May 8, and eacidia May 14. It is not apparent why no infection should occur on the four hosts other than $O$. cymosa, but there is no reason to suppose that it was due in any degree to lack of vigor or suitable conditions.

The aecidiospores raised in the first trial above were sown May 6 on seedlings of the yellow dent field corn variety of Zea Mays, and in a week, May I3, showed uredospores, which increased in abundance until teleutospores were observed June I5. The uredospores from this culture (on yellow dent corn) were sown May i6 on small plants of garden sweet corn, and gave

${ }^{17}$ This is probably not the correct name of the plant used for the cultures. It is, however, the name also used last year for the trial host, which is the common species of Sophia in this region, and the error in determination is due to the confusion existing in the current manuals. The species is also different from the one on which the fungus was collected last year in Nebraska by Rev. Bates (Jour. Mycol. II:116. 1905), and that is also incorrectly named. But for the sake of simplicity the name $S$. incisa will be used in this article for both species.

${ }_{13}$ For previous cultures see Bot. Gaz. 35:19. 1903; and Jour. Mycol. $I I: 54.1905$.

${ }^{10}$ Bot. Gaz. 38:64. 1904. 
uredospores in plenty on May 23, and would doubtless have been followed by teleutospores in due time, had the culture been continued. These results in transferring the rust from field corn to sweet corn, and the reverse, are in accord with those obtained by Kellerman. ${ }^{20}$

At the same time the first sowings were made, April I7, teleutospores were also sown on a seedling Zea Mays, under favorable conditions, but no infection resulted. The drop cultures, which are made just previous to every sowing, showed that the teleutospores germinated freely, but the few uredospores intermixed were not viable. In this case, at least, the teleutospores appeared to be incapable of infecting the host from which taken, and in so far agree with the general rule regarding grass and sedge rusts.

16. Puccinia Polygoni-Amphibir Pers. - In $1904^{21}$ it was possible to verify in a measure the work upon this species by Dr. Tranzschel of St. Petersburg, by sowing aecidiospores fromGeranium maculatum and obtaining teleutospores on Polygonum emersum. This season the reverse order of sowing was tried. Teleutospores from $P$. emersum obtained in this vicinity were sown April i5 on G. maculatum and G. Robertianum, with no infection of the latter, but most abundant infection of the former, showing spermogonia April 23 and aecidia May I. A second sowing was made April 27, using the above two hosts and also $G$. pusillum, and again infection occurred only upon $G$. maculatum, which showed great numbers of spermogonia May 3, and aecidia May 9. These results agree with common observation, for the aecidium on G. maculatum ( $A$. sanguinolentum Lindr.) is common in the United States, while no aecidia have yet been reported on G. Robertianum or G. pussillum.

i7. Puccinia Helianthi Schw.-A sowing of teleutospores, taken from Helianthus grosse-serratus growing on the grounds of the University, was made May I7 on H. grosse-serratus and two plants of $H$. annuus with equally abundant results in each case, spermogonia showing May 25, and aecidia June 2.

18. Puccinia lateripes B. \& Br. - After many vain attempts to secure good fungous and host material of this species for culture work, the present season's excellent results have given much satisfaction. All the material was obtained near Lafayette, Ind. Sowings of teleutospores from Ruellia ciliosa were made April 25 on both $R$. ciliosa and $R$. strepens, with equally positive results in both cases, showing spermogonia May 5, and aecidia May I8. Another sowing of the same material was made on $R$. strepens May 27, which gave spermogonia June 5 , and aecidia

${ }^{20}$ Cf. Jour. Mycol. II: 27. 1905.

${ }^{21}$ Jour. Mycol. 11 : 59.1905. 
June 15 . A sowing of teleutospores from $R$. strepens on $R$. ciliosa May 8, and another June 7, gave no infection.

Many writers, following Lagerheim, who received his clue from Burrill, have made two species of the rusts on these two hosts. It is true that the gross appearance, and to some extent the microscopic characters of the two are perceptibly different. These differences are shown, so far as the development went, in the results of the cultures. The aecidial groups grown on $R$. ciliosa were small and round, one to two millimeters across, without noticeable hypertrophy of the tissues, and confined to the blade of the leaf. On $R$. strepens, however, they took possession of the veins, petioles and stems, and made large swellings from 20 to 25 millimeters long, and in one case the main steam for a distance of ten centimeters or more was greatly swollen and distorted. The differences also extended to the peridial cups and to the spores. On $R$. ciliosa the cups were mostly one-half millimeter high, and on $R$. strepens fully one millimeter high. The aecidiospores from $R$. ciliosa measured $15-19$ by $20-26 \mu$, and from $R$. strepens $\mathrm{I} 7-2 \mathrm{I}$ by $24-30 \mu$. These two cultures were from the same source of infection, and must therefore be one and the same species. Had uredospores and teleutospores been raised, it is believed that the differences recorded in the books for the two hosts would have been found. In short it is believed that the differences of size and appearance are entirely due to the influence of the hosts. The loose, somewhat succulent tissues of $R$. strepens, and its vigorous habit of growth, are correlated with the greater development of the fungus, while the firm close tissues of $R$. ciliosa, not only prevent luxuriant development of the parasite, but its parts become smaller throughout. These differences in the hosts also account for the failure to infect $R$. ciliosa with spores from $R$. strepens, while the reverse process succeeded. There appears to be no reason to doubt that under very favorable conditions the infection of $R$. ciliosa with spores from $R$. strepens could be accomplished, and the resulting development be the same as when the infecting spores came from $R$. ciliosa itself. ${ }^{22}$

19. Puccinia Pruni-spinosae Pers.-The Aecidium punctatum Pers. ( $A$. quadrifidum DC.) occurring in various parts of the United States and Canada on different species of Ancmone, Hepatica and Thalictrum so closely resembles the European form which bears the same name, that little doubt has existed of their genuine identity. In 1904 Dr. Tranzschel ${ }^{23}$ of St. Petersburg made cultures of this aecidium, sowing the aecicliospores from Anemone coronaria on Amygdalus communis (almond) Prunus spinosa (blackthorn), P. divaricata (cherry-

For previous cultures see Kellerman in Jour. Mycol. 9:107. 1903.

23 Trav. Mus. Bot. Acad. Sci. St. Petersb. II:67-69. 1905. 
plum) and from Anemone ranunculoides on $P$. spinosa, producing in each the characteristic uredospores of Puccinia Prunispinosae, the rust of plums and peaches.

This work by Dr. Tranzschel suggested the following trials with American material. Aecidiospores from Hepatica acutiloba (Aecidium hepticatum Schw.) were sown on three small plants of Prunus serotina (wild black cherry), established in pots in the greenhouse, on Prunus Americana (native plum), P. Cerasus (cultivated cherry), and Amygdalus Persica (peach), the last two seedlings. The sowings were made May I to 4, and in fifteen days afterward, uredospores appeared on $P$. serotina, but the other plants remained wholly free, watch being continued for a month and more. The successful sowings were as follows:

May 1, Aecidiospores sown on P. serotina; May 16, uredospores; May 22, teleutospores.

May 1, Aecidiospores sown on P. serotina; May 16, uredospores.

May 2, Aecidiospores sown on $P$. serotina; May 17 , uredospores.

On May 23, a sowing of uredospores, which had been grown on $P$. serotina, was made on $A$. Persica, under seemingly most favorable conditions, but no infection took place, watch being kept for two months.

From these results there can be no further question of the general identity of the American and European plum and cherry rusts, and their connection with the Aecidium punctatum. It is not possible to state what significance is to be attached to the failure to infect peach, plum and cultivated cherry with spores that readily infected the wild cherry. Careful search for two seasons in the vicinity of the diseased hepaticas, the fungus being perennial, has failed to detect any rust on plums, cherries or peaches, wild or cultivated, although growing in plenty; and furthermore Puccinia Pruni-spinosae has not yet been reported from Indiana, although said to occur in the adjoining state of Illinois on $P$. serotina, $P$. Virginiana, and $P$. Americana.

20. Puccinia Xanthi Schw. - Teleutosporic material on Xanthium Canadense, gathered near Lafayette, Ind., on Nov. 5 , I904, was sown on the second and third leaves of seedlings of the same species of host April 3. On April 8 small yellow dots began to show, which closely simulated spermogonia, but which microscopic examination by means of sections proved were only the very young teleutosporic sori. The yellow dots increased in size, appearing like small pimples, and finally broke through the epidermis, exposing the teleutospores April 2I, eighteen days after inoculation. Another sowing was made April I3, on the cotyledons of the same species of host, and on the second leaves of Ambrosia trifida. The Xanthium seed-leaves showed yellow dots on April 22, and open sori May I, also in eighteen days from sowing, but the Ambrosia leaves remained free. 
These results agree essentially with those reported by Carleton, ${ }^{24}$ who was able to infect Xanthium in eighteen and fourteen days, but could not infect Ambrosia. He says, however, that "in all these cases spermogonia preceded the teleutospores in the infected spots." In connection with an account of cultures with Puccinia heterospora he adds that "numerous experiments were also made with other lepto species, including Puccinia Grindeliae Pk., P. variolans Hark., P. Lygodesmiae E. \& E., and P. Sherardiana Korn., with results similar to those above mentioned," but he does not report the details of these cultures, if such they were.

Taking the observations here recorded for $P$. Xanthii, especially in connection with those for $P$. Silphii and $P$. Grindeliae, reported below, it seems safe to assume that these species, and those quoted as mentioned by Carleton, belong to a group of rusts in which teleutospores and their resulting sporidia are the only spore-forms produced in the life-cycle, aecidia, uredo, and even spermogonia being wholly absent.

The following nine species have never been tested before by the culture method, so far as the writer knows, either in this country or abroad. They embrace an interesting diversity of habit. Besides the grass and sedge forms, with which this series of cultures has been most concerned, there are two leptopucciniae, one micropuccinia and one brachypuccinia, also one of the grass rusts is chiefly interesting for its amphispores.

I. Puccinia Silphin Schw. - Teleutosporic material was gathered March 3I, 1905, near Lafayette, Ind., on dead and weathered leaves of Silphium integrifolium, and sown April ro on vigorous plants of the same host, and also on $S$. perfoliatum. There was no infection on the latter host, but on the former clear yellow dots showed April 15, which sectioned and placed under the microscope proved to be very young teleutosori. These yellow dots rapidly enlarged, forming pale pimples scattered over yellow patches of the leaf, with much hypertrophied tissues, and April 20 broke through the epidermis, exposing the abundant teleutospores. Another sowing on the same two hosts was made April 25, and with the same results: there was no infection of $S$. perfoliatum, and the most abundant infection of $S$. integrifolium, showing as yellow dots May 2, and exposed teleutospores May 5. As the rust occurs on both these species of Silphium, and many others as well, the results may be taken as indicative of biological races.

2. Puccinia Grindeliae Pk. - Excellent teleutosporic material on Gutierrezia Sarothrae was sent by Mr. Bethel, collected

^ Bulletin Bureau Pl. Industry, No. 63:26. 1904. 
at Boulder, Colo., March 27, 1905, on weathered stems. Mr. Bethel also kindly sent growing plants of the host and of Chrysothamnus nauseolus. The latter is not a recorded host for $P$. Grindeliae, but for a similar species, P. tuberculans E. \& E. A sowing was made on $G$. Sarothrae April 12, which showed yellow dots April 2I, and numerous open teleutosori May 2. Another sowing was made on both hosts April 26, with no infection on C. nauseolus, but most abundant infection on G. Sarothrae, showing yellow dots May 4, and open teleutosori May I5. The yellow dots were investigated, as in the other instances, and found to be the early stages of teleutosori, with no trace of spermogonia.

3. Puccinia Solidaginis Pk. - Teleutosporic material was sent by Mr. Garrett, collected at Salt Lake City, Utah, on Solidago trinervata, April 8, 1905. It was sown on S. Canadensis May I7, showing yellow dots June 2, and an abundance of open teleutosori June 7 , with considerable hypertrophy of the tissues. Although the yellow dots were not specially investigated, they gave the same appearance of being young sori, as in the above. species of leptopucciniae.

4. Puccinia transformans E. \& E.-Remarkably fine teleutosporic material, forming considerable excrescences on leaves and stems of Stenolobium Stans (Tecoma Stans), was. sent by Mr. Horne, who collected it at Santiago de las Vegas, Cuba, May 3, 1905. It was sown on two young plants of $S$. Stans May 13, and in both cases gave abundance of spermogonia May 29, and of teleutospores June 5 .

Fine material gathered by Mr. J. B. Rorer on the pods of $S$. Stans in the Bahama Ids., at Nassau, New Providence, March, 1904, was sent for identification. The pods contained many seeds, which were planted in the greenhouse, and provided the host plants for the above inoculations. The teleutospores of this collection were in good germinating condition. As there were no growing plants of S. Stans at hand, they were sown May 20 (1904) on vigorous young plants of Campsis radicans (Tecoma radicans), but gave no infection, although the conditions seemed particularly favorable.

Since the cultures were made a study of the characters of the species has been undertaken, and the conclusion reached that all North American collections, so far as known, belong to $P$. transformans ( $P$. exitiosa Syd. \& Holw.). An original specimen of $P$. transformans, collected in Baja California by $\mathrm{K}$. Brandegee in I893 on Tecoma Stans, has been examined, and found to agree with other specimens on the same host from the West Indies, and also with the type material of $P$. exitiosa on Tecoma mollis, that is Stenolobium mollis, from Mexico. The species possesses considerably smaller spores, with thinner walls and finer sculp- 
turing, than Puccinia elegans Schröt., reported only from Argentine, South America, an original specimen of which I have been able to examine through the courtesy of Dr. P. Hennings of the Botanical Garden, Berlin. P. transformans has not yet been reported from any locality in the United States.

5. Puccinia Kuhniae Schw. - Teleutosporic material, gathered near Lafayette, Ind., Nov. 3, 1904, on Kuhnia eupatorioides, was sown on the same host May I9. On May 28 spermogonia appeared sparingly, which were examined under the microscope in section, and these were followed June 5 by uredo in fair abundance. The species, therefore, belongs to the group of brachypuccinia.

6. Puccinia canaliculata (Schw.) Lagerh. - An observation in the field made in I9O4 led to the present successful cultures. Aecidia were found in remarkable abundance on seedling Xanthium Canadense over an area 8 to 10 meters in diameter, beyond which the aecidium did not occur, although the hosts were equally plentiful and equally exposed. Later in the season, the middle of June, uredosori were found upon what appeared to be a seedling sedge extending over approximately the same area that had been occupied in the spring by the cocklebur cluster cups, and this was followed in August by teleutosori. Although the sedge did not fruit, yet it was not difficult to ascertain that it was a species of Cyperus, and the rust Puccinia canaliculata.

On May II a sowing of aecidiospores, obtained from the locality mentioned, was made in the greenhouse on Cyperus esculentus, other species of the genus not being at hand, and on June 2 uredo were noticed, although they probably appeared earlier and were overlooked, being small and pale. Another sowing was made on the same species of host May 17 , and uredo first noticed June 2. The plants did not grow well, and the infected leaves were removed for the herbarium before time enough had elapsed in which to develop telutosori. Cultures with teleutosporic material will doubtless confirm this association of the Xanthium and Cyperus rusts.

7. Puccinia Eleochardis Arth.- Teleutosporic material on Eleocharis palustris was sent by Dr. Davis from Racine, Wis., and with it the information that from observations in the field he believed this to have its aecidial phase on Eupatorium. Acting upon this suggestion, a sowing was made May 5 on Eupatorium perfoliatum, which gave rise to spermogonia May I3, and aecidia May 22. Another sowing on the same species of host May II, gave spermogonia May 20, and aecidia May 30. Both trials produced an abundance of aecidia, with all the characteristics of the common and widely distributed form on this host, and closely related species. 
8. Puccinia substerilis E. \& E. - Fine material on Stipa viridula collected in August, 1904, at Boulder, Colo., was sent by $\mathrm{Mr}$. Bethel, who also sent living plants of $S$. viridula and $S$. comata. This material showed a great abundance of amphispores, ${ }^{25}$ but almost no teleutospores. The amphispores gave good germination, and were sown April 6 on $S$. viridula and $S$. comata. Uredospores of the usual kind began to appear on $S$. viridula April 18, but no infection on S. comata. Another sowing was made April 22 on $S$. comata, which also gave no infection. Uredospores continued to form for a month on $S$. viridula, but no amphispores or teleutospores were produced.

Mr. Bethel also sent fine teleutosporic material on Stipa comata, collected in March, I905, at Boulder, Colo. This was sown on Aster ericoides April 18, and contrary to expectation gave no infection. When the failure became assured, it was sown again, April 29, on $A$. ericoides, $A$. multiflorus, and $A$. Novae-Angliae, but in each case without infection. This negative result throws some doubt on the assumption that the American Stipa rusts on the several species of hosts belong to one species, having its aecidia on certain species of Aster, ${ }^{26}$ and the present very incomplete report is therefore entered under the name $P$. substerilis. Reducing this name to a synonym of $P$. stipae, as the writer did a few months since, ${ }^{27}$ is now believed to have been premature.

9. Puccinia Seymouriana Arth. - At the time this species was published, ${ }^{28}$ it was suggested upon grounds of spore resemblance that its Aecidium was $A$. Cephalanthi Seym. From combined morphological and geographical data I was then willing to assert that "although cultures must be awaited, yet there can be little doubt that the early stages of $P$. Seymouriana occur upon Cephalanthus." Persistent efforts to secure material for this trial were finally rewarded by the writer finding especially good teleutospores on Spartina cynosuroides at English Lake, Ind., in the northern part of the state, in March, I905. These were sown on Polygala Senega April 20, with no infection, and later on Cephalantinus occidentalis, May $\mathrm{I} 3$, with abundant results. On May 18 great numbers of spermogonia began to show, and on May 27 still greater numbers of aecidia, thus verifying the prediction made three years before.

io. Uromyces acuminatus Arth. - Finding the aecidium of this very common rust was due to a fortunate accident. Of the many trials to find the connection between the two phases

${ }^{25}$ For description and illustrations of the amphipores in this species see Bull Torr. Bot. Club 32:38. 1905.

${ }^{28}$ For cultures of Puccinia Stipae see Jour. Mycol. II:63. 1905.

${ }^{27}$ Tour. Mycol. II: 11.1905.

${ }^{23}$ Bot. Gaz. 34:12. 1902. 
of a heteroecoius rust, during my seven years of experimental work, this is the first instance of success without the aid of some probable clue, and in this case may be ascribed to good luck and the exuberant enthusiasm of Mr. Kern, who made all the sowings of the season.

Teleutosporic material on Spartina cynosuroides, collected at Palmer, Neb., by Rev. Bates, was sown May 26, on whatever plants were available in the greenhouse, that are recorded as bearing aecidia of unknown teleutosporic connection. These hosts were: Polemonium reptans, Polygala Senega, Cassia Chamaecrista, Psoralea Onobrychis, Rudbeckia laciniata, Ambrosia artemisiaefolia, Thalictrum dioicum, Viola papilionacea, and Steironema ciliatum. To our great surprise $S$. ciliatum began to show spermogonia June $I$, and abundant aecidia June 6 , all others having no infection. Another sowing was at once made, June 2, which likewise gave spermogonia June 7 , and aecidia June 12.

The aecidium on this host is recorded or known to the writer from Iowa, Illinois, Nebraska, Kansas, Wyoming and Minnesota. A collection made in Wisconsin ${ }^{20}$ on $S$. lanceolatum is thought by Burrill ${ }^{30}$ to be specifically distinct. Schlechtendahl's name, Caeoma Lysimachiae, sometimes used for American specimens, was founded on an aecidium on L. thyrsiflora L. (Naumburgia thyrsiflora (L.) Duby) from vicinity of Berlin, and doubtless is entirely distinct from American forms, with the possible exception of the reference in Farlow \& Seymour's Host Index, ${ }^{31}$ the basis for which is unknown to the writer. Schweinitz's name ${ }^{82}$ Aecidium Lysimachiae applies to the form on Lysimachia quadrifolia and L. terrestris, only reported from North Carolina, and may well be considered distinct. What is now much needed is teleutosporic material from the Atlantic and Gulf coasts to be used in cultures for testing the above points, and in general the question whether the eastern and western forms are one species or not.

The great prevalence of this rust on Spartina, and the comparative rarity of the aecidia on Steironema, is doubtless due in part to the hardiness of the uredospores, which enable them to live over winter and start the uredostage in the spring under favorable conditions. This is the opinion expressed by $\mathrm{Mr}$. Bartholomew in a recent interview, and is my own opinion, founded in part upon finding uredosori upon young blades of Spartina only a few inches long at such an early date in spring that infection by means of aecidiospores seemed highly improbable.

Trelease, Paras. Fung. Wis. p. 30.

${ }^{80}$ Burrill, Paras. Fung. Ill., I. Uredineae, p. 233.

L. c. p.75. 1890.

Schrift. d. nat. Ges. Leipzig $I: 67.1822$. 


\section{SUM MARY.}

The following is a complete list of successful cultures made during the season of I904. It is divided into the two series: species previously reported by the writer or other investigators, and species now reported for the first time.

\section{A. Species previously reported.}

I. Melampsora Medusae Thuem. - Teleutospores from Populus deltoides Marsh. sown on Larix laricina (DuR.) Koch.

2. Gymnosporangium Juniperi-Virginianae Schw.-Teleutospores from Juniperus Virginiana L. sown on Malus Malus (L.) Britt.

3. Puccinia Sambuci (Schw.) Arth. - Teleutospores from Carex lupulina Muhl. sown on Sambucus Canadensis L.

4. Puccinia albiperidia Arth. - Teleutospores from $\mathrm{Ca}$ rex tetanica Schk. sown on Ribes gracile Michx.

5. Puccinia Caricis-Solidaginis Arth. - Teleutospores from Carex sparganioides Muhl. sown on Solidago Canadensis L.

6. Puccinia Peckil (DeT.) Kellerm. - Teleutospores from Carex lanuginosa Michx. sown on Onagra biennis (L.) Scop.

7. Puccinia Caricis (Schum.) Reb. - Teleutospores from Carex stipata Muhl. and C. aquatilis Wahl. sown on Urtica gracilis Ait.

8. Puccinia fraxinata (Schw) Arth.-Teleutospores from Spartina cynosuroides Willd. sown on Fraxinus lanceolata Borck.

9. Puccinia amphigena Diet. - Teleutospores from $\mathrm{Ca}$ lamovilfa longifolia (Hook.) Hack. sown on Smilax hispida Muhl.

io. Puccinia verbenicola (E. \& K.) Arth. - Teleutospores from Sporobolus longifolius (Torr.) Wood, sown on Verbena urticaefolia L.

i i. Puccinia pustulata (Curt.) Arth. - Teleutospores from Andropogon furcatus Muhl. sown on Comandra umbellata (L.) Nutt.

i2. Puccinia Pammeliz (Trel.) Arth. - Teleutospores from Panicum virgatum L. sown on Euphorbia corollata L.

I3. Puccinia subnitens Diet. - Teleutospores from Distichlis spicata (L.) Greene, sown on Erysimum asperum DC., Sophia incisa (Eng.) Gr., Lepidium Virginicum L. and Bursa Bursa-pastoris (L.) Britt.

14. Pliccinin poclliformis (Jacq.) Wettst. - Teleuto-spores from Agrostis alba L. sown on Berberis vulgaris L. 
15. Puccinia Sorghi Schw--Teleutospores from Zea Mays L. sown on Oxalis cymosa Small.; aecidospores from Oxalis cymosa, sown on Zea Mays; and uredospores from Zea Mays sown on same host.

i6. Puccinia Polygoni-Amphibir Pers. - Teleutospores from Polygonum emersum (Michx.) Britt. sown on Geranium maculatum L.

i7. Puccinia Helianthi Schw. - Teleutospores from Helianthus grosse-serratus Mart. sown on $H$. grosse-serratus Mart. and $H$. annuus L.

i8. Puccinia lateripes B. \& Br. - Teleutospores from Ruellia ciliosa Pursh, sown on $R$. ciliosa Pursh and $R$. strepens $\mathrm{L}$.

19. Puccinia Pruni-spinosae Pers. - Aecidiospores from Hepatica acutiloba D C. sown on Prunus serotina Ehrh.

20. Puccinia Xanthil Schw. - Resting teleutospores from Xanthium Canadense Mill. sown on same host.

\section{B. Species reported now for the first time.}

I. Puccinia Silphir Schw. - Resting teleutospores from Silphium integrifolium Michx. sown on same host.

2. Puccinia Grindeliae Pk. - Resting teleutospores from Gutierrezia Sarothrae (Pursh) B. \& R. sown on same host.

3. Puccinia Solidaginis $\mathrm{Pk}$. - Resting teleutospores from Solidago trinervata Greene, sown on S. Canadensis L.

4. Puccinia transformans E. \& E. - Resting teleutospores from Stenolobium Stans (L.) Don. sown on same host.

5. Puccinia Kuhniae Schw. - Teleutospores from Kuhnia eupatorioides L. sown on same host.

6. Puccinia canaliculata (Schw.) Lagerh. - Aecidiospores from Xanthium Canadense Mill. sown on Cyperus esculentis L.

7. Puccinia Eleocharidis Arth. - Teleutospores from Eleocharis palustris (L.) R. \& S. sown on Eupatorium perfoliatum L.

8. Puccinia substerilis E. \& E.-Amphispores from Stipa viridula Trin. sown on same host.

9. Puccinia Seymouriana Arth. - Teleutospores from Spartina cynosuroides Willd. sown on Cephalanthus occidentalis $\mathrm{L}$.

IO. UROMYCES acuminatus Arth. - Teleutospores from Spartina cynosuroides Willd. sown on Steironema ciliatum (L.) Raf.

Purdue University, Lafayette, Ind. 



\title{
(4)
}

Reprinted from the Journal of Mycology, $13: 189-205$, September, 1907.

\section{CULTURES OF UREDINEAE IN $1906 .^{1}$}

\author{
BY J. C. ARTHUR.
}

The present article forms the seventh of a series of reports ${ }^{2}$ by the author upon the culture of plant rusts, covering the years from 1899 to the close of 1906 . As in previous years the grass and sedge rusts have constituted a large part of the list of species under trial. This is partly due to the economic and scientific interest connected with them, but even more, possibly, to the greater ease with which wintered-over and viable spores may be secured for cultural study. Among the species whose life-

${ }^{1}$ Read before the Botanical Society of America at the New York meeting, December 31, 1906.

${ }_{2}$ See Bot. Gaz. $29: 268-276,35: 10-23$; Jour. Myc. 8:51-56, I0:8-21, $I I: 50-67$ and $I 2: 11-27$. 
cycle has now been worked out for the first time, the one having the greatest economic inport does not belong to the grass or sedge forms, but inhabits flax. The discovery of the full developmental history of this serious menace to successful flax growing, brought about by the cooperation of Professor Henry L. Bolley of North Dakota, widely known for his interest and scientific studies in promoting the flax industry, has been a matter of much satisfaction. It greatly clarifies the problem of controlling the flax rust in the interest of the cultivator.

The work of testing the viability of spores, making the sowings, and recorded data, required, as in previous years, the undivided attention of a person to whom the whole work could be intrusted. The expense of such an assistant was this year met by a grant from the Botanical Society of America. It was the second time the Society has given material aid to this series of investigations.

Through the kindness of Professor R. A. Harper, I was so fortunate as to enlist the interest of Dr. E. W. Olive, lecturer at the University of Wisconsin, who consented to supervise the season's work. The forethought and constant watchfulness, the enthusiastic application, and especially the maturity of judgment and breadth of knowledge brought to bea* on the work by Dr. Olive materially increased the completen' i of the results. As in former years correspondents $h$ of the material used in the trials, partly upor and partly in response to suggestion, for al: provided much ir own initiative, which I am under heavy obligation. Teliosporic material wá ent by Messrs. A. D. Selby, Wooster, Ohio; H. H. Whetzel, thaca, N. Y.; Chas. E. Fairman, Lyndonville, N. Y.; W. A. Kellerman, Columbus, Ohio; H. L. Shantz, Columbia, Mo.; J. J. Davis, Racine, Wis.; John L. Sheldon, Morgantown, W. Va.; H. L. Bolley, Agricultural College, N. D.; E. Bartholomew, Stockton, Kans.; Geo. E. Morris, Waltham, Mass.; Guy W. Wilson, Lafayette, Ind.; E. Bethel, Denver, Colo.; and especially by Rev. J. M. Bates, Red Cloud, Neb. Aeciosporic material was sent by Messrs. Herman von Schrenk, St. Louis, Mo.; H. H. Whetzel, Ithaca, N. Y.; C. L. Shear, Tacoma Park, D. C.; D. Reddick, Ithaca, N. Y.; and P. H. Rolfs, Lake City, Fla., all the collections being either Caeoma or Peridermium on species of Pinus. Host plants are often required for the work, which do not grow in this vicinity, and can not be purchased from dealers, and for a number of such plants in good growing condition I am indebted to Messrs. William Trelease of the Missouri Botanical Garden, St. Louis, Mo.; John L. Sheldon, Morgantown, W. Va.; P. B. Kennedy, Reno, Nev.; and J. J. Davis, Racine, Wis.

During the present season 94 collections of material with resting spores and I 5 collections with active spores were employed, from which 293 drop cultures and 6 Petri dish cultures 
were made to test the germinating condition of the spores. Out of the 94 collections with resting spores 46 could not be made to germinate, although no reason could be assigned why they should not. This gave 48 collections of available material belonging to 30 species of rusts, exclusive of the aecial pine rusts, and from these 223 sowings were made. Beside these 53 sowings were made with Caeoma and Peridermium spores from pine, all without infection, 27 sowings with teliospores of Gymnosporangium, and 23 sowings with various aeciospores. Altogether 326 sowings were made, and for this purpose 134 species of hosts were required, which were grown temporarily in the greenhouse, where practically all the work was done. The results of this work are given in the following paragraphs, and are divided into negative results, positive results with species whose life histories have already been previously determined, and positive results with species whose life histories have not before been fully known.

Of the trials giving negative results the following may be recorded to serve for reference in further studies.

1. Puccinia on Carex Pennsylvanica Lam., collected near Lafayette, Ind., was sown on Trillium recurvatum, Napaea dioica, Anemonella thalictroides, Isopyrum biternatum, Anemone virginiana, Actaea alba, Viola cucullata, Dirca palustris, Polemonium reptans, Ambrosia trifida, Rudbeckia laciniata, and Lactuca canadensis, with no infection. Similar material in former seasons has been tried on eighteen other species of hosts with negative results. ${ }^{3}$

2. Puccinia on Carex gravida Bailey, sent by Rev. J. M. Bates from Red Cloud, Neb., was sown on Actaea rubra, Thalictrum dioicum, Isopyrum biternatum, Apios Apios, Falcata comosa, Psoralea Onobrychis, Cassia Chamaecrista, Polygala Senega, Aesculus glabra, Ceanothus americanus, Smilax herbacea, Viola cucullata, Napaea dioica, Callirrhoe involucrata, Althaea rosea, Hibiscus Moscheutos, Macrocalyx Nyctelea, Polemonium reptans, Myosotis palustris, Phlox divaricata, Phlox subulata, Triosteum perfoliatum, Boltonia asteroides, Laciniaria pycnostachya, Rudbeckia laciniata, Senecio obovatus, and Cacalia reniformis, with no infection. Similar material from the same source has been sown in previous years upon eleven other species of hosts with negative results. ${ }^{4}$

3. Puccinia on Polygonum scandens L., obtained in the vicinity of Lafayette, Ind., was sown five times on Geranium maculatum, twice on G. Robertianum, twice on G. pusillum, and

${ }^{8}$ See Jour. Myc. $I 0: 10$. 1904; II:51. 1905; and $I 2: 12.1906$.

- See Jour. Myc. $I 0: 10.1904 ;$ and $I I: 52$. 1905. 
twice on Thalictrum dioicum. These sowings were made under seemingly favorable conditions and yet no infection resulted. In 1903 Dr. W. Tranzschel of St. Petersburg established the connection between Puccinia Polygoni-amphibii Pers. on Polygonum amphibium and the aecia on Geranium palustre and $G$. pratense, and a year later the writer corroborated the discovery with corresponding American species of hosts. In 1904 Dr. Tranzschel showed that the rust on climbing species of Polygonum, often included with the preceding, is distinct, either as a true species or a biological species, for it produces its aecia on Geranium pusillum. To see if this also could be substantiated with American material the above sowings were made with seemingly excellent teliosporic material, but the negative results leave the matter an open question. The only other native Geranium on which this form might be expected to grow readily is G. carolinianum, which was unfortunately not at hand for the test.

4. Puccinia on Muhlenbergia diffusa Schreb., sent by Rev. J. M. Bates from Red Cloud, Neb., was sown on Trillium recurvatum, Actaea alba, Anemonella thalictroides, Isopyrum biternatum, Caulophyllum thalictroides, Apios Apios, Viola pubescens, Dirca palustris, Althaea rosea, Callirrhoe involucrata, Napaea dioica, Hibiscus Moscheutos, Marcrocalyx Nyctelea, Polemonium reptans, Ambrosia trifida, and Lactuca canadensis, with no infection. This taken with previous trials shows that the rusts on different species of Muhlenbergia are in all probability biologically complex.

5. Puccinia Schedonnardi K. \& S., sent by Rev. J. M. Bates from Red Cloud, Neb., was sown on Callirrhoe involucrata, Althaea rosea, and Ceanothus americanus, with no infection. Like material from the same source was sown in 1902 on eight other species of hosts with negative results. ${ }^{5}$ The small sori and fine leaves of the grass make the manipulation of material of this species somewhat uncertain.

6. Puccinia emaculata Schw. on Panicum capillare, obtained in the vicinity of Lafayette, Ind., where it is very common, was sown on Polygala Senega and Napaea dioica. This rust was sown in previous seasons on eighteen other species of hosts. ${ }^{6}$

7. Uromyces on Juncus effusus L., sent by Dr. Charles E. Fairman from Ridgeway, N. Y., was sown on Polemonium reptans, Houstonia purpurea, Ambrosia trifida, Rudbeckia laciniata, Polymnia canadensis, Parthenium integrifolium, Silphium integrifolium, S. perfoliatum S. terebinthinaceum, and Senecio obovatus,

See Bot. Gaz. $35: 11.1903$

- See Bot. Gaz. 35:12. 1903; Jour. Myc. 8:52. 1902; Io:10. 1904; and $12: 12.1906$. 
with no infection. What was doubtless the same rust, and also from western New York, was sown in 1905 on two other species of hosts with negative results. ${ }^{\text {? }}$

This rust has heretofore been considered to belong to Uromyces Junci (Desm.) Tul., but recent study has shown that it is morphologically quite distinct from that species, especially as it has urediniospores that are echinulate and four-pored, instead of verrucose and two-pored, as in the European species, which by the way apparently does not occur in the United States east of Nebraska and Kansas. It was described by Schweinitz (Trans. Am. Phil. Soc. 4:295. I832.) as a new species under the name Puccinia Junci. As that specific name is not now available, I suggest that the species be called Uromyces effusus, in allusion to the copious distribution of the sori over the surface of the host, and would characterize it as follows:

\section{Uromyces effusus sp. nov.}

$\mathrm{O}$ and I. Pycnia and aecia unknown.

II. Uredinia amphigenous, scattered, oblong or linear, $0.1-0.3 \mathrm{~mm}$. wide by $0.3-1.5 \mathrm{~mm}$. long, tardily naked, dark cinnamon-brown, ruptured epidermis very conspicuous; urediniospores broadly ellipsoid or oval, 14-19 by $18-26 \mu$, wall light yellow about $1.5 \mu$ thick, rather sparingly and bluntly echinulate, pores 4, equatorial.

III. Telia amphigenous, numerous, scattered, oblong or linear, 0.2$0.5 \mathrm{~mm}$. wide by $0.3-2 \mathrm{~mm}$. or more long, rarely confluent, finally naked, ruptured epidermis very conspicuous; teliospores obovate or broadly oval, 13-19 by $24-33 \mu$, obtuse or rarely acute at apex, usually narrowed below; wall chestnut-brown, 1.5-2 $\mu$ thick, much thicker above, 6-10 $\mu$, smooth; pedicel tinted, about as long as the spore.

On Juncus effusus L. Type collected by L. von Schweinitz at Bethlehem, $\mathrm{Pa}$. Collections in the writer's herbarium from Ohio, New York, West Virginia, and Maryland, and in the herbarium of the New York Botanical Garden from New Jersey, Massachusetts and South Carolina. It is also found in the following exsiccati: Ellis, N. Am. Fungi. 238; Ellis \& Ev., Fungi Columb. 339; Ravenel, Fungi Am. 51; Shear, N. Y. Fungi 76 ; Kellerm., Ohio Fungi 38.

8. URomyces Eleocharidis Arth. on Eleocharis palustris (L.) R. \& S., sent by Mr. E. Bartholomew from Stockton, Kan., was sown on Callirrhoe involucrata, Napaea dioica, Cassia Chamaecrista, Myosotis palustris, and Silphium perfoliatum, with no infection.

9. Uromyces acuminatus Arth. on Spartina cynosuroides Willd., obtained at Fair Oaks, Ind. by Mr. F. D. Kern, was sown four times on Steironema ciliatum, twice on S. lanceolatum, twice on Lysimachia quadrifolia L., and once each on L. tcrrestris, Polygala Senega, Napaea dioica and Houstonia purpurea, with no infection. As teliosporic material of this rust, obtained from $\mathrm{Ne}$ braska, was sown on Steironema ciliatum with success in $1905{ }^{8}$

${ }^{7}$ See Jour. Myc. I2:13. 1906.

${ }^{3}$ See Jour. Myc. I2:24. 1906. 
it would seem that what now passes under one name is either a segregate, or a series of biological species, and that the Uromyces on Spartina in Indiana differs in some way from that in Nebraska.

The following species of rusts were successfully grown, and the data supplement that obtained from previous cultures of this series, or that recorded by other American or European investigators.

I. Melampsora Bigelowi Thuem. - Teliosporic material obtained near Lafayette, Ind., on Salix sp., was sown April 25 on Larix decidua, pycnia appearing in abundance May 2, and fully grown aecia about May $12 .{ }^{\circ}$

2. Cronartium Quercus (Brond.) Schroet. - Work with this species was suggested by Dr. C. L. Shear, who also provided freshly gathered aecia on Pinus virginiana Mill., sending these a number of times in varying quantity. Dr. Shear made a number of cultures in the open in the spring of 1905, and presented a paper embodying his observations and conclusions ${ }^{10}$ at the New Orleans meeting of the American Mycological Society, but which did not appear in print until June, 1906, after all data to be presented here were secured.

Aeciospores from material provided by Dr. Shear was sown May 12 in the greenhouse on three plants of Quercus alba and two plants of $Q$. velutina. On May I9 another sowing was made on two other plants of $Q$. velutina. This work coming late in the season did not receive daily examination, but on June I all the plants of $Q$. velutina showed uredinia, and one of them also had developed telia. By June 25 the remaining four plants had produced telia. The plants of $Q$. alba remained free from infection.

The aecia used for these cultures were the typical form of Peridermium Cerebrum Peck. There seems no reason to doubt the identity of the American, European and Japanese fungus, which has passed under a number of names, but a discussion of the literature and facts will not be taken up in this place.

3. Puccinia Opizi Bubák- - Aecia on various wild species of Lactuca, and even on the garden $L$. sativa, are common in the extended region of the upper Mississippi valley. They were described by Burrill (Bull. Ill. Lab. Nat. Hist. 2:232. 1885), but the name Aecidium compositarum Lactucae Burr. was first published three years later (Saccardo, Syll. fung. 7: 799. I888). This form has often appeared in considerable abundance within

- For previous cultures see Jour. Myc. II:60. 1905.

*(10 Jour. Myc. 12:89-92. 1906. 
a hundred feet of my laboratory door, and much attention has been bestowed upon it. The first clue to its connection was found on the last day of April of this year, when in company with Mr. F. D. Kern, the writer detected at Fair Oaks, Ind., a hundred miles north of this place, in two well separated spots, some plants of Lactuca canadensis thickly covered with aecia, and intermixed with the affected leaves some leaves of a small, narrow leaved Carex, bearing teliospores of the previous year's growth. No evidence of fruiting could be found on the Carex, and roots brought back and grown in pots have shown no signs of fruit, so that the Carex has not been specifically determined. Teliosporic material was obtained from both localities, and May 2 one was sown on Lactuca canadensis and Onagra biennis, the other on $L$. virosa and two plants of $L$. canadensis. Onagra showed no infection, but all plants of Lactuca gave rise to pycnia May 9, and aecia May 15, in great abundance. Another sowing was made May I4 on L. sativa, which gave pycnia May I4, and aecia May 28, with ample development.

This rust is taken to be the same as the one which Dr. Fr. Bubák studied in Bohemia by means of cultures, and which he has very fully rescribed. ${ }^{11}$ No Bohemian collections, however, are at hand with which to make comparison, but two European collections of accia (Sydow, Uredineen 334 and Iroo) show essential morphological agreement with American aecia on Lactuca. Dr. Bubál: (1. c.) has stated that to him the American and European coilections appear distinct, but without saying wherein the difference may lie. To me the differences appear to be habital. On thin leaved hosts both pycnia and aecia are in more open and indefinite groups. On hosts from the western prairies, which have firm and strongly developed leaves the groups of aecia are usually compact and circumscribed, and surround the often amphigenous pycnia. The European aecia belonging to the species are known under the name Accidium lactucinum Lagherh. \& Lindr.

4. Puccinia Sambuci (Schw.) Arth. - Teliosporic material on Carex Frankii Kunth, brought from Frankfort, Ind., by Mr. F. D. Kern, was sown May ro on Sambucus canadensis, giving numerous pycnia May I6, and abundance of aecia May 26. This adds another host to this common species, those already known being Carex trichocarpa, C. lurida, and C. lupulina. ${ }^{12}$

5. Puccinia Peckir (DeT.) Kellerm.-Teliosporic material on Carex trichocarpa Muhl., brought from Fair Oaks, Ind., was sown on Onagra biennis May 4, and gave rise to pycnia May I4, and to aecia May I7, both in abundance. Another collection on C. lanuginosa Michx., sent by Rev. J. M. Bates

${ }^{11}$ Centr. Bakt. 9 :924. 1902.

${ }^{12}$ See Bot. Gaz. 35:14. 1903; Jour. Myc. 8:55. 1902; I2:14. 1906. 
from Wymore, Neb., was sown on Onagra biennis May I9, giving rise to pycnia May 26, and aecia June 2, both in abundance. ${ }^{13}$

6. Puccinia albiperidia Arth. - This rust on three species of hosts was obtained in different localities near Lafayette, Ind., and sown with the following results:

From Carex squarrosa L., sown in greenhouse April 16 on Ribes rotundifolium; April 21, pycnia; April 30, aecia.

From C. squarrosa L., sown in garden April 21 on $R$. gracile; April 25, -pycnia; May 13, aecia.

From C. squarrosa L., sown in greenhouse April 16 on $R$. rubrum; no infection.

From C. tetanica Schk., sown in greenhouse April 20 on $R$. Cynosbati; April 27, pycnia; May 9, aecia.

From C. crinita Lam., sown on $R$. Cynosbati in greenhouse April 26, then plant transferred to garden; May 4, pycnia; May 17, aecia.

These results add one more telial host to those previously used for cultures. ${ }^{14}$ They also have given an opportunity for a study of the differences between the pale aecia obtained by cultures and the highly colored aecia usually observed in the field. The aecia grown wholly in the greenhouse were pale, as in previous years; those on the plant which had the pot plunged into the garden soil after the fungus became established, were much more colored; and those raised from sowings made in the garden were highly colored and presented essentially the same appearance as others that came upon some nearby bushes of Ribes from natural infection. The result of observations during the last six years, coupled with the cultures of this year, make the conclusion almost inevitable that shade, moist air, and slow growth, tend to make the aecia smaller, with less coloring matter in the peridial cells and surrounding mycelium, and also tend to produce less hypertrophy of the tissues of the host, and that this accounts for the differences observed between aecia grown in cultures and those very common on Ribes Cynosbati, $R$. rotundifolium, $R$. gracile, and similar species of gooseberries throughout the eastern United States. All collections of this sort, therefore, may be called Puccinia albiperidia, but whether this is a distinct species from the very similar rust of Europe, Puccinia Grossulariae (Schum.) Lagerh., or one of the several biological species established by Klebahn, still remains an open question.

7. Puccinia angustata Peck. - Teliosporic material on Scirpus atrovirens Muhl., from the vicinity of Lafayette, Ind., was sown April 28, on Dirca palustris, with no infection. On

${ }^{13}$ For previous cultures see Bot. Gaz. $35: 13$. 1903; Jour. Myc. 8:55. 1902 ; II:58. 1905; and $I 2: 15.1906$.

${ }_{14}$ For previous cultures see Jour. Myc. 8:53. 1902; I0:11. 1904; $I I: 58.1905$; and $I 2: 14.1906$. 
May 4 it was sown on Lycopus Americanus, giving rise May I4 to numerous pycnia, and May 18 to aecia in abundance. ${ }^{15}$

8. Puccinia Eleocharidis Arth. - Teliosporic material on Eleocharis palustris (L.) R. \& S., sent by Mr. E. Bartholomew from Stockton, Kans., was sown May 7 on Eupatorium perfoliatum, giving rise to pycnia May I4, and to aecia May 22. Similar material on same species of host from near Lafayette, Ind., was sown June I on E. perfoliatum, giving rise to pycnia June 8, and to aecia June 20. It was also sown on Napaea dioica, with no infection. ${ }^{16}$

9. Puccinia Andropogonis Schw. - Teliosporic material on Andropogon scoparius Michx., sent by Rev. J. M. Bates from Sargent, Neb., was sown April 24 on Pcntstemon hirsutus, giving rise to pycnia April 30, and to aecia May 10, both in abundance. ${ }^{17}$

io. Puccinia tomipara Trel. - Teliosporic material on Bromus purgans L., from Lafayette, Ind., was sown May I9 on Clematis virginiana, giving rise to pycnia May 26, and to aecia June 8 , both in abundance. ${ }^{13}$

iI. Puccinia subnitens Diet. - Teliosporic material on Distichlis spicata (L.) Greene, sent by Rev. J. M. Bates from Red Cloud, Neb., was sown April 5 on Chenopodium album, Bursa Bursa-pastoris, and Sarcobatus vermiculatus, giving a weak infection only on the Chenopodium. As the Sarcobatus plant soon died, another sowing was made May 5 on two other plants of Sarcobatus, but with no infection. It was sown again May ro, and May 19, on Sarcobatus, still with no infection. Still a fifth sowing was made May 29 on two plants of Sarcobatus, and one of Chenopodium album, with a weak infection of the latter, and with apparently a few pycnia showing on one leaf of Sarcobatus. The plants of Sarcobatus were sent.by Dr. P. B. Kennedy from Reno, Nev., and had not become established when the sowings were made. They were obtained where Distichlis spicata grew intermixed, well covered with Puccinia subnitens, and the Sarcobatus was well besprinkled with aecia, not distinguishable from those now known to belong to this grass rust. ${ }^{19}$ The particular object in view was to determine experimentally if Puccinia subnitens will grow on Sarcobatus. The single seeming infection is doubtful, as it may have come from spores transported with the plants. The question remains an open one,

${ }^{13}$ For previous cultures see Bot. Gaz. 29:273. 1900; and Jour. Myc. $8: 53.1902$.

${ }^{10}$ For previous cultures see Jour. Myc. r2:23. 1906.

${ }^{17}$ For previous cultures see Bot. Gaz. 29:272. 1900; Jour. Myc. $9: 10$. 1903; and $10: 11.1904$.

${ }^{18}$ For previous cultures see Jour. Myc. $I 1: 62.1905$.

${ }^{10}$ For previous cultures see Bot. Gaz. 35: 19. 1903; Jour. Myc.

$I I: 54.1905 ; 12: 16.1906$. 
although I venture the opinion that if the teliosporic material had come from Nevada, instead of Nebraska, the sowings would have been successful.

12. Puccinia poculiformis (Jacq.) Wettst. - Teliosporic material on Agrostis alba L., brought from Fair Oaks, Ind., was sown May 2 on two plants of Berberis vulgaris, both showing abundant pycnia May 9, and aecia May I8.

Aeciospores from these cultures were sown May $3 \mathrm{I}$ on Avena sativa, Hordeum vulgare (Great Beardless), and Triticum vulgare (Jones' Silver Sheaf), without infection in the first case, and with sparing infection in the other two cases, the former showing uredinia June 12, and the latter somewhat later.

Teliosporic material on Elymus canadensis L., sent from Racine, Wis., by Dr. J. J. Davis, was sown May 2 on Berberis vulgaris, showing pycnia May 9, and aecia May 18. Aecia from this culture were sown May 3I on Triticum vulgare (Jones' Silver Sheaf), and Secale cereale (Mammoth Winter Rye), with no infection. ${ }^{20}$

13. Puccinia transformans Ellis \& Ev. - Teliosporic material from a greenhouse plant of Stenolobium Stans, which had been infected a year previously, was sown May 7 on two healthy plants of the same species, and gave rise to pycnia May 22, and to telia May 30. A sowing on two other plants was made May Io, showing pycnia May 26, and telia May 31. ${ }^{21}$

I4. Puccinia Xanthil Schw.- Teliosporic material on Xanthium sp., obtained in the vicinity of Lafayette, Ind., about the middle of April, was sown on Xanthium seedlings April 20, and gave rise to translucent papillae simulating pycnia April 26, and open telia May 3. Another sowing May I gave pale papillae about May 18, and open telia about May $26 .{ }^{22}$

I5. Puccinia Silphir Schw. - Teliosporic material on Silphium integrifolium Michx., obtained the last of March near Lafayette, Ind., was sown April 26 on Silphium perfoliatum, giving rise to pale papiilae May I, and open telia May 4. Another sowing was made on $S$. terebinthinaceum May I, giving rise to pale papillae May 8, and open telia May I4. Similar material from another locality was sown May 3 on S. integrifolium, S. perfoliatum and $S$. terebinthinaceum, giving infection in usual way in each instance but exact data not taken. ${ }^{23}$. It was observed that the infection on S. integrifolium was more rapid in its growth and more abundant than on the other hosts. In the report of last

${ }^{20}$ For previous cultures see Jour. Myc. 8:53. 1902; II:57. 1905; I2:17. 1906.

${ }^{\text {i1 }}$ For previous cultures see Jour. Myc. I2:22. 1906.

$\approx$ For previous cultures see Jour. Myc. I2:20. 1906.

${ }^{23}$ For previous cultures see Jour. Myc. $12: 21.1906$. 
year's cultures the opinion was expressed that this rust may be composed of biological races, but the present work shows that adaptation to the hosts is not so close but that under specially favorable conditions the rust may be transferred from one host to another.

i6. Puccinia Pruni-spinosae Pers.-Aecia on Hepatica acutiloba DC., from near Lafayette, Ind., were sown April 28 on Prunus serotina and Amygdalus Persica, giving rise May $2 \mathrm{I}$ to uredinia on the former host, but with no infection on the latter host. Like material was sown May 2 on Prunus serotina and $P$. pumila, giving rise to the uredinia in both instances May 21 . These results abundantly confirm, and somewhat extend, the work of last year. ${ }^{24}$

17. Uromyces Scirpi (Cast.) Burr.-Teliosporic material on Scirpus Aluviatilis (Torr.) A. Gray, sent by Rev. J. M. Bates from Walbach, Neb., was sown May 22 on Cicuta maculata, giving abundance of pycnia May 3I, and of aecia June 8. A sowing made June I on Pastinaca sativa, the plants being especially thrifty, gave no infection. On June 5 another sowing was made on Oxypolis rigidus and Cicuta maculata, with no infection on the former, but with fine showing of pycnia on the latter June 12, and of aecia June 22.

There is apparently no morphological difference between the American rust and the corresponding European one, and the hosts are also much alike. Sixteen years ago Dr. P. Dietel showed by cultures ${ }^{25}$ that in central Germany aecia are produced on Sium latifolium, which in habit and structure is much like Cicuta maculata. He also found that, most curiously, aecia could be grown from the same material on Hippurus vulgaris, which belongs to another family of plants, showing that, in all probability, the species is not closely circumscribed.

Cultures made by Dr. Fr. Bubák in Igor from Bohemian material brought to light a biological form which only infected Berula angustifolia. ${ }^{28}$

In 1902 Dr. H. Klebahn attempted to repeat Dietel's cultures, and found that teliosporic material from the same immediate region, the exact locality having been changed and the rust destroyed, gave abundant aecia on Pastinaca sativa, but only slightly infected Hippurus vrulgaris, and infected Sium latifolium and Glaux martima not at all. ${ }^{27}$ The year following he carried out more extensive cultures. Teliosporic material raised from aeciospores on Pastinaca sativa, infected both Pastinaca and Berula angustifolia. Teliosporic material from central Germany

« See Jour. Myc. I2:19. 1906.

${ }^{25}$ Hedwigia $29: 149.1890$.

* Centr. Bakt. $9^{2}: 926.1902$.

n Jahrb. Hamb. Wiss. Anst. 20 :33. 1903. 
infected both these hosts. Similar material from northern Germany infected only Berula. In IgO4 aecia were raised in a similar way on Oenanthe aquatica..$^{28}$

One of the earliest cultures with this pleophagic species was made by Mr. C. B. Plowright with English material, raising aecia on Glaux maritima, which belongs to the Primulaceae. ${ }^{29}$

A careful microscopic study of all these forms shows close agreemenit in morphological characters, and altogether there appears to be no reason to treat these cultural forms other than biological races of a single species. Scirpus fluviatilis is the American representative of the European S. maritimus, and by many authors is given the latter name. The writer has examined American collections that appear to belong to this species, as follows: on S. fluviatilis from Iowa, Illinois, Kansas, Nebraska, South Dakota, Ohio, and Wisconsin; on Cicuta maculata from Illinois, Iowa, and Colorado; on Oenanthe californica from central California, Sium cicutacfolium from Wisconsin, and on Glau.x maritima from Montana and Wyoming.

i8. Gymnosporangium Juniperi-virginianae Schw.Galls from a tree of Juniperus virginiana near the laboratory, brought in by Mr. F. D. Kern, were used for sowing May I on Malus coronaria, Sorbus americana, and Crataegus Pringlei. Only the first gave infection, which showed abundant pycnia on May 14, but failed to develop aecia on account of injuries. ${ }^{25}$

I9. Gymnosporangium globosum Farl.-Galls from a tree of Juniperus virginiana, found in the vicinity of Lafayette, Ind., were brought in by Mr. Guy W. Wilson, and used for making three sowings on Crataegus Pringlei, and one each on Malus coronaria and Amelanchier sp. All sowings on Crataegus gave abundance of pycnia, and one plant finally produced well formed aecia, the other plants not growing well. No infection was obtained on the other two hosts.

Similar material was also received from Dr. John A. Sheldon, of Morgantown, W: Va., and sown May I9 on Crataegus Pringlei, Malus coronaria, and Sorbus americana, all giving rise to an abundance of pycnia. As none of the plants grew well, only the sowing on Sorbus formed aecia, these finally reaching maturity and showing the characteristic structure of the species.

These results are parallel with, and confirm the work by Dr. Roland Thaxter, done some years ago. ${ }^{20}$

${ }^{28}$ Ztschr. Pf.-Kr. I5:74. 1905.

${ }^{2}$ Gard. Chron. III. $7: 682.1890$.

${ }^{25}$ For previous cultures see Jour. Myc, I2:13. 1906.

${ }^{20}$ Proc. Amer. Acad. Sci. 22 :263. 1887; Bot. Gaz. I4:167. 1889. 
The following three species have never before been tested by means of cultures, so far as the writer knows. Although few in number, they make an important addition to our knowledge of life histories:

I. Melampsora Lini (Link) Desmaz.-For a number of years attempts have been made to obtain cultures of this cosmopolitan rust, and learn its full cycle of development. Many collections from different parts of the country, gathered at different times from November to April, have been tested, but with uniform failure to secure germination of the teliospores. The most numerous and promising collections were sent by Professor $\mathrm{H}$. L. Bolley, of North Dakota, but equally in vain until one made the last day of April on cultivated flax, dug from under a snow bank, was received. This showed strong germination of the teliospores, and on May 4 was sown on Linum Lercisii, Larix laricina, and the day following on Tsuga canadensis, and Arisaema triphyllum. No clues were available, but judging from the willow, poplar, and some other species of the same genus, it was assumed that it might be heteroecious. Nevertheless, on May I6 pycnia began to appear on the flax, and on May 2I aecia. The next sowing was made May 18 on Linum usitatissimum, plants of which had not before been available, giving rise to pycnia May 26, and aecia May 30. Another equally successful sowing on the same host was made May 29, but exact record for the appearance of the sori was not kept.

The pycnia are small, pale, and inconspicuous, although numerous. They are globoid, subepidermal, and without ostiolar filaments. The aecia are of the caeoma form, that is, are without peridia. They are also rather pale, and not as prominent as the uredinia, for which, however, they might easily be mistaken. So far as I can learn they have never been collected, although probably common throughout the world. This may be due to their being inconspicuous, and quite as much to the earliness of their appearance.

The economic bearing of the discovery is to some extent obvious. Knowing the autoecious nature of the rust makes the destruction of old flax straw in flax growing regions a matter of moment, in order to lessen and retard the appearance of the rust in growing fields of flax. Upon reporting the first success to Professor Bolley he replied under date of May 23, 1906: "I am very much pleased to receive your letter, for with the information I am able to determine the source of a rust epidemic that we had in our flax breeding plots last year. I now find everywhere in the flax stubble plenty of volunteer flax with almost every plant more or less infected with spermogonia and aecidia." It will now be possible to intelligently devise methods. for the practical control of flax rust. 
2. UROMyces on JUNCUS TENUIS. - This rust, which has generally passed under the name of Uromyces Junci, is very common in the United States east of the Rocky Mountains from Canada to the Gulf of Mexico. It is often highly parasitized, so that the sori contain few or no well grown teliospores. A number of attempts to bring the rust under culture have failed because the teliospores could not be made to germinate. In 1902 a sowing was made on Iris virsicolor without success.

Unparasitized material on Juncus tenuis Willd. was found near Lafayette, Ind., April 3, that proved to be viable, and was sown April 20 on Lactuca canadensis, L. virosa, Senecio obovatus, Rudbeckia laciniata, Ambrosia trifida, A. artemisiaefolia, and Silphium perfoliatum. Much to our delight pycnia were observed on the last host April 30, and were followed by a great abundance of aecia May 7 . Another sowing was made May 4 on $S$. perfoliatum and $S$. terebinthinaceum, and the next day on Parthenium integrifolium. Only the first was infected, showing pycnia May I7, and May 3I. The plant of S. terebinthinaceum was weak and did not grow well. Later sowings May 9 on Polymnia canadensis, and June 5 on Pathenium integrifolium and Silphium terebinthinaceum, gave no infection.

Another collection of teliospores on Juncus tenuis was sent by Dr. John L. Sheldon from Morgantown, W. Va., which was found close to Houstonia caerulea bearing aecia. This material was sown May 19 on Houstonia caerulea, $H$. purpurea and Silphium perfoliatum. No infection occurred on the Houstonias, but pycnia appeared on the Silphium May 29, and aecia June 4, both abundant and well formed.

Since obtaining the unequivocal cultural results, a morphological study has been made of the rust, which clearly demonstrates that it is specifically distinct from Uromyces Junci (Desm.) Tul. As it appears never to have been recognized as an autonomous species, the following name and description are submitted:

Uromyces Silphii (Syd.) nom. nov. (Accidium compositarium Silphii Burr. Saccardo, Syll. Fung. 7:798. 1888; Aecidium Silphii Sydow, Uredineen 1546 .)

O. Pycnia chiefly epiphyilous, in small groups, golden brown, subglobose or ellipsoid, subepidermal, $80-100 \mu$ broad by $80-110 \mu$ high; ostiolar filaments up to $65 \mu$ long.

I. Aecia amphigenous, in groups $4-10 \mathrm{~mm}$. across, crowded about the pycnia on discolored spots, deep-seated, short, $0.2-0.4 \mathrm{~mm}$. in diameter; peridium colorless, margin recurved, lacerate, peridial cells rhombic, $20-28 \mu$ across, outer wall thick, $6-8 \mu$, transversely striate, inner wall thinner, 4-6 $\mu$, moderately verrucose; aeciospores angularly globoid, small, 13-18 $\mu$ in diameter, wall colorless, thin, about $1 \mu$, minutely verrucose.

On Silphium integrifolium Michx., Illinois (type, McLean County, May 3, 1881 or 1882, A. B. Seymour 4852, recorded in Burrill's Parasitic Fungi of Illinois, page 231), Wisconsin; S. terebinthinaceum Jacq., Illi- 
nois, Wisconsin, Missouri; S. perfoliatum L., Indiana, Iowa, Wisconsin; S. laciniatum L., Illinois, Iowa, Kansas.

II. Uredinia amphigenous, scattered, roundish or somewhat elongated, small, $0.2-0.3 \mathrm{~mm}$. wide, by $0.3-0.5 \mathrm{~mm}$. long, tardily naked, dark cinnamon-brown, ruptured epidermis not conspicuous; urediniospores $^{-}$ broadly ellipsoid or sometimes obovate, $13-19$ by $15-23 \mu$, wall golden yellow, about $1.5 \mu$ thick, sparsely and bluntly echinulate, pores 5 or 6 , scattered.

III. Telia amphigenous, scattered, roundish or somewhat elongated, small, $0.2-0.3 \mathrm{~mm}$. wide by $0.2-0.6 \mathrm{~mm}$. long, tardily naked, firm, somewhat pulvinate, blackish brown, ruptured epidermis noticeable; teliospores angularly obovate, rounded, truncate or occasionally pointed above, usually narrowed below, $12-19$ by $26-35 \mu$, wall chestnut-brown, $1.5-2 \mu$ thick, much thicker above, $7-10 \mu$, smooth; pedicel light chestnut-brown, one to one and a half times length of spore.

On Juncus tenuis Willd., Indiana, Iowa, Wisconsin, Michigan, Minnesota, South Dakota, Missouri, New York, Maine, Massachusetts, West Virginia, Louisiana, Texas; J. dichotomus Ell., Florida.

It has been issued in the following exsiccati: aecial stage-Ellis \& Ev. Fungi Columb. 1478; Sydow, Ured. 1546; telial stage-Seym. \& Earle, Econ. Fungi 52, 528; Griffiths, W. Am. Fungi 244 (host J. tenuis not J. longistylis); Ellis \& Ev. Fungi. Columb. 2394.

The following key will serve to separate the three common species of Uromyces on Juncus, when the urediniospores are present. In the absence of uredinia the urediniospores can usually be found to some extent in telial sori, even those that have withstood the winter, and are collected in the spring following their maturity, and especially so if they are parasitized.

Urediniospores verrucose, pores 2, equatorial......U. Junci (Desm.) Tul. Urediniospores echinulate, pores 4 , equatorial........... effusus Arth. Urediniospores echinulate, pores 5-6, scattered....U. Silphii (Syd.) Arth.

3. Gymnosporangium Nelsoni Arth. - At the time this species was published it was stated that Prof. Aven Nelson, the collector of the type material, considered it highly probable that the aecia found on Amelanchier in the vicinity belonged to the species. Teliosporic material on Juniperus scopulorum Sarg., sent by Mr. E. Bethel from Colorado this spring, gave the first opportunity to test the suggestion. Sowings were made May 29 on the leaves of Amelanchier canadensis, Sorbus americana, Crataegus Pringlei, Pyrus japonica, and Aronia nigra. On June 12 a few pycnia were observed on the Amelanchier and Sorbus, but owing doubtless to indifferent growth of the hosts no aecia were formed. The other hosts remained without infection. This helps in a small way to confirm Professor Nelson's suggestion, but is not conclusive.

\section{SUMMARY.}

The following is a complete list of successful cultures made during the season of 1906 . It is divided into two series: species previously reported by the writer or other investigators, and species now reported for the first time. 
A. Species previously reported.

I. Melampsora Bigelowit Thuem. - Teliospores on Salix sp. sown on Larix decidua Mill.

2. Cronarticm Quercus (Brond.) Schroet.-Aeciospores on Pinus virginiana Mill. sown on Quercus velutina Lam.

3. Puccinia Opiziı Bubák.-Teliospores on Carex sp. sown on Lactuca canadensis L., L. virosa $L$. and $L$. sativa $L$.

4. Puccinia Sambuci (Schw.) Arth. - Teliospores on Carex Frankii Kunth sown on Sambucus canadensis L.

5. Puccinia Pecki (DeT.) Kellerm. - Teliospores on Carex trichocarpa Muhl., and also on C. lanuginosa Michx., sown on Onagra biennis (L.) Scop.

6. Puccinia albiperidia Arth. - Teliospores on Carex squarrosa L., C. tetanica Schk., and C. crinita Lam. sown on Ribes rotundifolium Michx., $R$. gracile Michx. and $R$. Cynosbati L.

7. Puccinia angustata Peck. - Teliospores on Scirpus atrovirens Muhl. sown on Lycopus americanus Muhl.

8. Puccinia Eleocharidis Arth. - Teliospores on Eleocharis palustris (L.) R. \& S. sown on Eupatorium perfoliatum L.

9. Puccinia Andropogonis Schw. - Teliospores on Andropogon scoparius Michx. sown on Pentstemon hirsutus (L.) Willd.

io. Puccinia tomipara Trel. - Teliospores on Bromus purgans $\mathrm{L}$. sown on Clematis virginiana L.

II. Puccinia subnitens Diet. - Teliospores on Distichlis spicata (L.) Greene sown on Chenopodium album L.

I2. Puccinia Poculiformis (Jacq.) Wettst. - Teliospores on Agrostis alba L. and on Elymus canadensis L. sown on Berberis vulgaris L., and aeciospores from $B$. vulgaris L. sown on Hordeum vulgare L. and Triticum vulgare Vill.

13. Puccinia transformans Ellis \& Ev. - Teliospores on Stenolobium Stans (L.) Don sown on same host.

I4. Puccinia Xanthir Schw. - Teliospores on Xanthium sp. sown on same host.

15. Puccinia Silphir Schw. - Teliospores on Silphium inegrifolium Michx. sown on S. integrifolium Michx., S. perfoliatum L., and S. terebinthinaceum Jacq.

i6. Puccinia Pruni-spinosae Pers. - Aeciospores on $\mathrm{He}$ patica acutiloba DC. sown on Prunus serotina Ehrh. and P. pumila L.

I7. Uromyces Scirpi (Cast.) Burr. - Teliospores on Scirpus fluviatilis (Torr.) A. Gray sown on Cicuta maculata L. 
Sept. 1907] Proposed Genera of Phycomycetes.

i8. Gymnosporangium Juniperi-Virginianae Schw. Teliospores on Juniperus virginiana L. sown on Malus coronaria (L.) Mill.

19. Gymnosporangium globosum Farl. - Teliospores on Juniperus virginiana L. sown on Crataegus Pringlei Sarg., Sorbus americana Marsh., and Malus coronaria (L.) Mill.

B. Species reported now for the first time.

I. Melampsora Lini (Link) Desmaz. - Teliospores on Linum usitatissimum L. sown on L. Lewisii Pursh and $L$. usitatissimum $\mathrm{L}$.

2. Uromyces Silphir (Syd.) Arth.-Teliospores on Juncus tenuis Willd. sown on Silphium perfoliatum L.

3. Gymnosporangium Nelsoni Arth. - Teliospores on Juniperus scopulorum Sarg. sown on Amelanchier canadensis (L.) Medic. and Sorbus americana Marsh.

\footnotetext{
Distributed September $12,1907$.
} 



\title{
96
}

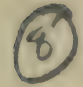

Reprinted from the Journal of Mycology, $14: 7-26$, January, 1907.

\section{CULTURES OF UREDINEAE IN $1907 .{ }^{1}$}

\author{
BY J. C. ARTHUR.
}

The present article forms the eighth of a series of reports ${ }^{2}$ by the author upon the culture of plant rusts, covering the years I 899 to the close of 1907 . The grass and sedge rusts form a prominent part of the year's work, the same as in previous seasons, but it has been possible to include also some very interesting studies of a number of species of Gymnosporangium. This was chiefly brought about by two excursions made by my colleague, Mr. F. D. Kern, and myself for the express purpose of securing this sort of culture material, and for making observations regarding probable alternate hosts. The first trip was to Lake Forest, Ill., on April 6, where we secured G. clavipes, G. clavariaeforme and $G$. nidus-avis in the locality where the last two were obtained by Dr. R. A. Harper for the distribution in Ellis \& Everhart's North American Fungi and Fungi Columbiani. Explicit directions were given us by Dr. Harper to enable us to

${ }^{1}$ Read before the Botanical Society of America at the Chicago meeting, December, 1907.

${ }^{2}$ See Bot. Gaz. $20: 268-276$, $35: 10-23$; Jour. Myc. 8:51-56, I0:8-21, $I I: 50-67,12: 11-27$ and $13: 189-205$. 
go to the right spots. The second trip was to Colorado where collections were made April 27 at Boulder, May I at Glenwood Springs and May 2 at Wolcott. Unusual success attended this search for material, due in large part to the solicitous assistance of Mr. E. Bethel, of Denver, President of the Colorado Academy of Science, who accompanied us to Boulder, and gave detailed directions for finding infested trees at the other places. Mr. Bethel's intimate knowledge of the localities, and his own extensive observations upon these and other rusts of Colorado, all being placed at our disposal, made the few days of our stay in the state remarkably rich in results. The species of Gymnosporangium and Roestelia obtained upon this trip were found upon subsequent study to be in part quite distinct from the well known species to which they have heretofore been referred, and in part entirely new discoveries. These forms have recently been named and characterized by Mr. Kern, ${ }^{3}$ and two of the species, G. Betheli and $G$. inconspicuum, have been successfully cultivated.

For the third time the Botanical Society of America generously made a grant to forward this series of studies. This year it was sufficient to pay in large part for the assistance needed in testing the viability of spores, making the sowings, and recording the results, the balance being supplied by the Indiana Experiment Station.

The work was done by Mr. Frank Vasku, a senior student of the University of Iowa, recommended by Professor T. H. MacBride. Like the two previous men from the Botanical Department of the University of Iowa, who have assisted in this work, Mr. Fred. J. Seaver in 1903 and Mr. F. D. Kern in 1904, Mr. Vasku showed exceptional skill in conducting this class of work. His quick understanding of the problems, careful and accurate manipulation, and untiring devotion, were large factors in determining the amount and value of the season's results. Most of the sowings of Gymnosporangium spores were made by $\mathrm{Mr}$. Kern, who took an especial interest in this part of the work, as it bore upon the subject of a thesis in preparation for the master's degree.

In order to study as many species as possible from a wide range of localities, and in this way to investigate the North American rust flora as a whole, it is necessary to depend upon the good will and generosity of contributors for much of the culture material and for hints regarding probable alternation of hosts. Those who have aided the work this year are Rev. J. M. Bates, Red Cloud, Neb., leading with 30 collections of culture material, and Messrs. E. Bethel, Denver, Colo., W. A. Kellerman, Columbus, Ohio, J. Dearness, London, Ont., C. W. Edgerton, Ithaca, N. Y., A. O. Garrett, Salt Lake City, Utah, H.

'Bulletin Torrey Club 34:459-463. 1907. 
D. House, Clemson College, S. C., J. J. Davis, Racine, Wis., T. D. A. Cockerell, Boulder, Colo., D. Reddick, Ithaca, N. Y., R. J. Pool, Lincoln, Neb., E. W. Olive, Madison, Wis., F. L. Stevens, West Raleigh, N. C., C. F. Baker, Santiago de la Vegas, Cuba, and Geo. W. Carver, Tuskegee, Ala. Host plants suitable to grow in pots and be used for inoculation were contributed by C. S. Sargent, Jamaica Plains, Mass., E. Bethel, Denver, Colo., and J. J. Davis, Racine, Wis. For these favors, and for the hearty co-operation of the above and other correspondents most grateful acknowledgment is here extended.

During the present season 98 collections of material with resting spores and 20 collections with active spores were employed, from which 438 drop cultures were made to test the germinating condition of the spores. Out of the 98 collections with resting spores 29 could not be brought to germination, although seemingly in perfectly healthy condition. This left 68 collections of available material, with which the cultures were made. These 68 collections belonged to 47 species of rusts, a considerable part, however, being forms whose life cycle had already been ascertained, the sowings being made for purposes of verification or extending the range of hosts. Beside these collections of resting spores sowings were made of nine species of Gymnosporangium, and of a few species of Coleosporium, Aecidium and Peridermium. Altogether 296 sowings were made, employing for the purpose II 3 species of hosts, and more than two and a half times that number of individual plants, all grown temporarily in pots, so that the work could be done in the greenhouse under perfect control. In a few cases where small potted plants were not available cuttings were used, being kept alive by frequently changing the water in which they were thrust, and successively cutting off a bit of the stem to give fresh absorbing surface. The results of this work are given in the following paragraphs, and are divided into negative results, positive results with species whose life cycles have already been ascertained by the writer or other investigators, and positive results with species whose life cycles are now first placed on record.

Of the trials giving negative results the following may be recorded to serve for reference in future studies:

I. Puccinia on Carex Pennsylvanica Lam., collected at Sargent, Neb., by Rev. J. M. Bates, was sown on Aesculus glabra, Napaea dioica, and Symphoricarpus racemosus. Another collection made near Lafayette, Ind., by Mr. Frank Vasku, was sown on Anemonella thalictroides, Ranunculus septentrionalis, Solidago Canadensis, Viola striata, and Trillium recurvatum. 
- Still a third collection made at Boulder, Colo., by the writer, was sown on Hydrophyllum capitatum, Lactuca Canadensis, Iris versicolor, Phryma leptostachya, Artemisia serrata, and A. dracunculoides. None of these sowings gave infection. Similar material had been tried on five of these hosts before, and on twentynine other species, all with negative results. ${ }^{4}$ The rust on this host is common in the northern states east of the Rocky mountains, and appears from its morphological characters to be distinct from any described form. Fifty-five sowings have now been made, beginning in 1903, using forty-three species of hosts, and as no innoculation has been effected, the necessity for careful field observations to detect the probable alternate host becomes highly imperative in order to determine the real life cycle.

2. Puccinia on Carex gravida Bailey, sent twice by Rev. J. M. Bates, first from St. Paul, Neb., was sown on Aesculus glabra, Viola cucullata, Ribes Cynosbati, and Hydrophyllum Virginicum, and second from Red Cloud, Neb., was sown on Hypoxis erecta, Houstonia purpurea, Laciniaria spicata, Lactuca Canadensis, and Artemisia dracunculoides, with no infection. Similar material from the same region has been sown in previous years upon thirty-four other species of hosts with negative results. ${ }^{5}$

3. Puccinia on Carex Douglasii Boott. collected at Valentine, Neb., by Rev. J. M. Bates, was sown on Symphoricarpus racemosus, Napaea dioica, Psoralea Onobrychis, Aesculus glabra, Laciniaria spicata, Hypoxis erecta, and Flacata comosa, with no infection.

4. Puccinia Ellisiana Thuem., on Andropogon scoparius Michx., collected at Boulder, Colo., by Mr. E. Bethel, was sown on Arabis sp., Thalictrum dioicum, Actaea alba, Psoralea Onobrychis, Polygala Senega, Viola striata, Polemonium reptans, Solidago Canadensis, Boltonia asteroides, Senecio obovatus, Lepachys pinnata, and Smilacina stellata, with no infection.

5. Puccinia virgata Ellis \& Ev., on Chrysopogon avenaceus (Michx.) Benth., collected at Grand Island, Neb., by Rev. J. M. Bates, was sown on Ceanothus Americana, Napaea dioica, Caulophyllum thalictroides, and Cassia Chamaecrista, with no infection.

- See Jour. Myc. Io:10. 1904; II:51. 1905; I2:12. 1906; and $r_{3}: 191$. 1907 .

See Jour. Myc. IO:10. 1904 II:52. 1905; and I3:191. 1907. 
6. Puccinia emaculata Schw., on Panicum capillare L., collected in the vicinity of Lafayette, Ind., by Mr. F. D. Kern, was sown on Psoralea Onobrychis, Viola cucullata, and Myosotis palustris, with no infection. This rust was sown in previous seasons on twenty other species of hosts. ${ }^{6}$

7. Puccinia Arundinariae Schw., on Arundinaria macrosperma Michx., collected at Clemson College, S. C., by Mr. H. D. House, was sown on Myrica cerifera, Ilex opaca, Smilax hispida, and Lysimachia quadrifolia, with no infection.

8. Puccinia Schedonnardi K. \& S., on Schedonnardus paniculatus (Nutt.) Trel., collected at Boulder, Colo., by Mr. E. Bethel, was sown on Napaea dioica, Sorbus Americana, Xanthoxylum Americanum, Falcata comosa, Triosteum perfoliatum, Laciniaria spicata, and Aster paniculatus, with no infection. Like material was sown in previous seasons on eleven other species of hosts. $^{7}$

9. Puccinia on Muhlenbergia tenuiflora (Willd.) B. S. P., collected at Red Cloud, Neb., by Rev. J. M. Bates, was sown on Aesculus glabra, Lepachys pinnata, Napaea dioica, Hibiscus Moscheutos, Symphoricarpos racemosus, with no infection.

io. Puccinia Crandalli Pam. \& Hume, on Festuca confinis Vasey, collected at Boulder, Colo., by Mr. E. Bethel, was sown on Draba Caroliniana, Bursa Bursa-pastoris, Cardamine bulbosa, Hydrophyllum Virginicum, Mertensia Virginica, and Cassia Chamaecrista, with no infection.

iI. Puccinia montanensis Ellis, on Elymus condensatus Presl., collected at Glenwood Springs, Colo., by Mr. F. D. Kern and the writer, was sown on Delphinium tricorne three times, with no infection. This material was found intermixed with plants of Delphinium, species undetermined, but not $D$. tricorne, which exhibited a very abundant development of Aecidium Delphinii Barth., and it was assumed that the two forms were alternates. Although the relationship was not established by the attempted culture, yet it cannot be said to be absolutely disproved, as the species of Delphinium on which the Aecidium occurred was not used.

Another collection of apparently the same species of rust found on Elymus brachystachys Scribn. \& Ball, at Eldorado Springs, Colo., by the same collectors, was sown on Delphinium tricorne, with no infection.

- See Bot. Gaz. $35: 12$. 1903; Jour. Myc. 8:52. 1902; I0:10. 1904; $12: 12.1906$; and $r_{3}: 192.1907$.

'See Bot. Gaz. 35:11. 1903 and Jour. Myc. I3:192. 1907. 
I2. Puccinia on Poa longiligula Scribn. \& Will., collected at Boulder, Colo., by Mr. E. Bethel, was sown twice on Arabis sp., with no infection. This rust was found so closely associated with aecia on a species of Arabis, that it seemed almost certainly to be genetically connected. Healthy plants of apparently the same species of Arabis were secured from Colorado, and sowings made, the spores giving strong germination, but without positive results. The grass host was determined by Mr. P. L. Ricker of the U. S. Department of Agriculture.

I3. Puccinia on Eriocoma cuspidata Nutt. (Oryzopsis cuspidata Benth.), collected at Glenwood Springs, Colo., by Mr. F. D. Kern and the writer, was sown on Phacelia bipinnatifida, Hypoxis crecta, Symphoricarpos racemosus, Mertensia sp. (from Colorado), Triosteum perfoliatum, Aquilegia coerulea, Thalictrum polygamum, Amelanchier Canadensis, Hydrophyllum Virginicum, Solidago Canadensis, Laciniaria spicata, Ranunculus recurvatus, Cassia Chamaecrista, and Psoralea Onobrychis, with no infection.

14. Puccinia on Agropyron repens (L.) Beauv., collected in Kenosha county, Wis., by Dr. J. J. Davis, was sown on Polymnia Canadensis and Hydrophyllum Virginicum, with no infection. This is a leaf rust having close resemblance to Puccinia rubigo-vera on cereals.

15. Uromyces Rhyncosporae Ellis, on Rynchospora alba (L.) Vahl., collected at London, Ont., by Mr. J. Dearness, was sown on Menyanthes trifoliata and Decodon verticillatus, with no infection.

I6. Uromyces Junci (Desm.) Tul., on Juncus Balticus Willd., collected at Scotia, Neb., by Rev. J. M. Bates, was sown on Aesculus glabra, Symphoricarpos racemosus, Napaea dioica, Silphium perfoliatum, Ranunculus recurvatus, Psoralea Onobrychis, Polygala Senega, Viola cucullata, Apocynum cannabinum, Polemonium reptans, Ambrosia trifida, Senecio obovatus, Dirca palustris, Decodon verticillatus, and Bidens frondosa, with no infection. This rust appears to be morphologically identical with the European Uromyces Junci, which has aecia upon Pulicaria dysinterica, a host that was not at hand when sowings were being made. It is clearly distinct from the rust on Juncus tenuis, Uromyces Silphii (Syd.) Arth., not only on account of its structure, but because it refuses to grow on Silphium.

i7. Uromyces Orobi (Pers.) Lev., on Lathyrus decapetalus Pursh, collected at Boulder, Colo., by Prof. T. D. A. Cockerell, was sown on Lathyrus palustris and Euphorbia Arkansana Coloradensis, with no infection. This rust is believed to be an autoecious species, and the failure to infect Lathyrus is not readily explained. 
The following species of rusts were successfully grown, and the data supplement that obtained from previous cultures of this series, or that recorded by other American or European investigators. The results with Gymnosporangium are the most considerable since the work done by Dr. Roland Thaxter, concluded at the Connecticut Experiment Station in 1890.

I. Puccinia albiperidia Arth.-Teliosporic material on Carex crinita Lam., collected in the vicinity of Lafayette, Ind., by Mr. F. D. Kern, was sown on two plants of Ribes Cynosbati on April 16, giving rise to pycnia April 25, and aecia May 6 in one case, and in the other to pycnia April 29, and aecia May $14^{8}$

2. Puccinia Caricis-Asteris Arth--Teliosporic material on a narrow leaved Carex, collected at Ithaca, N. Y. by Mr. C. W. Edgerton, was sown May 8 on Aster paniculatus, Iris versicolor, Ribes Cynosbati, and Solidago Canadensis, with infection only on the first named host, showing pycnia May I6, and aecia May 24. The collection was made adjacent to a clump of Iris versicolor, covered with aecia, and there was a possibility of genetic connection, which the culture dispels.

The 24th fascicle of Fungi Columbiani contained a specimen (No. 2366) of Carex rust labelled Puccinia tenuistipes Rostr., and collected as late as November, I906, at London, Ont. As this species of rust has its aecia on Centaurea Jacea, according to a culture made by Schröter in 1885 , and as that host is only occasionally found in North America along the seacoast, and no aecia having been seen on it in these localities, I wrote to $\mathrm{Mr}$. $\mathrm{J}$. Dearness, the collector, for further information and material. He most kindly secured viable material for me from the identical locality. This was sown May I5 on Ribes Cynosbati, Aster cordifolius, and Solidago Canadensis, with no infection. It was sown again May 25 on Aster cordifolius and Erigeron annuus, this time with the production of a few pycnia by June Io on the Aster, but without formation of aecia. Still a third essay waś made by sowing June 5 on Aster paniculatus, followed by an abundance of pycnia June 12, and aecia June 19, thus establishing the identity of the rust.

In visiting the locality in the spring of $1907, \mathrm{Mr}$. Dearness discovered that the host is not Carex varia, as published, but $C$, rosea Schk., and he has forwarded ample material to verify the determination.

In justification for the use of the name applied to the rust, Mr. Dearness writes, under date of June 22, 1907, that a collection was sent to the late Mr. J. B. Ellis in September, I889,

- For previous cultures see Jour. Myc. 8:53. 1902; I0:11. 1904; $I I: 58.1905 ; 12: 14.1906 ; 13: 196.1907$. 
who thought it might be a new species and drew up a description. Not long afterward Mr. Ellis sent his notes and material to Dr. Rostrup, of Copenhagen, Denmark, who pronounced it to be $P$. tenuistipes Rostr., by which name it has since been called. ${ }^{\circ}$

3. Puccinia Caricis (Schum.) Reb.-Teliosporic material on Carex stipata Muhl. from the vicinity of Lafayette, Ind., brought in by Mr. Frank Vasku, was sown on Urtica gracilis April 19, giving rise to pycnia April 27, and aecia May 2; while a similar collection brought in by Mr. F. D. Kern, and sown April 20, gave rise to pycnia April 27, and aecia May I.

Teliosporic material on Carex riparia Curt., collected in November, 1906, at Scotia Junction, Neb., by Rev. J. M. Bates, was sown April I3, on Ribes floridum and R. rubrum, with no infection. Another sowing was made April I9 on Urtica gracilis, giving rise to abundant pycnia April 26, and aecia May I. A second collection from the same region, taken in March, 1907, was sown April 4 on Ribes floridum, with no infection; and again April 19, on Urtica gracilis, giving rise, as in the former case, to abundant pycnia April 26, and aecia May 2. Similar material on Carex riparia from Iowa gave the same results in $1902 .{ }^{10}$

4. Puccinia angustata Peck.-Teliosporic material on Scirpus atrovirens Muhl., from the vicinity of Lafayette, Ind., brought in by Mr. Frank Vasku, was sown on Lycopus Americanus April 22, giving rise to pycnia April 29, and aecia May $7 .^{11}$

5. Puccinia fraxinata (Schw.) Arth.-A collection made in November, 1906, on Spartina cynosurcides Willd., at Red Cloud, Neb., by Rev. J. M. Bates, was sown on Fraximus lanceolata May II, giving rise to pycnia May I8. The same collector sent similar material from Grand Island, Neb., in March, 1907, which was sown on Fraximus lanceolata May 25, giving rise to pycnia May 30 , and aecia June I3. A like collection taken in April, I907, similarly sown May 8, gave pycnia May I7. These sowings were all made on cut branches placed in water, which accounts for the slow development and early termination of growth. ${ }^{12}$ 1903.

- For previous cultures see Jour. Myc. $8: 54$. 1902; Bot. Gaz. 35 :15.

${ }^{10}$ For previous cultures see Bot. Gaz. 20:270. 1900；35:16. 1903; Jour. Myc. 8:52. 1902; $12: 15.1906$.

${ }^{11}$ For previous cultures see Bot. Gaz. $29: 273.1900$; Jour. Myc. $8: 53$. 1902 ; and $13: 196.1907$.

${ }^{12}$ For previous cultures see Bot. Gaz, $29: 275$. 1900; Jour. Myc. $I I: 57.1905$; and $I 2: 16.1906$. 
6. Puccinia subnitens Diet.-Teliosporic material on Distichlis spicata (L.) Greene was sent by Rev. J. M. Bates, from Red Cloud, Neb., and sown as follows:

April 10 on Chenopodium album; April 19, pycnia; April 23, aecia. April 10 on Bursa Bursa-pastoris; April 26, pycnia; May 1, aecia. April 10 on Sarcobatus vermiculatus; no infection.

April 17 on Chenopodium album; April 28, pycnia; May 1, aecia. April 17 on Sarcobatus vermiculatus (two plants); no infection. April 25 on Chenopodium album May 6, pycnia; May 8, aecia. April 25 on Sarcobatus vermiculatus; no infection.

Another collection of the rust on the same host, obtained by the writer at Ogallala, Neb., was sown on Chenopodium album April 29, giving rise to pycnia May 9, and aecia May 13. A sowing at the same time on Sarcobatus vermiculatus, and again on two plants June I, gave no infection. It may be definitely concluded that this species of rust as it exists in Nebraska is not transferable to Sarcobatus vermiculatus. ${ }^{13}$

7. Puccinia amphigena Diet.-Teliosporic material on Calamovilfa longifolia (Hook.) Hack., collected at Burnett, Neb., by Rev. J. M. Bates, was sown on Smilax hispida May 2, giving rise to pycnia May 9, and aecia May $16{ }^{14}$

8. Puccinia Phragmitis (Schum.) Körn.-Teliosporic material on Phragmites communis Trin., collected at Scotia Junction, Neb., by Rev. J. M. Bates, was sown on Rumex crispus May I, giving rise to pycnia (date not noted) and aecia May I7. ${ }^{15}$

9. Puccinia simillima Arth.-Teliosporic material on Phragmitis communis Trin., collected at Scotia Junction, Neb., by Rev. J. M. Bates, was sown on Rumex crispus, with no infection, being mistaken for the previously mentioned species. Later it was sown on two plants of Anemone Virginiana, still with no infection. It was then sown on Anemone Canadensis June 3, giving rise to abundant pycnia June II, and aecia June I9. This is a confirmation of the restricted range of aecial host, only one species of Anemone yet being found that can be infected. ${ }^{16}$

io. Puccinia Agropyri Ellis \& Ev.-This is a very common rust of the Rocky mountain region. No culture of it has ever been tried in this country, but a collection made at Bozen, in the Austrian Tyrol, was successfully sown on Clematis Vitalba,

${ }^{18}$ For previous cultures see Bot. Gaz. $35: 19$. 1903; Jour. Myc. II :54. 1905 ; $12: 16$. 1906 ; and $13: 197$. 1907.

${ }_{14}$ For previous cultures see Bot. Gaz. $35: 20$. 1903; Jour. Myc. II :57. 1905 ; and $I 2: 16.1906$.

${ }^{15}$ For previous cultures see Bot. Gaz. $29: 269.1900$; and Jour. Myc. ९:220. 1903.

is For previous cultures see Bot. Gaz. 35:20. 1903. 
by Dr. P. Dietel in 1892. ${ }^{17}$ While in the foothills of Colorado this spring Mr. F. D. Kern and the writer observed a plant of Clematis ligusticifolia with pycnia just starting, which was growing in the midst of some species of Agropyron, heavily coated with the wintered telia of Puccinia Agropyri. Material was collected for cultures. The host was not in fruit, but is believed to be $A$. pseudorepens S. \& S. Sowing of the spores was made on Viorna Scottii May 2, sparingly giving rise to pycnia May 15, but failing to develop aecia. A sowing was made May Io on Clematis Virginiana, no plants of C. ligusticifolia being available, which gave rise to abundant pycnia May 20, and aecia May 27. This confirms the work by Dr. Dietel, and establishes the identity of the European and American form of the rust, which heretofore rested upon purely morphological grounds. This also shows that Clematis Virginiana may be a host for the species, although all collections so far reported on this host pretty certainly belong to the Bromus rust, Puccinia tomipara Trel.

iI. Puccinia poculiformis (Jacq.) Wettst.--Teliosporic material on an undetermined species of Agropyron, obtained at Lake Forest, Ill., by Mr. F. D. Kern and the writer, was sown May 17 on Berberis vulgaris, showing pycnia May 27 , and aecia June 5. Another collection on Agropyron tenerum Vasey, from Scotia Junction, Neb., by Rev. J. M. Bates, was sown in like manner April 24, showing pycnia May 3, and aecia May I4.

Aeciospores from the latter culture were sown on Avena satic'a May 25, giving rise to uredinia June $7 \cdot{ }^{18}$

12. Puccinia Pammeli (Trel.) Arth.-Teliosporic material on Panicum virgatum L., Collected at Red Cloud, Neb., by Rev. J. M. Bates, was sown on Euphorbia corollata, with no infection, and later was sown on E. marginata May 31, giving rise to pycnia June 6 , and aecia June I2. ${ }^{18}$

A number of attempts have been made to grow the teliospores of this rust upon Euphorbia marginata, but heretofore without success. In these cases the material was collected in Indiana, where E. marginata does not occur, but E. corollata is common and abundant. The material used this season gives the reverse condition: it was collected in Nebraska, where E. corollata does not occur or is rare, but E. marginata is conspicuously abundant. From cultures so far attempted there is reason to think that we have to do with physiological species. Whether

${ }^{17}$ Dietel, Ueber den Generationswechsel von Puccinia Agropvri Ell. et Ev. -Oesterr. bot. Zeitschrift $42: 261$. 1892.

${ }^{18}$ For previous cultures see Jour. Myc. 8:53. 1902; II:57. 1905; I2:17. 1906; and $I_{3}: 198.1907$.

${ }^{19}$ For previous cultures see Proc. Ind. Acad. Sci. for $I 901$ :284. 1902 ; Jour. Myc. II:56. 1905; I2:16. 1906. 
any morphological distinctions exist is yet uncertain, but none has yet been detected.

13. Uromyces acuminata Arth.- Teliosporic material on Spartina cynosuroides Willd., collected at St. Paul, Neb., by Rev. J. M. Bates, was sown twice on thrifty plants of Lysimachia quadrifolia, with no infection. It was sown on Steironema ciliata May 14, giving rise to strongly developed pycnia May 22 , and aecia May 27; while a second sowing May 30, gave pycnia June 6 , and aecia June $11 .{ }^{20}$

These results confirm the studies of previous seasons, showing that the rust called by this name in different sections of the country should be segregated into distinct species, or else into physiological species. More observations and material for cultures are required from all parts of the region east of the Mississippi river.

I4. Uromyces Scirpi (Cast.) Burr.-Teliosporic material on Scirpus fluviatilis (Torr.) A. Gray, collected at St. Paul, Neb., by Rev. J. M. Bates, was sown on Oxypolis rigidus, with no infection. It was sown on Cicuta maculata May 3, giving rise to abundant pycnia May I3, and aecia May 20, thus confirming the work of last season. ${ }^{21}$

I5. Uromyces Silphi (Syd.) Arth.-Teliosporic material on Juncus tenuis Willd., collected at Red Cloud, Neb., by Rev. J. M. Bates, was sown on Silphium perfoliatum April 23, giving rise to pycnia May 4, and aecia May II. Similar material sent by the same collector from Grand Island, Neb., was sown on another plant of the same host May 3I, giving rise as before to pycnia June 12 , and aecia June 17 . These results well confirm the work of last year. ${ }^{22}$

i6. Phragmidium speciosum Fr.-Teliosporic material on Rosa pratincola Greene (same as previously reported under the name $R$. Arkansana), collected in a meadow at Eldorado Springs (Boulder county), Colo., by the writer, was sown on Rosa pratincola May 20, giving rise to pycnia May 27 , and aecia June ${ }_{1}{ }^{23}$

i7. Gymnosporangium Juniperi - Virginianae Schw.Teliosporic material on Juniperus Virginiana L., collected at Dayton, Ind., by Mr. F. D. Kern, was sown on Crataegus punctata, with no infection, and on a cultivated apple, Malus Malus,

${ }^{20}$ For previous successful and unsuccessful cultures see Jour. Myc. I2:24. 1906 ; $I_{3}: 193.1907$.

in For previous cultures and discussion see Tour. Myc. 13:199. 1907.

${ }^{22}$ For previous cultures see Jour. Myc. 13:202. 1907. 1905.

${ }^{23}$ For previous cultures see Bot. Gaz. $35: 17$. 1903; Jour. Myc. II :53. 
April 12, giving rise to abundant pycnia April 24, but injury to the leaves prevented formation of acia. ${ }^{24}$

I8. Gyminosporangium globosom Farl.- Teliosporic material collected as in the previous instance was sown on the Wealthy variety of Malus Malus April 12, giving rise to a few pycnia April 30, and afterward to aecia first observed July 12, although appearing much earlier. ${ }^{24}$

19. Gymnosporangium Nelsoni Arth.-Teliosporic material on Juniperus scopulorum Sarg., collected at Boulder, Colo., by E. Bethel, was sown on Amelanchier intermedia Spach ( $A$. Botryapium DC., as given in Britton \& Brown's Illustrated Flora), April 16, giving rise to pycnia April 25, but further development stopped by injury to leaves.

Another collection made at the same place two weeks later by Mr. F. D. Kern was sown on A. Canadensis (L.) Medic. (plant from the Arnold Arboretum), April 30, giving rise to pycnia May 8, and aecia May 29. Another sowing was made on another plant of the same sort May 15, which gave a great abundance of pycnia May 22, and a fine development of aecia a month later, June 24. The above cultures were on leaves only. The same material was now sown on both leaves and fruit of Amelanchier erecta Blanch. (plants received from Edw. Gillett, of Southwick, Mass., under name of A. Canadensis, but identified by $\mathrm{Mr}$. W. H. Blanchard as typical $A$. erecta), May I3, and gave pycnia on upwards of thirty fruits and many leaves May 20, and the first aecia June 5, reaching full and normal maturity June 24. Another sowing was made on leaves of Sorbus Americana May 15, which gave rise to pycnia in fair amount May 21, and normally formed aecia, especially on the rachis and midribs, June 24.

The above results confirm and much extend the somewhat uncertain work of last season. ${ }^{26}$ It leaves no further doubt that Roestelia Nelsoni Arth. should be counted a synonym of $G$. Nelsoni Arth., as suggested in the original publication of the name.

20. Gymnosporangium clavipes C. \& P.-Teliosporic material on Juniperus Sibirica Burgsd., obtained at Lake Forest, III., by Mr. F. D. Kern, was sown on leaves of Amelanchier intermedia April Io, giving rise to a few pycnia May I, but without maturing aecia. Another sowing was made on fruit of $A$. erecta, also giving rise to a few pycnia June 5 , but not maturing aecia. Checking of development was doubtless due in both instances to inherent weakness of the hosts. A sowing was made on Malus coronaria and Cataegus sp., with no infection.

${ }^{24}$ For previous cultures see Jour. Myc. I2:13. 1906; I3:200. 1907.

${ }^{25}$ For previous cultures see Proc. Am. Acad. Sci. $22: 263.1887$; Bot.

Gaz. I4:167. 1889; Jour. Myc. 13:200. 1907.

See Jour. Myc. 13:203. 1907. 
Cultures of this species were made by Prof. W. G. Farlow, ${ }^{27}$ in 1883 , from teliosporic material on Juniperus Virginiana, which gave rise to pycnia on leaves of Malus Malus, Aronia arbutifolia and Amelanchier Canadensis, but failed to mature aecia. Cultures were also made by Dr. Roland Thaxter ${ }^{28}$ in 1886 , from similar material, producing pycnia on leaves of Malus Malus, and both pycnia and well developed aecia on Amelanchier Canadensis, especially on stems and midribs. A difference in the source of material used in the earlier cultures, and for the present year, is worth noting. The former was taken from Juniperus Virginiana, the red cedar, while the latter came from Juniperus Sibirica, the dwarf juniper. This is the only species of Gymnosporangium so far known to inhabit both the true cedars and the true junipers, and the situation should receive careful study. Either the species is a more generalized one than usual, which is not borne out by the geographical distribution, or it is an aggregate of two closely related forms thus far confused.

21. Gymnosporangium Clavariaeforme (Jacq.) DC.Teliosporic material on the stems of Juniperus Sibirica Burgsd., obtained at Lake Forest, I11., by Mr. F. D. Kern, was sown on leaves of Malus Malus (Bechtel Crab variety), with no infection, and also on leaves of Amelanchier intermedia April II, giving rise to a few pycnia April 20, but to no further development owing to withering of the leaves.

The first culture of this species was made in Denmark, by Oersted, in 1867. The numerous subsequent cultures by European investigators are summarized by Klebahn. ${ }^{29}$ The only definite cultures with American material were made by $\mathrm{Dr}$. Roland Thaxter, ${ }^{30}$ in 1886 and 1887 . He grew an abundance of pycnia and aecia on Crataegus tomentosa and Amelanchier Canadensis. Uncertain results were obtained in trials by Prof. L. H. Pammel. ${ }^{31}$

22. Gymnosporangium nidus-Avis Thax.-Teliosporic material on Juniperus Virginiana L., obtained at Lake Forest, Ill., by Mr. F. D. Kern, was sown on Amelanchier intermedia, with no infection, and also on Malus Malus (Whitney Crab variety) April I0, which gave rise to a few pycnia April I7, and aecia May II, a period of incubation shorter than for most Gymnosporangia. The spores for sowing were taken from large sori on the branches. The only previous cultures of this species were made by $\mathrm{Dr}$.

27 Proc. Am. Acad. Sci. $20: 313.1885$.

${ }^{28}$ Bot. Gaz. II:236. 1886; Proc. Am. Acad. Sci. $22: 264.1887$.

$\rightarrow$ Die wirtswechselnden Rostpilze, pages 339-345.

${ }^{30}$ Proc. Am. Acad. Sci. $22: 262$. 1887; and Bot. Gaz. 14:166. 1889.

n Bull. Iowa Exper. Sta. 84:33. 1905. 
Roland Thaxter, ${ }^{32}$ in an extensive series running from 1886 to $\mathrm{I} 890$, inclusive. He grew it on Amelanchier Canadensis in great abundance, showing both pycnia and aecia, and in one instance pycnia were formed on the common apple, but failed to develop further. Thaxter also noted the early development of pycnia and aecia.

The following eight species have now been grown in cultures for the first time, so far as the writer knows. The two cases of amphispores and the one autoecious species resulted as anyone might have taken for granted, but in the other five cases the results are wholly unpredicted, and represent very material advancement in the knowledge of American heteroecious rusts.

I. Puccinia vexans Farl.-Material bearing both teliospores and amphispores on Atheropogon curtipendulus (Michx.) Fourn. (Bouteloua racemosa Lag.), was sent from Boulder, Colo., by Mr. E. Bethel, and gave good germination for the amphispores, but the teliospores refused to grow. Sowing was made on Atheropogon curtipendulus May 29, and uredinia were observed June 2I, although they may have appeared earlier and been overlooked. The amphispores were the characteristic, darkcolored, thick-walled and four-pored form, while the urediniospores, to which they gave rise, had the usual light-colored, thinwalled and eight-pored appearance. The difference between the resting form (amphispore) and active form of the urediniospores belonging to this species is very striking. This is the second time, as far as the writer knows, that amphispores of this species have been seen to germinate.

2. Puccinia Cryptandri Ellis \& Barth.-Amphisporic material on Sporobolus cryptandrus (Torr.) A. Gray, obtained at Manitou, Colo., by Mr. F. D. Kern and the writer, was sown on a plant of the same species of grass May 9, and uredinia appeared May 24. In this case the difference between the resting or amphisporic form of the urediniospores and the active or summer form is not so marked as in the preceding species, and yet there is no mistaking one for the other.

3. Puccinia obtecta Peck. - Teliosporic material on Scirpus Americanus Pers., obtained near Lafayette, Ind., by Mr. F. D. Kern, was sown on Urtica gracilis, and Silphium perfoliatum, with no infection, and afterward on Bidens frondosa June 5 , giving rise to a few pycnia June 19, and aecia first noticed July 6 , but probably opening earlier. Another sowing was made on $B$. frondosa and also on $B$. connata June 24 , both showing a good devedopment of pycnia July I, and aecia July 6.

${ }^{32}$ Bot. Gaz. II :238. 1886; Proc. Am. Acad. Sci. $22: 264.1887$; Bot. Gaz. I4:167. 1889; and Bull. Conn. Exper. Sta. I07:5. 1891. 
The telial stage is common and well known throughout the United States and extending into Mexico, but the aecial stage has rarely been collected. Collections of aecia are in the writer's harbarium from Nebraska and Wisconsin, and in the literature one is also recorded from Illinois. On the basis of a single collection on Bidens frondosa Professor Burrill separated it as a special form, and De Toni, in the seventh volume of Saccardo's Sylloge, supplied the name Aecidium compositarum var, Bidentis Burrill.

4. Puccinia on Carex stenophylla.-Teliosporic material of this rust collected at Boulder, Colo., by the writer, was sown on Solidago Canadensis and Baptisia leucantha, with no infection.

It was at this point in the work that a brief note of observation was seen in Dr. W. Tranzschel's second report on "Beiträge zur Biologie der Uredineen." This is a translation in full: "In July, 1900, I found in Turkestan, near Irkeschtam on the Chinese border, the Aecidium Dracunculi Thüm. on Artemisia Dracunculus in great abundance. Associated with the affected Artemisia grew Carex stenophylla Wahlb., on which was found uredosori." Accepting this as a hint, the Colorado material was now sown on Artemisia dracunculoides. As no potted plant was available, a sowing was made in the open, giving no infection, and another in the greenhouse on a cutting placed in water. The latter attempt gave very abundant and unequivocal results. The sowing was made May 3I, and pycnia appeared June 6, followed by aecia June 15, both numerous and finely developed.

The type collection of this Aecidium was made in Siberia, at Minussinsk, also on the Chinese border, but about a thousand miles northeast of the locality where it was found by Dr. Tranzschel. This collection was distributed in Thuemen's Mycotheca Universalis, No. I223. A collection of aecia on Artemisia dracunculoides from Nebraska was distributed in Ellis \& Everhart's Fungi Columbiani, No I664. A careful comparison shows no apparent difference between the Asian and American collections, and the two are accepted as the same species.

As a name and description seem to be demanded for this species, the following are submitted:

Puccinia universalis nom. nov. (Aecidium Dracunculi Thuem., not Puccinia Dracunculi Auers.)

O. Pycnia chiefly epiphyllous, numerous in orbicular groups, punctiform, honey-yellow, rather inconspicuous; subepidermal, slightly depressed-globose, $100-160 \mu$ broad by $90-112 \mu$ high; ostiolar filaments 40 $80 \mu$ long.

I. Aecia chiefly hypophyllous, crowded in orbicular groups opposite the pvcnia, $1-3 \mathrm{~mm}$. across, peridia cylindrical, $0.5 \mathrm{~mm}$. high, margin usually erect, erose, peridial cells rhomboidal, 20-30 $\mu$ long, overlapping, 
inner wall medium thick, 3-4 $\mu$, verrucose, outer wall thicker, $5-9 \mu$, smooth, striate; aeciospores globoid, small, $12-18$ by $15-21 \mu$; wall very thin, $0.5-1 \mu$, nearly colorless, very minutely granular.

On Artemisia dracunculoides Pursh, Colorado, Nebraska; A. Canadensis Michx., Iowa, Nebraska; $A$. frigida Willd., Montana; $A$. kansana Britt., Nebraska. Type on A. Dracunculus L., Western Siberia.

II. Uredinia epiphyllous, scattered, oblong, 0.2-0.5 mm. long, rather early naked, cinnamon-brown, ruptured epidermis conspicuous; urediniospores broadly ellipsoid, $15-19$ by $20-26 \mu$, wall cinnamon brown, $1-1.5 \mu$ thick, rather finely echinulate, pores 2 , equatorial.

III. Telia epiphyllous, scattered, roundish or oblong, $0.1-0.3 \mathrm{~mm}$. wide by $0.2-1.2 \mathrm{~mm}$. long, early naked, pulvinate, ruptured epidermis noticeable; teliospores clavate-oblong, $16-26$ by $35-52 \mu$, wall dark chestnut-brown, lighter and about 1.5-2 $\mu$ thick below, thicker above, 7-12 $\mu$, smooth; pedicel tinted, one-half length of spore, or more.

On Carex stenophylla Wahl., Colorado, Nebraska, Montana.

5. Puccinia on Carex longirostris.-Field observations by Dr. E. W. Olive, and material furnished by him, including aecia host plants, supplied the entire basis for the result reported under this number.

Teliospores from Carex longirostris Torr. were sown June 4 on Aster paniculatus, Erigeron annuus, Solidago Canadensis, Ribes Cynosbati, and Phryma leptostachya, with no infection, except on Phryma, which showed pycnia June Io in great. abundance, and aecia June 15. The development was exceptionally strong and characteristic.

No rust has heretofore been reported on this species of Carex. The aecial stage was first collected at Spirit Lake, Iowa, by Dr. B. D. Halsted, in 1886 , and has since been reported from Minnesota and Nebraska, and found by Dr. Olive this season at Madison, Wis. A description of the species in its several spore-stages is appended:

Puccinia Phrymae (Halst.) nom. nov. (Aecidium Phrymae Halst., Jour. Myc. 2:52. 1886.)

O. Pycnia amphigenous, few, crowded in small groups, inconspicuous, honey-yellow, becoming blackish-brown, slightly flatteried globoid, 77-110 $\mu$ in diameter by $65-80 \mu$ high; ostiolar filaments $40-50 \mu$ long.

I. Aecia hypophyllous, gregarious, in large open groups on discolored spots $4-10 \mathrm{~mm}$. across, very short, $0.2-0.3 \mathrm{~mm}$. in diameter, pale yellow; peridia colorless, margin recurved, erose, peridial cells thomboidal in longitudinal section, overlapping, inner wall thin, about $1 \mu$, finely verrucose, outer wall thicker, 3-4 $\mu$, striate, smooth; aeciospores globoid, 12-16 by $14-19 \mu$, wall pale yellow, thin, $1 \mu$ or less, finely verrucose.

On Phryma leptostachya L., Iowa, Wisconsin, Nebraska, Minnesota. Type from Spirit Lake, Iowa.

II. Uredinia hypophyllous, scattered, round or oblong, early naked, ruptured epidermis noticeable; urediniospores broadly ellipsoid, 15-18 by 18-20 $\mu$, wall cinnamon-brown, $1-1.5 \mu$ thick, finely and rather sparsely echinulate, pores 2, in upper part. 
III. Telia hypophyllous, scattered, round or oblong, 0.2-0.4 mm. wide by $0.3-0.8 \mathrm{~mm}$. long, early naked, dark chocolate-brown, pulvinate, ruptured epidermis noticeable; teliospores clavate-oblong, $12-15$ by $35-45 \mu$, rounded or obtuse at apex, usually narrowed below, wall chestnut-brown, concolorous, $1-1.5 \mu$ thick, much thicker above, $9-13 \mu$ : pedicel about length of spore or less, tinted.

On Carex longirostris Torr., Wisconsin.

6. Puccinia mutabilis Ellis \& Gall.-While collecting for a few days in Colorado about the first of May, wintered-over teliospores were found on a number of species of Allium, in most cases not accurately determined for want of the inflorescence. In a few cases young leaves of the season showed freshly formed uredinia, and in one instance immature telia were observed beside the uredinia, evidently arising from the same mycelium. A few very young aecia, well isolated from other spore forms were also found. As it was clearly too early in the season to have had aecia mature and reinfect the host, and in this manner give rise to the uredinia, the question arose whether the aecia did not belong to some heteroecious species, while the uredinia and telia represented a species without aecia. Further search in the field brought to light some leaves which without question had remained alive over winter. In one case the dead tip of such a leaf bore telia of last year's growth, and on the adjoining green part of the leaf uredinia were forming. This seemed to show that the early uredinia were derived from wintered-over mycelium, but it left the question of the origin of the aecia unsolved.

Teliosporic material on what was believed to be Allium reticulatum Fraser, was obtained by the writer at Eldorado Springs, Colo., and sown on Allium recurvatum Rydb., May I8, giving rise to pycnia June 3 , and aecia June 7 . The life cycle of the rust with all spore forms is therefore established, although it is clearly possible in exceptional cases for the mycelium to be carried over the winter in leaves that retain their vitality and thus start the rust in the spring at the uredinial stage.

7. Gymnosporangium Betheli Kern. - Teliosporic material on Juniperus scopulorum Sarg., obtained at Boulder, Colo., by Mr. F. D. Kern, was sown on Crataegus sp. (received from the Arnold Arboretum) April 30, showing pycnia May 8 , and aecia June 5 , the aecia being fully matured by June 17. Another sowing was made on Crataegus coccinea May ${ }^{5}$, showing pycnia May 21, and aecia June 24. Another sowing on Crataegus punctata May I5, gave pycnia May 2I, but the leaves withered before aecia had formed. Another sowing on Sorbus Americana May 21, gave rise to numerous pycnia May 29 , and an equal abundance of well formed aecia July 25 . 
Similar material obtained at Wolcott, about one hundred miles west of Boulder, was sown on Crataegus cordata (Mill.) Ait. May 5, on a tree out of doors, giving rise to pycnia May I7, and aecia July I. Another sowing on Sorbus Americana May I5, gave a large number of pycnia May 24, and aecia well formed July 25. A sowing on Amelanchier erecta gave no infection.

All the foregoing sowings were on the leaves. The ample success attained admits of no question that the aecia, recently described under the name Roestelia Betheli Kern, do in fact belong to the large gall form of cedar rust, as suggested by Mr. E. Bethel $^{38}$ from field observations.

8. Gymnosporangium inconspicuum Kern. - Teliosporic material on Juniperus Utahensis (Engelm.) Lemmon, obtained from the type locality at Glenwood Springs, Colo., by Mr. F. D. Kern and the writer, was sown on the leaves of Crataegus sp., Amelanchier Canadensis, and Pyrus communis, with no infection. It was afterward sown on fruit of Amelanchier erecta May I0, which gave rise to abundance of pycnia May 24, and aecia June 15, the aecia being mature by June 19. The affected areas of the fruit became somewhat swollen, and of a yellowish white color, making them conspicuous. The aecia prove to be identical with Roestelia Harknessianoides Kern, and thus confirm the inference drawn from field observations. ${ }^{34}$ It is an interesting fact that while the telia of this species of rust are very evanescent, the aecia persist and may be found on mummified fruits the year following infection, so that it is likely to become common in herbaria.

\section{SUMMARY.}

The following is a complete list of successful cultures made during the season of 1907 . It is divided into two series: species previously reported by the writer or other investigators, and species now reported for the first time.

\section{A Species previously reported.}

I. Puccinia atbiperida Arth.-Teliospores on Carex crinita Lam., sown on Ribes Cynosbati L.

2. Puccinia Caricis-Asteris Arth. - Teliospores on Carex rosea Schk., sown on Aster cordifolia L., and on Carex sp., sown on Aster paniculatus Lam.

3. Puccinia Caricis (Schum.) Reb. - Teliospores on Carex stipata Muhl., and on C. riparia Curt., sown on Urtica gracilis Ait.

Bull. Torrey Club 34:460. 1907.

a Bull. Torrey Club 34:463. 1907. 
4. Puccinia angustata Peck. - Teliospores on Scirpus atrovirens Muhl., sown on Lycopus Americanus Muhl.

5. Puccinia fraxinata (Schw.) Arth. - Teliospores on Spartina cynosuroides Willd.,sown on Fraximus lanceolata Borck.

6. Puccinia subnitens Diet. - Teliospores on Distichlis spicata (L.) Greene, sown on Chenopodium album L., and Bursa Bursa-pastoris (L.) Britt.

7. Puccinia amphigena Diet. - Teliospores on Calamorilfa longifolia (Hook) Hack., sown on Smilax hispida Muhl.

8. Puccinia Phragmitis (Schum.) Körn. - Teliospores on Phragmites communis Trin., sown on Rumex crispus $\mathrm{L}$.

9. Puccinia simillima Arth.-Teliospores on Phragmites communis Trin., sown on Anemone Canadensis L.

io. Puccinia Agropyri Ellis and Ev.- Teliospores on $A g$ ropyron pseudorepens S. \& S., sown on Viorna Scottii (Porter) Rydb., and on Clematis Virginiana L.

i I. Puccinia poculiformis (Jacq.) Wettst. - Teliospores on Agropyron tenerum Vasey, sown on Berberis vulgaris L., and aeciospores from this culture sown on Avena sativa L.

i2. Puccinia Pammeli (Trel.) Arth. - Teliospores on Panicum virgatum L., sown on Euphorbia marginata Pursh.

13. Uromyces acuminatus Arth. - Teliospores on Spartina cynosuroides Willd., sown on Steironema ciliata (L.) Raf.

14. Uromyces Scirpi (Cast.) Burr.-Teliospores on Scirpus fluviatilis (Torr.) A. Gray, sown on Cicuta maculata L.

15. Uromyces Silphil (Syd.) Arth.-Teliospores on Juncus tenuis Willd., sown on Silphium perfoliatum L.

i6. Phragmidium speciosum Fr.-Teliospores on Rosa pratincola Greene, sown on same host.

i7. Gymnosporangium Juniperi-Virginianae Schw.Teliospores on Juniperus Virginiana L., sown on Malus Malus (L.) Britt.

18. Gymnosporangium globosum Farl. - Teliospores on Juniperus Virginiana L., sown on Malus Malus (L.) Britt.

19. Gymnosporangium Nelsoni Arth. - Teliospores on Juniperus scopulorum Sarg., sown on Amelanchier intermedia Spach, A. Canadensis (L.) Medic., A. erecta Blanch., and Sorbus Americana Marsh. 
20. Gymnosporangium clavipes C. \& P.-Teliospores on Juniperus Sibirica Burgsd., sown on Amelanchier intermedia Spach, and $A$. erecta Blanch.

21. Gymnosporangium Clavariaeforme (Jacq.) DC.Teliospores on Juniperus Sibirica Burgsd., sown on Amelanchier intermedia Spach.

22. Gymnosporangium nidus-Avis Thax.-Teliospores on Juniperus Virginiana L., sown on Malus Malus (L.) Britt.

B. Species reported now for the first time.

I. Puccinia vexans Farl.-Amphispores on Atheropogon curtipendulus (Michx.) Fourn., sown on same host.

2. Puccinia Cryptandri Ellis \& Barth.-Amphispores on Sporobolus cryptandrus (Torr.) A. Gray, sown on same host.

3. Puccinia obtecta Peck.-Teliospores on Scirpus Americanus Pers., sown on Bidens frondosa L., and B. connata Muhl.

4. Puccinia universalis Arth.- Teliospores on Carex stenophylla Wahl., sown on Artemisia dracunculoides Pursh.

5. Puccinia Phrymae (Halst.) Arth.-Teliospores on Carex longirostris Torr., sown on Phryma leptostachya L.

6. Puccinia mutabilis Ellis \& Gall.-Teliospores on Allium reticulatum Fraser, sown on $A$. recurvatum Rydb.

7. Gymnosporangium Betheli Kern.-Teliospores on Juniperus scopulorum Sarg., sown on Crataegus coccinea L., C. punctata Jacq., C. cordata (Mill.) Ait., and Sorbus Americana Marsh.

8. Gymnosporangium inconspicuum Kern.-Teliospores on Juniperus Utahensis (Engelm.) Lemmon, sown on Amelanchier erecta Blanch. 


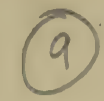

\section{CULTURES OF UREDINEAE IN $1908^{1}$}

J. C. Arthur

The present article forms the ninth of a series of reports ${ }^{2}$ by the author upon the culture of plant rusts, covering the years from 1899 to the close of 1908 . The grass and cedar rusts have been especially prominent in the years' work. Very considerable advance has been made in segregating the subepidermal rusts on grasses that have generally passed under the name of Puccinia rubigo-vera, and some particularly notable results were achieved with forms of Gymnosporangium, partly in finding unexpected aecial connections for well-known telial species, and partly in segregating species heretofore confused under European names.

This year for the first time since the series of cultures was begun, the Indiana Experiment Station at Purdue University, where all the study has been conducted, assumed the full expense of the work. Heretofore the extra assistance needed during the chief cultural period of about six weeks has been paid for in part or wholly from outside sources. This year the cultural work was made a part of an extended investigation of cereal and other rusts to be conducted by the station, and the expenses met from the Adams fund, derived from the general govermment. The more definite and certain financial support has made it possible to better systematize and conduct the work.

As in the previous year some collecting trips made expressly

${ }^{1}$ Read before the Botanical Society of America at the Baltimore meeting, December 31, 1908.

${ }^{2}$ See Bot. Gaz. 29: 268-276, 35: 10-23; Jour. Myc. 8: $5^{1-56}$, 10: 8-21, II: $50-67,12: 11-27,13: 189-205$, and 14: $7-26$. 
to secure culture material proved helpful to an extent far beyond the proportional amount of time consumed. The earliest one took Mr. F. D. Kern and the writer to Mammoth Cave in Kentucky. It was specifically undertaken to discover a telial form to accompany the aecia known to occur on Porteranthus stipulatus (Gillenia stipulacea). A careful microscopic examination made during the winter of $1907-8$ of the aecia on this host, which were collected by Rev. C. H. Demetrio in 1884 at Perryville, Mo., and distributed as No. 3323 in Rabenhorst-Winter, Fungi europaei, under the name of Roestelia lacerata, which it much resembles, showed that the fungus was undoubtedly a true Roestelia, although the host is an herb belonging to the rose family. As this is the only known instance of the aecial stage of a Gymnosporangium occurring on any host outside of the woody plants of the apple family, the detection of the telial form appeared to be a matter of more than usual interest. The original collection was apparently the only one known, until a search was made through the phanerogamic herbaria in a number of places, and a few pycnia were detected on a collection of the host at the New York Botanical Garden, which was made at Mammoth Cave, in June, I87o, by Dr. T. F. Allen. Upon writing to Rev. Demetrio it was learned that the locality of the original collection has been turned into cultivated fields, quite destroying the chances of making a second collection in the original habitat. It was known to the writer that the estate of several thousand acres about the Mammoth Cave has been in litigation for a number of years, and that few changes have taken place in the long period during which the cave has been an object of world-wide interest to tourists. After considering these facts it was decided to visit the vicinity of the cave, hoping to detect material from which cultures could be made. Two days were spent at the cave. The most careful search on the first day was in vain, although the host was found as tender shoots only a few inches high, and also an abundance of red cedar trees. The second day afforded better success, and considerable material of what appeared to be a new form of Gymnosporangium was discovered on the trunks of small cedars growing near plants of Porteranthus, although pycnia and aecia could not be expected owing to the earliness of the season. Sub- 
sequent cultures confirmed the inferences from field observation, and abundantly justified the method pursued in this case in tracing the life history of a little or imperfectly known rust.

The next important excursion to points outside of the state of Indiana was made by my associate, Mr. F. D. Kern, the writer's ill health preventing further active participation in securing material for the work of the season. Mr. Kern reached Denver, Colo., on May I6, and spent five days collecting material and making field observations chiefly along the foot hills from Boulder on the north to Trinidad on the south. During this time he had the invaluable assistance of Mr. E. Bethel, the able mycologist of Denver, who supplied important information about suitable localities to visit, and for part of the time himself went along to help in every way possible. The results fully justified the time and outlay, especially in the way of knowledge regarding the numerous and intricate forms of cedar rusts. The telia of the true Roestelia cornuta were collected on this trip for the first time in America. The telia of the true $R$. penicillata, little known in America, were also taken, but owing to misfortune in manipulation did not lead to successful cultures.

On his return journey from Colorado Mr. Kern made a detour to Racine, Wis., where as the guest of Dr. J. J. Davis he visited in an automobile the Wind Lake locality, made familiar to mycologists by Dr. Davis' numerous collections and observations. Here material was obtained of the juniper rust, believed to be associated with the cornuta-like aecia on Aronia. It had been sent by Dr. Davis for cultures in previous years, but had not been brought to germination. This is the type locality for the species, to which Mr. Kern has given the name Gymnosporangium Davisii. ${ }^{3}$

At our request Mr. H. S. Jackson, of Newark, Del., made some fruitful collecting tours for observations on the Atlantic coast rusts. A two days' trip to Seaford and Lewes, Del., was made the middle of November, I907, and again to the same places the latter part of April following. The duplicate trip was especially designed to secure observations on the early appearance of aecia in the immediate vicinity where telial culture material had pre-

${ }^{8}$ Bull. Torrey Club 35: 507. x908. 
viously been taken. Mr. Jackson proved a keen observer, detecting a new species on Carex comosa with its probable aecia on Smilax, and both aecia and telia of Puccinia subnitens, the first collection of it made on the Atlantic coast, beside much other serviceable information. He also made a trip to Newfield, N. J., on May I5, and secured telial material of cedar rusts from the region made familiar by the late Mr. J. B. Ellis.

The season's cultural work was, with the exception of some cedar rust cultures made by Mr. Kern, in the hands of Mr. A. G. Johnson, a graduate of the South Dakota Agricultural College, and a former special student of Washington University, St. Louis, who was recommended for the position by Dr. E. W. Olive. He was diligent and enthusiastic in the work, and made successful cultures of the largest number of species secured in any one season during the ten years that the cultural work has been in progress.

In this series of studies the amplitude of the results is largely dependent upon the kindly assistance of correspondents in providing culture material and in communicating field observations. Acknowledgments are due this year to Mr. E. Bethel, Denver, Colo., who is far in the lead with more than fifty collections of culture material, and to Messrs. H. S. Jackson, Newark, Del., J. M. Bates, Red Cloud, Neb., R. E. Stone, Auburn, Ala., A. O. Garrett, Salt Lake City, Utah, Elam Bartholomew, Stockton, Kans., E. W. Olive, Brookings, S. D., E. W. D. Holway, Minneapolis, Minn., H. J. Webber, Ithaca, N. Y., T. D. A. Cockerell, Boulder, Colo., J. L. Sheldon, Morgantown, W. Va., A. B. Seymour, Cambridge, Mass., G. P. Clinton, New Haven, Conn., P. B. Kennedy, Reno, Nev., Guy West Wilson, Fayette, Iowa, George L. Potter, Lima, Ind., J. J. Davis, Racine, Wis., A. R. Sweetser, Eugene, Ore., C. W. Edgerton, Donald Reddick and C. J. Humphrey, all three of Ithaca, N. Y., W. A. Kellerman, at the time in Guatemala, C. G. Lloyd, Zacatecas, Mex., and J. Dearness, London, Ont. This enumeration gives scanty credit where in many cases special trips, often of many miles, were undertaken at our request to secure at a definite time either dry material or live hosts, or to make observations, which would further a particular inquiry. Mention should also be made of 


\section{Arthur: Cultures of Uredineae in igo 8}

the assistance rendered by Dr. Wm. Trelease, of the Missouri Botanical Garden, St. Louis, Mo., who sent plants of Porteranthus stipulatus on which the new cedar rust was sown. The writer extends his warmest thanks to the above individuals and to others who have assisted in the year's investigations.

During the present season 204 collections of material with resting spores and 26 collections with active spores were employed, from which 565 drop cultures were made to test the germinating condition of the spores. Out of the 204 collections with resting spores 99 could not be brought to germination although seemingly in perfect condition leaving 105 collections of available material. These I05 collections with resting spores and 26 with active spores belonged to about 60 species of rusts. Altogether $32 \mathrm{I}$ sowings were made, employing for the purpose II4 species of hosts, these being grown in pots, so that the work of attempted infection could be conducted wholly in the greenhouse.

The results of this work are given in the following paragraphs, and are divided into negative results, positive results with species whose life cycles have already been ascertained by the writer or other investigators, and positive results with species whose life cycles are now first placed on record.

Negative RESUlts:-Quite a number of collections gave good germination of the spores, but no infections were secured. The following may be recorded to serve for reference in future studies:

I. Puccinia on Carex pennsylvanica L., collected at Red Cloud, Neb., by Rev. J. M. Bates, was sown on Arabis Holboellii, with no infection. Similar material was sown in previous seasons on thirty-eight other species of hosts. ${ }^{4}$

2. Puccinia vulpinoidis Diet. \& Holw., on Carex vulpinoidea Michx., collected at Newark, Del., by Mr. H. S. Jackson, was sown on Viola cucullata, Chelone glabra, Aster paniculatus, Ambrosia trifida, Cacalia reniformis, Laciniaria punctata, Rudbeckia laciniata and Senecio obovatus. A similar collection made at London, Ontario, by Mr. J. Dearness, was sown on Callirrhoe involucrata and Rudbeckia laciniata. Still a third collection made

'See Jour. Myc. 10: 10. 1904; II: 51. 1905; 12: 12. 1906; 13: I91. 1907; and 14: 9. 1908. 
by the writer at Lima, Ind., was sown on Napaea dioica, Ambrosia trifida, Aster Drummondii, Boltonia asteroides, Cacalia reniformis, Laciniaria spicata, Rudbeckia laciniata and Senecio obovatus. None of the trials resulted in infection.

3. Puccinia on Carex gravida Bailey, sent by Rev. J. M. Bates from Red Cloud, Neb., was sown on Abronia umbellata, Vernonia arkansana, and twice on Artemisia dracunculoides, with no infection. Similar material from the same region has been sown in previous years upon forty-four other species of hosts with negative results. ${ }^{5}$

4. Puccinia on Carex sp., sent by Mr. C. W. Edgerton from Ithaca, N. Y., was sown on Iris versicolor twice, with no infection. This was the culmination of a series of observations to ascertain the telial form belonging to aecia on Iris, which had been noticed for a number of seasons in one locality near the town of Ithaca. Four collections taken from the close vicinity of the rusted Iris were sent for trial in 1907, two of which grew well on Aster paniculatus, but not on Iris, while the other two failed to germinate. All four of these collections agreed morphologically with Puccinia Caricis-Asteris Arth. In continuation of the search for the true alternate form for the Iris rust, Mr. Edgerton sent this season from practically the same spot a rust on an undetermined Carex, having morphological characters quite unlike those of $P$. Caricis-Asteris, and approximating, if not identical with, $P$. quadriporula Arth. As no positive results were obtained from this material the identity of the alternate form of the aecial rust on Iris still remains in doubt.

5. Puccinia Dulichir Syd., on Dulichium arundinaceum (L.) Britt., collected at Seaford, Del., by Mr. H. S. Jackson, was sown on Decodon verticillatus, Smilax hispida, Lysimachia quadrifolia and Senecio obovatus, with no infection.

6. Puccinia emaculata Schw., on Panicum capillare L., collected at Fayette, Iowa, by Prof. Guy West Wilson, was sown on Macrocalyx Nyctelea, Hydrophyllum virginicum, Amorpha fruticosa, and Napaea dioica, with no infection. Similar material was sown in previous seasons on twenty-three other species of hosts. ${ }^{\circ}$

BSee Jour. Myc. 10: I0. I904; II: 51. 1905; 12: 12. 1906; 13: I9I. 1907; and 14: 10. 1908. 
7. Puccinia Schedonnardi K. \& S., on Schedonnardus paniculatus (Nutt.) Trel., collected at Boulder, Colo., by Mr. E. Bethel, was sown on Thalictrum polygamum and Grindelia squarrosa, with no infection. Like material was sown in previous seasons on eighteen other species of hosts. ${ }^{7}$

8. Puccinia Ellisiana Thüm., on Andropogon scoparius Michx., collected at Newark, Del., by Mr. H. S. Jackson, was sown on Actaea alba, Ambrosia trifida, Anemone virginiana, Dirca palustris, Hydrophyllum virginicum, Ipomoea pandurata, Isopyrum biternatum, Iva frutescens, Pentstemon hirsutus, Phacelia bipinnatifida, Psoralea Onobrychis and Verbena urticifolia, with no infection. Similar material from Colorado was sown the previous year on ten other species of hosts. ${ }^{8}$

9. Puccinia vexans Farl., on Atheropogon curtipendulus (Michx.) Fourn. (Bouteloua racemosa Lag.), collected at Stockton, Kans., by Mr. E. Bartholomew, was sown on Apocynum cannabinum, Caulophyllum thalictroides, Dalea laxiflora, Delphinium tricorne, Hydrophyllum virginicum, Napaea dioica, Polemonium reptans, Symphoricarpos racemosus, Smilax hispida and Thalictrum dioicum, with no infection. This is the first time that an attempt at infection with teliospores has been made, although the amphispores were successfully grown on the same grass host last year.

io. Puccinia poculiformis (Jacq.) Wettst., on Phleum pratense L., collected at Sayre, N. Y., by Prof. H. J. Webber, was sown May I on Berberis vulgaris. Another collection of the rust from Ithaca, N. Y., sent by Mr. Donald Reddick, was sown May 6 on five plants of Berberis vulgaris, and once more on May 13. As no infection showed after the usual interval, the same material was again sown May 22 on three plants of the barberry, and for three successive nights after sowing the inoculated plants were placed in an ice box at a temperature of $10^{\circ} \mathrm{C}$. in order to insure more favorable conditions for the penetration of the germ tubes into the tissues of the host. Again on May 28

- See Bot. Gaz. 35: 12. 1903; Jour. Myc. 8: 52. 1902; 10: 10. 1904; 12: 12. 1906 ; 13: 192. 1907; and 14: I1, 1908.

${ }^{7}$ See Bot. Gaz. 35: II. 1903; Jour. Myc. 13: 192. 1907; and 14: II. 1908.

${ }^{8}$ See Jour. Myc. 14: ז0. I908. 
the same material was sown on Mahonia Aquifolium. In each instance the ready germination of the teliospores was established by a drop culture within twenty-four hours preceding the time of sowing, as is done for all the culture work reported in this and preceding years. In no case was an infection secured.

The reasons for believing that this rust should be referred to Puccinia poculiformis, in spite of the failure to produce aecia on Berberis or Mahonia, have been briefly stated by Mr. Frank D. Kern, ${ }^{\ominus}$ who has also recorded the history of the appearance of the rust in North America, and it is only necessary that the writer affirm his agreement with Mr. Kern's conclusions.

iI. Puccinia Asteris Duby, on Aster arenarioides D. C. Eaton, sent from Salt Lake City, Utah, by Mr. A. O. Garrett, was sown on Aster Drummondii, A. paniculatus, A. multiflorus and Callistephus hortensis, with no infection. This adds little to the solution of the problem whether the leptopuccinial rust on various species of Aster in the different sections of the country are all referable to one species or not.

12. Uromyces graminicola Burr., on Panicum virgatum L., collected at Stockton, Kans., by Mr. E. Bartholomew, was sown on Althaea rosea, Apios tuberosa, Cacalia reniformis, Callirrhoe involucrata, Decodon verticillatus, Hibiscus militaris, Napaea dioica and Viola cucullata, with no infection.

13. Uromyces Andropogonis Tracy, on Andropogon glomeratus (Walt.) B.S.P., collected at Lewes, Del., by Mr. H. S. Jackson, was sown on Viola cucullata, while a similar collection on the same species of host, sent from Auburn, Ala., by Mr. R. E. Stone, was sown twice on Viola cucullata, and also on Comandra umbellata, Dasystoma flava and Pentstemon hirsutus, all with no infection. From the field observations reported by Dr. John L. Sheldon it seems almost certain that the aecia of this rust occur upon Viola, and the repeated failure of the cultures may have been due to the maturity of the Viola leaves on which the sowings were made.

Successful CUltures SUPPLEMENTING PREvious WORK:The following species of rusts were successfully grown, and the facts supplement what have been obtained from previous cultures

'Kern. The Rust of Timothy. Torreya 9: 3-5. 1909. 
in this series or have been recorded by other American or European investigators. In a number of cases the previous definite knowledge of the species has been materially extended.

I. Puccinia Kuhniae Schw., on Kuhnia Hitchcockii A. Nelson, collected at Marshall, Colo., Feb. 22, I908, by Mr. E. Bethel, was sown May I4, on Kuhnia eupatorioides. Numerous pycnia appeared May 24, duly followed by abundant uredinia June 4, and telia June 29. This result confirms the work in $1905,{ }^{10}$ and shows that in all probability all collections of rust on this genus of hosts are referable to the one autoecious species.

2. Puccinia Peckir (DeT.) Kellerm., on Carex stipata Muhl., collected Oct. 23, 1907, at Lima., Ind., by Mr. George L. Potter, was sown on Onagra biennis (L.) Scop., April 28, and gave pycnia May 9 and aecia May 18, both in great abundance. ${ }^{11}$

3. Puccinia Sambuci (Schw.) Arth., on Carex lurida Wahl., collected at Lagrange, Ind., by the writer, was sown on Sambucus canadensis L. May 15 , and gave a great abundance of pycnia May 23 , and aecia June $I_{.}{ }^{12}$

4. Puccinia Caricis-Solidaginis Arth., on Carex sparganioides Muhl., collected at Lima, Ind., and again at Lagrange, Ind., both by the writer, was sown from the first named locality April II on Aster Drummondii, giving no infection and again May 4 on Solidago canadensis L., giving abundant infection with pycnia showing May I2, and aecia May I9. From the second locality sowings were made April 15 on Aster paniculatus and Solidago canadensis, giving no infection on the first host, but abundant infection on the second, showing pycnia April 23, and aecia May $5 .^{13}$ This result duplicates that obtained in 1905.

5. Puccinia Eleocharidis Arth., on Eleocharis palustris (L.) R. \& S., obtained at Lima, Ind., by the writer, was sown on Eupatorium perfoliatum L., May I3, giving rise to pycnia May 22,

${ }^{10}$ Jour. Myc. 12: 23. 1906.

${ }^{11}$ For previous cultures see Bot. Gaz. 35: 13. 1903; Jour. Myc. 8: 55 . 1902; II: 58. 1905; 12: 15. 1906; and 13: 195. 1907.

${ }^{12}$ For previous cultures see Bot. Gaz. 35: 14. 1903; Jour. Myc. 8: 55. 1902; 12: 14. 1906; and 13: 195. 1907.

${ }^{13}$ For previous cultures see Bot. Gaz. 35: 21. I903; and Jour. Myc. 12: 15. 1906. 
and aecia June 2, both in abundance, thus confirming the work of 1905 and $1906 .{ }^{14}$

6. Puccinia angustata Peck, on what was probably Scirpus cyperinus (L.) Kunth, the plant showing only leaves but growing with plants with fruit, gathered at Spirit Lake, Iowa, by the writer, was sown April I3 on Lycopus communis Bickn., giving rise to pycnia April 25, and aecia May 3, both in abundance. It was sown again May 2 on Lycopus americanus Muhl., giving rise to an equal abundance of pycnia May II, and of aecia May 19, the interval between the appearance of pycnia and aecia being exactly the same as in the first culture. ${ }^{15}$ The result is interesting in connection with an observation made by the writer while on an excursion in the vicinity of Ithaca, N. Y., June 30, 1906. An abundance of rusted Lycopus communis was gathered, with uredinia appearing on close-by plants of Scirpus cyperinus, while plants of $L$. americanus and $S$. atrovirens growing intermixed were both quite free from rust. The field observation seemed to indicate a biological difference between the rust occurring on the two species of Scirpus and the associated Lycopus, and with a view to experimental tests healthy plants of $L$. communis from the Ithaca locality were sent to the greenhouse at Lafayette, the species not occurring in Indiana or Iowa. These were the plants used in the present cultures. The results seem to warrant the tentative conclusion that P. angustata within some geographical areas is inclined to form races confined to certain hosts, while in other geographical areas the differentiation into races does not occur, a condition that appears to arise in other species as well, e. g., Puccinia subnitens Diet.

7. Puccinia subnitens Diet., on Distichlis spicata (L.) Greene, was available in two collections from Delaware, two from Nebraska and two from Nevada, representing three areas approximately on the fortieth parallel of latitude, but twelve hundred miles between stations in longitude. The Delaware station is on the Atlantic sea coast; the Nebraska station is midway of the continent on the great plains, with the Allegheny range of

"For previous cultures see Jour. Myc. 12: 23. 1906; and 13: 197. 1907.

${ }^{16}$ For previous cultures see Bot. Gaz. 29: 273. 1900; Jour. Myc. 8: 53. I902; II: $58.1905 ; 13: 196.1907$; and 14: 14. 1908. 
mountains intervening; while the Nevada station is within two hundred miles of the Pacific coast, and between it and the Nebraska station intervenes the great expanse of the Rocky Mountains.

The chief question demanding solution was whether this remarkable heteroecious rust, which forms aecia on many species of hosts belonging to the families Cruciferae, Chenopodiaceae and Capparidaceae, has developed biological differences, as previous work had indicated. ${ }^{16}$ In all thirty sowings were made. A few of these proved failures because the plants used as hosts did not grow well. The important results may be given without recording all the data.

The collections from the Atlantic coast, the first reported from east of the Mississippi river, were made by Mr. H. S. Jackson, at Lewes, Del., Nov. 16, 1907. Aecia were taken the following spring in close proximity on seedling plants, which were fruited in Lafayette, and ascertained to be Atriplex hastata. Ten sowings were made from these collections, using Chenopodium album, C. hybridum, Iva frutescens on which in the same locality aecia had also been found the following spring, and Decodon verticillatus, with infection only on Chenopodium album, which was abundant.

The mid-west collections were made, one by Rev. J. M. Bates, at Red Cloud, Neb., and the other by Mr. R. E. Stone, at Lincoln, Neb. These were sown on Chenopodium album, C. hybridum, Sarcobatus vermiculatus, Monolepis Nuttalliana and Cardamine bulbosa, with infection only on the first-named species.

The far-west collections were made by Prof. P. B. Kennedy, at Reno, Nev. They were sown on Chenopodium album, Atriplex hastata and Sarcobatus vermiculatus, at three different dates, fourteen sowings being made. Abundant infection resulted for all the hosts; nine plants giving equally vigorous results, the other five not thriving well.

These results taken with those of 1906 and 1907 show that no marked biological differences exist. The only indication of restricted adaptation is the failure to infect Sarcobatus from Nevada with teliospores from Nebraska, although, as predicted

${ }^{10}$ Jour. Myc. 13: 197. 1907, and 14: 15. 1908. 
two years ago, ${ }^{17}$ there is no difficulty in producing infection on Sarcobatus from Nevada with teliospores from the same region. ${ }^{18}$

8. Puccinia Seymouriana Arth., on Spartina cynosuroides Willd., collected at Lima, Ind., by Mr. George L. Potter, was sown May 28 on Cephalanthus occidentalis L., giving rise to numerous pycnia June 6 , and aecia June $15 \cdot{ }^{19}$

9. Puccinia fraxinata (Schw.) Arth., collected at Lewes, Del., by Mr. H. S. Jackson, on Spartina polystachya Willd,, was sown April 25 on Adelia ligustrina, Ligustrum vulgare and Fraxinus lanceolata, with infection only on the last-named species. Again on May 2 it was sown on F. lanceolata, giving very abundant pycnia May I3, and aecia June 2.

Another collection from the same locality, but on Spartina stricta Roth, was sown on Smilax hispida and Fraxinus lanceolata, with infection on the last species only.

Collections of aecia, which morphologically are identical with those of Fraxinus, have been made on Ligustrum vulgare in New York, and Adelia segregata in Florida. In 1904 and 1905 attempts were made to grow aecia on plants of these genera, but without success. As the telia came from the western plains, it was thought that telia from the Atlantic sea coast might show less restricted adaptation. So far we are unable to detect any difference in behavior between the rust of the salt marshes of the coast and that of the prairies of the west. It yet remains to try telia from the south along the gulf coast. ${ }^{20}$

io. Puccinia tomipara Trel., on Bromus purgans L., collected at Scotia, Neb., by Rev. J. M. Bates, was sown on Clematis virginiana L. and Thalictrum dioicum L., May 29, giving pycnia on the first-named host only June 7 , and aecia June 16 , both in abundance. ${ }^{21}$

ii. Puccinia asperifolit (Pers.) Wettst., on Secale cereale L., collected by Mr. A. G. Johnson at Lafayette, Ind., July 2I,

${ }^{17}$ Jour. Myc. 13: 198. 1907.

${ }^{18}$ For previous cultures see Bot. Gaz. 35: 19. I903; Jour. Myc. II: 54. I905; 12: 16. 1906; 13: 197. I907; and 14: 15. 1908.

${ }^{10}$ For previous cultures see Jour. Myc. 12: 24. 1906.

${ }^{20}$ For previous cultures see Bot. Gaz. 29: 275. I900; Jour. Myc. II: 57. I905; 12: I6. I906; and 14: I4. 1908.

${ }^{21}$ For previous cultures see Jour. Myc. II: 62. 1905; and 13: 197. I907. 


\section{ARThur: CUltures of UREDiNeAe in $1908 \mathbf{1} 8 \mathbf{8}$}

I908, was sown July 22, on Lycopsis arvensis L. On July 3 I a few pycnia appeared, but owing to the imperfect growth of the leaf no aecia followed.

This rust has usually gone under the collective name of $P$. rubigo-vera (DC.) Wint., which has been applied to most subepiđermal grass rusts not having strongly marked morphological characters. The similar leaf-rust of wheat is clearly a distinct species, judging from the failure of European investigators to make it infect $L y c o p s i s$, from some morphological differences, and from its different period for germination. Teliospores of the leaf-rust from both wheat and rye were tested in the laboratory at the same time by means of drop cultures, and while the rye rust grew readily, the wheat rust showed no germination.

This unequivocal, although scanty result, the first culture of the kind to be made with American material, sets at rest any doubt regarding the identity of the American and foreign leaf-rust on rye. The writer is indebted to the kindness of Dr. P. Magnus, of Berlin, Germany, and Dr. H. O. Juel, of Upsala, Sweden, for seeds of Lycopsis from which plants were grown for the culture work.

I2. Uromyces Scirpi (Cast.) Burr., on Scirpus fluviatilis (Torr.) A. Gray, collected by the writer at Spirit Lake, Iowa, was sown on Cicuta maculata April 6, and gave rise to pycnia April I4, and aecia April 23, both in abundance.

I3. Uromyces houstoniatus (Schw.) Sheldon. In the spring of 1906 Dr. J. L. Sheldon observed a rust appearing on plants of Sisyrinchium gramineum Curtis (S. graminoides Bickn.), growing in contact with plants of Houstonia caerulea bearing Aecidium houstoniatum Schw. The rust on Sisyrinchium proved to be Uromyces Murrillii Ricker, until then only once collected, at the type locality in Maine. Dr. Sheldon has since made further studies in the field, and also convincing inoculations, ${ }^{23}$ and at the same time supplied ample material for repeating his results. The methods used for other species, however, have not proved available for this one, whose teliospores do not enter a resting condition, but germinate in the sorus as soon as mature. It is the only

${ }^{22}$ For previous cultures see Jour. Myc. 13: 199. 1907; and 14: 17. 1908.

23 Torreya 6: 249. 1906; and 9: 54. 1909. 
heteroecious rust known to the writer, having all spore forms and yet leptopuccineous. Plants of Sisyrinchium bearing the rust, sent by Dr. Sheldon in 1906, flourished well in the greenhouse, but the rust gradually disappeared during the following winter. The experience was repeated in 1907. In both cases by March or April the rust had died out and did not again appear, although the plants produced fresh leaves and flourished throughout the winter months and the whole year.

Living plants of Houstonia caerulea bearing aecia, sent by Dr. Sheldon from Morgantown, W. Va., May 3, were potted intermixed with plants of Sisyrinchium gramineum. On June 8 a few uredinia were observed, but did not multiply. On May I8 similar plants were sent by Mr. H. S. Jackson from Newark, Del. These were put into small pots, and on May 23 arranged over plants of Sisyrinchium under a belljar, where they remained three days. On June 7 a great abundance of uredinia was observed, and on July 22 telia also in abundance. As both urediniospores and teliospores are pale and inconspicuous, they doubtless appeared earlier than the record shows.

14. Gymnosporangium Juniperi-Virginianae Schw., on Juniperus virginiana L., was collected by Mr. F. D. Kern and the writer at Mammoth Cave, Ky., in two rather unusual forms. One form had very large galls, very irregular and much divided. The other had very small galls, with one to three telia each, the extruded part of the telia being noticeably fusiform. Both of these forms appeared so different from the forms usually collected farther north, that it seemed possible they might be specifically distinct.

The large form was sown April 13 on Malus Malus (L.) Britt., $M$. coronaria (L.) Mill. and Crataegus punctata Jacq. On $M$. Malus pycnia appeared April 23, but the infection was so pronounced that the leaves were distorted and injured to an extent that precluded the formation of aecia, the leaves gradually dropping until September 26, when two, the only ones still remaining, were removed for the herbarium. On $M$. coronaria abundant pycnia appeared April 2I, followed duly by aecia of characteristic appearance. The Crataegus remained free from infection.

The small form was sown April I3 on Malus coronaria and 


\section{Arthur: Cultures of URedineae in igo 130}

Crataegus punctata, giving a few pycnia on the first, not noticed until May 4, and abundant pycnia on the last, showing April 21. Both hosts matured characteristic aecia by the latter part of June. ${ }^{24}$

i5. Gymnosporangium globosum Farl., on Juniperus virginiana L., collected by Mr. A. B. Seymour at Manchester, Mass., was sown April 29 on Malus Malus, producing no infection, and on Crataegus Pringlei Sarg. (seedling from tree determined by Mr. W. W. Eggleston), giving abundant pycnia, and followed by equally abundant aecia. Another collection made by Mr. F. D. Kern and the writer at Mammoth Cave, Ky., was sown April 13, on Crataegus sp., giving pycnia April 25, but nothing further, due to the death of the host. ${ }^{25}$

i6. Gymnosporangium clavipes C. \& P., on Juniperus virginiana L., collected at Mammoth Cave, Ky., by Mr. F. D. Kern and the writer, was sown on two plants of Crataegus sp., April I3, and gave pycnia on April 25, followed by aecia by the middle of June. A sowing two days later on Aronia nigra gave no infection.

Another collection on the same host, made by Dr. G. P. Clinton at New Haven, Conn., was sown May 2 on Amelanchier erecta with no infection, and on Crataegus sp., giving a few pycnia, but the early maturity of the leaves checked further development. ${ }^{20}$

17. Gymnosporangium clavariaeforme (Jacq.) DC., on Juniperus Sibirica Burgsd., collected by Mr. E. Bethel at Eldorado Springs, Colo., was sown April 28 on the leaves, petioles and stems of Amelanchier erecta Blanch., giving pycnia May 5, and aecia May 23, both in great abundance. ${ }^{27}$

i8. Gymnosporangium Nelsoni Arth., on Juniperus scopulorum Sarg., collected by Mr. E. Bethel at Eldorado Springs, Colo., was sown May 2 on Amelanchier erecta and Sorbus americana, both showing abundance of pycnia May Io. On the first host no further development took place, as the plant was not vig-

${ }^{24}$ For previous cultures see Jour. Myc. 12: 13. 1906; 13: 200. 1907; and 14: 17.1908.

${ }^{25}$ For previous cultures see Jour. Myc. 13: 200. 1907; 14: 18. 1908.

${ }^{20}$ For previous cultures see Jour. Myc. 14: 18. 1908.

${ }^{27}$ For previous cultures see Jour. Myc. 14: 19. 1908. 
orous. On the second host abundant and characteristic aecia were formed. ${ }^{2 s}$

19. Gymnosporangium Betheli Kern, on Juniperus scopulorum, collected by Mr. E. Bethel at Eldorado Springs, Colo., was sown May II, on Pyrus communis, with no infection, and on Sorbus americana, and Crataegus sp., both giving numerous pycnia, on the former host showing May I9, and on the latter not seen until May 3I, although probably appearing earlier. The pycnia in both cases were followed by an abundance of characteristic aecia, well formed by July $7 \cdot{ }^{20}$

20. Gymnosporangium Botryapites (Schw.) Kern, on Chamaecyparis thyoides (L.) B.S.P., collected by Mr. H. S. Jackson at Newfield, N. J., was sown on Amelanchier intermedia Spach, May I8, giving an abundance of pycnia May 28. Although galls followed the pycnia, no aecia were formed owing to the early maturity of the leaves. This is the Gym. biseptatum Ellis. The rather extended synonomy is given by Kern. ${ }^{30}$ Inconclusive cultures of this species were made by Dr. W. G. Farlow in 1877 and I883. In 1886 Dr. Roland Thaxter ${ }^{31}$ made cultures, and raised both pycnia and aecia, repeating his work at a later date.

21. Gymnosporangium cornutum (Pers.) nom. nov. Telia on the branches of Juniperus Sibirica Burgsd. were collected May 19, I908, by Mr. F. D. Kern and Mr. E. Bethel, at Palmer Lake, Colo., and sown May 23 on Sorbus americana, giving an abundance of pycnia June I, followed by numerous aecia. A second sowing was made on another plant of the same host May 25, with equally successful results, the pycnia showing June 5 . In both cases the aecia were mature by August 10. A sowing May 25 on Malus Malus gave no infection.

Although the horn-like aecia of this species are common and often collected, this is the first time that the telia have been found in America. The telia occur on the bark of the small branches, and not at all or only rarely on the leaves. In Europe cultures of this species were made by Oersted, of Denmark, in 1866, and an account with excellent illustrations of both aecia and telia was

${ }^{28}$ For previous cultures see Jour. Myc. 13: 203. I907; and 14: 18. 1908.

29 For previous cultures see Jour. Myc. 14: 23. 1908.

a Bull. Torrey Club 35: 506. I908.

"Proc. Am. Acad. 22: 263. 1887. 


\section{Arthur: Cultures of Uredineae in 1908 241}

published the same year. ${ }^{32}$ Cultures have also been made since, but most investigators in the discussion of their results have confused this with other species.

The form which has been most persistently confused in the telial stage with the present species is what in Europe has been called G. tremelloides Hartig, which has much larger and otherwise different telia on the bark of the larger branches of the same species of juniper, but whose aecia are the true Roestelia penicillata, and although occurring on Sorbus, are easily distinguished by being fimbriate instead of horn-like. Mr. Kern ${ }^{38}$ has recently shown from partly circumstantial evidence that this species is the Tremella juniperina L., and should be called G. juniperinum (L.) Mart. This disposition of the name, G. juniperinum, appears to leave no available name under Gymnosporangium for the present species, and a new combination is therefore necessary. The earliest specific name is that given by Persoon to the aecial form in I79I, Aecidium cornutum, the first species listed under the newly established genus Aecidium.

The other form included by European investigators with the present species has very small telia on the leaves of the same juniper, and horn-like aecia on Aronia. This is discussed in the following paragraphs under the name G. Davisii Kern.

22. Gymnosporangium Davisir Kern. It is with more than usual satisfaction that I report the successful culture of this rust, as it completes a knowledge of the life cycle of a trio of species known to some extent in both Europe and America for many decades, but much confused and misunderstood. The telia occur on the leaves of Juniperus Sibirica, and have been sent in previous years by Dr. J. J. Davis, from Wind Lake near Racine, Wis., but could not be made to germinate. A collection made in the same locality on May 24, 1908, by Dr. J. J. Davis and Mr. F. D. Kern, was sown May 25 on Aronia nigra, Amelanchier erecta and Sorbus americana, with infection only on the Aronia, which showed pycnia June 12, and well matured aecia Sept. I7. Another sowing was made May 25 on Aronia nigra, producing a few pycnia

Overs. Danske Vid. Selsk. Forh. 1866: 185-196. pl. 3, 4, with full abstract in Bull. Soc. Roy. Dan. Sci. 1866: $15-16$.

Science 27: 931, 1908. 
June 15 , but did not further develop owing to weakness of the host.

The aecia of this species have the same horn-like appearance as those of $G$. cornutum, already discussed, and the two are usually included under the same name. The only culture known to the writer, showing that the form on Sorbus and the similar one on Aronia are distinct, was made by Dr. Ed. Fischer ${ }^{84}$ of Bern, Switzerland, and published in November, 1907. On May 29 of that year he made a sowing of teliospores from Juniperus communis on Sorbus Aria, S. torminalis, S. hybrida, S. Aucuparia, Amelanchier Botryapium and Aronia rotundifolia (Amelanchier vulgaris), and obtained an infection only on Aronia. He concluded from this result that the form on Aronia is distinct from that on Sorbus, but made no suggestion regarding the nomenclature. Mr. Kern,$^{85}$ however, finds diagnostic characters to separate the forms in both aecia and telia, and has supplied a name. The cultures by Dr. Fischer were not known to the writer until long after the above studies had been concluded.

23. Melampsora Medusae Thüm., on Populus tremuloides Michx., collected at Boulder, Colo., by Mr. E. Bethel, was sown April 7 on Ribes rubrum, R. Cynosbati and Larix laricina. The only infection was on the Larix, showing pycnia April I4, and aecia April 2I. ${ }^{38}$ When the sowing was made, it was supposed that the rust in hand was Melampsora albertensis Arth.; but after the result was obtained a careful inspection of the remaining material of the collection brought to light the fact that while the leaves were conspicuously covered with that rust, they also bore some sori of the more common species, and it is believed that the infection came from the latter, as recorded above.

SUCCESSFUl CUltURES REPORTED NOW FOR THE FIRST TIME:The following species have never been cultivated, in America or elsewhere, so far as the writer knows. Much credit for the ample results is due to the mycologists who have coöperated in the work by making invaluable observations in the field and supplying suit-

${ }^{34}$ Archiv Sci. Phys, et'Nat. 24: - Nov. 1907.

${ }^{a s}$ Bull. Torrey Club 35: 507. I908.

${ }^{36}$ For previous cultures see Jour. Myc. 10: 13. I904; II: 52. 1905; and I2: 13. 1906. 
Artiur: Cultures of Uredineae in $1908 \%$

able culture material with which to test their suggestions. The segregation of three additional species of western grass rusts of the type of Puccinia rubigo-vera is especially gratifying.

r. Puccinia Absinthin DC., on Artemisia dracunculoides Pursh, collected March I4, I908, at Boulder, Colo., was sown on a plant of the same host species April 9. Another collection on the same host, collected March 24, I908, at Spirit Lake, Iowa, by the writer, was similarly sown April 8. Both sowings gave rise to numerous pycnia first observed April 25, but doubtless appearing fully a week sooner, and were followed by abundant uredinia April 27. Owing to the early maturity of the leaves, no telia were produced in either case.

The results demonstrate that this rust has no aecial stage in its life cycle. As no pycnia in connection with the uredinia had been recorded for the species, either in America or Europe, and as aecia on various species of Artemisia are often collected in America, the status of the species had heretofore been most uncertain. The situation was changed, but still unsettled, by the production of aecia on Artemisia dracunculoides in the cultures of last year, ${ }^{37}$ which were grown from telia on Carex stenophylla. The present cultures very satisfactorily complete our knowledge of the two most common rusts on Artemisia.

2. Pućcinia on Carex comosa Boott, collected at Lewes, Del., Nov. I5, 1907, by Mr. H. S. Jackson (no. 1858), was sown April 25, on Ir'a frutescens, Urtica gracilis, and Smilax hispida, with no infection, the Smilax leaves, however, having died before infection could have shown. Another sowing was made May 22 on the same hosts, and also on Myrica cerifera and Ambrosia trifida. There was no infection except in the case of Smilax, on which pycnia were noticed June 8 , although they might have appeared sooner, and were followed by aecia June 24 .

The clues to this connection of telia and aecia were slight. In reference to his collection Mr. Jackson wrote that "in the locality from which the specimen came was a vine of Smilax rotundifolia with aecia," but he laid little stress on this association, and did not even retain a specimen of the Smilax rust. Upon visiting the locality again in April no Smilar aecia could be found, doubt-

${ }^{27}$ See Jour. Myc. 14: 2r. 1908. 


\section{6:}

less because too early in the season. Some additional probability of the connection, however, was secured from a microscopic examination. The urediniospores of the Carex rust proved to be remarkably large, while the aeciospores on Smilax, belonging to Aecidium macrosporum Peck, are also unusually large, as the name indicates. But on the other hand the western Smilax aecia belong to a grass rust, and most Carex rusts have aecia on composite hosts. It is, therefore, more than usually gratifying to complete the life cycle of this heretofore undetected Carex rust. It is probably a more widely distributed species than shown by the range of the present known aecial collections, all of which are eastern, except one from Kansas.

Puccinia macrospora (Peck) nom. nov.

(Aecidium macrosporum Peck, 23rd Rep. N. Y. St. Mus. 6r. 1873.)

O. Pycnia epiphyllous, few in groups on slightly discolored spots, not conspicuous, subepidermal, in vertical section flattenedgloboid, $128-160 \mu$ in diameter by $80-100 \mu$ high.

I. Aecia hypophyllous, chiefly in annular groups $1.5-5 \mathrm{~mm}$. across, rather short, $0.1-0.2 \mathrm{~mm}$. in diameter; peridial cells linearrhomboidal, $32-42 \mu$ long, outer wall thin, smooth, inner wall somewhat thicker, moderately verrucose; aeciospores globoid, very large, $32-42$ by $37-5 \mathrm{I} \mu$, wall colorless, medium thick; I. $5-2.5 \mu$, thicker above, $5^{-10} \mu$, rather coarsely verrucose.

On Smilax hispida Muhl., Long Branch, N. J., July, I87o, G. W. Clinton; Manhattan, Kans., June 25, I886, W. A. Kellerman; $S$. rotundifolia L., Riverhead, Suffolk Co., N. Y., I869, Charles H. Peck (type) ; Brown's Mills, N. J., June 26, I889, B. Halsted; Seaford, Del., July 9, I907, H. S. Jackson; Lewes, Del., June 6, I908, M. T. Cook \& H. S. Jackson.

II. Uredinia amphigenous, scattered or in longitudinal series, oblong, $0.5^{-1} \mathrm{~mm}$. long, tardily dehiscent; urediniospores obovate or narrowly ellipsoid, rather irregular, very large, $26-37$ by $40-$ $60 \mu$, often narrowed below to a thickened hilum; wall golden yellow, evenly thick, 2.5-3.5 $\mu$, echinulate with prominent points 3 $4 \mu$ apart; pores obscure, 2 or sometimes 3 , equatorial.

III. Telia chiefly hypophyllous, scattered or in longitudinal series, oblong or linear, $0.5-1.5 \mu$ long, finally naked, pulvinate, chocolate-brown, ruptured epidermis noticeable; teliospores clavate, $16-23$ by $6 \mathrm{I}-67 \mu$, usually rounded or obtuse above, narrowed below, usually slightly constricted at the septum; wall pale 
Arthur: Cultures of Uredineae in igo $136_{245}$ cinnamon-brown, paler below, medium thin, I. $5-2.5 \mu$, much thicker

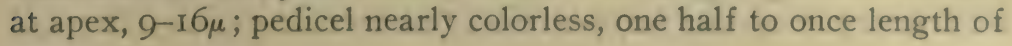
spore.

On Carex comosa Boott, Lewes, Del., Nov. I5, Ig07, H. S. Jackson 1858 .

3. Puccinia on Carex pratensis Drej. An observation by Mr. E. Bethel at Tolland, Colo., July 25, I907, when aecia on Agoscris were found in very close proximity to rusted Carex pratensis, led to a collection of telial material from the same spot in October following, and a successful culture. The teliospores were sown May I3, on a plant of Agoseris glauca, raised from seed previously sent by Mr. Bethel, and pycnia began to show May I9 in the greatest abundance. The infection was so heavy that the plant was killed before aecia were formed.

A study of all available data regarding this species has led to the conclusion that a very large part of all collections of aecia on the various species of Agoseris belong to this species, and not as sometimes assumed to Puccinia Troximontis Peck, which is common on the same hosts, but probably has no aecial stage. A description of the species is appended, but no attempt will be made at this time to cite the numerous known localities or to map out the range, which doubtless embraces much of the western mountainous region.

\section{Puccinia patruelis sp. nov.}

O. Pycnia amphigenous, rather few, in groups $0.5^{-1} \mathrm{~mm}$. across, punctiform, inconspicuous, honey-yellow becoming brownish, subepidermal, in vertical section globoid, 96-125 $\mu$ in diameter by $80-100 \mu$ high; ostiolar filaments $30-55 \mu$ long.

I. Aecia amphigenous, numerous in crowded groups $\mathrm{I}-4 \mathrm{~mm}$. across, often surrounding groups of pycnia; peridium colorless, rather short, margin finely lacerate; peridial cells rhomboidal, I $8-25 \mu$ long, outer wall rather thick, $3-4 \mu$, striate, smooth, inner quite thin, finely verrucose; aeciospores mostly globoid, I3-16 by I6-2I $\mu$; wall colorless, thin, I $\mu$, very finely verrucose, appearing smooth when wet.

On Agoseris glauca (Pursh) Greene (Troximon glaucum Pursh), Tolland, Colo., July 25, I907, E. Bethel.

II. Uredinia chiefly hypophyllous, scattered, oblong or oval, 0.4-0.6 mm. long, rather tardily naked, cinnamon-brown; urediniospores ellipsoid or obovate-ellipsoid, I3-I9 by I9-26 $\mu$; wall golden-brown, moderately echinulate, pores 2 , lateral and opposite, slightly superequatorial. 
III. Telia hypophyllous, scattered, numerous, oval or oblong, 0.3-0.8 mm. long, early naked, dark blackish-brown, conspicuous, ruptured epidermis noticeable; teliospores broadly clavate or spatulate, $15-23$ by $32-63 \mu$, apex rounded or obtuse, base usually narrowed, slightly constricted at the septum; wall dark chestnutbrown, paler below, moderately thin, $1.5-2 \mu$, thicker at apex $7^{-1} 3 \mu$; pedicel slightly colored next the spore, somewhat shorter than the spore.

On Carex pratensis Drej., Tolland, Colo., July 25 and Oct. I9, I907, E. Bethel (type).

4. Puccinia cinerea Arth., on Puccinellia airoides (Nutt.) Wats. \& Coult., collected at Arvada, Colo., by Mr. E. Bethel, was sown April 22 on Oxygraphis Cymbalaria (Pursh) Prantl (Ranunculus Cymbalaria Pursh), giving rise to pycnia April 30, and aecia May 4. A duplicate sowing was made May 7, and pycnia followed May 14, with aecia May I9. In each case the sori were produced in abundance.

The clue for this combination was obtained by Rev. J. M. Bates, who had found the same species of rust on Poa growing in proximity to rusted Oxygraphis in a number of places in Nebraska under conditions which seemed to make their genetic connection almost certain. ${ }^{88}$ Unfortunately the culture material sent by him both this year and previously failed to germinate. The plants of Orygraphis used for the cultures were supplied by him. The Colorado material was received unnamed, and from its general appearance was supposed to be on some species of Poa, until after the work was completed when the determination was made by Mrs. Agnes Chase of the agrostological division of the National Herbarium.

5. Puccinia on Koeleria cristata. A number of collections of this rust were sent by $\mathrm{Mr}$. E . Bethel, who made the suggestion several times that it was probably connected with aecia on Mahonia, a suggestion that seemed to us unimportant, as the aecia on Mahonia in Europe are known to belong to Puccinia poculiformis, a cosmopolitan rust wholly unlike the one on Koeleria. As a collection made by Mr. Bethel April 25, 1908, at Plainview, Colo., showed germination, and as he had written that "the rust on Koeleria undoubtedly belongs to the aecia on Mahonia, for I have

${ }^{\approx}$ See Bull. Torrey Club 34: 584. 1907. 
Arthur: Cultures of L'redineae in igos $38_{247}$

found hundreds of cases to substantiate it-I wish you would try it," a sowing was accordingly made April 30 on Mahonia Aquifolium. Abundance of pycnia appeared May I4, and aecia May 24. Another sowing was made June 2 on Berberis vulgaris, but gave no infection.

Upon examination of the available collections of aecia on $\mathrm{Ma}$ honia, which had not been given careful study before, it was discovered that they differed in a characteristic way from those on Berberis. They are smaller, do not produce a thickening of the leaf, and cause a rounded area of the leaf on which each group is seated to die early, turning brown and dry. From our inquiry it seems probable that no aecia on Mahonia belonging to Puccinia poculiformis have yet been found in America, although they have been so cited, but that they all should go under the present species, a description of which follows.

\section{Puccinia Koeleriae sp. nov.}

O. Pycnia chiefly epiphyllous, numerous, rather loosely arranged in groups $0.5^{-2} \mathrm{~mm}$. across, on discolored spots, punctiform, not conspicuous, subepidermal, honey-yellow becoming blackish, in vertical section lenticular, $80-100 \mu$ in diameter by $45-65 \mu$ high.

I. Aecia hypophyllous, numerous, usually crowded in groups I-3 $\mathrm{mm}$. or more across, on discolored spots $\mathrm{I}-7 \mathrm{~mm}$. across, which finally die and turn blackish-brown, short cylindrical, 0.4$0.7 \mathrm{~mm}$. high by $0.1-0.2 \mathrm{~mm}$. in diameter; peridium colorless, cells rhomboidal in radial section, outer wall rather thick, $5-7 \mu$, transversely striate, inner wall medium thin, $I-3 \mu$, verrucose; aeciospores globoid, $13-20$ by $18-26 \mu$, wall colorless, rather thin, I-I.5 $\mu$, evenly and finely verrucose.

On Mahonia Aquifolium (Pursh) Nutt. (Berberis Aquifolium Pursh, B. repens Lindl.), Ouray, Colo., July 26, 1897, C. L. Shear, July 2, 1907, E. Bethel; Victor, Idaho, July Io, I901, E. D. Merrill \& E. N. Wilcox; Wild Horse Island, Mont., Aug. I3, I908, M. E. Jones 7718; Yellow Bay, Mont., Aug. Io, I908, M. E. Jones 7723.

II. Uredinia amphigenous, in groups on discolored spots, oblong or linear, $0.1-0.2 \mathrm{~mm}$. wide by $0.5-1.5 \mathrm{~mm}$. long, soon naked, pulverulent, cinnamon-brown, ruptured epidermis conspicuous; paraphyses numerous, capitate or clavate-capitate, IO-16 by $42-65 \mu$; urediniospores broadly ellipsoid, $19-26$ by $23-34 \mu$; wall cinnamonbrown, medium thick, $2-2.5 \mu$, rather closely echinulate-verrucose; pores $4-6$, scattered.

III. Telia hypophyllous, scattered, oblong or linear, about O.I 
$\mathrm{mm}$. wide by $0.5^{-\mathrm{I}} .5 \mathrm{~mm}$. long, sometimes confluent, long covered by the epidermis, grayish-black; teliospores clavate or oblongclavate, I $5-2 \mathrm{I}$ by $45^{-55 \mu}$, obtuse or truncate above, narrowed below; wall chestnut-brown, paler beneath, thin, about $\mathrm{I} \mu$, thicker at apex, $3-5 \mu$, smooth; pedicel short, slightly colored.

On Koeleria cristata (L.) Pers., Ouray, Colo., Aug. 23, 1907, E. Bethel (type); Boulder, July 31, I905, Plainview, Aug. 5, 1905, and April 25, 1908, Marshall, June 24, I905, Golden, July 27, I908, all in Colo., E. Bethel.

6. Puccinia on Bromus. A subepidermal rust on various species of Bromus is common in the western mountains. Collections made by Prof. E. W. D. Holway, Sept. 4 and 7,1907 , on $B$. Pumpellianus Scribn., at Banff, Alb., were found close to Thalictrum bearing aecia, and believed by him to be connected, but the teliospores could not be brought to germination. A collection on B. Porteri (Coult.) Nash, made by Mr. F. D. Kern, Sept. 2, I908, at Ouray, Colo., with much more definite and certain field clues, being intermixed with Thalictrum sparsiflorum bearing aecia, was found more tractable and was sown April 30, on Thalictrum dioicum, giving rise to pycnia May 9, and aecia May 30, both in abundance.

It has long been recognized that the aecia on Thalictrum in America belong to a number of species. No cultures, however, have been made heretofore, and only the form associated with Tranzschelia punctata (Puccinia Pruni-spinosae), common in the eastern part of the country, has been definitely placed. In Europe cultures have shown aecial forms on Thalictrum to belong to telia on Agrostis, Poa, Triticum, Elymus and Polygonum. Whether any of these occur in America, remains to be determined, although the last two are to be expected. The species in hand appears to be unrecorded, and a description is therefore appended. It is closely related, both morphologically and in its hosts, with $P$. tomipara Trel., which ranges throughout the central and eastern states with its aecia on Clematis and telia on Bromus. The question of their exact relationship must be left to future investigation.

\section{Puccinia alternans sp. nov.}

O. Pycnia epiphyllous, crowded in groups $0.5-4 \mathrm{~mm}$. across, not conspicuous, subepidermal, in vertical section globoid, $60-96 \mu$ in diameter, $50-80 \mu$ high. 


\section{Arthur: Cultures of Uredineae in ido 100 , 140}

I. Aecia chiefly hypophyllous, in annular or often crowded groups I.5-5 mm. across, cylindrical, $0.4-0.8 \mathrm{~mm}$. high; peridium colorless, margin slightly recurved, finely lacerate, cells rhombic in longitudinal section, $2 \mathrm{I}-29 \mu$ long, walls transversely striate, outer thick, $9-12 \mu$, inner somewhat thinner, $5-7 \mu$, finely verrucose; aeciospores globoid or broadly ellipsoid, $15-20$ by $17-24 \mu$, wall colorless, thin, I-I.5 $\mu$, finely and evenly verrucose.

On Thalictrum Fendleri Engelm., Gunnison Co., Colo., Sept. 2, I899, E. Bartholomew; Salt Lake Co., Utah, July 12, I904, A. O. Garrett (Sydow, Ured. 1935; Vestergren, Micr. rar. sel. I002; and Garrett, Fungi Utah. 76); T. occidentale A. Gray, Victor, Idaho, July II, I90I, E. D. Merrill \& E. N. Wilcox I256; Banff, Alberta, July 24, 1901, and July 6, 1907, E. W. D. Holzeay; T. sparsiflorum Turcz., Ouray, Colo., Sept. 2, I907, F. D. Kern; Minnehaha, Colo., Aug. I3, I906, F. E. Clements; T. venulosum Trel., Spicer, Routt Co., Colo., July, I903, L. N. Goodding; Macdougal Park, Mont., July 31, 1908, M. E. Jones.

II. Uredinia amphigenous, scattered, oblong or linear-oblong, $0.2-0.8 \mathrm{~mm}$. long, rather early naked, somewhat pulverulent, cinnamon-brown, ruptured epidermis conspicuous; urediniospores very broadly ellipsoid or slightly obovate-ellipsoid, 19-25 by $23-29 \mu$; wall light cinnamon-brown, moderately thick, $2-2.5 \mu$, finely echinulate; pores about 6 , scattered.

III. Telia amphigenous, scattered, oblong or linear-oblong, $0.4-1 \mathrm{~mm}$. long by $0.2-0.4 \mathrm{~mm}$. wide, long covered by the epidermis, dark blackish-brown; teliospores clavate or clavate-oblong, 13-19 by 3I-6I $\mu$, usually truncate or obtuse above, narrowed below, slightly or not constricted at the septum; wall chestnutbrown, paler below, rather thin, I-I.5 $\mu$, thicker at apex, $3-5 \mu$, smooth; pedicel somewhat colored, very short.

On Bromus Porteri (Coult.) Nash, Ouray, Colo., Sept. 2, I907, F. D. Kern (type); Parley's Canyon, Utah, Aug. I8, I908, A. O. Garrett II37; B. Pumpellianus Scribn., Banff, Alberta, Sept. 4 and 7 , 1907, E. W. D. Holway; B. Richardsoni Link, Ouray, Colo., Aug. 23, 1907, E. Bethel.

7. Puccinia on Agropyron. Two collections of rusted Agropyron biflorum, collected Sept. 2, 1907, at Lake Louise, in the Canadian Selkirks, were sent by Prof. E. W. D. Holway, with the suggestion that one of them be sown on Thalictrum and the other on Aquilegia. One collection failed to germinate, the other was sown April 18 on Aquilegia canadensis and Thalictrum dioicum, with infection only on the first, the leaves of which soon began to show hypertrophy of the tissues, and in six to seven days small yellow, 
translucent spots above, followed on May 8 by aecia beneath. No pycnia were formed, as sections and microscopic examination fully proved. All American collections of aecia on Aquilegia in the herbarium were found to have either no pycnia associated with the groups of aecia, or more rarely only a few pycnia, a condition not before noted in heteroecious rusts of grasses and sedges.

This rust is undoubtedly quite well distributed in the western mountains, and embraces a large part of all aecia yet found in America on Aquilegia. It is apparently distinct from Puccinia Agrostidis Plowr., a European species with aecia on Aquilegia, and is, therefore, described as new, although there is much morphological similarity between the two.

\section{Puccinia obliterata sp. nov.}

O. Pycnia few, frequently obsolete, epiphyllous, gregarious, inconspicuous, honey-yellow, in vertical section globoid, 80-107 $\mu$ in diameter; ostiolar filaments $40-75 \mu$ long.

I. Aecia chiefly hypophyllous, thickly crowded in groups I-5 $\mathrm{mm}$. across, on slightly larger discolored spots, rather short; peridium colorless, margin somewhat erose, cells rhomboidal in longitudinal section, $16-24 \mu$ in length; aeciospores globoid, or often somewhat angular, $15^{-19}$ by $18-25 \mu$, wall colorless, thin, about $\mathrm{I} \mu$, very minutely verrucose, appearing nearly smooth when wet.

On Aquilegia caerulea James, Buffalo Pass, Park Range, Colo., Aug. I3, 1898, C. L. Shear \& E. A. Bessey (Ellis \& Ev., Fungi Columb. I474); Trapper's Lake, Colo., Aug. I4, 1894, Prof. C. S. Crandall I00; Beulah, N. Mex., June 29, 1909, Mrs. W. P. Cockerell; North Vermilion Creek, Sweetwater Co., Wyo., July I7, I897, A. Nelson; A. elegantula Greene, Ouray, Colo., July I2, 1907, F. E. \& E. S. Clements (Crypt. Form. Colorad. 592); A. flavescens Wats., Banff, Alb., July 25, I901, Laggan, Alb., July 2I, I907, E. W. D. Holway; A. formosa Fisch., Skamania Co., Wash., Aug. 12, 1886, W. N. Suksdorf; A. truncata Fisch. \& Mey., Jackson Co., Oreg., July 9, I903, E. B. Copeland (Sydow, Ured. 1767 ).

II. Uredinia chiefly hypophyllous, scattered, linear, small, soon naked, pulverulent, cinnamon-brown, ruptured epidermis noticeable; urediniospores globoid or broadly ellipsoid, I6-23 by I9$29 \mu$; wall light cinnamon-brown, medium thin, I.5-2.5 $\mu$, finely echinulate-verrucose, pores 6-8, scattered.

III. Telia chiefly epiphyllous, scattered, often crowded and con- 


\section{Artiur: Cultures of Uredineae in og $14 \mathcal{L}_{251}$}

fluent, oblong or linear, $0.1-0.3 \mathrm{~mm}$. wide by $0.5^{-2} \mathrm{~mm}$. long, tardily naked, blackish; teliospores clavate or clavate-oblong, 13I9 by $29-5 \mathrm{I} \mu$, obtuse or somewhat rounded above, narrowed below, very slightly or not constricted at the septum; wall dark chestnut-brown, paler below, thin, I-I. $5 \mu$, thicker at apex, $3-5 \mu$. smooth ; pedicel colored, short.

On Agropyron biflorum R. \& S., Lake Louise, Laggan, Alb., Sept. 2, 1907, E. W. D. Holway (type); A. caninum (L.) Beauv., Laggan, Alb., Sept. 2, 1907, E. W. D. Hohway.

8. Puccinia Muhlenbergiae Arth. \& Holw. collected by Mr. E. Bartholomew, March 23, 1908, at Stockton, Kans., on Muhlenbergia glomerata Trin., was sown at different dates on ten different species of host plants, including Hibiscus militaris Cav., with no infection. Another collection with same data, but on $M$. mexicana (L.) Trin., was sown April 22 on Dalea laxiflora with no infection, again May I 5 on same host, and on Ceanothus americanus and Xanthoxylum americanum, still with no infection. A third attempt was made by sowing June 12 , on Baptisia tinctoria, Rudbeckia laciniata and Callirrhoe involucrata. Little culture work is done so late in the season as this last attempt, and it was supposed no infection had been secured, when on July 23 an abundance of aecia, accompanied by a few pycnia, were noticed on the plant of Callirrhoe. Although not under continuous observation, it is believed they came from the sowing.

Many attempts have been made to cultivate the rusts found on various species of Muhlenbergia, ${ }^{39}$ twenty-six species of hosts having been used. The year following the reported success by Prof. W. A. Kellerman ${ }^{40}$ in sowing rust from Muhlenbergia mexicana, collected in Ohio, on Hibiscus Moscheutos, a strong effort was made to repeat his work with material from Kansas and Nebraska, but with no definite result. Mr. E. Bartholomew more than once suggested that the material he supplied was connected with Accidium Napaeae A. \& H., as the results have seemingly shown.

The aecia obtained by Professor Kellerman, and those secured by the writer, are quite unlike. The former are rather large and

30 For record of unsuccessful sowings see Bot. Gaz. 35: II. I903: Jour. Myc. II: 5x. 1905; and 13: 192. 1907.

^0 Jour. Myc. 9: 109, 232. 1903. 
numerous, and bright orange-yellow, the latter are small, fewer and nearly or quite colorless. Upon a careful examination of the telial material used in the two successful trials, it is found that while that from Kansas is the true Puccinia Muhlenbergiae, that from Ohio is $P$. dochmia B. \& C., or at least quite distinct from the other. Considerable more study is needed to fully clear up the relationship of the Muhlenbergia rusts.

9. Gymnosporangium Libocedri (P. Henn.) Kern. For many years the only known locality for the telia of this rust has been in northern California at a place rarely visited by botanists. While Mr. F. D. Kern during January, 1908, was working upon material in the herbarium of Dr. W. G. Farlow at Harvard University, a collection of this rust was seen from Eugene, Ore., made by Dr. A. R. Sweetser, of the University of Oregon. There was also in the herbarium a collection, from the same locality and by the same person, of Aecidium Blasdaleanum D. \& H. on Crataegus. This Aecidium has also been taken by more than one collector from the region of the Libocedrus rust in California. The Crataegus rust is stated by Dr. Dietel, in a note appended to the original description, to be "a true Aecidium, and does not belong to the genus Roestelia comprising the aecidial stages of Gymnosporangium." Recent very careful study confirms Dr. Dietel's statement regarding its morphological resemblances, for in the peridial cells, the spores, and the mode of dehiscence, which provide the chief generic characters, it is wholly unlike the form genus Roestelia.

In order to secure culture material Dr. Sweetser was appealed to. He responded promply with telial collections on Libocedrus decurrens, which came through the mails in perfectly fresh condition. For his efficient aid Dr. Sweetser is entitled to much credit. A sowing was made April I on Crataegus Pringlei and Amelanchier canadensis, giving no infection on the Amelanchier, but on the Crataegus numerous pycnia began to show April 12, followed on April 20 by an abundance of well-formed aecia. Another sowing was made on Crataegus sp. April 4, resulting in such a heavy infection, the pycnia showing April I4, that the leaves were killed before there was time for aecia to form.

The aecia secured by the culture agree perfectly with Aecidium 
Blasdaleanum, being wholly lacking in Roestelial characters. The aberrant form of the aecia is to a certain extent paralleled by the unusual form of the telia, which led Dr. P. Hennings to describe the telial stage as a Phragmidium.

I0. Gymnosporangium sp. nov. The series of circumstances leading to the discovery of telia that made the present cultures possible has been briefly narrated in the introductory paragraphs of this report. On April I0, I908, a collection was made at Mammoth Cave, Ky., by Mr. F. D. Kern and the writer, on the branches of Iuniperus virginiana, and on the following day a growing plant of the same species only six inches high with large sori on the main axis was obtained. The first collection was sown April I3 on Porteranthus stipulatus (Gillenia stipulacea), producing an abundance of pycnia April 2I, but the plant did not thrive, soon dying outright. Another sowing of the same material was made April 15 on Porteranthus and also on Crataegus punctata, with no infection on the latter, but very abundant infection on the former, pycnia showing April 23, and aecia May 25. Another sowing April 16 on Porteranthus gave such a heavy infection, pycnia showing April 23, that the plant was soon killed. Still another sowing April 27, and one April 28, gave vèry abundant pycnia May 5, followed by numerous well-grown aecia that matured May 25 from the first sowing, and May $3 \mathrm{I}$ from the second. The small plant of Juniperus had been potted, and continued to thrive. Teliospores from this living plant were placed on a plant of Porteranthus May II, and on May I7 an abundance of pycnia appeared, followed by numerous aecia that were mature by June 7.

The aecia from the cultures proved to be identical with those collected by Rev. Demetrio in I884, at Perryville, Mo., and issued as No. 3323 in Rabenhorst-Winter, Fungi europaei. They are especially remarkable in the fact that they occur on a non-pomaceous host, an herbaceous perennial, although heretofore the aecia of all species of Gymnosporangium have been supposed to occur exclusively on the ligneous plants of the family Malaceae. With the aecia of this species going outside the Malaceae for its host, and those of the preceding. species falling outside the genus Roestelia, two of the most marked characteristics pertaining to the first stage of the Gymnosporangia are shown to have exceptions. 
Gymnosporangium exterum Arthur \& Kern sp. nov.

O. Pycnia epiphyllous, rather few, very sparsely disposed in definite groups $3-6 \mathrm{~mm}$. across, prominent, subepidermal, in vertical section flattened-globoid, $95-125 \mu$ in diameter by $65-90 \mu$ high ; ostiolar filaments $48-65 \mu$ long.

I. Aecia hypophyllous, very sparsely disposed in large groups 4-10 $\mathrm{mm}$. or more across, on larger discolored areas, 0.I-0.3 mm. in diameter by $0.5-0.8 \mathrm{~mm}$. high; peridium soon becoming rather finely lacerate almost to base, spreading but not revolute, cells usually seen only in face view, IO-1 8 by $58-100 \mu$, inner wall rugose with rather narrow ridges running downward and outward, side walls rugose, $3-5 \mu$ thick; aeciospores broadly ellipsoid or globoid, $17-2 \mathrm{I}$ by $2 \mathrm{I}-26 \mu$; wall very pale cinnamon-brown, medium thick, $2-2.5 \mu$, very finely verrucose, pores evident, 8 -IO, scattered.

On Porteranthus stipulatus (Muhl.) Britton (Gillenia stipulacea Nutt., Spiraea stipulata Muhl.), Perryville, Mo., I884, C. H. Demetrio (Rab.-Wint., Fungi Eur. 3323) ; Mammoth Cave, Ky., June, I87o, T. F. Allen.

III. Telia caulicolous, from a permanent mycelium, appearing on fusiform swellings $2-6 \mathrm{~cm}$. long by $0.5-1.5 \mathrm{~cm}$. or more in diameter, causing a considerable roughening and exfoliation of the bark, flattened, irregular and indefinite in outline, usually anastomosing over practically the whole surface of the swelling, light chocolate-brown becoming yellowish by germination; teliospores ellipsoid, $18-23$ by $32-42 \mu$, rounded or sometimes narrowed above and below; wall light cinnamon-brown, rather thin, I-I. $5 \mu$, usually slightly thicker at apex, pores $I$ in each cell, apical; pedicel cylindrical, uniform, slender, $3^{-4 \mu}$ in diameter, very long.

On Juniperus virginiana L., Mammoth Cave, Ky., April Io, 1908, J. C. Arthur \& F. D. Kern (type).

\section{SumMary}

The following is a complete list of the successful cultures made during the year 1908. It is divided into two series: species that have previously been grown in cultures and reported by the writer or other investigators, and species whose culture is now reported for the first time.

\section{A. Species Previously Reported}

I. Puccinia Kuhniae Schw.-Teliospores on Kuhnia Hitchcockii A. Nels., sown on $K$. eupatorioides $\mathrm{L}$.

2. Puccinia Peckir (DeT.) Kellerm.-Teliospores on Carex stipata Muhl., sown on Onagra biennis (L.) Scop. 
Arthur: Cultures of Uredineae in 1908 \& 146

3. Puccinia Sambuci (Schw.) Arth.-Teliospores on Carex lurida Wahl., sown on Sambucus canadensis L.

4. Puccinia Caricis-Solidaginis Arth.-Teliospores on Carex sparganioides Muhl., sown on Solidago canadensis L.

5. Puccinia Eleocharidis Arth.-Teliospores on Eleocharis palustris (L.) R. \& S., sown on Eupatorium perfoliatum L.

6. Puccinia angustata Peck.-Teliospores on Scirpus cyperinus (L.) Kunth., sown on Lycopus communis Bickn. and $L$. americanus Muhl.

7. Puccinia subnitens Diet.-Teliospores on Distichlis spicata (L.) $)^{\cdot}$ Greene, sown on Chenopodium album L., Atriplex hastata L. and Sarcobatus vermiculatus (Hook.) Torr.

8. Puccinia Seymouriana Arth.-Teliospores on Spartina cynosuroides Willd., sown on Cephalanthus occidentalis L.

9. Puccinia fraxinata (Schw.) Arth.-Teliospores on Spartina polystachya Willd. and on S. stricta Roth, sown on Fraxinus lanceolata Borck.

io. Puccinia tomipara Trel.-Teliospores on Bromus purgans L., sown on Clematis virginiana $\mathrm{L}$.

i i. Puccinia asperifolii (Pers.) Wettst.-Teliospores on Secale cereale L., sown on Lycopsis arvensis L.

12. Uromyces Scirpi (Cast.) Burr.-Teliospores on Scirpus fluviatilis (Torr.) A. Gray, sown on Cicuta maculata L.

I3. Uromyces houstoniatus (Schw.) Sheldon.-Aeciospores on Houstonia caerulea L., sown on Sisyrinchium gramineum Curtis.

14. Gymnosporangium Juniperi-Virginianae Schw.-Teliospores on Juniperus virginiana L., sown on Malus coronaria (L.) Mill., M. Malus (L.) Britt. and Crataegus punctata Jacq.

15. Gymnosporangium globosum Farl.-Teliospores on Juniperus virginiana L., sown on Crataegus Pringlei Sarg.

16. Gymnosporangium clavipes C. \& P.-Teliospores on Juniperus virginiana L., sown on Crataegus sp.

17. Gymnosporangium clavariaeforme (Jacq.) DC.-Teliospores on Juniperus Sibirica Burgsd., sown on Amelanchier erecta Blanch.

18. Gymnosporangium Nelsoni Arth.-Teliospores on Juniperus scopulorum Sarg., sown on Amelanchier erecta Blanch. and Sorbus americana Marsh. 
19. Gymnosporangium Betheli Kern.-Teliospores on Juniperus scopulorum Sarg., sown on Crataegus sp. and Sorbus americana Marsh.

20. Gymnosporangium Botryapites (Schw.) Kern.-Teliospores on Chamaecyparis thyoides (L.) B.S.P., sown on. Amelanchier intermedia Spach.

2I. Gymnosporangium cornutum (Pers.) Arth.-Teliospores on Juniperus Sibirica Burgsd., sown on Sorbus americana Marsh.

22. Gymnosporangium Davisir Kern.-Teliospores on Juniperus Sibirica Burgsd., sown on Aronia nigra (Willd.) Britt.

23. Melampsora Medusae Thüm.-Teliospores on Populus tremuloides Michx., sown on Larix laricina (DuR.) Koch.

B. Species Reported Now for the First Time

I. Puccinia Absinthin DC.-Teliospores on Artemisia dracunculoides Pursh, sown on same host.

2. Puccinia macrospora (Peck) Arth.-Teliospores on Carex comosa Boott, sown on Smilax hispida Muhl.

3. Puccinia patruelis Arth.-Teliospores on Carex pratensis Drej., sown on Agoseris glauca (Pursh) Greene.

4. Puccinia cinerea Arth.-Teliospores on Puccinellia airoides (Nutt.) Wats. \& Coult., sown on Oxygraphis Cymbalaria (Pursh) Prantl.

5. Puccinia Koeleriae Arth.-Teliospores on Koeleria cristata (L.) Pers., sown on Mahonia Aquifolium (Pursh) Nutt.

6. Puccinia alternans Arth.-Teliospores on Bromus Porteri (Coult.) Nash., sown on Thalictrum dioicum L.

7. Puccinia obliterata Arth.-Teliospores on Agropyron biflorum R. \& S., sown on Aquile gia canadensis L.

8. Puccinia Muhlenbergiae Arth. \& Holw.-Teliospores on Muhlenbergia glomerata Trin., sown on Callirrhoe involucrata (T. \& G.) A. Gray.

9. Gymnosporangium Libocedri (P. Henn.) Kern.-Teliospores on Libocedrus decurrens Torr., sown on Crataegus Pringlei Sarg.

io. Gymnosporangium exterum Arth. \& Kern.-Teliospores on Juniperus virginiana L., sown on Porteranthus stipulatus (Muhl.) Britt.

Purdue University,

LAFAYETTE, IND. 


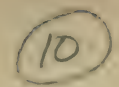

[Reprinted from Mycologia, Vol. II., No. 5, September, rgio.]

148

\section{CULTURES OF UREDINEAE IN $1909^{1}$}

\section{J. C. ARthur}

The year 1909 marks the beginning of the second decade of culture work by the writer. The present report is preceded by nine other similar reports ${ }^{2}$ covering work done between 1899 and 1908 inclusive, each issued annually except the second one, which covered two years. The following account of the work for the year 1909 is divided into a general introductory part, a list of negative results, in which the sowing of the spores did not bring hoped-for infection but the record seemed worth preserving for use in directing future work, and a list of positive results, in which the sowing of spores caused an infection that gave rise to. characteristic fruiting bodies. The successful sowings largely belonged to species previously cultivated, and are recorded to verify or amplify existing knowledge. A small number of successful sowings were made with species never before cultivated, and whose alternate forms had never before been associated.

The work of the year was carried on under adverse and tryingconditions. A new building for the experiment station was begun in the previous autumn, and was located upon the ground where for many years a great variety of plants has been grown, especially brought together for this work. It was in effect a small botanical garden filled with plants from all over the continent known to serve as hosts for different species of rusts, and from which plants were in large part drawn for the cultures. As. many plants as possible were removed to another plot of ground some distance away, but many species were wholly lost. The seedlings of self-sown annuals were especially missed in providing potted plants for the spring's work. The heavy infectional work had only begun in April when it became necessary to. abandon the greenhouses where the work was in progress, so they

\footnotetext{
${ }^{2}$ Read before the Botanical Society of America at the Boston meeting, December 29, 1909.

${ }^{2}$ See Bot. Gaz. 29: 268-276, 35: 10-23; Jour. Myc. $8: 51-56$, 10: 8-21, II : 50-67, 12: II-27, 13: 189-205, 14: 7-26; and Mycol. I : 225-256.
} 
could be wrecked. The temporary quarters provided in another greenhouse were scarcely in working order before another move was necessary. This time a hastily constructed glass lean-to, placed on the east side of a frame building, was made from the wreckage of the two demolished houses. Good conditions for securing infection could not be uniformly maintained. Not only was the practical part of the work hampered in this manner, but the time required in designing the botanical rooms and furnishings for the new experiment station, making temporary adjustments in the old quarters, and finally moving into the new building, seriously interfered with the correspondence and the excursions by which material and information are brought together for making cultures of untried species.

The chief excursion of the year was made by Mr. F. D. Kern and the writer to South Carolina, with incidental stops in Tennessee and North Carolina. It occupied a week during the middle of March. The first stop was at Knoxville, Tenn., where Prof. S. M. Bain, of the University of Tennessee, courteously aided us in every way possible. Upon our return journey we spent a day at Asheville, N. C. At both places culture material was secured. The trip was especially planned, however, to visit the localities made famous to mycologists by the very important contributions of H. W. Ravenel.

Mr. Ravenel belonged to a distinguished southern family, whose estate lay some miles north of Charleston on the Santee Canal, a water way long since fallen into disuse. It was here that he obtained the material for the five centuries of his Fungi Caroliniani Exsiccati, issued during the decade preceding the Civil War. Nearly two days were spent most profitably in this locality. Our work was much facilitated by the intelligent interest of Mr. Octavus Cohen of Monks Corners, the nearest railway town, although not himself a botanist. We were desirous, among other things, to rediscover and identify the uncertain rust from the trunks of cedar trees, issued as no. 87 in the fifth century of the Fungi Caroliniani, under the name Gymnosporangium Juniperi. We were not only able to do this, deciding that it belongs to the multiform species, G. nidus-avis, and not to the one whose name it bears, but in addition we found two hith- 
erto undetected species of the same genus, also inhabiting the red cedar, as well as other culture material. The locality is an interesting one, and deserving of further uredinological exploration.

We spent two days at Aiken, in the highlands of South Carolina, where Mr. Ravenel lived after the Civil War had swept away the family wealth. It was here that the work on his Fungi Americani Exsiccati was done. We wished especially to obtain further knowledge of Roestelia hyalina, a highly characteristic rust on Crataegus which is only known from Ravenel's original collection made at Aiken and distributed in 1878 as no. 37 in his Fungi Americani. We hoped to find a telial form from which the Roestelia could be grown, as we had done last year in the similar case of an isolated Rocstelia from central Kentucky. ${ }^{3}$ Unfortunately we failed to obtain any trace of the sought for rust, although we secured other culture material.

During the week following my associate, Mr. Kern, joined a company from the Missouri Botanical Garden at St. Louis, in a day's collecting along the bluffs of the Mississippi River south of St. Louis, securing culture material chiefly of grass and sedge rusts.

Another brief but important trip was made by Mr. Kern the first week in June to Leland in the northern part of the southern peninsula of Michigan, about 300 miles north of Lafayette. Ind. This was in consequence of observations made by Mr. Kern and the writer in that locality during the previous September. Hornlike aecia on Sorbus, Aronia and Amelanchier are quite common in the northern United States and Canada, and often occur in herbaria, usually under the name Roestelia cornuta. Morphological studies made by Mr. Kern convinced him some time ago that the similar aecia on the three host genera belong to three independent species of rusts, and since then we have been trying to secure suitable material for cultures. Last year we were able to show that telia of Gymnosporangium cornutum on the branches of Juniperus Sibirica produced the aecia on Sorbus, and that telia of G. Darisii on the leaves of the same host produced the aecia on Aronia. ${ }^{4}$ In searching in northern Michigan for clues

${ }^{8}$ Mycol. I : 226. 1909.

${ }^{4}$ Mycol. I: 240-242. 1909. 


\section{1}

to the Amelanchier form we most fortunately found a very small weather-beaten plant of Amelanchier not over six or eight inches high, bearing at the time about a score of leaves, and every leaf thickly covered with the characteristic horn-like aecia. No other plants of Amelanchier infected with the same sort of aecia could be found in the region, although they often bore aecia of other species. The plant in question did not occur near Juniperus Sibirica, although that juniper was very common, but much to our surprise was associated with Juniperus horizontalis, a trailing form of the red cedar, that produces circular mats up to fifty feet in diameter and rises only three to five inches from the ground. No other form of red cedar occurs in the region, and even this one is not abundant. In the midst of one of these red cedar mats, some six feet in diameter, we found on September 7 the heavily infected Amelanchicr just mentioned. It was too late in the season to hope to find telia. We did, however, detect some remains of what appeared to be telial galls on the larger branches close to the infected Amelanchicr, from which the aecia might have been derived. It was to ascertain if telia subsequently developed on this particular red cedar, and, if so, to secure some for cultures, that Mr. Kern again visited Leland. The highly satisfactory results of the trip are given later in this paper under the report of cultures of species never before recorded.

In this connection an error in the report of cultures for 1908 should be pointed out. The record of Gymnosporangium Davisii Kern, ${ }^{5}$ should have been listed among "Successful cultures reported for the first time." Studies have since shown that the form grown by Dr. Ed. Fischer of Bern, Switzerland, and which he subsequently named $G$. Amclanchieris is quite distinct from G. Davisii. The aecial host of the European form is a true Amelanchier (service-berry), and not an Aronia (choke-berry). The assumption that it was an Aronia, a genus not represented in the Swiss flora, came from confusion in interpreting the synonymy. The very similar aecia on Amelanchier in America produce a gall on the stems of the red cedar ,as the present season's work has demonstrated, while the aecia on Amelanchier in Europe produce small sori on the leaves of the common juniper. The

${ }^{5}$ Mycol. I : 241-242. I909. 


\section{irthlo: Clltures of Uredineae ix igo9 152}

whole paragraph beginning with the third line on page 242 of the last season's report is largely irrelevant, and should be stricken out.

Miost of the experimental part of the culture work of each year is clone in the spring, and while in progress it wholly absorbs the time of one person in addition to that of the regular workers in the department. This year Miss Louise M. Falk, of Davenport. Iowa, a senior honor student in the University of Iowa, was recommended for the position by Professor Thomas H. Macbricle. Miss Falk was in charge of the work from April I to June 3. She showed great enthusiasm and assiduity in conducting the cultures, although the turmoil of building and moving put the possibility of entirely satisfactory manipulation out of the question, as well as introduced most annoying interference. As for the year or two past, most of the cedar rust cultures were made by Mr. Kern. The investigations as a whole are a part of the work conducted by the botanical department of the Indiana Experiment Station, and are financed from the Adams fund appropriated by the general government for scientific research.

Those who assisted this year by supplying culture material and communicating field observations are most gratefully mentioned. Mr. E. Bethel, Denver, Colo., heads the list with fortysix collections of culture material. Messrs. J. F. Brenckle, Kulm. N. D.. J. M. Bates, Red Cloud, Neb., and W. P. Fraser, Pictour. Nova Scotia, each sent between twenty and thirty collections, while a much smaller number was sent by Messrs. O. E. White, Brookings, S. D., A. O. Garrett, Salt Lake City, Utah, C. F. Baker, Claremont, Calif., J. J. Davis, Racine, Wis., E. Bartholomew, Stockton, Kans., E. WV. Olive, Brookings, S. D., John L. Sheldon, Morgantown, W. Va., F. D. Heald, Austin, Texas. H. W. Barre, Clemson College, S. C., IV. P. Kelley, Honolulu, Hawaii, F. E. Lloyd, Zacatecas, Mex., Aven Nelson, Laramie, Wyo., F. L. Stevens, West Raleigh, N. C., and Guy W. Wilson, Fayette, Iowa. Plants for particular culture work were sent by Dr. IVilliam Trelease, of the Missouri Botanical Garden, St. Louis, Mo. Thanks are extended to the above individuals, and to others who aided in the year's investigations. 
During the present season 178 collections of material with resting spores and 18 collections with active spores were employed, from which 684 drop cultures were made to test the germinating condition of the spores. Out of the 178 collections with resting spores 95 could not be brought to germination, leaving 83 collections of available material to serve for the projected cultures. These 83 collections with resting spores and 18 with active spores belonged to about 70 species of rusts. Altogether 345 sowings were made, employing for the purpose 97 species of hosts, these being grown in pots.

The results of this work are given in the following paragraphs, and are divided into negative results, positive results with species whose life cycles have already been ascertained by the writer or other investigators, and positive results with species whose life cycles are now first completed and placed on record.

Negative Results:-Quite a number of collections gave good germination of the spores, and these were sown on plants in the hope of discovering the alternate host, but no infections were secured. The following may be recorded to serve for reference in future studies, although not so much importance can be attached to these results as in former years, owing to unsatisfactory conditions, as stated above:

I. Puccinia on Carex tenella Schk., collected at Pictou, Nova Scotia, by Prof. W. P. Fraser, was sown on Boehmeria cylindrica, Apocynum cannabinum, Lepargyraea canadensis, Symphoricarpos pauciflorus, Rudbeckia laciniata and Iva frutescens, with no infection.

2. Puccinia on Carex tenuis Rudge, collected at Pictou, Nova Scotia, by Prof. W. P. Fraser, was sown on Aster paniculatus, Solidago canadensis, Erigeron annuиs, Onagra biennis and Ambrosia trifida, with no infection.

3. Puccinia on Carex Bomplandii minor Vasey, collected at Granby, Colo., by Mr. E. Bethel, was sown on Aster Tweedii, A. paniculatus, $A$. multiflorus and $A$. Drummondii, with no infection. The determination of the host was made by Mr. Theo. Holm.

4. Puccinia on Carex Backii Boott, collected in Colorado, by 


\section{Artulr: Clitures of Uredineae in igogt? 219}

Mr. E. Bethel, was sown on Lactuca satiz'a, Artemisia dracunculoides. Ambrosia trifida, Grindelia squarrosa and Laciniaria spicata, with no infection. The determination of the host was made by Mr. Theo. Holm.

5. Puccinia on Carex siccata Dewey, collected at Kulm, N. D., by Dr. J. F. Brenckle, was sown on Ambrosia trifida and Carduus undulatus, with no infection.

6. Peccinia RUbigo-vera Auct., on Hordeum jubatum, collected at Brookings, S. D., by Mr. O. E. White, was sown on Lycopsis aricnsis (on 3 different dates), Heliotropium curassaricum (on 3 dates), Myosotis palustris (3 dates), Lithospermum canescens, L. ariense, L. angustifolium, Hydrophyllum zirginicum, Ceanothus americanus, Callirrhoe involucrata, Symphoricarpos racemosus, Petalostemon purpurpeum, Laciniaria punctata and Ambrosia trifida, with no infection.

7. Puccisia Distichlidis E. \& E., on Spartina gracilis Trin., collected at Kulm, N. D., by Dr. J. F. Brenckle, was sown on Leparygraca canadensis, Mimulus ringens, Symphoricarpos recemosus, Polygala Senega, Grindelia squarrosa and Carduus undulatus, with no infection.

8. Puccinia substerilis E. \& E., on Stipa viridula Trin., collected at Eldorado Springs, Colo., by Mr. E. Bethel, was sown on Tithymalis arkansanus coloradensis, Arabis Holboellii, Grindelia squarrosa and Eupatorium serotinum, while another collection with same data was sown on Viola sororia, Mimulus ringens, Myosotis palustris, Aster ericoides and A. multiflorus, all with no infection.

9. Puccinia striatula Peck, on Calamagrostis canadensis (Michx.) Beauv., collected at Wind Lake, Wis., by Dr. J. J. Davis, was sown on Thalictrum alpinum, T. dioicum, T. purpurascens, Actaea alba, Phacelia bipinnatifida, Hydrophyllum virginicum and Polygonatum biflorum, with no infection.

io. Peccinia virgata Ellis \& Ev., on Chrysopogon avenaceus (Michx.) Benth., collected at Asheville, N. C., by Mr. F. D. Kern, was sown on Dirca palustris, Viola sororia, Hydrophyllum cirginicum, Mimulus ringens, Chelone glabra, Symphoricarpos pauciflorus and Ambrosia trifida, with no infection. Similar 
material from Nebraska was sown two years ago on four other species of hosts. ${ }^{6}$

ir. Puccinia Ellisiana Thüm., on Andropogon scoparius Michx., collected at Ayr, Neb., by Rev. J. M. Bates, was sown on Ceanothus americanus, Aesculus glabra, Lepargyraea canadensis, Symphoricarpos racemosus, Mimulus ringens, Laciniaria punctata, Lithospermum angustifolium, Chelone glabra, Ranunculus septentrionalis and Mertensia virginica.

Another collection on the same host and by the same collector from Scotia, Neb., was sown on the first six hosts mentioned, and also on Laciniaria spicata, L. scariosa, Cassia Chamaecrista, Hydrophyllum virginicum, Polygala Senega, Petalostemon purpureum and Phacelia bipinnatifida.

The same species of rust on $A$. glomeratus (Walt.) B.S.P., collected at Asheville, N. C., by Mr. F. D. Kern, was sown on Cassia Chamaecrista, Lepargyraea canadensis and Petalostemon purpureum, as in the preceding cases, and also on Baptisia tinctoria, Abronia fragans and Viola cucullata.

The results were uniformly negative, there being no infection. In the two preceding years this rust was sown on nineteen other species of hosts. ${ }^{7}$

12. Uromyces graminicola Burr., on Panicum virgatum L., collected at St. Paul, Neb., by Rev. J. M. Bates, was sown on Callirrhoe involucrata, Althaea rosea, Hibiscus militaris, Sidalcea oregana and Viola cucullata, with no infection. Similar material was sown last year on four of these same hosts, and on four other species without effect. ${ }^{8}$

I3. Uromyces Junci (Desm.) Tul., on Juncus Balticus Willd., collected at Kulm, N. D., by Dr. J. F. Brenckle, was sown on Pulicaria dysenterica, with no infection. Another collection on the same host from Colorado, sent by Mr. E. Bethel, was sown on Pulicaria dy'senterica, both seedlings and strong shoots, and on Grindelia squarrosa and Arnica sp., with no infection. In I907 a similar collection from Nebraska was sown on fifteen other species of hosts. ${ }^{\circ}$ This common Americaln rust is usually

'See Jour. Myc. 14: Io. I908.

'Jour. Myc. 14: 10. 1908; Mycol. I: 231. 1909.

${ }^{8}$ Mycol. I: 232. I909.

'See Jour. Myc. 14: I2. I908. 


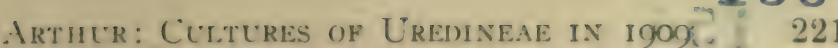

considered to be the same as the one in Europe from which it takes its name. The experiments of Fuckel, Plowright, and E. Fischer have shown that the European form produces aecia on Pulicuria dy'senterica, and the failure of the American form to do so may mean that the two are distinct species, or that there are physiological races on different hosts. Further studies are necessary to decide the question.

14. Cromyces acuminatus Arth., on Spartina cynosuroides IVilld., collected at Fayette, Iowa, by Prof. Guy West Wilson, was sown on Steironcma ciliatum, S. lanceolatum and Polemonium reptans, with no infection. Similar material from northern Indiana has been sown in previous years on six other hosts, and also four times on Stcironema ciliatum and two times on $S$. lanceolatum, without infection. ${ }^{10}$

Some years ago in a morphological study of all collections of Uromyces on Spartina then available the writer decided ${ }^{11}$ that the form from the salt marshes of the Atlantic coast, known under the name $U$. Spartinae Farl., having somewhat larger teliospores and urediniospores, the former with more rounded apices, and the latter with thicker walls, than the western form mentioned above, occurred also in the interior of the continent, and could not be clearly separated from $U$. acuminatus. Recently my associate, Mr. F. D. Kérn, has restudied the two forms, with all the data that have accumulated in the decade since my own study was completed, and is able to supplement the morphological differences which I pointed out with others, and concludes that the two forms represent distinct species. He gives the distribution of $U$. acuminatus as the wet, alluvial prairies of Iowa, Minnesota, and adjoining states, extending eastward to northern Indiana, while $U$. Spartinae is found in saline soils from Alberta southwestward to Wisconsin and Kansas, and along the Atlantic coast from Nova Scotia to Florida. Reexamining the successful cultures with Uromyces on Spartina, made in 1905 and 1907 , the material for which was sent from western Nebraska, ${ }^{12}$ it is found that the culture material agrees with $U$. Spartinae Farl. Putting all the data together, the writer's suspicions, recorded

\footnotetext{
${ }^{10}$ See Jour. Myc. 10: 9. 1904; 13: 193. 1907.

${ }^{11}$ Bot. Gaz. 34: 3. 1902.

12 Jour. Myc. 12: 24. 1906; and 14: 17. 1908.
} 
both in the discussion of his morphological studies and his cultural reports, cited above, that there are two species of Uromy'ces on Spartina, are confirmed. The aecial form of $U$. Spartinae Farl. occurs on Steironema ciliatum and S. lanceolatum, and the aecial form of $U$. acuminatus Arth. is yet unknown, although field observations made by Mr. Guy West Wilson inclicate that it may occur on Polemonium reptans.

I5. Gymnosporangium sp., on Juniperus zirginiana L. collected at the Santee Canal, near Monks Corners, S. C., by Mr. F. D. Kern, was sown March 24 on the leaves of Cratacgus punctata, Amelanchier erecta, and $C y$ donia z'ulgaris, with no infection. On April I it was sown again on the same three species and on Malus coronaria, with no infection. It was sown again April I4 on Crataegus sp., and Malus Malus, still with no infection. On April 26 a sowing was made on Crataegus coccinea and Pyrus communis (Kiefer's Hybrid), and on May I4 a further sowing on Crataegus cerronis, Aronia arbutifolia, Sorbus americana and Porteranthus stipulatus, wholly without infection.

The failure to secure infection, although sowings were made on all the genera known to harbor aecia of the Gymnosporangia in the eastern United States, was probably due to the maturity of the leaves, or to some accident. It is certain on morphological grounds that this cedar rust is not a form at present recognized under established names. The rust produces large brown sori, often in series, extending along the bark of the larger branches. It has somewhat the general appearance of Gym. nidus-avis, causes a similar swelling of the branches, but differs in having prominently projecting sori, even before gelatinization, which are much roughened on the surface.

Successful cultures supplementing previous WORK: The following species of rust were successfully grown and the facts supplement those obtained from previous cultures in this series or those recorded by other American or European investigators. In a number of cases the data here presented materially extend the previously available knowledge regarding the several species.

I. Puccinia Peckit (DeT.) Kellerm., on Carex lanuginosa Michx., collected at Red Cloud, Neb., by Rev. J. M. Bates, was 
sown May 19) on Sambucus canadensis and Onagra biennis, giving no infection on the former, but giving very abundant pyenia on the latter May 28, followed by aecia June 6.

Four collections on the same host, made by Dr. J. F. Brenckle, at Kulm, N. D., were used for three successful sowings on Onagra biennis, giving rise to pycnia in seven to twelve days, followed by aecia in five to seven days more. Sowings on Gaura biennis and Carduus undulatus gave no infection.

A collection on Carex trichocarpa Muhl., made by Mr. F. D. Kern at White House, St. Louis Co., Mo., after having been sown on Sambucus canadensis with no infection, was sown April 2I on Gaura bicnnis, giving rise to pycnia April 30, and aecia May $10 .{ }^{13}$

2. Puccinia Caricis (Schum.) Schröt, on Carex aristata R. Br., collected at Kulm, N. D., by Dr. J. F. Brenckle, was sown April 6 on Urtica gracilis, giving rise to pycnia April I 3 and aecia April 17 , both in great abundance. A similar sowing April 21 on Bochmeria cylindrica gave no infection. Another sowing May 4 on both hosts gave no infection on Bochmeria cylindrica, but produced the richest possible infection on Urtica gracilis, showing pycnia May 9, and aecia May 15. Beside adding another species of Care.r to the list of hosts supplying culture material for this rust, ${ }^{1+}$ the results indicate that Boehmeria is not an aecial host.

It may be well to point out in this connection that the usual citation of Rebentisch for this species of rust is erroneous. This author in his Florae Neomarchicae, 1804, page 356, describes Puccinia Caricis as a new species in the following words: "Sparsa minutissima punctiformis, capsulis cylindraceis apice utrinque attcnuatis. In foliis Caricis praccocis Jacq." Only the one host species is named, neither the description nor the host tally with those known to belong to the rust having its aecia on Urtica, as may be seen by consulting Sydow's Monographia Uredinearum. They, however, do agree well with those given by Sydow under Puccinia silratica, to which species Rebentisch's name should doubtless be referred.

${ }^{13}$ For previous cultures see Bot. Gaz. 35: I3. 1903: Jour. Myc. 8: 55. 1902; II : 58. 1905; 12: $15.1906 ; 13: 195.1907$; and Mycol. $x$ : 233. 1909.

${ }^{14}$ For previous cultures see Bot. Gaz. 29: 270. 1900; 35: 16. 1903; Jour. Myc. 8: 52. 1902; 12: 15. 1906 ; and 14: 14. 1908. 
3. Puccinia universalis Arth., on Carex stenophylla Wahl., collected at Eldorado Springs, Colo., by Mr. E. Bethel, was sown April 26 on Arabis Holboelli, Sambucus canadensis, Urtica gracilis and Artemisia dracunculoides. All remained free from infection except the last, on which pycnia appeared May 5, and aecia May I4. This is a confirmation of the result obtained in 1907. ${ }^{15}$ In making the cultures and writing up the results of that year it was overlooked that the combination which was then established had been repeatedly suggested by Rev. J. M. Bates. In the spring of $1906 \mathrm{Rev}$. Bates sent a collection of rust on Carex stenophylla, obtained at Boelus, Neb., on June 25, I906, and on the packet he wrote that it was associated with aecia on Artcmisia longifolia. This came too late in the season to be tested by a culture. In a letter received in September of the same year he stated that his field observations made it almost certain that this Carex rust and the Artemisia aecia were alternate forms of one species. Both my associate, Mr. Kern, and myself were at that time of the opinion that the aecia on Artcmisia belonged to the telia on the same host, and so firmly did we believe this error that when material for cultures was at hand the following spring, we had forgotten Rev. Bates' suggestion, and we also overlooked the memorandum in our book of suggestions for future work.

4. Puccinla Caricis-Asteris Arth., on Carex festiva Dewey, the host being determined by Mr. Theo. Holm, collected August 15, 1908, at Granby, Colo., by Mr. E. Bethel, was sown May I7 in accordance with the suggestion of the collector on Aster adscendens Lindl. (A. Tweedyi Rydb.), giving rise to pycnia which were first noticed May 3I, although they may have appeared earlier, and to a few aecia June 6. A sowing was also made at the same time on Agoseris glauca with no infection.

Another collection made in the same vicinity five days later was sown May 22 on Aster adscendens and produced abundant pycnia May 29, and many aecia June 4. These cultures bring forward a new set of hosts, and show the species to be of wide distribution in America. ${ }^{16}$

${ }^{15}$ See Jour. Myc. 14: 21. 1908.

${ }^{10}$ For previous cultures see Bot. Gaz. 35: 15. 1903 ; Jour. Myc. 8: 54. 1902 ; and 14 : 13. 1908. 


\section{Arthur: Cultures of Uredineae in iö 160

5. Puccinia subnitens Diet., on Distichlis spicata (L.) Greene, collected at Kulm, N. D., by Dr. J. F. Brenckle, was sown April 23 on Corydalis aurea Willd., with no infection, and also on Atriplex hastata, giving pycnia May 3, and aecia May 12. Another sowing was made April 24 on Corydalis semperirens (L.) Pers. (C. glauca Pursh), with no infection, and also on Atriplex hastata and Chenopodium album, both of which gave infection, showing pycnia April $3 \mathrm{r}$, and aecia later. ${ }^{17}$ The chief object in again growing this rust was to see if it would infect species of Corydalis on which occur Aecidium fumariaccarum Kellerm. \& Sw. (A. Corydalis Webber), the aecia and aeciospores of which resemble those belonging to Puccinia subnitcns. The results, however, are inconclusive, and further cultures must be attempted before the question can be settled.

6. Puccinia amphigena Diet., on Calamovilfa longifolia (Hook.) Hack., collected at Kulm, N. D., by Dr. J. F. Brenckle, was sown May 22 on Smilax hispida, and gave numerous pycnia May 31, and aecia June 4. This extends the geographical range from which material has been received for successful cultures. ${ }^{18}$

7. Puccinia fraxinata (Schw.) Arth., on Spartina cynosuroides Willd., collected at Kulm, N. D., by Dr. J. F. Brenckle, was sown May 22 on Fraxinus lanccolata, giving rise to pycnia May 29 , and aecia June $4 \cdot \cdot^{10}$

8. Puccinia Phragmitis (Schum.) Körn., on Phragmites communis Trin., collected at Scotia, Neb., by Rev. J. M. Bates, was sown May I4 on Rumex crispus, giving rise to pycnia May 22, and aecia May 29, both in the greatest abundance. Another collection by the same person, made at Grand Island, Neb., was sown May 17 on $R$. crispus, giving abundance of pycnia May 23, and aecia May 29. ${ }^{20}$

9. Puccinia obliterata Arth., on Agropyron sp., collected

${ }^{28}$ For previous cultures see Bot. Gaz. 35: 19. I903; Jour. Myc. II : 54. 1905; 12: 16. 1906; 13: 197. 1907; I4: 15. 1908; and Mycol. I: 234. 1909.

${ }^{18}$ For previous cultures see Bot. Gaz. 35: 20. 1903; Jour. Myc. II : 57. 1905; 12: 16. 1906; and 14: 15. 1908.

${ }^{19}$ For previous cultures see Bot. Gaz. 29: 275. 1900; Jour. Myc. 11: 57. 1905; 12: 16. 1906; 14: 14. 1908; and Mycol, 1: 236. 1909.

${ }^{20}$ For previous cultures see Bot. Gaz. 29: 269. 1900: Jour. Myc. 9: 220. 1903 ; and 14 : 15.1908. 


\section{1}

August 15, 1908, at Granby, Colo., by Mr. E. Bethel, was sown April $2 \mathrm{I}$ on Thalictrum alpinum and $T$. dioicum. There was no infection on the latter host, but on the former it was abundant, showing aecia May 6. Pycnia were so scantily produced that it required an extended search, aided with sections from the affected spots to discover any. A careful morphological study reveals no difference between the telial material used for this culture together with the aecia produced by it, and the telial material on the same host used last year, together with the aecia then produced on Aquilegia. ${ }^{21}$ The gross appearance of the infected areas, the manner of the hypertrophy, and the remarkable paucity of pycnia, also combine to indicate that the two cultures belong to one species, although the production of aecia on both Thalictrum and Aquilegia by a single species is not in accordance with similar studies made in Europe. ${ }^{22}$

io. Puccinia Muhlenibrgiae Arth. \& Holw., on Muhlenbergia glomerata Trin., collected at Stockton, Kans., by Mr. E. Bartholomew, was sown May 17 on two plants of Callirrhoe involucrata, both giving rise to numerous pycnia May 3I, and to aecia June 6 in one case and June 12 in the other. At the same time it was sown on Napaea dioica, Althaea rosea and Sidalcea sp., with no infection. These hosts are known to bear aecia of the same appearance and morphological structure as those secured by the culture on Callirrhoe, and the reason why they were not affected by the sowings is not clear, unless this species of rust is made up of races. ${ }^{23}$

iI. Puccinia Imp.tientis (Schw.) Arth., on Elymus striatus Willd., collected at Lafayette, Ind., by Mr. A. G. Johnson, was sown May 6 on Napaea dioica, with no infection, and at the same time on Impatiens aurea, giving rise to pycnia May I5, and aecia in abundance May 25. Another collection on the same host, made by Mr. F. D. Kern at White House, St. Louis Co., Mo., was sown May II on I. aurea, producing pycnia May 2I, and aecia May 29. It was also sown at the same time and produced no infection on Napaea dioica, Callirrhoe involucrata, Thalictrum

${ }^{21}$ See Mycol. I: 250. I909.

${ }^{22}$ See Klebahn, Wirtsw. Rostpilze 275, 276. 1904.

${ }^{23}$ For previous cultures see Mycol. I : 251. 1909. 


\section{Artiler: Cultures of Uredineae in igog 162}

dioicum, Actaca alba, Caulophyllum thalictroides, Boehmeria cylindrica, Myosotis palustris, Mimulus ringens, Polemonium reptans, Hydrophyllum airginicum, Polygala Senega, Dirca palustris, Psoralea Onobrychis and Ipomoea pandurata.

Aeciospores from Impatiens aurca IIuhl., were sown on three species of Elymus. For this purpose small plants bearing aecia were taken from the field, where they grew close together, and had presumably received infection from one source. These were established in pots, and the pots adjusted over the plants of Elymuls to be infected, so the spores would drop of themselves upon the leaves of the grass, belljars being used as usual to secure the right degree of moisture for the germination of the spores. In this manner aeciospores were sown June 4 upon Elymus sirginicus L.. E. canadensis L. and E. striatus Willd. In all three cases uredinia began to show June 17 , and continued to increase for some time, but the conditions were not such as to keep the plants in healthy condition for the maturing of telia.

Former cultures ${ }^{24}$ had demonstrated the genetic connection between the aecia on Impatiens and telia on Elymus virginicus. The present season's work indicates that the rust on all species of Ely'mus in the region east of the Rocky Mountains belongs to one species, Puccinia Impatientis.

12. Peccinili poculiformis (Jacq.) Wettst., on Agropyron pscudorepens Scribn. \& Sm., collected at Kulm, N. D., by Dr. J. F. Brenckle, was sown May 4 on Berberis vulgaris, giving rise to pycnia May 12, and numerous aecia May 24. Another collection on Sitanion longifolium J. G. Sm., made at Tolland, Colo., 9,000 feet altitude, by Mr. E. Bethel, was sown May I7 on Berberis s'ulgaris, and gave pycnia May 29, but owing to maturity of the leaves did not reach the production of aecia. Still another collection on Sitanion longifolium, made at Eldorado Springs, Colo., 4.500 feet altitude, by Mr. E. Bethel, was sown April 26 on Berberis i'ulgaris, and gave pycnia May 3, and aecia May 12 , both in great abundance. On May 17 the barberry plant bearing aecia, produced in the last culture, was arranged over a pot in which young wheat plants (Triticum vulgare Vill.) were growing. in such a manner that the aeciospores could fall

"See Bot. Gaz. 35: 18. 1903; Jour. Myc. 10: 11. 1904; and 11: 57. 1905. 
upon the wheat leaves. On May 29 urediniospores began to show, and their abundance increased for some time, but owing to the lateness of the season the wheat plants did not flourish, and in consequence teliospores were not formed.

This species of rust, which is the most injurious cereal rust known, is very common throughout the country, not only on cereals, but on many wild grasses. It has now been grown ${ }^{25}$ in our series of cultures from telia on A gropyron repens from Vermont, A. tcnerum from Iowa and Nebraska, Agrostis alba from Indiana and New York, Cinna arundinacea from Indiana, Elymus canadensis from Iowa and Wisconsin, and the two hosts mentioned above. In 1907 the aeciospores raised from telia on Agrostis alba obtained in Indiana were used to produce infection on wheat (Triticum v'ulgare) and barley (Hordeum z'ulgare). and in 1908 aeciospores raised from telia on Agropyron tenerum obtained in Nebraska were used for infection on oats (. Av'ena satica). This year the aeciospores raised from telia on Sitanion longifolium obtained in Colorado produced infection on wheat. More extended work is planned in regard to the problem of the transfer of this pernicious black or stem rust from wild grasses to the cultivated cereals, but enough has been accomplished to warrant the statement that although in the uredinial stage this rust shows racial strains that inhibit the ready transfer from one species of host to another, as has been shown by many European and American investigators, yet in the aecial stage racial strains play no part, and the barberry acts as a bridging host between each and every other gramineous host.

13. Puccinia substeril.rs E. \& E., on Stipa viridula Trin., collected April 16 at Eldorado Springs, Colo., by Mr. E. Bethel, bore abundance of amphispores, which were sown April 29 on plants of Stipa viridula, and gave rise to urediniospores in abundance, first observed May 24. A sowing at the same time on Stipa spartea gave no infection.

14. Uromyces Andropogonis Tracy, on Andropogon rirginicus L., collected at Morgantown, W. Va., by Dr. John L. Sheldon was sown June 4 on Viola cucullata, giving ten groups of pycnia,

${ }^{25}$ For previous cultures see Jour. Myc. 8: 53. I902; II : $57.1905 ;$ I2: 17. 1906; 13: 198. 1907; and 14: 16. 1908. 
first showing June 12. The leaves matured so rapidly that no aecia were formed. A sowing at the same date on Viola primulifolia gave no infection. This species of rust has been grown upon Viola by Dr. John L. Sheldon, ${ }^{20}$ but previous attempts made in my own laboratory have failed. ${ }^{27}$ The reason for the failures seems to be the tardiness in making the cultures, by which the violet leaves are too mature and ripen so rapidly that infection is not secured. I am indebted to Dr. Sheldon for the suggestions, field observations and culture material, which have enabled me to add this species to the list of completed life cycles.

15. Uromyces Sp.urtinae Farl,, on Spartina cynosuroides Willd. collected at Kulm, N. D., by Dr. J. F. Brenckle, was sown April 23 on Lysimachia quadrifolia, with no infection, and at the same date on Stcironema ciliatum and S. lanccolatum, giving rise to pycnia May 5 on the former and May 8 on the latter. In both cases growth did not extend to the formation of aecia owing to the feeble condition of the host plants. ${ }^{28}$ The confusion of this species of rust with Uromyces acuminatus Arth. has already been discussed above among unsuccessful cultures.

16. Gymnosporingium gLobosum Farl, on Juniperus virginiana L., collected at Asheville, N. C., by Mr. F. D. Kern, was sown May 15 on Malus Ioensis, Crataegus punctata and C. cocclinea, with no infection on the first and second, but on the last giving rise to pycnia May 25 in abundance, followed by aecia which were mature July $26 .^{20}$

17. Gymnosporangium clavipes C. \& P., on Juniperus sibirica Burgsd., collected at Leland, Mich., by Mr. F. D. Kern, was sown June 5 on the fruit of Amelanchier erecta, giving rise to pycnia June I4, and to mature aecia August 3, both in abundance. At the same time it was sown on the leaves of Crataegus punctata. giving rise to numerous pycnia, but as the plant was not well established further development was soon checked. ${ }^{30}$ There ap-

so Torreya 9: 55 . 1909 .

"See Mycol, I: 232. 1909.

${ }^{28}$ For previous cultures see Jour. Myc. 12: 24. 1906; and 14: 17. 19018, under the name $U$. acuninatus.

${ }^{29}$ For previous cultures see Jour. Myc. 13: 200. 1907; 14:18.1908: and Mycol. I : 239. 1909.

${ }^{3 n}$ For previous cultures see Jour. Myc 14: 18. 1908; and Mycol. I: 239. 1909 . 
pears to be no noticeable difference between the pycnia and aecia grown this year from telia on the true juniper and those grown last year from telia on the true cedar, thus confirming the unique character of this species of rust in growing upon hosts of the two quite distinct sections of the genus Junipcrus.

i8. Gymnosporangium nidus-avis Thax. on Juniperus virginiana L., collected at Asheville, N. C., by the writer, was sown March 22 on Amelanchicr canadensis, without infection, and at the same time on Cratacyus Pringlci and Malus Iocnsis, both giving rise to an abundance of pycnia April 6. The infection on Crataegus did not perfect aecia, but that on Malus matured aecia in abundance by April $27 .^{.1}$

The telia of this collection were on the main branches of a tree thirty feet high, and when found were fully expanded. They formed wavy masses standing out two centimeters or more from the bark and extending in long lines of four or five decimeters, like orange colored ruffles or frills. The appearance was that of a large Tremella, and so unlike that of any Gymnosporangium before seen that not until it was examined under the microscope after returning to Lafayette was it accepted as a rust. It was found that the frills were the consequence of the large sori forming in rows and cracking the bark longitudinally.

19. Granosporangium Betheli Kern, on Juniperus scopulorum Sarg., collected in Colorado by Mr. E. Bethel, was sown May i4 on Crataegus cerronis, and gave rise to pycnia May 22 in abundance, and to first appearance of aecia June 14, the aecia being fully mature August $3 \cdot{ }^{32}$

20. Gymnosporangium cornutum (Pers.) Arth., on Junipcrus sibirica Burgsd., collected at Leland, Mich., by Mr. F. D. Kern, was sown June 5, on Aronia nigra and Amelanchier erecta with no infection, and at the same time on Sorbus americana, giving an abundance of pycnia June. I5, but no aecia were formed owing to the weakness of the host plant. Another sowing was made from the same material June 7 on a cutting of Sorbus aucuparia placed in water, giving a few pycnia June 18 , but the

${ }^{31}$ For previous cultures see Jour. Myc. 14: 19. 1908.

${ }^{22}$ For previous cultures see Jour. Myc. I4: 23. I908; and Mycol. I: 240. I909. 


\section{Arthur: Cultures of Uredineae in roog 6231}

leaves soon died. Still another sowing was made June 14 on Sorbus americana, producing numerous pycnia June 26 , but the plant gradually died. ${ }^{38}$

2I. Gymnosporangium flormorme Thax., on Juniperus virginiana L., collected at Aiken, S. C., by Mr. F. D. Kern and the writer, was sown March 26 on Malus Malus with no infection, and at the same time on Cratacgus coccinca, giving pycnia in abundance April 12. The after development, however, was very slow, and by the middle of July aecia had only begun to show, and grew so very slowly that they did not reach full size, although observations were continued till November II. Another sowing. from the same material was made May 15 on the same host, resulting in a few pycnia, but no aecia. In both cases the infected leaves matured too rapidly for the very slow growing aecia, and besicles, the host used is not a species on which natural infection is likely to occur.

Previous cultures have been made by Dr. R. Thaxter at Cambridge, Mass., and Prof. F. S. Earle at Auburn, Ala. Only a slight notice of these cultures has been published. A description and historical account of the species was recently published by Mr. F. D. Kern. ${ }^{3+}$ The telial form of the species is very similar in appearance to that of the common Gy'm. Juniperi-virginianae.

22. Gyanosporangium exterum Arth. \& Kern, on Juniperus rirginiana L., a living plant a little over six inches high, which has been growing in the greenhouse since being brought from Mammoth Cave, Ky., by Mr. F. D. Kern and the writer a year ago, was sown May I4 on Porteranthus stipulatus (Gillenia stipulacca), and gave rise to an abundance of pycnia May 22. On June If the first aecia appeared, which were mature June 26. The work duplicates and confirms that of last year. ${ }^{35}$

23. Calyptospora colum naris (A. \& S.) Kühn, on Vaccinium pennsylianicum Lam., collected at Pictou, Nova Scotia, by Prof. W. P. Fraser, was sown June 16 by suspending the moistened stems bearing the rust over potted plants of Abies Fraseri. On July 8 abundance of aecia appeared, without being preceded by

${ }^{85}$ For previous cultures see Mycol. I: 240. I909.

s Bull. Torrey Club 35: 503. 1908.

\$For previous cultures see Mycol. I: 253. 1909. 


\section{8}

\section{Mycologia}

pycnia. European investigators have noted the absence of pycnia in this species, both in the field and in cultures. The suppression of the gametophytic sori, as in this case, is rare in heteroecious rusts.

This is the first culture yet made with American material. In I880 Hartig made cultures at Munich, Germany, by using aeciospores from Abies alba and teliospores from I'accinium Vitis-idaea, thus transferring in both directions. ${ }^{36}$ The most extensive cultures were made by Dr. G. Winter in 1885 and I886, in the garden of the Experiment Station at Halle, Germany: ${ }^{37}$ He successfully sowed teliospores on Abies nobilis, A. magnifica, A. concolor, A. balsamea and A. Frascri, natives of North America, and on eight other species of Abies, natives of various parts of the world.

After the sori made their appearance in our own cultures I wrote to Prof. Fraser, the collector of the culture material, describing the salient characters of the aecia, and inclosed infected leaves obtained by means of the culture. With this information he was able to go into the field and find the aecia on Abics balsamea, returning a collection which he made at Pictou, Nova Scotia, July 14, 1909, ${ }^{38}$ the first known collection from North America. This stage of the fungus is probably common throughout the country, and the fact that it has been seen but once is doubtless due to its early appearance, lack of accompanying hypertrophy and discoloration, evanescent character, and general inconspicuousness.

SuCCESSFul CUltures REPORTED NOW FOR THE FIRST TIME: The following species have never before been cultivated, in America or elsewhere, so far as the writer knows. Although the number is small, it includes most valuable additions to our knowledge of American rusts. The study of the cedar rusts, which has been greatly advanced by the spring excursions of the last three years for personal observation and collection of material, is approaching a full survey of the species of the eastern United States, although an unknown number of species remain in the western mountains yet to be investigated.

\footnotetext{
${ }^{36}$ See Klebahn, Die wirtsw. Rostpilze 391. 1904.

${ }^{\pi}$ Hedwigia 26: 28. 1887 .

${ }^{88}$ See Fraser, Science 30: 814. I909.
} 
1. Puccinia on Andropogon Hallii Hack., collected at Red Cloucl, Neb., by Rev. J. M. Bates, was sown June 3 on thirteen species of hosts with no infection, as follows: Carduus undulatus, Ambrosia trifida, Lithospermum canescens, Myosotis palustris, $\mathrm{Hy}$ drophyllum ziryinicum, Leparyyraea canadensis, Symphoricarpos parififorum, Napaea dioica, Bochmeria cylindrica, Thalictrum dioicum, Delphinium scaposum, Cassia Chamaecrista and Petalostemon purpureus. The same material was sown the day following on four other species with no infection, viz., Amorpha nana. Baptisia tinctoria, Psoralca Onobrychis and Xanthorylon americanum. Each of these hosts is known to harbor aecia whose telial connection has not yet been experimentally ascertained. The material being in unusually good condition an attempt was made to sow it on all unconnected aecial hosts available at the time, hoping in this way to strike the right one, no field clues having been secured. This is a precarious method, but in this instance it succeeded, as among the hosts was included Cinothus americanus, on which a sowing was made June 3 , giving rise to numerous pycnia June 12 , and an abundance of aecia June 22.

The telial form of this species was first detected by the writer while preparing the material for the third fascicle of Arthur and IJolway' Uredineae Exsiccatae, and was referred to Puccinia Cesatii Schröt, on account of the similarity of the urediniospores to those of that species. ${ }^{39}$ Sydow in his Monograph rightly called this reference in question, and suggested that it might be a new species, but did not give a name or description. ${ }^{40}$

The aecial form of this species was described by Ellis and Kellerman in 1884, under the name Aecidium Ceanothi, from a collection made at Manhattan, Kans. The form is not only known from Kansas, but also from Nebraska, and northwestern Wisconsin.

Puccinia Ceanothi (Ellis \& Kellerm.) nom. nov. (Aecidium Ceanothi Ellis \& Kellerm., Bull. Torry Club II: II4. I884.)

$\mathrm{O}$ and I. On Ceanothus or'atus Desf., Manhattan, Kans., May 20, 1884, W. A. Kellerman (type) ; Rooks Co., Kans., May, I898,

${ }^{39}$ Bull. Lab. Nat. Hist. Iowa Univ. 5: 181. I9or.

${ }^{6}$ Sydow, Monog. Ured, I: 723. 1903. 
E. Bartholomeru; Nebraska, I899, A. J. Bell; Gordon, Wis., July. I2, I907, J. J. Davis.

II. Uredinia hypophyllous, oblong-linear, pulvinate, early naked, chestnut-brown, only slightly pulverulent; urediniospores globose or nearly so, $23-33 \mu$ in diameter, wall cinnamon-brown, uniformly thick, $3-6 \mu$, finely and closely verrucose, pores five or more, scattered.

III. Telia hypophyllous, oblong or linear, early naked, pulvinate, firm, chocolate-brown; teliospores broadly ellipsoid or obovate, 22-30 by $30-40 \mu$, somewhat constricted at the septum, rounded at both ends, or narrowed below, wall smooth, medium thick, $3 \mu$, much thickened at apex, $6-10 \mu$, chestnut-brown; pedicel colored, once to twice length of spore.

On Andropogon Hallii Hack., Manhattan, Kans., no date, M. A. Carleton; Howard Co., Neb., September, I889, H. J. Webber: Kennedy, Neb., Sept. 7, 1908, J. M. Bates (Barth., Fungi Columb. 2756); Red Cloud, Neb., May 7, 1909, J. M. Bates.

2. Gymnosporangium exiguum Kern, on Juniperus virginiana L., collected at Austin, Texas, by Dr. F. D. Heald and Mr. F. A. Wolf, was sown April 26 on Amelanchier canadensis with no infection, and at the same time on Crataegus Pringlci, giving abundant pycnia May 6, and aecia June 26 .

This southernmost species of cedar rust was described a year ago $^{41}$ from telial material that was collected in the vicinity of that used for the cultures. The telial description may now be supplemented by a description of the pycnia and aecia. Only one collection of aecia from the field is yet known that can be assigned to this species. It was obtained at Boerne, Texas, not far from San Antonio, and is to some extent on the leaves, but mostly on the fruit of some.undetermined species of Crataegus. While trees of red cedar of more than one species are abundant in southern Texas where the rust is found, trees of Crataegus are rare, and the rust is probably not common.

O. Pycnia fruiticolous and epiphyllous, gregarious, in irregular groups I-4 mm. across, on discolored hypertrophied areas, prominent, conspicuous, honey-yellow soon becoming blackish, globoid or depressed globoid, $150-165 \mu$ in diameter by $100-130 \mu$ high; ostiolar filaments $50-65 \mu$ long.

I. Aecia fruiticolous and hypophyllous, sparsely arranged in irregular groups, causing considerable hypertrophy of the veins,

${ }^{41}$ Bull. Torrey Club 35: 508. 1908. 
Artilur: Cultures of Urenineae in ino6 -235

petioles, or fruits, cylindrical, $2-3 \mathrm{~mm}$. high ; peridium rupturing at the apex, margin not splitting much, erect, peridial cells, usually seen in face view, broadly lanceolate, $29-40$ by $70-90 \mu$, inner

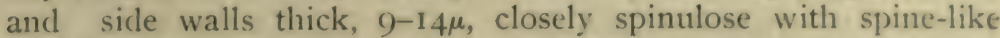
papillae up to $6 \mu$ long, outer wall thinner, about $3 \mu$, sculptured like the inner and side walls but with shorter papillae; aeciospores globoid or broadly ellipsoid, 22-25 by 26-3I $\mu$, wall cinnamon-brown, medium thick, $2-3 \mu$, finely verrucose; pores distinct, $6-8$, scattered.

On Crataegus sp., Boerne, Texas, June 12, 1908, G. G. Hedgcock.

3. Gymnosporangium sp. nov. The chain of circumstances which led up to the detection and final culture of this very interesting species of rust is given with sufficient detail in the introduction to this paper, and need not be repeated. Material collected by Mr. F. D. Kern, June 4, I909, at Leland Mich., on Juniperus horizontalis Moench, was sown, June 5, on one plant of Amelanchier erecta, and two plants of A. canadensis. Numerous pycnia appeared on all three plants, one June $1_{4}$, and the other two June 16. Owing to the fact that the season was well advanced, and the foliage on the Amelanchier plants quite mature. by the time well developed telia could be obtained in the northern habitat, the leaves on all three plants used for cultures ripened and fell before aecia appeared. The field collection of the previous autumn, however, supplied authentic material for study, and the results are not open in the slightest degree to doubt.

It is very gratifying to establish the relationship of the hornlike aecia on Amelanchier, as it is now possible to distribute the three very similar forms, that have heretofore gone under one name, and supposed to belong to one cosmopolitan' species. The three species are: Gym. cornutum, with aecia on Sorbus, common to Europe and America, Gym. Davisii, with aecia on Aronia, known only in America, and the present form with aecia on Amclanchier, also known only from America. The first two. have their telia on the true juniper, while the last has telia on the red cedar. The new form has been studied morphologically by Mr. F. D. Kern, who has drawn up the following description and supplied the name. 


\section{Gymnosporangium corniculans Kern sp. nov.}

O. Pycnia epiphyllous, gregarious, in small groups $0.5^{-1} \mathrm{~mm}$. across, on discolored spots, rather prominent and conspicuous, honey-yellow, becoming blackish, slightly flattened globose, I 30$175 \mu$ in diameter by $130-160 \mu$ high; ostiolar filaments $50-80 \mu$ long.

I. Aecia hypophyllous, crowded in irregular or annular groups, 2-5 mm. across, cylindrical or horn-shaped, acutish at apex, 2-3.5 $\mathrm{mm}$. high; peridium tardily dehiscent by longitudinal slits along the sides, peridial cells usually seen in face view, broadly lanceolate, $16-23$ by $64-96 \mu$, inner and side walls rather thick, $5-7 \mu$, moderately verrucose with oval or roundish papillae and a few elongated papillae interspersed, outer wall thin, I.5-2 $\mu$, smooth; aeciospores globoid, $19-26$ by $23-32 \mu$, wall dark cinnamon-brown, rather thick, $3-4 \mu$, finely verrucose, appearing nearly smooth.

On Amelanchier canadensis (L.) Medic., Burlington, Vt., Sept. 25. I897, W. A. Orton; Fort Spring, W. Va., Sept. 14, I906, J. L. Sheldon; Granville, Mass., Sept. 22, 1800, A. B. Seymour (Seym. \& Earle, Econ. Fungi $27^{a}$ ); Amelanchier erecta Blanch.. Isle Royale, Mich., Aug. 28, 1901, Stuntz \& Allen; Leland, Mich., Sept. 7, 1908, Arthur \& Kern; Amelanchier intermedia Spach, Taughannock Falls, N. Y., Sept. 3, 1908, Whetzel, Wallace \& Reddick.

III. Telia caulicolous, from a perennial mycelium, appearing on irregularly lobed, gall-like excrescences 2-15 mm. or more in diameter, unevenly distributed, often separated by the scars of the sori of previous seasons, conical or cylindrical-acuminate, I. 5-2 $\mathrm{mm}$. in diameter at the base by 3-5 $\mathrm{mm}$. high, dark chestnutbrown; teliospores 2 -celled, ellipsoid, I8-2 I by $35^{-50} \mu$, slightly or not constricted at the septum, slight hyaline thickenings over the germ-pores, wall cinnamon-brown, thin $\mathrm{I}-\mathrm{I} .5 \mu$; pedicel uniform, long; pores $\mathrm{I}-2$ in each cell, near the septum.

On Juniperus horizontalis Moench, Leland, Mich., June 4, I909, F. D. Kern.

4. Gymnosporangium sp. nov.-Among the material collected at Santee Canal, S. C. by Mr. F. D. Kern on March 18, I909, was an abundance of telia on Juniperus virginiana, in part extending along the smaller branches often for a foot or more, and referred to above under unsuccessful cultures, and in part forming rather distinct globoid galls from very small up to a half inch or even more in diameter. It was difficult to tell in the field whether there were two species associated or only the incidental 


\section{Arthur: Cultures of Uredineae in $1909 \quad 237$}

variation of a single species, as both forms bore prominent dark brown telia of quite similar appearance. The cultures, however, settled the question. Sowings were made of the gall-form March 22, on Crataegus punctata giving rise to yellow spots after fifteen days, on which pycnia appeared by April 12, but the leaves matured before aecia could form. Other sowings were made May 14 on Crataegus coccinea and C. cerronis, giving rise to a few belated pycnia on the former, first observed June 14, but on the latter to an abundance of pycnia May 25 and mature aecia October 27.

This fortunate culture adds another species, with life cycle known, to the Atlantic coast rusts of the common red cedar. It does not appear to be represented in herbaria, either in the aecial or telial form, except by some small unnamed fragments. Possibly collections of aecia have been referred to G. globosum, which grows on Crataegus, although the peridia differ in gross appearance. An interesting point is that this species produces cornute aecia, the first to be noticed on Crataegus. The following name and description have been supplied by Mr. Kern, who has also increased the number of aecial hosts by searching in phanerogamic collections.

\section{Gymnosporangium trachysorum Kern, sp. nov.}

O. Pycnia epiphyllous, gregarious, in groups $\mathrm{I}-2 \mathrm{~mm}$. across, prominent, punctiform, orange-yellow becoming brownish-black, globoid, $144-165 \mu$ in diameter by I I $2-128 \mu$ high ; ostiolar filaments 75-90 $\mu$ long.

I. Aecia hypophyllous, rather few in irregular groups $2-5 \mathrm{~mm}$. across, on discolored slightly thickened spots $5^{-10} \mathrm{~mm}$. or more across, cylindrical, $2-4 \mathrm{~mm}$. high, $0.2-0.3 \mathrm{~mm}$. in diameter; peridium remaining horn-like, finally rupturing by longitudinal slits along the sides, peridial cells long and narrow in side view, I 5-19 by $3^{2-90 \mu}$, outer wall thin I. $5^{-2 \mu}$, nearly or quite smooth, inner and side walls moderately thick, $3-6 \mu$, closely spinulose with short spine-like papillae interspersed with lower oval or ridge-like papillae; aeciospores globoid or ellipsoid, $15^{-23}$ by $18-27 \mu$, wall chestnut-brown, rather thick, about $2.5-3 \mu$, very minutely verrucose, appearing almost smooth; pores about 6 , scattered.

On Crataegus Marshallii Egg. (C. apiifolia Michx.) Auburn, Lee Co., Alabama, Nov. 20, 1897, F. S. Earle; Aldenbridge, La., 
Nov. I, I898, Wm. Trelease; Crataegus flavo-carius Ashe, Salisbury, N. C., Sept. I I and 12, 1908, W.W. Eggleston; Crataegus Phaenopyrum (L. f.) Medic. (C. cordata Ait.), Salisbury, N. C., Oct. 7, 1908, Catawba, N. C., Sept. 13 and 14, 1908, $W . W$. Eggleston.

III. Telia cauliculous, from a perennial mycelium, appearing on abruptly fusiform or globoid gall-like enlargements, $0.5^{-1.5}$ $\mathrm{cm}$. in diam. by $0.5-3 \mathrm{~cm}$. long, unevenly disposed, sometimes densely crowded, often separated by the scars of the sori of previous seasons, more or less wedge-shaped, $1.5^{-2} \mathrm{~mm}$. broad by $2-4$ $\mathrm{mm}$. long at base by 6-10 $\mathrm{mm}$. high, surface very rough with irregular warts and ridges, dark chestnut-brown; teliospores 2celled, ellipsoid, I $8-2$ I by $37-45 \mu$, wall cinnamon-brown, medium thin $1.5-2.5 \mu$; pedicel hyaline, very long, uniform; pores 1 or 2 in each cell, near the septum.

On Juniperus zirginiana L., Santee Canal, S. C., March I8, 1909, Frank D. Kern (type): Agricultural College, Miss., April 10, 1893 , S. M. Tracy.

\section{SUMmary.}

The following is a complete list of the successful cultures made during the year 1909. It is divided into two series, species that have previously been grown in cultures and reported by the writer or other investigators, and species whose culture is now reported for the first time.

\section{A. Species Previously Reported.}

I. Puccinia Peckii (DeT.) Kellerm.-Teliospores on Carex lanuginosa Michx. and on C. trichocarpa Muhl., sown on Onagra biennis (L.) Scop.

2. Puccinia Caricis (Schum.) Schröt.-Teliospores on Carer. aristata $\mathrm{R}$. Br., sown on Urtica gracilis Ait.

3. Puccinia universalis Arth.-Teliospores on Carex stenophylla Wahl., sown on Artcmisia dracunculoides Pursh.

4. Puccinia Caricis-Asteris Arth.-Teliospores on Carex festiz'a Dewey, sown on Aster adscendens Rydb.

5. Puccinia subnitens Diet.-Teliospores on Distichlis spicata (L.) Greene, sown on Atriplex hastata L. and Chenopodium album L.

6. Puccinia amphigena Diet.-Teliospores on Calamovilfa longifolia (Hook.) Hack., sown on Smilax hispida Muhl. 
Artilu: Culteres of Ureninear in IgOG * 239

7. Puccinia fra.rinata (Schw.) Arth.-Teliospores on Spartina cynosuroides Willd., sown on Fraxinus lanceolata Borck.

8. Puccinia Phragmitis (Schum.) Körn.-Teliospores on Phragmites communis Trin., sown on Rumex crispus L.

9. Puccinia obliterata Arth.-Teliospores on Agropyron sp., sown on Thalictrum alpinum $\mathrm{L}$.

ı. Puccinia Muhlenbergiae Arth. \& Holw.-Teliospores on Muhlenbergia glomerata Trin., sown on Callirrhoe inzolucrata (T. \& G.) A. Gray.

II. Puccinia Impatientis (Schw.) Arth.-Teliospores on Elymus striatus Willd., sown on Impatiens aurea Muhl., and aeciospores on Impatiens aurea Muhl., sown on Elymus virginicus L., E. canadensis L., and E. striatus Willd.

12. Puccinia poculiformis (Jacq.) Wettst.-Teliospores on Agropyron pseudorepens Scribn. \& Sm., and Sitanion longifolium J. G. Sm., sown on Berberis vulgaris L., and aeciospores on Berberis vulgaris L., sown on Triticum vulgare Vill.

13. Puccinia substerilis E. \& E.-Amphispores on Stipa viridula Trin., sown on same host.

I4. Uromyces Andropogonis Tracy.-Teliospores on Andropogon virginicus L., sown on Viola cucullata Ait.

15. Uromyces Spartinae Farl.-Teliospores on Spartina cynosuroides Willd., sown on Steironema lanceolatum (Walt.) A. Gray and S. ciliatum (L.) Raf.

16. Gymnosporangium globosum Farl.-Teliospores on Juniperus virginiana L., sown on Crataegus coccinea L.

17. Gymnosporangium clazipes C. \& P.-Teliospores on Junipcrus sibirica Burgsd., sown on Amelanchier erecta Blanch., and Crataegus punctata Jacq.

18. Gymnosporangium nidus-aris Thax.-Teliospores on Juniperus virginiana L., sown on Crataegus Pringlei Sarg., and Malus Ioensis (Wood) Britt.

19. Gymnosporangium Betheli Kern.-Teliospores on Juniperus scopulorum Sarg., sown on Crataegus cerronis A. Nels.

20. Gy'mnosporangium cornutum (Pers.) Arth.-Teliospores on Junipcrus sibirica Burgsd., sown on Sorbus americana Marsh. and $S$. Aucuparia L.

21. Gymnosporangium floriforme Thax.-Teliospores on Juniperus zirginiana L., sown on Crataegus coccinea L. 


\section{5}

22. Gymnosporangium exterum Arth. \& Kern.-Teliospores on Juniperus virginiana L., sown on Porteranthus stipulatus (Muhl.) Britt.

23. Calyptospora columnaris (A. \& S.) Kühn.-Teliospores on Vaccinium pennsylvanicum Lam., sown on Abies Fraseri Pursh.

\section{B. Species Reported Now for the First Time.}

I. Puccinia Ceanothi (Ellis \& Kellerm.) Arth.-Teliospores on Andropogon Hallii Hack., sown on Ceanothus americanus L.

2. Gymnosporangium exiguum Kern.-Teliospores on Juniperus virginiana L., sown on Crataegus Pringlei Sarg.

3. Gymnosporangium corniculans Kern.-Teliospores on Juniperus horizontalis Moench, sown on Amelanchier erecta Blanch., and $A$. canadensis (L.) Medic.

4. Gymnosporangium trachysorum Kern.-Teliospores on Juniperus virginiana L., sown on Crataegus punctata Jacq., C. coccinea L., and C. cerronis A. Nels.

Purdue University,

LAFAYETTE, INDIANA. 
(11) 



\section{CULTURES OF UREDINEAE IN IgIO}

\section{J. C. Arthur}

The present article is the eleventh of a series of reports ${ }^{1}$ by the writer upon the culture of plant rusts, beginning in 1899 . Almost uniform progress has been made during the twelve years in the prime purpose of the work, that of experimentally connecting the sporophytic and gametophytic phases of heteroecious rusts, as well as the study of autoecious species and in some cases the detection of races. The work of the year is representative in these several respects. It was under the charge of Miss Irma A. Uhde, a senior student in general science in the University of Iowa, who was recommended by Professor Thomas H. Macbride. Miss Uhde conducted the work with fine insight and untiring patience, securing a notably large number of successful infections. Some of the sowings, particularly those of the cedar rusts were made and the records kept by Dr. F. D. Kern. All the work was done under the auspices of the Indiana Experiment Station, and financed from the Adams fund.

There are some very common American rusts that collectors of culture material are likely to send in considerable abundance every year, such as Puccinia Caricis, P. Peckii, P. angustata and the Aster-Solidago-Erigeron group among the sedge rusts, and $P$. poculiformis, $P$. pustulata, $P$. Andropogonis, $P$. Impatientis and $P$. fraxinata among the grass rusts. These are usually sown, although the life cycle is known, and when time and opportunity permit some tests are made regarding their less known aecial hosts and the possibility of races. While these and similar species take time that could usually be put upon less known forms to better advantage, there is another set of common rusts often sent by collectors, whose life cycle is not known, such as Puccinia emaculata, $P$. Ellisiana, $P$. vexans, and the form on Carex Penn-

${ }^{1}$ See Bot. Gaz. 29: 268-276: 35: 10-23; Jour. Myc. 8: $51-56 ; 10: 8-21$; II : $50-67 ; 12: 11-27 ; 13: 189-205 ; 14: 7-26 ;$ Mycol. I: 225-256; and 2: $213-240$. 
sylvanica, which consume time with no more profit. They have been repeatedly sown, but for want of careful field observations regarding proximity of aecia, little advance is made.

Those who assisted in the work with culture material, and often with valuable suggestions, are named with special gratitude, for to them is due in considerable degree whatever of value has come from the year's labors. Mr. E. Bethel, Denver, Colo., sent I23 collections, by far the largest number contributed by one person in any year since the work began. Messrs. W. P. Fraser, Pictou, Nova Scotia, J. F. Brenckle, Kulm, N. D., and W. H. Long, Washington, D. C., sent between 30 and 40 collections each, while much smaller numbers were sent by Messrs. E. Bartholomew, Stockton, Kans., J. M. Bates, Red Cloud, Neb., H. S. Coe, Ames, Iowa, J. J. Davis, Racine, Wis., A. C. Dillman, Washington, D. C., H. S. Fawcett, Gainesville, Fla., A. O. Garrett, Salt Lake City, Utah, R. A. Harper, Madison, Wis., E. W. D. Holway, Minneapolis, Minn., Haven Metcalf, Washington, D. C., A. J. Norman, College Park, Md., E. W. Olive, Brookings, S. D., J. B. Pollock, Ann Arbor, Mich., Donald Reddick, R. E. Stone, and H. H. Whetzel, all three of Ithaca, N. Y., Guy West Wilson, Fayette, Iowa, and by Misses Louise Falk, Boulder, Colo., and Miriam Turner, Isle au Haut, Me. Many living plants were received from a number of botanists to whom requeșts had been sent for suitable specimens on which to make sowings of particular rusts. To all these and to others who assisted in the year's investigations the writer extends his heartiest thanks.

During the present season 294 collections of material with resting spores and 25 collections with active spores were employed, from which 987 drop cultures were made to test the germinating condition of the spores. Out of the 294 collections with resting spores $\mathrm{I} 34$ failed to germinate, leaving 160 collections available for experimental tests, this being a far larger number than in any previous year. Altogether about 400 sowings were made, using a great variety of hosts growing in pots in the greenhouse, and 75 infections obtained. The most important conclusions derived from a study of the results are given in the following paragraphs.

Negative ReSUlts.-A number of collections giving good ger- 


\section{Arthur: Cultures of Uredineae in igid 789}

mination of the spores were sown on plants in the hope of discovering the alternate host but without securing infection. The following are recorded to serve for reference in future studies.

I. Puccinia on Carex Pennsylvanica L., collected at Kulm, N. D., by Dr. J. F. Brenckle, was sown on Laciniaria punctata (on 4 different dates), L. spicata, Dirca palustris (2 dates), and Meriolix serrulata ( 2 dates), with no infection. In preceding years this rust was sown on forty other species of hosts without infection. ${ }^{2}$

2. Puccinia on Carex tenella Schk., collected at Pictou, Nova Scotia, by Professor W. P. Fraser, was sown on Phryma leptostachya (on 2 different dates), with no infection. In I909 a similar collection was sown on six other species of hosts with no results. $^{3}$

3. Puccinia on Carex stellulata Good., collected by the writer at Isle au Haut, Me., was sown on Aster Drummondii, Solidago canadensis, and Ribes Cynosbati, with no infection.

4. Puccinia on Carex trisperma Dewey, collected at Pictou, Nova Scotia, by Professor W. P. Fraser, was sown on Myrica cerifera, Apocynum cannabinum, Senecio Douglasii, and Solidago caesia, with no infection.

5. Puccinia on Carex arctata Boott, collected at Pictou, Nova Scotia, by Professor W. P. Fraser, was sown on Lysimachia terrestris, L. quadrifolia, Chelone glabra (on 2 different dates), $R$ udbeckia laciniata, and $R$. triloba, with no infection.

6. Puccinia perminuta Arth., on Agrostis hyemalis (Walt.) B. S. P., collected by the writer at Isle au Haut, Me., was sown on Orchis spectabilis and Actaea alba, with no infection. Another collection on A. perennans (Walt.) Tuckerm., collected at Pictou, Nova Scotia, by Professor W. P. Fraser, was sown on Aquilegia canadensis, Thalictrum dioicum, Caulophyllum thalictroides, Anemonella thalictroides, and Isopyrum biternatum, with no infection.

7. Puccinia Ellisiana Thüm., on Andropogon scoparius Michx., collected by Dr. J. F. Brenckle, at Kulm, N. D., was

${ }^{2}$ See Jour. Myc. I0: 10. 1904; 11: 51. 1905; 12: 12. 1906: 13: 191. 1907; 14: 9. I908; and Mycol. I: 229. 1909.

See Mycol. I: 218. I9ro. 
sown on Boehmeria cylindrica, Uvularia grandiflora, Myrica cerifera, Lysimachia quadrifolia, Thalictrum polygamum, and Laciniaria spicata, with no infection. Similar material from Colorado, Nebraska, Delaware and North Carolina was sown in previous seasons on thirty five other species of hosts. ${ }^{4}$

8. Puccinia Schedonnardi K. \& S., on Schedonnardus paniculatus (Nutt.) Trel., collected by Mr. E. Bethel, at Westminster, Colo., was sown on Delphinium formosum, Xanthoxylum americanum, Symphoricarpos pauciflorus, Hydrophyllum virginicum, H. capitatum, Onosmodium occidentale, Petalostemon purpureus, Amorpha nana, Boltonia asteroides, Grindelia squarrosa, Rudbeckia triloba, Laciniaria punctata, Solidago rigida, and Arnica sp., with no infection. This collection possessed clean and well developed sori, and gave strong germination. Similar material in former years was sown on fifteen other species of hosts. ${ }^{5}$

9. Puccinia virgata Ellis \& Ev., on Chrysopogon avenaceus (Michx.) Benth., collected by Mr. W. H. Long at El Reno, Okla., was sown on Dirca palustris, Xanthoxylum americanum, Boehmeria cylindrica, Apios Apios, Petalostemon purpureus, and Mimulus ringens, with no infection. Similar material from Nebraska and North Carolina was sown in previous years on nine other species of hosts. ${ }^{\circ}$

10. Puccinia tosta Arth., on Sporobolus asperifolius Nees \& Meyen, collected by Dr. J. F. Brenckle at Kulm, N. D., was sown on Lepargyraca canadensis, Dirca palustris, Symphoricarpos racemosus, Apocynum cannabinum, Delphinium formosum, Polemonium reptans, Laciniaria punctata, Aster paniculatus, and Arnica sp., with no infection.

Another collection on same host, made by Mr. E. Bethel at Denver, Colo., was sown on Symphoricarpos racemosus, Lepargyraea canadensis, Phacelia heterophylla, Hydrophyllum virginicum, Lithospermum canescens, Amorpha fruticosa, Arabis Holboellii, and Sidalcea oregana, with no infection. Similar material was sown in previous years on ten other species of hosts. ${ }^{7}$

4 See Jour. Myc, 14: 10. 1908; Mycol. 1: 231. 1909; 2: 220. 1910.

${ }^{8}$ See Bot. Gaz. 35 : II. 1903 ; Jour. Myc. I3 : 192. I907; I4: II. 1908; and Mycol. I: 231. 1909.

- See Jour. Myc. 14: 10. 1908; and Mycol. 2: 219. 1910.

'Tee Jour. Myc. 10: 10. 1904; and 12: 12. 1906. 


\section{Arthur: Cultures of Uredineae in ig fo}

II. Puccinin on Phalaris arundinacea L., collected by Dr. E. W. Olive, at Brookings, S. D., was sown on Polygonatum commutatum, Vagncra stellata, Convallaria majalis, Uvularia grandiflora, and Trillium cernuum, with no infection.

12. Puccinia Disticilinis E. \& E., on Spartina sp., collected at Kulm, N. D., by Dr. J. F. Brenckle, was sown on Lithospermum canescens (on 2 different dates), Onosmodium hispidissimum, Lepargyraea canadensis (2 dates), Elaeagnus angustifolia, Dirca palustris, Fra.rinus lanceolata, Symphoricarpos racemosus, Aesculus glabra, Apocynum cannabinum, Hydrophyllum capitatum, Macrocaly.x Ny'ctelea, Isopyrum biternatum, Amorpha nana, Cassia chamaccrista, Petalostemon purpureus, Physalis sp., Ambrosia trifida, and Carduus Flodmanii, with no infection. A year ago the same rust was sown on three other hosts without results.

13. Puccinia Anthoxanthi Fckl., on Anthoxanthum odoratum L., collected by Professor W. P. Fraser, at Pictou, Nova Scotia, was sown on Berberis vulgaris, Myrica cerifera, Apocynum cannabinum, Tissa canadensis, Senecio lugens, and Rudbeckia triloba, with no infection.

14. Puccinia on Trisetum majus (Vasey) Rydb. having covered telia and coronate teliospores, simulating $P$. Rhamni, collected in the foothills of Colorado, by Mr. E. Bethel, was sown on Rhamnus alnifolia from one collection, and on Rhamnus cathartica from another. A similar collection from Golden, Colo., with same data, was sown on the two sets of Rhammus, while another collection from Boulder, Colo., was sown on Mahonia Aquifolium and Arabis Holboellii. In each instance there was no infection.

15. Puccinia montanensis Ellis, on Elymus canadensis L. collected by Mr. E. Bethel, at Colorado Springs, Colo., was sown on Clematis virginiana (on 2 different dates), Viorna Douglasii (2 dates), Impatiens aurea, Delphinium scaposum, Viola septentrionalis, Arabis Holboellii, Amorpha nana, Senecio Douglasii, and Arnica sp., with no infection. In 1907 what is thought to be the same rust was sown four times on Delphinium tricorne without result. ${ }^{9}$

See Mycol. 2: 219. 19ro.

-See Jour. Myc. 14: 11. 1908. 
i6. Uromyces Eleocharidis Arth., on Eleocharis palustris (L.) R. \& S., collected by Dr. E. W. Olive, at Brookings, S. D., was sown on Laciniaria spicata, L. scariosa, Eupatorium serotinum, Polygala Senega, Hydrophyllum virginicum, Amorpha fruticosa, Symphoricarpos racemosus, Lepargyraea canadensis, and Dirca palustris, with no infection. In 1906 the same rust was sown on five other species of hosts without results. ${ }^{10}$

I7. Uromyces Spartinae Farl,, on Spartina Michauxiana A. S. Hitch. (usually listed as S. cynosuroides), collected by Professor W. P. Fraser, at Pictou, Nova Scotia, was sown on Steironema ciliatum (on 2 different dates), Polemonium reptans, Phlox divaricata, and Tissa canadensis, with no infection.

Another collection from the same collector and place, but on S. patens (Ait.) Muhl., was sown on Steironema ciliatum (2 dates), Polemonium reptans, and Lysimachia terrestris, with no infection.

It is evident from the present repeated inability to infect Steironema with Spartina rust from the salt marshes of the sea coast, supposedly the same species as in the interior, ${ }^{11}$ that the status of this rust, or group of rusts, is not yet fully known. Either we are dealing with more species than heretofore recognized, or there are biological races yet undetermined.

18. Uromyces Peckianus Farl., on Distichlis spicata (L.) Greene, collected by Professor W. P. Fraser, at Pictou, Nova Scotia, was sown on Tissa canadensis (on 2 different dates), Mimulus ringens, and Rudbeckia laciniata, with no infection.

I9. URomyces GRAMINICOLA Burr., on Panicum virgatum L., collected by Mr. W. H. Long, at El Reno, Okla., was sown on Dirca palustris, Apios tuberosa, and Boltonia asteroides, with no infection. Another collection on the same host sent by Mr. E. Bartholomew from Stockton, Kans., was sown on Apios tuberosa, Petalostemon purpureus, Cassia chamaecrista, Aesculus glabra, Apocynum cannabinum, and Laciniaria spicata, with no infection.

The same rust has been sown on eleven other species of hosts in previous years. ${ }^{12}$

${ }^{10}$ See Jour. Myc. 13: 193. 1907.

${ }^{11}$ For a statement regarding Uromyces on Spartina see Mycol. 2: 221. r9ro.

${ }^{12}$ See Jour. Myc. 12: 13. 1906; Mycol. 1: 232. 1909; 2: 220. 1910. 


\section{2 \\ Artiur: Cultures of Uredineae in I9IO 13}

20. Uromycis Sporoboli E. \& E., on Sporobolus neglectus Nash, collected by Dr. E. W. Olive, at Brookings, S. D., was sown on Lepargyraea canadensis, Elaeagnus angustifolia, Amorpha nana, Erigeron annuus (on two different dates), and Arnica sp., with no infection. ${ }^{18}$

2r. AECIDIUM on Euphorbia commutata Engelm. was obtained in the vicinity of Lafayette, Ind., by Messrs. F. D. Kern and T. Billings. The living plants were placed in pots and continued to flourish. They bore aecia in all stages of maturity. These plants were adjusted in a moist chamber over the following hosts, so that aeciospores fell spontaneously upon the young leaves: Astragalus canadensis, Pisum sativum, Lathyrus palustris, Medicago sativa, and Trifolium pratense. No infection was obtained.

Successful cultures supplementing PRevious work.-The facts derived by growing the following species of rusts supplement those obtained from previous cultures in this series or from cultures recorded by other American gr Eypopean investigators.

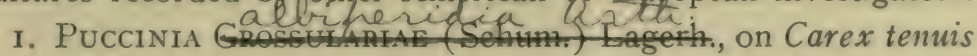
Rudge, collected at Pictou, Nova Scotia, by Professor W. P. Fraser, was sown April 7 on Erigeron annuus, Solidago canadensis, Aster paniculatus and Ribes Cynosbati, with infection only on the last, ${ }^{14}$ showing pycnia April 16 , and aecia April 25. Similar material obtained by the writer at Isle au Haute, Me., was sown on the same hosts, but omitting Erigeron, and with similar results.

A collection on Carex pallescens L., made by Professor W. P. Fraser at Pictou, Nova Scotia, the previous fall, was sown April 8 on Erigeron annuus, Solidago canadensis, Aster paniculatus and Ribes Cynosbati, with infection only on the last, showing abundant pycnia April I6, and aecia April 22. A similar collection, made by Prof. Fraser in the spring, was sown April 18, without infection, on Lysimachia terrestris, Lactuca scariola, Rudbeckia laciniata, Polygala Senega and Apocynum cannabinum. Two days earlier it was sown on Ribes Cynosbati, resulting in good infection, showing pycnia April 27, and aecia May 3 .

"See Bot. Gaz. 35 : 11. 1903.

${ }^{34}$ For similar negative results see Mycol, 2: 218. 1910. 
The Care. rusts having aecia on Ribes are yet imperfectly known. My own culture work began in I90I, and owing to the remarkably pale aecia produced, the form in hand at the time was named Puccinia albiperidia. Since then many cultures have been made, and the status of the species has received considerable attention, but not until recently has any well marked morphological characters been discovered. Present studies indicate that $P$. albiperidia is a species worthy of being maintained. Beside the more or less pale aecia it possesses one basal pore in the urediniospore.

It is curious to note that the only other species of monocotyledonous rust known with a single basal pore in the urediniospore, Uromyces uniporulus Kern, is also on Carex. When published it had only been found in Connecticut on C. tenuis. Since then it has been detected in Wisconsin on C. gracillima. These are also the hosts of $P$. albiperidia, together with $C$. pallescens and $C$. pubescens. Comparing the spores, it appears that the urediniospores of the Puccinia and of the Uromy'ces not only agree in the pore characters, but also as to form, size and color, i. e., in all morphological characters. The teliospores are also alike except in number of cells, and in the consequent length. If the sori of the Puccinia often contained many one-celled teliospores, and the sori of the Uromyces often had a few two-celled spores, $U$. uniporulus might be considered a mere mesoporic form of $P$. albiperidia. But such does not appear to be the case. However, while in the present state of uredinological taxonomy the two forms are to be maintained as distinct species belonging to different genera, yet $U$. uniporulus is doubtless only a morphological race of $P$. albiperidia. Cultures of $P$. albiperidia were made in I90I, 1903 and $1904 .{ }^{15}$ No cultures have yet been made of $U$. uniporulus, but it probably has aecia on Ribes.

The far more common and widely distributed species, for which I am making the name Puccinia Grossulariae serve, has more deeply colored aecia and three equatorial pores in the urediniospore. I am inclined to think that this is the common gooseberry-Carex rust of this country and Europe, but I am not able at present to define its limits, neither can I say whether the

${ }^{15}$ See Jour. Myc. 8: 53. $1902 ; 10: 11.1904$; and in part 11 : 58. 1905. 


\section{4 \\ Arthur: Cultures of Uredineae in I9 10 S i 15}

currant-Carex rusts belong here or not. My previous cultures ${ }^{16}$ of this form have been reported under the name $P$. albiperidia, and confused with that species.

2. Puccinia Peckir (DeT.) Kellerm., on Carex lanuginosa Michx., collected at Kulm, N. D., by Dr. J. F. Brenckle, was sown April 7 on Onagra biennis and Meriolix serrulata, with no infection on the latter, but with abundant pycnia on the former April I6, and aecia April 25.

Another collection on Carex trichocarpa Muhl., made at Carmel, Ind., by Messirs. F. D. Kern and A. G. Johnson, was sown April 13 on plants of the same two species of hosts with similar results. There was no infection of the Meriolix, but abundance of pycnia showed on the Onagra April 23, and aecia May 5. A duplicate sowing was made May II, which gave a few pycnia on the Meriolix, but no aecia developed, while on the Onagra abundance of pycnia appeared May 19, and aecia May 27. ${ }^{17}$

In previous years this species of rust has been grown on Onagra biennis and Gaura biennis, the two hosts being very similar in vegetative structure. Aecia have been gathered in the field on a number of related hosts with less similarity in vegetative structure, such as Meriolix, but heretofore no cultural studies have been made. The present attempt may be interpreted as indicating that certain outlying hosts are infected only under exceptionally favorable circumstances, or that there exist more or less well marked races.

3. Puccinta Caricis-Solidaginis Arth., on Carex scoparia Schk., collected by the writer at Isle au Haut, Me., was sown April 20, on Euthamia graminifolia (Solidago lanceolata) and Solidago rugosa, with infection only on the former, abundance of pycnia showing April 30, and aecia May 9. Another sowing was made June Io on the same two hosts, and on S. canadensis, $S$. nemoralis, Doellingeria umbellata and Aster paniculatus, with

${ }^{16}$ See Jour. Myc. II : 58. 1905 (in part); 12: 14. 1906; 13:196. 1907; and 14: 13.1908.

${ }^{17}$ For previous cultures see Bot. Gaz. 35 : 13. 1903; Jour. Myc. 8: 52 . 1902 ; II : 58. 1905; 12: 15. 1906; 13: 195. 1907; Mycol. I: 233.1909; and 2: 222. 1910. 
infection only on the Euthamia, showing pycnia June I8, and aecia July $5 \cdot{ }^{18}$

All the hosts used in the trial are common in the vicinity where the telial material was obtained and bear aecia. It is highly probable that the aecial forms occurring on Solidago, Aster, Erigeron, Euthamia, and possibly Doellingeria, belong to one species made up of fairly well defined races. The form on Euthamia appears from present data to constitute a race distinct from that on Solidago, but is here included under the same name.

4. Puccinia Caricis-Asteris Arth., on Carex festiz'a Dewey collected by Mr. E. Bethel, at Tolland, Colo., 9,00o feet altitude, was sown April 13, on Aster adscendens Lindl. (A. Treedyi Rydb.), and the day following on Onagra biennis, with no infection on the latter and abundant infection on the former, giving pycnia April 27, and aecia May 2. Another collection with same data was sown on Aster adscendens April 9, and again on May 4, only the latter being effective, giving pycnia in abundance May I4, and aecia May 2I. ${ }^{10}$

5. Peccinia Opizir Bubák, on Carex siccata Dewey, collected by Dr. J. F. Brenckle, at Kulm, N. D., was sown as follows:

April 9, Lactuca canadensis: pycnia April 16, aecia April 25.

April 9, Lactuca sativa: pycnia April 25, aecia May 2.

April 19, Lactuca canadensis: pycnia April 30, aecia none.

April r9, Lactuca sativa: pycnia May 6, aecia none.

In the sowings on both dates the infection developed more slowly and less abundantly on the garden lettuce ( $L$. sativa), than on the wild form. In both of the late sowings the aecia failed to appear, because the leaves matured too soon and died. ${ }^{20}$

6. Puccinia universalis Arth., on Carex stenophylla Wahl., collected by Mr. E. Bethel, at Boulder, Colo., was sown April I9, on Artemisia dracunculoides, giving abundance of pycnia April 29, and aecia May $3 \cdot{ }^{21}$

\footnotetext{
${ }^{18}$ For previous cultures see Bot. Gaz. 35: 21. 1903; Jour. Myc. 12: 15. 1906; and Mycol. I: 233. I909.

${ }^{10}$ For previous cultures see Bot. Gaz. 35 : 15. I903; Jour. Myc. 8: 54. 1902 ; 14: 13. 1908; and Mycol. 2 : 224. 1910.

${ }^{20}$ For previous culture from an undetermined Carex see Jour. Myc. 13 : 194. 1907.

${ }^{20}$ For previous cultures see Jour. Myc. 14: 21. I908; and Mycol: 2: 224 . 1910.
} 


\section{Arthur: Cultures of Uredineae in igio 186}

7. Puccinia Caricis (Schum.) Schröt., on Carex aristata R. Br., collected by Dr. J. F. Brenckle, at Kulm, N. D., was sown April 7, on Urtica gracilis and Boehmeria cylindrica, with infection only on the former, giving pycnia April I3, and aecia April 19.

Another collection on Care. stricta Lam., made in the vicinity of Lafayette, Ind., by Mr. A. G. Johnson, was sown April r3, on the same two hosts, producing infection only on Urtica gracilis, giving pycnia April 22, and aecia April 27. Similar results were obtained in previous years. ${ }^{22}$

8. Puccinia angustata Peck, on Scirpus atrovirens Muhl., collected by Messrs. F. D. Kern and A. G. Johnson, at Carmel, Ind., was sown April 7, on Lycopus americanus, giving pycnia April 16, and aecia April 22. Another similar collection made by Mr. A. G. Johnson near Lafayette, Ind., was sown on same host April I3, giving pycnia April 25, and aecia May I. ${ }^{23}$

9. Puccinia Andropogonis Schw., on Andropogon virginicus L., collected at Clarendon, W. Va., by Mr. W. H. Long, was sown May 13, on Pentstemon hirsutus, giving pycnia May 23, and aecia June 7. Another collection on A. scoparius Michx., made at Boulder, Colo., by Mr. E. Bethel, was sown May 12 on Comandra umbellata and Pentstemon alpinus, with infection only on the latter, and not abundant, pycnia and aecia not being observed until May 3 I $^{24}$

io. Puccinia pustulata (Curt.) Arth., on Andropogon furcatus Muhl., collected at Plainview, Colo., by Mr. E. Bethel, was sown April 13, on Comandra umbellata and Pentstemon barbatus. giving rise to infection only on the former, showing pycnia April 27, and aecia May 9. Another collection by Mr. Bethel from Colorado on Andropogon sp., was sown May I2 on Comandra umbellata and Pentstemon alpinus, with infection only on the former, giving pycnia in abundance May 20, and aecia May $3{ }^{1 .}{ }^{25}$

\footnotetext{
${ }^{22}$ For previous cultures see Bot. Gaz. 29: 270. 1900; 35: 16. 1903; Jour. Myc. 8: 52.1902; 12: 15. 1906; 14: 14. 1908; and Mycol. 2: 223. 1910.

${ }^{23}$ For previous cultures see Bot. Gaz. 29: 273. 1900; Jour. Myc. 8: 53. 1902; 11: 58. I905; 13:196. 1907; 14: 14. 1908; and Mycol. 1: 234. 1909.

${ }^{24}$ For previous cultures see Bot. Gaz. 29: 272. 1900; Jour. Myc. 10: Ir. 1904; and 13: 197. 1907.

${ }^{25}$ For previous cultures see Jour. Myc. 10: 17. 1904; and 12: 16.1906.
} 
II. Puccinia amphigena Diet., on Calamovilfa longifolia (Hook.) Hack., collected by Dr. J. F. Brenckle, at Kulm, N. D., was sown April 25, on Smilax hispida, giving rise to pycnia in abundance May 2, and aecia May ${ }^{14} .{ }^{26}$

i2. Puccinia Muhlenbergiae Arth. \& Holw., on Muhlenbergia racemosa (Michx.) B. S. P., collected by Dr. J. F. Brenckle, at Kulm, N. D., was sown May 6, on Hibiscus militaris, Nupaea dioica and Callirrhoe involucrata, with infection only on the last, giving abundance of pycnia that were first seen May 23, and aecia May $27 .{ }^{27}$ Another collection of the rust on M. gracilis, sent by Mr. E. Bethel, from the foothills of Colorado, was sown on the same three hosts, with no infection. Still a third collection, on $M$. racemosa, sent by Mr. E. Bartholomew from Stockton, Kans., was sown May II, on Hibiscus militaris and Althaea rosea, without infection.

13. Puccinia Rinami (Pers.) Wettst., on Calamagrostis canadensis (Michx.) Beauv., collected by Professor W. P. Fraser, at Pictou, Nova Scotia, was sown May 26, on Rhamnus alnifolia, giving a strong infection, pycnia showing June 6, and aecia June Io. The only previous cultures in the series were made with aeciospores. ${ }^{28}$

14. Puccinia poculiformis (Jacq.) Wettst., on Agropyron tenerum Vasey, collected by Mr. E. Bethel, at Boulder, Colo., was sown April 25, on Berberis vulgaris, giving pycnia May 2, and aecia May 14. Another collection by Mr. Bethel, on Sitanion longifolium J. G. Sm., made at Eldorado Springs, Colo., was sown May 3, on Berberis vulgaris, giving pycnia May I4, and aecia May 26. Still another collection on Agrostis alba L., made by the writer at Isle au Haut, Me., was sown April 19, on Berberis vulgaris, giving pycnia April 29, and aecia May $9 .{ }^{29}$

I5. Puccinia subnitens Diet., on Distichlis spicata (L.) Greene, collected by Dr. J. F. Brenckle, at Kulm, N. D., was sown May 4, on Chenopodium album, Monolepis Nuttalliana, and Cory-

${ }^{28}$ For previous cultures see Bot. Gaz. 35 : 20. 1903; Jour. Myc. 10: I I. 1904; 12: 16. 1906; 14: 15. 1908; and Mycol. 2: 225. 1910.

${ }^{27}$ For previous cultures see Mycol. I: 25I. I909; and 2: 226. 1910.

${ }^{28}$ See Jour. Myc. II : 58. I905.

${ }^{20}$ For previous cultures see Jour. Myc. 8: 53. I902; II : 57. 1905; 12: 17. 1906; 13: 198. 1907; 14: 16. I908; and Mycol. 2: 227. 1910. 
dalis aurea, with infection only on the first, giving numerous pycnia May 16, and aecia May 21. Another sowing was made May 25, on Chenopodium album, Monolepis Nuttalliana, Corydalis sempervirens, and Tissa canadensis, and again infection was only obtained on the first, giving pycnia June 5 , and aecia June I6. These attempts add nothing materially to previous knowledge. ${ }^{30}$

i6. Puccinia Jamesiana (Peck) Arth., on Atheropogon curtipendulus (Michx.) Fourn., collected by Mr. W. H. Long, at Amarillo, Texas, was sown April 19, on Asclepias syriaca, giving pycnia May 3, and aecia May 9. Previous cultures were also made with Texan material sent by Mr. Long. ${ }^{31}$

I7. Puccinia Seymourinna Arth., on Spartina Michauxiana A. S. Hitch, collected by Mr. W. H. Long, at El Reno, Okla., was sown June 3 , on Cephalanthus occidentalis, giving numerous pycnia June II, and aecia June $24 \cdot{ }^{32}$

I8. Puccinia Stipae Arth., on Stipa spartea Trin., collected by Dr. E. W. Olive, at Brookings, S. D., was sown May Io, on Aster ericoides and $A$. Novae-Angliae, giving pycnia in both cases May 19, without developing aecia on $A$. ericoides, but giving aecia on A. Novae-Angliae May 26.

Another collection made by the writer on the same host, at Spirit Lake, Iowa, was sown April 28, on Aster multiflorus, giving pycnia May 6, and aecia May I7. A second sowing was made May 6, on Aster Novae-Angliae, with pycnia May I6, and aecia May 23; on $A$. multiflorus, with pycnia May I7, and aecia May 23; on Solidago canadensis, with pycnia May 24, and aecia June 6; and on Grindelia squarrosa, without infection.

Another collection made by Mr. E. Bethel, at Golden, Colo., on Stipa sp., was sown April 22, on Aster Novae-Angliae, with pycnia May 2, and aecia May 16, on Grindelia squarrosa, with pycnia May 2, and aecia May I6, and on the following hosts without infection: Aster ericoides, A. multiflorus, Solidago cana-

${ }^{20}$ For previous cultures see Bot. Gaz. 35: 19. 1903; Jour. Myc. 11 : 54.1905 ; 12: 16. 1906; 13: 197. 1907; 14: 15. 1908; Mycol. I: 234. I909; and 2: 225a 1910.

${ }^{21}$ For previous cultures see Bot. Gaz. 35: 18. 1903.

${ }^{32}$ For previous cultures see Jour. Myc. 12: 24. 1906; and Mycol. 1: 236; 1009. 
densis, Arnica sp., Boltonia asteroides, Laciniaria scariosa, Symphoricarpos racemosus, and Hydrophyllum virginicum.

Still another collection of what appears to be the same species of rust was collected on Koeleria cristata (L.) Pers., by Miss Louise M. Falk, at Boulder Colo., and sown April 27, on Senecio lugens, Grindelia squarrosa, Symphoricarpos racemosus, Hydrophyllum virginicum, and Arabis Holboellii, with infection only on the first, which showed pycnia May I4, and aecia May 19.

The aecia on the several hosts, thus produced, correspond in structure, and are peculiar in having evanescent peridia, the spores being retained by the surrounding tissues of the hypertrophied leaf. The striking appearance of the aecial groups suggested one of the early synonyms: Accidium sclerothecioides Ellis \& Ev. These cultures, although still lacking in completeness, have enabled us to bring together a number of uncertain forms with a considerable degree of assurance, and to extend both aecial and telial hosts.

19. Puccinia argentata (Schultz) Wint. At my request Professor Guy West Wilson, of Fayette, Iowa, made a somewhat trying excursion to Decorah, Iowa, and with the aid of directions supplied by Professor E. W. D. Holway, who resided there for many years, obtained living plants of Adoxa Moschatellina L., bearing aecia, which were potted and thrived. Two sowings were made April 18, by suspending the plants of Adoxa bearing aecia over plants of Impatiens aurea. 'In both instances a great abundance of urediniospores began to appear May 2. Again on April 2I, two more similar sowings were made on other plants of Impatiens, and an equal abundance of urediniospores appeared May 3. These were followed on all four plants by an unusual abundance of teliospores, the record being made June 6 , although they first appeared somewhat earlier.

The aecia on Adoxa, which are of limited distribution in America, early attracted the writer's attention, and as early as $1883^{33}$ a first attempt was made toward solving their life history. Since the cultures of Bubák ${ }^{34}$ proved that the European form on Adoxa was the aecial stage of telia on Impatiens, I have attempted to

Bot. Gaz. 10: 369 . 1885 .

"Centr. Bakt. 10 : 574. 1903. 
secure American material for cultures, and the ample success when finally obtained is most gratifying. The American and European collections of this interesting heteroecious rust appear alike, and the present cultures show them to be identical.

20. Puccinia Absinthir DC., on a densely canescent species of Artemisia, collected by Mr. E. Bethel, at Boulder, Colo., was sown April 20, on A. dracunculoides, giving pycnia May 2, and uredinia May 20, thrus confirming the previous cultures of two years ago. ${ }^{\text {ss }}$

21. UROMyCes PERIgynius Halst., on Carex intumescens Rudge, collected by Professor W. P. Fraser, at Pictou, Nova Scotia, was sown April 2I, on Solidago nemoralis, again April 26, on S. canadensis, on May I3, on both S. nemoralis and S. canadensis, and also on Aster paniculatus, and finally May I4, on Tissa canadensis and Artemisia ludoviciana. Quite unexpectedly the only sowing producing infection was on Aster, giving pycnia May 19, and aecia May 3r, both abundantly developed.

Another collection apparently of the same rust, sent by Professor Fraser, on Carex deflexa Hornem., was sown May 28, on Solidago rugosa, S. canadensis and Aster Drummondii, with infection only on the first, giving abundance of pycnia June 4, and aecia June 16.

A collection on Carex deflexa, collected by the writer at Isle au Haut, Me., was sown May i3, on Solidago rugosa, S. nemoralis, and Aster ericoides. On S. rugosa numerous pycnia appeared May 20, and aecia May 3I, but S. nemoralis remained free. The Aster, moreover, showed pycnia May 24, and aecia June 6, but they were not numerous and grew slowly. Solidago rugosa has been taken with aecia in the telial vicinity, but 4 ster ericoides does not grow there neither does any closely related species of 4 Aster.

Considerable study has been given to the species of Uromyces on Care $x$ since the initial and only culture ${ }^{86}$ in 1903 . Some of the conclusions may be briefly stated, without giving the steps by which they were reached. We are doubtless dealing with races, more or less well defined, parallel with the races of the Pucciniagroup, which latter goes under several names, two being given

${ }^{25}$ See Mycol. I : 243. 1909.

se Jour. Myc. 10: 15. 1904. 
above under nos. 3 and 4, and which have aecia on Aster, Solidago, Euthamia, Erigeron, and close relatives. As the aecia and uredinia of the two groups, one under the genus Puccinia and the other under Uromyces, are indistinguishable, and as the teliospores of the Uromyces agree with the one-celled spores of the Puccinia, and also with the two-celled spores in all characters except number of cells and consequent length, the former doubtless are morphological races of the latter. Relationship could be shown better by putting all of these forms under one specific name, and designating the several races by varietal names. But in the present state of taxonomy of the rusts it is more convenient to dispose of them under the two genera: Puccinia and Uromyces.

The collection on Carex intumescens used in the culture is in all respects identical with the type collection of Uromyces perigy'nius, which was also on $C$. intumescens, but in the latter the large green perigynia also bore sori as well as the leaves, which unusual but incidental fact suggested the name. The similarity of this species with the form having aecia on Solidago was pointed out in $1903,{ }^{37}$ but for precautionary reasons it was thought best at that time to give the latter a separate name, $U$. Solidagini-Caricis Arth. This name now becomes a synonym of the former, or may be used to indicate the biological race with aecia on Solidago. The type host of this form has been determined as $C$. deflexa, and not $C$. varia as originally stated.

It is further probable that the form on Carex scoparia bearing the name $U$. caricina Peck, which often shows larger spores, should be referred to $U$. perigynius, the last being the oldest name of the three. A collection of this on C. scoparia was sent by Professor Fraser, from Pictou, Nova Scotia, and sown on Lysimachia terrestris, without infection. Its possible relation to the AsterSolidago group did not come to mind soon enough to put the matter to a test.

22. Uromyces Junci (Desm.) Tul., on Juncus balticus Willd. collected at Kulm, N. Dak., by Dr. J. F. Brenckle was sown April I4 on Carduns Flodmanii, Arnica sp., Grindelia squarrosa, Ambrosia trifida, and Sidalcea oregana, with infection only upon the first, showing pycnia April 29, and aecia May 4. Another sowing ${ }^{n}$ L. c. 


\section{Arthur: Cultures of Uredineae in igio $1922_{2}$}

May 10 on Carduus Flodmanii produced pycnia May 19 and aecia June 5. Another collection from the same place but taken at a different date was sown May 19 on Carduus Flodmanii, showing pycnia May 28 and aecia June 5. Three other collections of what appears to be the same rust on the same.host, also sent from Kulm, N. Dak., by Dr. Brenckle but collected at different times were sown on Carduus Flodmanii (various dates), and one of these was also sown upon eighteen other species of hosts, all with no infection. Still another collection on J. balticus from Granby, Colo., sent by Mr. E. Bethel was sown on Carduus Flodmanii without infection.

The results here given appear to support the suggestion made in the last report ${ }^{38}$ that this species is composed of races. The failure to infect Pulicaria with American material, as there stated, seems to indicate that American and European forms represent different races. The failure to infect Carduus with some of the sowings was also doubtless due to the existence of races. Mr. Bethel has since suggested that his collection from Granby is probably connected with aecia on Arnica, and both Mr. Bethel and Dr. Brenckle are of the opinion that there is a form of this species with aecia on Ambrosia psilostachy'a.

23. Uromyces Astragali Sacc., on Aragallus Lamberti (Pursh) Greene (Oxytropis Lamberti Pursh), collected by Mr. E. Bethel at Leyden, Colo., was sown on Euphorbia Cyparissias, without result.

A collection bearing uredinia (Uredo Oxytropi Peck) on Aragallus Lamberti (Pursh) Greene, sent by Mr. Bethel from Boulder, Colo., was sown September 30, on Astragalus carolinianus, giving rise to uredinia that were first noticed October 22.

A collection bearing uredinia on Astragalus sulphurescens Rydb., sent by Mr. E. Bethel, from Boulder, Colo., was sown Sept. 30, on $A$. carolinianus, and on October 22, uredinia were observed, although they may have appeared somewhat earlier.

We have yet made no appreciable headway toward ascertaining the aecial condition of this rust, but the present cultures do show that the Oxytropis rust, which has usually been kept distinct, is

${ }^{98}$ Mycologia 2: 220. I9ro. 


\section{3}

identical with the widespread Astragalus rust. The species is one that does not readily produce teliospores.

24. Uromyces Medicaginis Pass., on Medicago sativa L., was sent by Mr. H. S. Coe, from Ames, Iowa. Urediniospores were sown September 26, on Medicago sativa in the greenhouse, and uredinia began to appear October 8. On November I4, uredinia from this culture were sown on Medicago satiza, Trifolium pratense, $T$. medium, and $T$. repens, giving uredinia on the first December 3 , but with no infection of the Trifolium plants.

The aecia of Medicago rusts are not definitely known. In Europe a form usually assumed to be the same occurs on Trifolium pratense, and this was made by Schröter to infect Euphorbia Cyparissias. This form has not been detected in America. The present culture seems to show that the Medicago rust will not pass over to Trifolium, at least by means of urediniospores.

25. Gymnosporangium Juniperi-virginianae Schw., on Juniperus virginiana L., collected by Dr. F. D. Kern in the vicinity of Lafayette, Ind., was sown April 7, on Malus Malus, giving numerous pycnia April 19, but the leaves matured before aecia were formed. ${ }^{39}$

26. Gymnosporangium clavipes C. \& P., on Juniperus sibirica Burgsd., was sent by Dr. J. J. Davis, from Wind Lake, Wis., and sown May 3, on Amelanchier erecta and Crataegus tomentosa. giving numerous pycnia on both hosts May 16 , and equally numerous aecia June 6, for the first host and June II, for the second.

Aecia from this culture on Amelanchier erecta were used to sow June 7 , on a small plant of Juniperus sibirica, and many finely developed telia appeared in May I9I I, the exact date not recorded. ${ }^{40}$

These cultures are interesting in showing that the telia mature in the spring following infection, and do not require an additional year as some other species of Gymnosporangium do.

27. Gymnosporangium clavariaeforme (Jacq.) DC., on Juni-

${ }^{29}$ For previous cultures see Jour. Myc. 12: 13. 1906; 13:200. 1907; 14: 17. I908; and Mycol. I: 238. 1909.

${ }^{40}$ For previous cultures see Jour. Myc. 14: 18. 1908; Mycol. I: 239. I909; and 2 : 229. 1910. 


\section{4

perus sibirica Burgsd., was sent by Mr. E. Bethel, from Boulder, Colo., and sown April 7, on the young fruit of Pyrus communis, which fell off before time for infection to show, and also on the leaves of Amelanchier erecta and Crataegus punctata. On the Crataegus a few pycnia showed April 15, but no aecia developed. On the Amelanchier numerous pycnia appeared April I3, and many aecia April $25 .{ }^{41}$

28. Gym nosporangium Nidus-Avis Thaxt, on Juniperus virginiana L., was sent from Washington, D. C., by Dr. Haven Metcalf, and sown April ז6, on leaves of Cydonia vulgaris, giving a few pycnia May 2, and also on the young fruit of Amelanchier vulgaris, giving a few pycnia first noticed May 24. In both instances no further development occurred. ${ }^{42}$

29. Gymnosporangicim cornutum (Pers.) Arth., on Juniperus sibirica Burgsd., sent from Palmer Lake, Colo., by Mr. E. Bethel, was sown May I8 on Sorbus americana, Aronia arbutifolia, and Amelanchier erecta. Infection was secured only on the Sorbus, the pycnia being produced in abundance but tardily, and the date was not taken. The plant did not thrive, and no aecia matured, although on August I6 they were showing. ${ }^{43}$

3o. Gymnosporangium Davisir Kern, on Juniperus sibirica Burgsd., sent by Dr. J. J. Davis from Wind Lake, Wis., was sown May 3, on Aronia arbutifolia, A. nigra, Sorbus americana, Amelanchier crecta and Crataegus tomentosa, without results. Another sowing was made May 12, on the two species of Aronia, which resulted in a few pycnia on A. nigra, showing May 27. Still another sowing on $A$. arbutifolia was made May 18 , and gave a few pycnia May 25. In neither instance did aecia develop. ${ }^{44}$ It is probable that the conditions under which the cultures are made in the greenhouse are not favorable for this rust.

3r. Gymnosporangium Betheli Kern, on Jumiperus scopulorum Sarg., sent by Mr. E. Bethel from Boulder, Colo., was sown

41 For previous cultures see Jour. Myc. 14: I8. 1908; and Mycol. I: 239. 1909.

${ }^{42}$ For previous cultures see Jour. Myc. 14: 19. 1908; and Mycol. 2: 230. 1910.

${ }^{42}$ For previous cultures see Mycol, I: 240. 1909; and 2: 230. 1910.

4 For previous cultures see Mycol. 1: 241. 1909, where an error was made in assuming that this species occurs in Europe; see also Mycol. 2: 216.1910. 
April I6, on Crataegus cerronis A. Nels., giving rise to numerous pycnia April 25, and equally numerous aecia May 23. ${ }^{45}$

32. Gymnosporangium Nelsoni Arth., on Juniperus virginiana L., sent by Professor R. A. Harper from Merrimack, Wis., was sown May 2, on Amelanchier erecta, Cydonia vulgaris and Malus coronaria. Infection was only on Amelanchier, showing an abundance of pycnia May II, and equally numerous aecia June $8 .{ }^{48}$ This rust is not often seen east of the Rocky Mountains. The witches' brooms which are produced have a general resemblance to those of G. nidus-avis, and it may sometimes be confused with that species.

33. Cronartium Quercus (Brond.) Schröt. Aecia (Peridermium Cerebrum Peck) on Pinus virginiana Mill., were sent by Mr. W. H. Long, from the vicinity of Washington, D. C., and sown April 28, on Quercus rubra. The first appearance of uredinia was not recorded, but on May 20, a few uredinia and many telia were observed. ${ }^{47}$

34. Melampsoropsis abietina (A. \& S.) Arth., on Ledum groenlandicum Oeder, sent by Professor W. P. Fraser from Pictou, Nova Scotia, was sown June 15 on Picea Mariana (Mill.) B. S. P., giving numerous pycnia June 23, and aecia about August I2. This connection was first suggested by the field observations of Anton de Bary in the Alps, and by him proven by means of cultures in $1879 .{ }^{48}$ A number of field observations by other mycologists were recorded, tending to fontify the result, but no other cultures were made until I90I, when Klebahn ${ }^{49}$ verified the work of de Bary.

The probable connection of Ledum and Picea rusts in America was discussed by Professor W. G. Farlow in $1885,{ }^{50}$ based largely

${ }^{45}$ For previous cultures see Jour. Myc. 14: 23. 1908; Mycol. I: 240. 1909; and 2: 230 . 1910.

49 For previous cultures see Jour. Myc. 13: 203. 1907; 14: 18. 1908; and Mycol. I : 239. 1909. Studies published by Dr. F. D. Kern (Bull. N. Y. Bot. Gard. 7: 448. Oct. I9II) since this article went to press show that the form used in this culture, and also in the previous ones here referred to, has been erroneously referred to $G$. Nelsoni, it should be called G. juvenescens Kern.

"For previous cultures see Jour. Myc. 13: 194. 1907.

48 Bot. Zeit. $37: 802$. 1879 .

${ }^{49}$ Zeitschr. Pflanzenkr. 12: 17. 1902.

${ }^{50}$ Proc. Amer. Acad. Sci. 20: 320. 1885. 
upon his observations in the White Mountains of New Hampshire, but at that time too little study had been given to the morphological characters of the species inhabiting these two host genera to permit of accurate determination of the various collections, and the conclusions were consequently misleading.

The studies of Dr. F. D. Kern and the writer ${ }^{51}$ a few years since showed that the American aecia previously referred to this species really belonged elsewhere, and that no genuine aecia of the species had been collected in America in all probability. After completing the cultures here recorded some of the resulting material was sent to Professor Fraser, and with a knowledge of the appearance and habit of the aecia thus acquired he was able to go into the field and gather excellent specimens. ${ }^{52}$ The reason they have not been taken before by American collectors is doubtless due to their somewhat inconspicuous and evanescant character.

Successful CUltures REPORTED NOW FOR THE FIRST TIME:The following species have never before been cultivated, in America or elsewhere, so far às the writer knows.

I. Puccinia Crandalli Pam. \& Hume on Festuca confinis Vasey collected by Mr. E. Bethel, at Boulder, Colo., on March I9, 1910, was sown April 21, on Symphoricarpos racemosus, Grindelia squarrosa, Hydrophyllum capitatum and Arnica sp., with infection only on the first. The pycnia began to appear May 9, and aecia May 26, neither in abundance. This was an unsuspected result, and immediately upon detecting evidence of infection, a second sowing was made upon another plant of Symphoricarpos racemosus (May Io), which yielded more pronounced results. Pycnia began to appear in ten days (May 20), and aecia in eleven days more (May 3I), both well formed and numerous.

A second lot of this rust, on Festuca confinis Vasey, was received from Professor A. O. Garrett, collected in City Creek Canyon, Salt Lake City, Utah, April Io, I9Io, and sown on the same date as the previous sowing, May Io. Pycnia began to show May 20, and aecia June 6.

${ }^{51}$ Bull. Torrey Club 33: 429, 430. 1906.

"Cf. Mycologia 3: 69. 19x 
The results of these cultures agree perfectly with Aecidium abundans Peck which was first collected in Colorado, on Symphoricarpos oreophilus, the exact locality not being stated.

2. Puccinia quadriporula Arth., on Carex Goodenovii J. Gay, collected by the writer in the type locality at Isle au Haut, Me., was sown April 18 on Iris versicolor, Boehmeria cylindrica, and Rudbeckia laciniata, with no infection. Again April 26 it was sown on Myrica cerifera, Lysimachia terrestris, Macrocaly.x Nyctelea, Polemonium reptans, Apocynum cannabinum, Senecio lugens, and Aster paniculatus, with infection only on the last, pycnia being first noticed May I3, and aecia appearing May I7, neither very abundant.

Field observations seemed to connect this rust with aecia on Iris, but previous attempts at cultures had given no certain evidence. $^{58}$ The results this year appear beyond question. No other Carex rust grew in the vicinity of the spot where the collection was made. The material used shows only the characteristic rust. The aecia obtained, however, are both in gross and minute characters indistinguishable from those of $P$. Caricis-Asteris Arth. These facts make the status of the species enigmatical. The marked diagnostic characters of $P$. quadriporula and $P$. CaricisAsteris lie in the urediniospore. The former has a somewhat larger urediniospore, more usually globose, and with four, often three, equatorial pores, while the latter has a smaller urediniospore, more ellipsoid or elongated, and with two superequatorial pores. The pore characters are markedly dissimilar, and without intergradations.

Another collection with the spore characters of $P$. quadriporula, made by Professor W. P. Fraser, at Pictou, Nova Scotia, on Carex brunnescens (Pers.) Poir., was sown April II, and again May 6, on Iris versicolor, Urtica gracilis, and Ribes flori$d u m$, with no infection.

3. Puccinia Lithospermi E. \& K., on Evolvulus pilosus Nutt., collected at Amarillo, Texas, by W. H. Long, was sown April 15, on the same species of host, and produced a scanty infection. Pycnia were not observed until May 2; aecia began to appear

${ }^{58}$ See Mycol. I: 230. I909. 


\section{Arthur: Cultures of Uredineae in 1910 198}

May 6. The result shows that the species is eugyrinious and autoecious.

4. Uromyces acuminatus Arth., on Spartina Michauxiana A. S. Hitch. (usually listed as $S$. cynosuroides), collected by Dr. J. F. Brenckle at Kulm, N. D., was sown April 28 on Steironema ciliatum and Polemonium reptans, with abundant infection on the latter only, showing pycnia May 9, and aecia May I4.

A similar collection made by $\mathrm{Mr}$. E. Bethel in the foothills of Colorado was sown May 12, on Steironema ciliatum, Hydrophyllum capitatum, Phlox divaricata, and Polemonium reptans, with very abundant infection only on the last, showing pycnia May 20, and aecia May 26. Another collection made at Fair Oaks, Ind., by Messrs. F. D. Kern and T. Billings, was sown one week later on the same hosts, but gave no infection, doubtless due to the lateness of the season.

These results bear out the field observations of Professor Guy West Wilson, as stated in the report for $1909 .{ }^{54}$ The aecial stage is known in literature as Aecidium Polemonii Peck, and occurs on species of Phlox as well as on Polemonium.

5. Coleosporium Vernoniae B. \& C. Freshly gathered leaves of Pinus taeda L., bearing Peridermium carneum Bosc, gathered by Mr. O. F. Burger at Gainesville, Fla., May 18, I910, were suspended on May 2I, over potted plants of Veronia crinita, Elephantopus carolinianus and Lacinaria scariosa. Contrary to expectation uredinia began to show in abundance June 6 on the Veronia only. Numerous telia began to mature by August I6.

6. Melampsora albertensis Arth., on Populus tremuloides Michx., was sent by Mr. E. Bethel on three different dates, collected at different places in the foothills of Colorado, and all showing telia in resting condition. The first collection was sown April 20, on Larix laricina and Pseudotsuga mucronata, giving infection on the latter only, showing an abundance of pycnia May 2, and an equal abundance of aecia May 9. The second collection (from Plainview, Colo.), was also sown April 20, on the same two hosts, but without results. Later on, May I8, duplicate sowings were made. This time the Larix remained free, and the Pseudotsuga after a long interval was found to have been infected,

"See Mycol. 2: 222. 1910. 
the pycnia and aecia being first noticed June 6 . The third collection was sown May I9, on the same hosts, with infection only on Pseudotsuga, numerous pycnia showing May 3 I, and equally numerous aecia June 9.

The aecia on Pseudotsuga were first brought to my attention by Professor E. W. D. Holway, who sent a collection from Beaver River valley, B. C., in I907. This collection was described by the writer, and named Caeoma occidentale. ${ }^{55}$ The following year Mr. E. Bethel sent collections from Eldorado Springs, Colo., and in 1909 he sent other collections from Eldorado Springs, and also from Tolland and Golden. From observations made at these places Mr. Bethel suggested that the connection between the Caeoma on Pseudotsuga and the Melampsora on Populus was unquestionable. The aecial stage is doubtless rather common throughout the range, but it is so inconspicuous and evanescent that it has been very little collected.

\section{SumMary}

The following is a complete list of the successful cultures made during the year I910. It is divided into two series, species that have previously been grown in cultures and reported by the writer or other investigators, and species whose culture is now reported for the first time.

\section{A: Species Previously Repgrted}

I. Puccinia Grosutitue (Sehtm.) Lagerh. Teliospores from Carex tenuis Rudge and from C. pallescens L., sown on Ribes Cynosbati L.

2. Puccinia Peckii (DeT.) Kellerm.-Teliospores from Carex lanuginosa Michx., sown on Onagra biennis (L.) Scop., and from C. trichocarpa Muhl., sown on O. biennis (L.) Scop. and Meriolix serrulata (Nutt.) Walp.

3. Puccinia Caricis-Solidaginis Arth.-Teliospores from Carex scoparia Schk., sown on Euthamia graminifolia (L.) Nutt.

4. Puccinia Caricis-Asteris Arth.-Teliospores from Carex festiva Dewey, sown on Aster adscendens Lindl.

${ }^{68}$ Bull. Torrey Club 34: 59r. 1907. 
5. Puccinia Opizii Bubák.-Teliospores from Carex siccata Dewey, sown on Lactuca canadensis L. and L. sativa L.

6. Puccinia universalis Arth.-Teliospores from Carex stenophylla Wahl., sown on Artemisia dracunculoides Pursh.

7. Puccinia Caricis (Schum.) Schröt.-Teliospores from Carex aristata $\mathrm{R}$. Br. and $C$. stricta Lam., sown on Urtica gracilis Ait.

8. Puccinia angustata Peck.-Teliospores from Scirpus atrovirens Muhl., sown on Lycopus americanus Muhl.

9. Puccinia Andropogonis Schw.-Teliospores from Andropogon virginicus L., sown on Pentstemon hirsutus (L.) Willd. and from A. scoparius Michx., sown on Pentstemon alpinus Torr.

I0. Puccinia pustulata (Curt.) Arth.-Teliospores from Andropogon furcatus Muhl., sown on Comandra umbellata (L.) Nutt.

II. Puccinia amphigena Diet.-Teliospores from Calamovilfa longifolia (Hook.) Hack., sown on Smilax hispida Muhl.

12. Puccinia Muhlenbergiae Arth. \& Holw.-Teliospores from Muhlenbergia racemosa (Michx.) B. S. P., sown on Callirrhoe involucrata (T. \& G.) A. Gray.

13. Puccinia Rhamni (Pers.) Wettst.-Teliospores from Calamagrostis canadensis (Michx.) Beauv., sown on Rhamnus alnifolia L'Her.

14. Puccinia poculiformis (Jacq.) Wettst.-Teliospores from Agropyron tenerum Vasey, Sitanion longifoliun̨ J. G. Sm., and Agrostis alba L., sown on Berberis vulgaris L.

15. Puccinia subnitens Diet.-Teliospores from Distichlis spicata (L.) Greene, sown on Chenopodium album L.

I6. Puccinia Jamesiana (Peck) Arth.-Teliospores from Atheropogon curtipendulus (Michx.) Fourn., sown on Asclepias syriaca $\mathrm{L}$.

17. Puccinia Seymouriana Arth.-Teliospores from Spartina Michauxiana A. S. Hitchc., sown on Cephalanthus occidentalis L.

18. Puccinia Stipae Arth.-Teliospores from Stipa spartea Trin., sown on Aster ericoides L., A. Novae-Angliae L., A. multiflorus Ait., and Solidago canadensis L., from Stipa sp., sown on Aster Novae-Angliae L., and Grindelia squarrosa (Pursh) Dunal, and from Koeleria cristata (L.) Pers., sown on Senecio lugens A. Gray. 
19. Puccinia argentata (Schultz) Wint.-Aeciospores from Adoxa Moschatellina L., sown on Impatiens aurea Muhl.

20. Puccinia Absinthii DC.-Teliospores from Artemisia sp., sown on $A$. dracunculoides Pursh.

21. Uromyces perigynius Halst.-Teliospores from Carex intumescens Rudge, sown on Aster paniculatus Lam., and from C. deflexa Hornem., sown on Solidago rugosa Mill., and Aster ericoides $\mathrm{L}$.

22. Uromyces Junci (Desm.) Tul.-Teliospores from Juncus Balticus Willd., sown on Carduus Flodmanii Rydb.

23. Uromyces Astragali Sacc-Urediniospores from Aragallus Lamberti (Pursh) Greene, and from Astragalus sulphurescens Rydb., sown on Astragalus carolinianus L.

24. Uromyces Medicaginis Pass.-Urediniospores from Medicago sativa L., sown on same host.

25. Gymnosporangium Juniperi-virginianae Schw.-Teliospores from Juniperus virginiana L., sown on Malus Malus (L.) Britt. 26. Gymnosporangium clavipes C. \& P.-Teliospores from Juniperus sibirica Burgsd., sown on Amelanchier erecta Blanch., and Crataegus tomentosa L., and aeciospores from Amelanchier erecta Blanch., sown on Juniperus sibirica Burgsd.

27. Gymnosporangium clavariaeforme (Jacq.) DC.-Teliospores from Juniperus sibirica Burgsd., sown on Amelanchier erecta Blanch., and Crataegus punctata Jacq.

28. Gymnosporangium nidus-avis Thaxt.-Teliospores from Juniperus virginiana L., sown on Cydonia vulgaris Pers., and Amelanchier vulgaris Moench.

29. Gymnosporangium cornutum (Pers.) Arth.-Teliospores from Juniperus sibirica Burgsd., sown on Sorbus americana Marsh.

30. Gymnosporangium Davisii Kern.-Teliospores from Juniperus sibirica Burgsd., sown on Aronia arbutifolia (L.) Medic., and A. nigra (Willd.) Britt.

3r. Gymnosporangium Betheli Kern.-Telinspores from Juniperus scopulorum Sarg., sown on Crataegus cerronis A. Nels.

32. Gymnosporangium Nelsoni Arth.-Teliospores from Juniperus virginiana L., sown on Amelanchier erecta Blanch. 


\section{Arthur: Cultures of Uredineae in igio

33. Cronartium Quercus (Brond.) Schröt.-Aeciospores from Pinus virginiana Mill., sown on Quercus rubra L.

34. Mclampsoropsis abietina. (A. \& S.) Arth.-Teliospores from Ledum groenlandicum Oeder, sown on Picea Mariana (Mill.) B. S. P.

B. Species Reported Nore for the First Time

I. Puccinia Crandallii Pam. \& Hume.-Teliospores from Fes. tuca confinis Vasey, sown on Symphoricarpos racemosus Michx

2. Puccinia quadriporula Arth.-Teliospores from Cares Goodenovii J. Gay, sown on Aster paniculatus Lam.

3. Puccinia Lithospermi E. \& K.-Teliospores from Evolvulus pilosus Nutt., sown on same species of host.

4. Uromyces acuminatus Arth.-Teliospores from Spartina Michauxiana A. S. Hitch., sown on Polemonium reptans L.

5. Coleosporium Vernoniae B. \& C.-Aeciospores from Pinus taeda L., sown on Vernonia crinita Raf.

6. Melampsora albertensis Arth.-Teliospores from Populus tremuloides Michx., sown on Pseudotsuga mucronata (Raf.) Sudw.

Purdue University

LAFAYETTE, INDIANA. 



\section{3}

\section{CULTURES OF UREDINEAE IN $1911^{1}$}

\section{J. C. Arthur}

The present article is the twelfth of a series of reports ${ }^{2}$ by the writer upon the culture of plant rusts, extending through thirteen consecutive years. The preceding report for the year I9IO, published in Mycologia for January, igi2, contained an unfortunate slip of the pen in the heading of a paragraph at the middle of page 13, where "Grossulariae (Schum.) Lagerh." should read albiperidia Arth. With this change, the discussion which follows reads correctly. The same error occurs on page 30 , twelfth line from the bottom.

The very large majority of the sowings for each year are made during the months of April and May. Hot weather is inimical to the work, except for a few species. Throughout the year IgII unusual high temperature prevailed; after the first week in May the thermometer ranged above $80^{\circ} \mathrm{F}$. during the middle of the day for the remainder of the cultural season. Owing to an unfortunate delay in securing an assistant to prosecute the work, the first sowings were not made until April 19, and the work was scarcely well under way before the hot days began, making it nearly impossible to obtain germination of the spores, or in case of germination to obtain infection of the hosts.

The work of the season was conducted by Mr. Earl A. Trager, a junior high school student of South Bend, Ind., who was recommended by Miss Clara Cunningham, teacher of the natural sciences in the South Bend High School. Mr. Trager conducted the work admirably. He furthermore showed capacity for mastering the technique and for handling the problems involved which compared favorably with that of his more mature and

${ }^{1}$ Presented before the Botanical Society of America at the Washington meeting, December 27, 1911.

${ }^{3}$ See Bot. Gaz. 29: 268-276; 35 : 10-23; Jour. Myc. 8: $51-56 ; 10: 8-21$; II : $50-67 ; 12: 11-27 ; 13: 189-205 ; 14: 7-26 ;$ Mycol. I: 225-256; $2: 213-240$; and $4: 7-33$. 1912. 
experienced predecessors. The paucity of results is wholly ascribable to the lateness in beginning the work and to the unseasonable weather.

Only one direct excursion was made to supply material for this year's cultures. Early in March the writer, accompanied by Mr. Ray Stretch, a graduate of the Lafayette High School, who rendered efficient service and proved a keen observer, visited the region bodering the Mississippi Sound from Ocean Springs to Pass Christian, Miss., well known from the thorough field work and numerous publications of Professor S. M. Tracy, whose home is at Biloxi, between the two places mentioned. The special object in view was to secure material of Gymnosporangium bermudianum, the only autoecious species known belonging to this genus, both for culture and for morphological work. Hope was also entertained that fresh material of species of Peridermium, with field observations to assist in culture work, might be secured. The region was found to possess the fewest rusts, both in number of species and in their abundance, of any section yet visited for observational purposes.

Upon request a visit to Newfield, N. J., was made by Dr. Frank D. Kern, studying during the collegiate year at Columbia University, New York, accompanied by Mr. B. O. Dodge, a graduate student of the same institution. The object was to secure material of several species of Gymnosporangium for cultures. Newfield was chosen, as it was for many years the home of Mr. J. B. Ellis, and his collections show a number of hitherto poorly understood species, whose aecia are still unknown. Probably the most interesting of these is a small foliicolous form on the white cedar, recently described as G. fraternum Kern. A note found in the Ellis collection at the New York Botanical Garden gave evidence that it was common in a certain swamp twenty-five years ago. The particular spot was found, and the fungus secured. One day was spent in this vicinity, and seven species of Gymnosporangium were collected. Among these were G. Ellisii, whose aecial stage is suspected to be the rare Roestelia hyalina, and the recently named G. effusum. The last is a large form on branches, very destructive to the red cedar, and yet never issued in exsiccati. It is the only one collected on this trip from which infection was obtained. 


\section{Arthur: Cultures of Uredineae in I9IT 2055}

An extended excursion, but too late for the season's cultures, was made by the writer and Dr. Frank D. Kern during August and September to the foothills of Colorado, between Boulder and Pueblo, and to some extent in the adjacent mountains. This is the richest rust flora, both in species and frequency of occurrence, yet encountered. The dryness of the atmosphere, which promotes the growth of the rust on the individual hosts, while checking the spread from plant to plant, makes the region an exceptionally fine one for field study of relationships between the alternate stages of heteroecious species. Our work was enormously promoted by assistance from Mr. E. Bethel, of Denver, whose exact, enthusiastic, and prolonged observations over the whole region visited cannot be too highly commended. The freedom with which he turned over for our use his most important discoveries and conclusions must unfortunately be inadequately repaid. It was due to his assistance that this excursion proved the richest in results by far of any yet undertaken, results that are only slightly reflected in this report, but have paved the way for important cultures in I9I2.

On the eleventh of November, after a day of summer heat, a hurricane did great injury to the conservatory and greenhouse of the Experiment Station, in which many plants for the next season's experiments were growing. At about nine o'clock in the evening a large part of the glass in these houses, and in the offices and laboratories of the department of botany, was broken in by the violence of the wind. The heavy rain which was falling soon turned to snow, and the temperature dropped to many degrees below freezing. When the damage was detected at about eight o'clock the next morning, the plants were largely beyond recovery.

- Hearty thanks are due to the following persons who contributed material for study: Mr. E. Bethel, Denver, Colo., heading the list with 87 collections; Messrs. E. W. Olive, Brookings, S. D., J. M. Bates, Red Cloud, Neb., J. Dearness, London, Ont., and W. P. Fraser, Pictou, Nova Scotia, each sent between Io and 30 collections, while much smaller numbers were sent by Messrs. E. Bartholomew, Stockton, Kans., C. F. Baker, Claremont, Calif., J. F. Brenckle, Kulm, N. D., J. C. Blumer, Tucson, 
Ariz., H. S. Coe, Ames, Iowa, H. M. Jennison, Crawfordsville, Ind., S. Kusano, Tokio, Japan, E. F. Smith, Hannaford, N. D., E. M. Wilcox, Lincoln, Neb., J. J. Wolf, Durham, N. C., and F. Vasku, Oberlin, Ohio. Seeds and living plants were also sent by a number of botanists to provide host plants of native species required in the work. To all these and to others who aided in the work of the year grateful acknowledgment is due and is hereby extended. The investigations were carried out under the auspices of the Indiana Experiment Station, and financed from the Adams fund.

During the present season I93 collections of material with resting spores and 37 collections with active spores were employed, from which 69I drop cultures were made to test the germinating condition of the spores. Out of the 193 collections with resting spores 156 failed to germinate, leaving 37 collections available for experimental tests. Altogether about 235 sowings were made and 32 infections obtained. All but three sowings were made on plants growing in pots in the greenhouse. The most important conclusions derived from a study of the results are given.in the following paragraphs.

Negative Results. - It has been customary in these reports to record sowings with germinating spores when no infections were obtained, to serve as a guide in selecting hosts for future attempts. This year only a few instances will be given, as all sowings made after the heated term began, May 8 , are deemed too uncertain to be of value.

I. Puccinia tosta Arth., on Sporobolus asperifolius (Nees \& Meyen) Thurb., collected at Denver Colo., by Mr. E. Bethel, was sown April 19, on Atriplex confertifolia and Malvastrum coccineum, with no infection. The day following a collection with same data from Delta, Colo., was sown on Aesculus glabra and Xanthoxylum americanum, and again, May Io, on ten other hosts, with no infection.

The resemblance of this rust and of its host to that of Puccinia subnitens Diet., on Distichlis spicata, is very marked, as seen in the field. The two species grow under the same conditions, often intermixed, and might be expected to have the same aecial 


\section{Artuur: Cultures of Uredineae in igi 207}

hosts, a possibility barely touched by the present attempt at culture.

2. Puccinia Schedonnardi K. \& S., on Schedonnardus paniculatus (Nutt.) Trel., collected at Stockton, Kans., by Mr. E. Bartholomew, was sown April 19, on Aesculus glabra, Xanthoxylum americanum, Hydrophyllum capitatum, Sidalcea oregana, Callirrhoe involucrata, and Onagra pallida, with no infection. Similar material in former years was sown on twenty-eight other species of hosts. ${ }^{3}$

3. Gymnocunia interstitialis (Schl.) Lagerh. No attempts have been made, so far as the writer knows, to propagate any species of rust by means of its pycniospores, except one made by Dr. Frank D. Kern in 1910, and not heretofore reported. $\mathrm{He}$ sowed pycniospores from Amelanchier erecta, belonging to Gymnosporangium clavariaeforme, upon young leaves of $A$. erecta by pricking and otherwise mutilating the epidermis, but without results. It is well known that the growth of such spores soon ceases in a liquid culture the same as with any other rust spores, only sooner, as they are much smaller and contain less nutriment. But it has not been shown that they will not form a mycelium when suitably placed upon or within the tissues of a host plant. The prominent and abundant pycnia of the blackberry rust, which mature in advance of the aecia, seem especially favorable for such a trial. Pycniospores from Rubus allegheniensis taken when perfectly fresh were sown May 9 on young leaves of two different plants of the same species, which were well established in pots. The spores were not only placed on the surface of the partly grown leaves, but were also pricked into the tissues in places with a needle. This was done to imitate the probable dispersion of such spores by insects, for which the nectar secreted by the sori may have an attraction. No infection was obtained. Neither in this attempted culture nor in that by Dr. Kern was any examination made to ascertain what growth the pycniospores may have made.

Successful cultures SUPPLEMENTING PREvious WORK.-The facts derived by growing the following species of rusts supple-

${ }^{3}$ See Bot. Gaz. 35: I1. 1903; Jour. Myc. 13: 193. 1907; 14: 11. 1908; Mycol. I : 231. 1909 ; and 4: 10. 1912. 
ment those obtained from previous cultures in this series or from cultures recorded by other American or European investigators.

I. Puccinia Peckir (DeT.) Kellerm., on Carex lanuginosa Michx., collected at Red Cloud, Neb., by Rev. J. M. Bates, was sown May 20 on Onagra biennis and Meriolix serrulata, with no infection on the latter, but with abundant pycnia on the former May 29, and aecia June I.4 Similar cultures on Onagra biennis were made from undetermined species of Care.r collected by Mr. E. Bethel, at Denver, Colo., and by Dr. J. F. Brenckle, at Kulm. N. D.

2. Puccinia angustata Peck, on Scirpus cyperinus (L.) Kunth, collected at London, Ont., by Mr. J. Dearness, was sown May 25 on Lycopus americanus, giving rise to pycnia first seen June 3 , and aecia June $5 .^{5}$

3. Puccinia Phragmitis (Schum.) Körn., on Phragmites communis Trin., collected at Cowles, Neb., by Rev. J. M. Bates, was sown May 9 on Rumex crispus, giving rise to abundant pycnia and aecia first observed May $23{ }^{6}$

4. Puccinia cinerea Arth., on Puccinellia airoides (Nutt.) Wats. \& Coult., collected at Lewis Station, Colo., by Mr. E. Bethel, was sown May ro on Orygraphis Cymbalaria, giving rise to pycnia May 16 , and an abundance of aecia May $20 .^{\top}$

5. Puccinia subnitens Diet., on Distichlis spicata Greene, collected at Lewis Station, Colo., by Mr. E. Bethel, was sown May 2, on Sarcobatus vermiculatus, Monolepis Nuttalliana, Cleome spinosa, Atriplex hastata, and Chenopodium album, with no infection on the first two, but with numerous pycnia on the others, appearing May II, 12 and 16 , respectively, followed by aecia on the Cleome and Atriplex, on both appearing May $15 .{ }^{8}$

For previous cultures see Bot. Gaz. 35: 13. 1903; Jour. Myc. 8: 52 . I902; II : 58. 1905; 12: 15. 1906; 13: 195. 1907; Mycol. I: 233. 1909; 2: 222. 1910; and $4: 15.1912$.

${ }^{5}$ For previous cultures see Bot. Gaz. 29: 273. I900; Jour. Myc. 8: 53. 1902 ; II : 58. 1905; 13: 196. 1907; 14: 14. I908; Mycol. I: 234. I909; and 4: 17. I912.

${ }^{6}$ For previous cultures see Bot. Gaz. 29 : 269. I900; Jour. Myc. 9 : 220. 1903; 14: I 5. 1908; and Mycol. 2: 225. 1910.

Tor a previous similar culture see Mycol, 1: 246. 1909.

${ }^{8}$ For previous oultures see Bot. Gaz. 35: 19. I903; Jour. Myc. II : 54.1905 ; 12: 16. 1906; 13: 197. 1907; 14: 15. 1908: Mycol. I: 234. 1909; 2: 225. 1910; and $4: 18,1912$. 


\section{$\$ 609$}

Arthur: Cultures of Uredineae in I9II

6. Uromyces Peckianus Farl., on Distichlis spicata (L.) Greene, obtained in the field March 29, 1911, at Pictou, Nova Scotia, by Professor W. P. Fraser, was sown April I9 on Tissa canadensis and Lepidium virginicum, with no infection. Another collection with same data but obtained in the field April 13, I9II, was sown on Bursa Bursa-pastoris, Lepidium virginicum, Corydalis montanum, Tissa canadensis, Cleome spinosa, and Atriplex hastata, with no infection except on the last, which showed numerous pycnia May 16, and an abundance of aecia May 22. Still another collection with same data but obtained in the field April 27, I9I I, was sown May 5 on Chenopodium album and on the same six hosts as the last, with infection only on Atriplex, showing pycnia May I7, and aecia May 29, both in abundance.

A former attempt at cultures with this species proved futile, ${ }^{8}$ but Professor Fraser ${ }^{10}$ met with better success in cultures made by himself during the same season of I9Io. He was able to abundantly infect both Atriplex hastata and Chenopodium album from teliospores on Distichlis spicata. Material from his cultures was most generously sent to the writer. Since then he has sent material of his more extensive and important cultures of I9II, which need not be specifically mentioned here, although they strengthen the conclusions about to be stated.

A careful morphological study of herbarium material, both as collected in the field and as grown from cultures, shows no appreciable difference in the gross or microscopical characters between the several stages of Puccinia subnitens Diet. and Uromyces Peckianus Farl., except in one particular-the unilocular or bilocular condition of the teliospore. When the teliospore is twocelled, as in the Puccinia, it is correspondingly longer than, but essentially the same otherwise as the one-celled teliospore, found in the Uromyces. The aecia in their peridial cells and aeciospores, and the uredinia in their appearance and in their urediniospores, when taken by themselves are indistinguishable. The only character with which to separate the so-called two species is the presence or absence of a septum in the teliospore.

Both the Puccinia and the Uromyces show marked racial tendencies in the selection of aecial hosts, seemingly correlated with

- See Mycol. 4: 12. 1912.

${ }^{30}$ Mycol. 3: 72-74. 1911. 


\section{6

geographical position, but more information is needed regarding the races of the Uromyces before a full comparison can be instituted. Whether the aecia of the Uromyces ever occur upon any family other than the Chenopodiaceae, as do those of the Puccinia, yet remains uncertain, but it is confidently expected that such will be the case. In any event there is every reason, except that of nomenclatorial expediency, to consider Puccinia subnitens and Uromyces Peckianus telial races of one and the same species which in turn may be separable into geographical races in accordance with their selection of aecial hosts.

7. Uromyces Medicaginis Pass. The urediniospores from plants of Mcdicago sativa L., carried over the winter in the greenhouse, were sown March 8 on Mcdicago sativa, Trifolium pratense, T. medium, and $T$. repens, producing infection only on the first, uredinia showing March 22. A similar set of sowings was made April 28 on other plants of the same four hosts, with similar result, only the Medicago being infected, showing uredinia May 12. The work of 19 Io is thus confirmed. ${ }^{11}$

8. Gymnosporangium Nidus-avis Thax., on Juniperus urrginiana L., was sent by Dr. Frank D. Kern from Newfield, N. J., and sown May 4 on leaves of Cydonia vulgaris, Malus coronaria, Amelanchier erecta, and also on the fruit of the last. The only infection was on the fruit of the Amelanchier, showing numerous pycnia May I2, and aecia in great abundance May 24. Another collection on the same host sent by Professor E. Mead Wilcox from Lincoln, Neb., was sown May II on leaves of the same three hosts, with infection only on the Malus, giving pycnia June 2 , but the leaves dying before aecia formed. ${ }^{12}$

9. Gymnosporangium Clavariaeforme (Jacq.) DC., on $J u$ niperus sibirica Burgsd., was sent by Mr. E. Bethel from Lake Eldora, Colo., and sown May 25 in the open orchard on fruits of pears and apples, and in the greenhouse on leaves of $C y d o n i a$ vulgaris and fruits of Amelanchier erecta, with no results except on fruits of Amelanchier, giving abundant pycnia May 3I, and very abundant aecia June $15 .{ }^{13}$

${ }^{11}$ See Mycol. 4: 24. I9I2.

12 For previous cultures see Jour. Myc. $2: 230$. 1910 ; and 4:25. 1912.

${ }^{13}$ For previous cultures see Jour. Myc. 14: 18. 1908; Mycol. I : 239. 1909; and $4: 24.1912$. 


\section{Arthur: Cultures of Uredineae in igil 457}

10. Gymnosporangium inconspicuum Kern, on Juniperus utahensis (Engelm.) Lemmon, sent by Mr. E. Bethel from Paonia, Colo., was sown April 7 on leaves of Amelanchier crecta and of $A$. zulgaris, with infection only on the latter, showing pycnia April 24, but not maturing aecia. ${ }^{14}$

II. Gymnosporangium Libocedri (P. Henn.) Kern, on Libocedrus decurrens Torr., sent by an unknown correspondent, was sown April I7 on Amelanchier vulgaris, Crataegus tomentosa, C. cerronis, and Sorbus aucuparia, with no infection on the last, but pycnia showing on the other hosts April 25, 26 and 28 respectively, and abundant aecia on the Amelanchier, showing May $16 .{ }^{15}$

12. Gymnosporangium Juniperinum (L.) Mart., on Jumiperus sibirica Burgsd., sent by Mr. E. Bethel from Palmer Lake, Colo, was sown April 26 on Sorbus aucuparia, without producing infection. It was again sown May 5 on $S$. americana, and produced pycnia May 20 in abundance, but did not develop aecia.

The species has not been cultivated before from American material. The first cultures were made in Europe by Robert Hartig $^{16}$ about 1882 at Munich, and the species named G. tremelloides, from its conspicuous telia. The Linnaean name appears to have been transferred by Oersted in 1866 to a much less conspicuous form, as pointed out by Kern, ${ }^{1 i}$ but it seems best now to follow the original usage. The galls used in the present culture were on small branches and about one centimeter across.

i3. Coleosporium Vernoniae B. \& C. A collection of Peridermium carneum Bosc, on Pinus taeda L., collected by Mr. Ray Stretch and the writer at Mississippi City, Miss., was sown March 6 on Laciniaria scariosa and Vernonia gigantea, with infection only on the latter, uredinia showing March 22. Three other collections on Pinus taeda L., made by the same persons at Biloxi, Miss., were each sown March 8 on Laciniaria scariosa and L. punctata, with no infection. The results confirm the work of $1910 .^{18}$

"For previous cultures on fruit of Amelanchier see Jour. Myc. 14: 24. I 908.

${ }^{18}$ For previous cultures see Mycol. I: 252. 1909.

${ }^{18}$ Hartig. Lehrb. Baum-Kr. 133. 1882.

it Science 27: 930, 1908: Bull. Torrey Cltb 35: 499. 1908; and Bull. N. Y. Bot. Gard. 7 : 458, г 9 ז 1 .

${ }^{18}$ See Mycol. 4: $29 . \quad 1912$. 
I4. Melampsora albertensis Arth., on Populus tremuloides Michx., from Palmer Lake, Colo., sent by Mr. E. Bethel, was sown April 20 on Larix laricina, Ribes Cynosbati and Pseudotsuga mucronata, with infection only on the last, showing pycnia in abundance May 4, and aecia May 9. ${ }^{19}$ On our excursion to Colorado in September Dr. Kern and the writer in company with Mr. Bethel observed great areas of the mountain sides covered with the yellowed foliage of $P$. tremuloides, almost every leaf of which showed uredinia and telia of this rust. It seems remarkable there should be so few collections of it in herbaria, and also of its aecia on Pseudotsuga.

15. Melampsorella elatina (A. \& S.) Arth. Part of a large witches' broom of Aecidium elatinum A. \& S., on Abies lasiocarpa Nutt., was sent by Mr. E. Bethel from Lake Eldora, Colo., 9,000 feet altitude, and sown August 8 on Cerastium oreophilum, giving an exceedingly abundant infection of uredinia, first recorded on September 7. This is the first culture of the species with American material. In Europe cultures with aeciospores have been made by von Tubeuf, ${ }^{20}$ Klebahn, ${ }^{21}$ and Ed. Fischer, ${ }^{22}$ and indications of races have been found. This is an interesting species of rust from the unusual fact of both phases having perennial mycelium.

Successful CUltures REPORTED NOW FOR THE FIRST TIME.The following species have never before been cultivated, in America or elsewhere, so far as the writer knows. It is much to be regretted that some of the species could not be brought to full development, but although the results are in part imperfect, they represent most important additions to previous knowledge.

I. Puccinia Lygodesmiae Ellis \& Ev., on wintered-over stems of Lygodesmia juncea (Pursh) D. Don, collected April 6, I9I I, by Mr. E. Bartholomew, at Stockton, Kans., was sown on plants

${ }^{19}$ For previous cultures see Mycol. 4:29. I9r2.

${ }^{20}$ Deuts. Bot. Ges. 19: 433. I901 ; Arb. Biol. Abth. Land.-Forstw. Kais. Gesundh. 2 : 368.

${ }^{21}$ Jahr. Wiss. Bot. 35 : 699. I901; Zeits. Pf.-Kr. 12: 139. 1902; and Jahr. Hamb. Wiss. Anst. 20 $: 31$. 1902.

22 Ber. Deut. Bot. Ges. 19: 397. I901 ; Zeits. Pf.-Kr. II : 321. 1901; and 12: 193. 1902. 


\section{3

of the same species April 19, and characteristic telia were observed May 3, without being preceded by pycnia or other sporeforms. The species clearly produces but the one form of spore in its life cycle. The aecia often found on this host are undoubtedly heteroecious.

2. Aecidium monorcum Peck, on Arabis sp. Living plants of some smooth leaved species of Arabis bearing aecia were sent by Mr. E. Bethel from Boulder, Colo., 5,000 feet altitude, and arranged May 9 over plants of Koeleria cristata, Stipa viridula, and Trisetum subspicatum, followed by infection only on the last, uredinia and telia being first observed June I. Similar plants bearing aecia were also sent by Mr. Bethel from Lake Eldora, Colo., 9,000 feet altitude, and placed over plants of Koeleria cristata and Trisetum majus, followed by infection on the latter only, uredinia and telia being first observed July 24 .

The results of the cultures appear unequivocal. The aecia used belong to a form on Arabis, and probably also on related genera, very common throughout the Rocky mountain region, which infests the whole plant and usually prevents it from flowering, consequently the determination of hosts is usually difficult and often impossible. Whether all collections labelled Aecidium monoicum Peck belong here may be left to future ex amination, but most of them doubtless do so, although there may be races going to different species of grasses. A bright yellow form on Cheiranthus Menziesii from Nevada was named Aecidium auriellum by Mr. Peck, and may be identical with the Arabis forms, as the difference in color appears to be incidental.

The telial phase has passed under the name Puccinia Triseti Erikss., a name which belongs to a species with covered telia, that has not with certainty been found in America. The rust with similar naked telia on Koeleria and Stipa. Puccinia Stipae Arth., is almost identical in morphological characters, but it forms the curious Aecidium sclerothecioides E. \& E. on composites. There is, moreover, an adaptive distinction-the Trisetum form is capable of germination as soon as the teliospores are mature, while in $P$. Stipae the teliospores require a period of rest, and first show their viable character the following spring. Teliospores from the first of the above recorded cultures were tested 
in drop culture, and gave abundant and vigorous germination after twelve hours. Sowings were at once made June 29 on two plants of Arabis in the rosette stage, grown from seed sent by Mr. Bethel from Colorado. One plant flowered later and showed no evidence of infection. The other plant gradually developed numerous lateral buds, forming a compact mass of small rosettes. This rather abnormal development seems to indicate a probable infection, but the proof must await the elongation of the stems at flowering time next spring.

The credit for detecting the probable connection of these aecial and telial forms is to be shared by Mr. A. O. Garrett and Mr. E. Bethel. Cn packet 75 of the Fungi Utahensis, Aecidium monoicum on Arabis Drummondii, Mr. Garrett adds the note, "apparently connected with a rust on Trisctum subspicatum." This collection was made July 22, 1905. and in a letter dated April 30, 1906 , he writes: "On July 22 I made a collection of aecidia on Arabis Drummondii. The plants were in an open place on the mountain side between spruce timber on either side. On August 2I I returned to the spot to hunt for the alternate form of the A. monoicum. Upon reaching the locality I found a plant of Trisetum subspicatum, and on it I found teleutospores [distributed in Fungi Utahensis 194]. Immediately next to it I found a dried up plant of $A$. Drummondii with abundant aecidia. Looking further, I found that wherever I found the III, I found I, although in a few cases I found I without running across III." It should be borne in mind that these observations were made in the arid region of the Rocky mountains, where juxtaposition is more significant than in more humid regions. Mr. Bethel made similar observations at various times in Colorado, and is, moreover, convinced from his field studies that the same species of rust occurs on Koeleria and Stipa. This may be true, and collections in the herbarium seem to justify the opinion, at least for Koeleria, but cultures are yet wanting, material for which should be gathered in late sumper or autumn, and not in spring. In a letter dated April 9, I9II, Mr. Bethel makes the significant statement: "The Koeleria and Trisetum rusts have a strange way of disappearing. It is almost impossible to find them in the spring. I brought home plants of both Koeleria and 


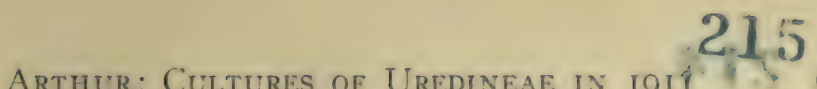

Arthur: Cultures of Uredineae in IgI 1 is

Trisetum last fall which were very badly rusted, and planted in the garden. However, this spring I can see the telia on only one leaf, and that is the Trisetum." Even the rust on the one leaf may have been another species. The evanescent character of this species corresponds to that of Puccinia Eatoniae Arth., having aecia on Ranunculus abortizus from a diffused mycelium and appearing over the whole surface of the leaf early in spring.

As the rust is now for the first time clearly recognized, it is herewith distinctively named and characterized.

Puccinia monoica (Peck) n. nom. (Aecidium monoicum Peck, Bot Gaz. 4: 230. I879.)

O. Pycnia amphigenous, thickly scattered over large areas, preceding or among the aecia, honey-yellow becoming brownish, sub-epidermal, flattened-globose, $90-160 \mu$ in diameter by $60-112 \mu$ high; ostiolar filaments $30-90 \mu$ long.

I. Aecia chiefly hypophyllous, evenly and thickly scattered, usually occupying the whole under surfaces of the leaves, cupulate or short cylindrical, $0.3-0.4 \mathrm{~mm}$. in diameter; peridium whitish, the margin erect or spreading, somewhat lacerate, the peridial cells rhomboidal, $29-34 \mu$ long, the outer wall $7-10 \mu$ thick, striate, the inner wall $3-3.5 \mu$ thick, verrucose; aeciospores globoid, $15-23$ by $18-25 \mu$, the wall colorless, $1.5-2.5 \mu$ thick, rather finely verrucose.

II. Uredinia chiefly epiphyllous, somewhat gregarious, oval or oblong, $0.5^{-1} \mathrm{~mm}$. long, cinnamon-brown, pulverulent; urediniospores broadly ellipsoid or obovoid, I0-2I by $24-3$ I $\mu$, the wall cinnamon-brown, about $2 \mu$ thick, finely and closely echinulate, the pores $6-8$, scattered.

III. Telia chiefly epiphyllous, more or less gregarious, oval, oblong, or roundish, $0.5^{-1} \mathrm{~mm}$. long, pulvinate, chocolate-brown or cinereous by germination at maturity, early naked; teliospores ellipsoid or clavate-oblong, $16-24$ by $34-45 \mu$, the wall cinnamonbrown, I-I.5 $\mu$ thick, thicker at apex, 5-10 $\mu$, smooth ; pedicel nearly or quite colorless, rather slender, once to twice length of spore.

$\mathrm{O}$ and I. Pycnia and aecia on various species of Arabis throughout the Rocky mountain region, type collection from Colorado, on Arabis retrofracta. made by T. S. Brandegee.

II and III. Uredinia and telia on various species of Trisetum, the present known geographical range not so great as for the aecial stage.

3. Gymnosporangium Nelsoni Arth. (G. durum Kern), on Juniperus utahensis (Engelm.) Lemmon, sent by Mr. E. Bethel from Delta, Colo., was sown April 5 on Amelanchier vulgaris, 
A. erecta, Crataegus cerronis, Philadelphus coronarius, and on the last species once more April 12. The only infection was on Amelanchier vulgaris, showing pycnia April 24, but failing to mature aecia. Other sowings made in May were without results. The connection with aecia on Amelanchier had been predicted by $\mathrm{Mr}$. Bethel from his field observations in Colorado from 1907 to the present season, and also by Mr. A. O. Garrett in Utah, 19I0. The same kind of observation is recorded by Tracy \& Earle for southern Colorado in $1898{ }^{23}$ The galls used for these sowings were on small twigs, globoid, and from I to 2 $\mathrm{cm}$. in diameter. This form, generally distributed under the name of G. durum Kern, has recently been united by Dr. Kern ${ }^{24}$ with $G$. Nelsoni Arth. On the type specimens of the latter the galls are small, only $\mathrm{I}-8 \mathrm{~mm}$. in diameter, and hence not at first readily identified with the large woody galls, which have been called G. durum.

All cultures heretofore reported in this series under the name G. Nelsoni belong not to this species but to G. juvenesccns Kern, as stated in the report for $1910 .^{25}$ The latter is a species producing witches' brooms, but not woody galls.

4. Gymnosporangium Kernianum Bethel, on Juniperus utahensis (Engelm.) Lemmon, sent by Mr. Bethel from Paonia, Colo., was sown April 7 on Amelanchier vulgaris, and Crataegus cerronis, with infection only on the Amelanchier, showing pycnia April I7, but not maturing aecia. Another sowing on Amelanchier vulgaris April I7 was without result, and the same was true of another collection from Paonia, Colo., sown on the same day. The failure to secure aecia makes it impossible to identify the aecia of this species among the many forms occurring on Amelanchier, although it is doubtless already in the hands of collectors. So far as the evidence goes it bears out Mr. Bethel's surmise ${ }^{26}$ regarding the aecial hosts. This culture is referred to by Kern ${ }^{27}$ in his monograph on the genus Gymmosporangium.

5. Gymnosporangium effusum Kern, on Juniperus virginiana

${ }^{23}$ Greene, Plantae Bakerianae I: I9. $\mathbf{x} 90 \mathrm{r}$.

${ }^{24}$ Bull. N. Y. Bot. Gard. $7: 448,470$. 19 Ir.

${ }^{25}$ Mycol. 4 : 26. I9I2.

${ }^{26}$ See Mycol. 3 : $158 . \quad 19$ I 1 .

${ }^{27}$ See Bull. N. Y. Bot. Garden $7: 449$. r9ri. 


\section{ARTHUR: Cultures of UREDINEAE in IOI 217}

L., collected at Newfield, N. J., by Messrs. F. D. Kern and B. O. Dodge, was sown May 4 on Aronia arbutifolia, Amelanchier canadensis, Pyrus communis, Malus coronaria, and M. Malus, with infection on the first only, showing pycnia in abundance June 15 , but failing to develop aecia.

Although this infection did not proceed to a sufficient development to show the identity of the aecia, yet there are some reasons, chiefly relating to host and gengraphical distribution for thinking that we are dealing with Roestelia transformans Ellis, which was described by Mr. Ellis from material collected at Newfield, N. J., on Aronia arbutifolia.

6. Gymnosporangium gracilens (Peck) Kern \& Bethel ( $G$. speciosum Peck), on Juniperus monosperma (Engelm.) Sarg., sent by Mr. Bethel from Trinidad, Colo., was sown April 26 on Crataegus tomentosa, Sorbus aucuparia, and Philadelphus coronarius, with heavy infection on the last, showing pycnia May 6 , and aecia May 29. Before the infection had become certain another sowing was made May I on Amelanchier vulgaris, and the day following again on another plant of the same host, and also on the fruit of $A$. erecta, as well as the leaves of Philadelphus coronarius. Again infection was secured only on the Philadclphus, the pycnia showing in the greatest abundance May I3, and aecia June 8.

This connection was suggested by Mr. Bethel, who has given a history of his observations in a recent number of Mycologia. ${ }^{28}$ The result of this set of cultures was communicated to Dr. F. D. Kern, then residing in New York, which enabled him to complete the description and synonymy of the species and to list the aecial hosts in his monograph of the genus Gymnosporangium. ${ }^{20}$ The connection is especially notable, as it carries the aecial hosts of Gymnosporangium outside the families of Malaceae and Rosaceae, into the Hydrangiaceae. As the studies of this genus progress more and more evidence is secured to show that it possesses outlying species approaching in form and habit some of those in other genera.

${ }^{28}$ Bethel, Notes on some species of Gymnosporangium in Colorado, Mycol. 3: 156-160. 1911.

${ }^{20}$ See Bull. N. Y. Bot. Garden 7: 458. x 9 11。 
The ease with which infection of the garden Philadelphus, originally a native of the Caucasus, was secured proved a surprise. Every effort was made to obtain native species of the genus, but without success until too late for culture work.

\section{SumMary}

The following is a complete list of the successful cultures made during the year I9II. It is divided into two series, species that have previously been grown in cultures and reported by the writer or other investigators, and species whose culture is now reported for the first time.

\section{A. Species Previously Reported}

I. Puccinia Peckii (DeT.) Kellerm.-Teliospores from Care. lamuginosa Michx., sown on Onagra biennis (L.) Scop.

2. Puccinia angustata Peck.-Teliospores from Scirpus cyperinus (L.) Kunth, sown on Lycopus americanus Muhl.

3. Puccinia Phragmitis (Schum.) Körn.-Teliospores from Phragmites communis Trin., sown on Rumex crispus L.

4. Puccinia cinerea Arth.-Teliospores from Puccinellia airoides (Nutt.) Wats. \& Coult., sown on Orygraphis Cymbalaria (Pursh) Prantl.

5. Puccinia subnitens Diet.-Teliospores from Distichlis spicata (L.) Greene, sown on Cleome spinosa L., Atriplex hastata L., and Chenopodium album L.

6. Uromyces Peckianus Farl--Teliospores from Distichlis spicata (L.) Greene, sown on Atriplex hastata L.

7. Uromyces Medicaginis Pass.-Urediniospores from Medicago sativa L., sown on same species of host.

8. Gymnosporangium Nidus-avis Thax.-Teliospores from Juniperus virginiana L., sown on fruits of Amelanchier erecta Blanch. and leaves of Malus coronaria (L.) Mill.

9. Gymnosporangium clavariaeforme (Jacq.) DC.-Teliospores from Juniperus sibirica Burgsd., sown on fruits of Amelanchier erecta Blanch.

I0. Gymnosporangium inconspicuum Kern.-Teliospores from Juniperus utahensis (Engelm.) Lemmon, sown on leaves of Amelanchier vulgaris Moench. 
II. Gymnosporangium Libocedri (P. Henn.) Kern.-Teliospores from Libocedrus decurrens Torr., sown on Amelanchier vulgaris Moench, Crataegus tomentosa L., and C. cerronis A. Nels.

12. Gymnosporangium juniperinum (L.) Mart. (G. tremelloides R. Hartig).-Teliospores from Juniperus sibirica Burgsd., sown on Sorbus americana Marsh.

13. Coleosporium Vernoniae B. \& C.-Aeciospores from Pinus taeda L., sown on Vernonia gigantea (Walt.) Britton.

I4. Melampsora albertensis Arth.-Teliospores from Populus tremuloides Michx., sown on Pseudotsuga mucronata (Raf.) Sudw.

15. Melampsorella elatina (A. \& S.) Arth.-Aeciospores from Abies lasiocarpa Nutt., sown on Cerastium oreophilum Greene.

B. Species Reported Now for the First Time

I. Puccinia Lygodesmiae Ellis \& Ev.-Teliospores from $L y^{\prime}$ godesmia juncea (Pursh) D. Don, sown on the same species of host.

2. Puccinia monoica (Peck) Arth.-Aeciospores from Arabis sp., sown on Trisetum subspicatum (L.) Beauv., and T. majus (Vasey) Rydb.

3. Gymnosporangium Nelsoni Arth. (G. durum Kern).-Teliospores from Juniperus utahensis (Engelm.) Lemmon, sown on Amelanchier vulgaris Moench.

4. Gymnosporangium Kernianum Bethel.-Teliospores from Juniperus utahensis (Engelm.) Lemmon, sown on Amelanchier vulgaris Moench.

5. Gy'mnosporangium effusum Kern.-Teliospores from Juniperus virginiana L., sown on Aronia arbutifolia (L.) Ell.

6. Gymnosporangium gracilens (Peck) Kern \& Bethel.-Teliospores from Juniperus monospcrma (Engelm.) Sarg., sown on Philadelphus coronarius L.

Purdue University,

LAFAyEtTE, Indiana. 



\section{CULTURES OF UREDINEAE IN 1912, 1913 AND 1914. ${ }^{1}$}

\section{J. C. Arthur}

The present article is the thirteenth of a series of reports ${ }^{2}$ by the writer upon the culture of plant rusts, beginning in 1899 and completing sixteen consecutive years. The work for the three years covered by the present report has been done under the auspices of the Indiana Experiment Station, as a part of a research project supported by the Adams Fund.

The heaviest part of the work each year falls in April and May, and during this time the regular staff of the botanical department of the Experiment Station is supplemented in order to take care of the largely increased routine part of the work. In 1912 the assistant for the culture work was Mr. L. O. Overholts, a senior student of Miami University, Ohio, recommended by Dr. Bruce Fink; in I9I3 Mr. Ezra Levin, junior student with credits at the Agricultural College of Michigan, recommended by Dr. Ernst A. Bessey, was in charge; and in $1914 \mathrm{Mr}$. Carl B. Gibson, senior student of Wabash College, Indiana, recommended by Prof. H. W. Anderson, did the work.

A large number of correspondents have assisted as in previous years by sending culture material, often by supplying information from field observations, and sometimes by making special trips to secure additional material or search for cultural clues. To all such persons, and especially to those who have been to trouble and expense in response to the wishes of the writer for local aid, the most hearty thanks are accorded. Without the assistance of observers in the field, the work of studying the life histories of the rusts extending over the vast territory of North

1 Presented before the Botanical Society of America at the Philadelphia meeting, December 29, 1914.

2 See Bot. Gaz. 29: 268-276; 35: 10-23; Jour. Myc. 8: $5^{1-56} ; 10: 8-21$; II : $50-67 ; 12: 11-27 ; 13: 189-205 ; 14: 7-26 ;$ Mycol. 1: 225-256; $2: 213-240$; $4: 7-33,49-65$. 
America, many species of which are local, would proceed much more slowly.

An important aid in bringing together information regarding relationship of the rusts, and especially regarding obscure species, and in securing cultural material of critical forms, has been the excursions, often of considerable length, undertaken by the writer and members of his staff.

Early in April, I9I2, Dr. F. D. Kern and the writer paid a visit to Auburn, Ala., where in company with Prof. F. E. Lloyd, field conditions of Peridermium fusiforme and Puccinia angustatoides, the latter on Rynchospora, were studied.

In the latter part of May, I9I2, the writer and Mr. F. J. Pipal spent two days in LaGrange county on the northern border of Indiana, in a vain search for the alternate host of the Carex rust, Puccinia vulpinoidis.

An excursion on the last of May, 1912, was made to the coast of Maine by Mr. C. R. Orton and the writer. The localities visited were on the Isle au Haut, where the writer had found a number of imperfectly known rusts during several vacational sojourns. A station for the Puccinia on Carex maritima on Deer Isle was also visited. All previous observations had been made between July and October, and this long journey of over a thousand miles was for the purpose of seeking out probable aecial hosts under spring conditions. Upon the return journey, Mr. Orton stopped in Vermont and secured cultural material, especially forms on Carex.

Between June 17 and 20, I9r2, the writer made observations in company with Dr. J. J. Davis about Madison, Wis., and northward.

From the middle of July to the middle of August, I9I2, Dr. Kern and the writer traveled over a thousand miles through the high mountains of southern Colorado, going west through the middle of the state, and returning along the southern border. A week was spent in the wonderful valley at Ouray and some days at Pagosa Springs. Very helpful information was gleaned regarding grass rusts, and particularly of the leaf and stem forms which the older mycologists listed as Puccinia graminis and $P$. rubigo-vera. 
Three weeks of August, 1913, were spent in company with Mr. H. C. Travelbee, in northern Michigan in the vicinity of Leland. Here very abundant field confirmation was obtained of the correctness of the 1913 spring culture work in associating Puccinia vulpinoidis with aecia on Solidago, and material was secured for repeating the work.

Two days were profitably given in November, 1913, accompanied by Dr. F. D. Fromme, to an exploration of the Kankakee marshes in northern Indiana, and as much time in December following, accompanied by $\mathrm{Mr}$ : C. A. Ludwig, to a reconnoissance about French Lick in southern Indiana.

During February and the early part of March, 19I4, an extended trip by Dr. Fromme and the writer was made through the Southwest. Field work began at Denison, on the northern border of Texas. At Denton the localities made interesting to urediniologists by the extended field work of Mr. W. H. Long were visited. Stops on the way southward to Austin, and a divergence to Houston and Galveston, gave interesting results. Observations in the arid region were made principally at San Antonio and El Paso, Texas, the region about the Agricultural College, N. Mex., and at Douglas and Tucson, Ariz. At Tucson through the kindness and material assistance of Dr. D. T. MacDougal and his corps of investigators at the Desert Botanical Laboratory, the rust flora of the vicinity was examined, and a very important culture on Brodiaea was carried to completion.

The dominant ideas actuating the above mentioned geographical explorations are not so much those of the ordinary collector, to find new species, but rather those of the student, to secure additional knowledge of species already named but imperfectly known, and to gather facts bearing upon relationships.

To indicate the extent of the labor involved in securing the results recorded in this paper the following statistics are given. During the three seasons covered by this report, 380 collections with resting spores, and 68 with active spores were available, but scarcely one third of those with resting spores could be made to germinate. To test the germinating condition of the spores over 2500 drop cultures were made. Altogether 650 sowings were undertaken upon growing hosts and 84 infections obtained. 


\section{3}

Negative Results.-It has been customary in these reports to record failures to ascertain the alternate host, when sowings were made with spores known to be capable of germination and made upon plants that were in proper condition for infection. As the work progresses, and fewer species are left to be connected with alternate hosts, the need of such records diminishes, especially as more and :nore dependence is placed upon field observations for the clues to relationship. A few trials during the last three years with negative results appear to be sufficiently significant to be worthy of record at this time.

I. Puccinia McClatcineana Diet. \& Holw.-A collection of this species on Scirpus microcarpus (S. rubrotinctus), from Vaughns, Washington Co., N. Y., sent by Mr. Stewart H. Burnham, was used for sowings made April I, I9I4, on Chelone glabra, Hydrophyllum virginicum, $H$. Fendleri, Actaea alba, Dirca palustris, and Iris versicolor, all without infection.

This species has been confused with Puccinia angustata Peck. The name was first applied to a Californian collection thought to be on Scirpus syliaticus, but now determined as S. microcarpus. It is a common species along the Pacific coast on the last named host, known in one instance as far into the mountains as Belgrade near Bozeman, in southwestern Montana. It also occurs along the Atlantic coast on the same host (usually called S. rubrotinctus), being known from Nova Scotia to Delaware, and inland as far as Albany, N. Y. It was a collection of this species and host that was cited by Peck in establishing his Puccinia angustata, as on "Scirpus sylvaticum," from West Albany, N. Y. No clues to the identity of the alternate host have yet been secured.

2. Puccinia Cryptandri Ellis \& Barth.-A good teliosporic collection of this rust on Sporobolus cryptandrus was obtained by Dr. Fromme and the writer February 20, I9I4, at Mesilla Park, N. Mex., and sown March 20 on Spliaeralcea lobata, S. incana, and Callirhoe digitata. Eight days later it was sown on other plants of $S$. incana and $C$. digitata, and on Hibiscus militaris. Again on March 9, it was sown on Hydrophyllum Fendleri, Phacelia tanacetifolia, Thalictrum Fendleri, and Abronia umbellata.

A collection similar to the last was obtained on the preceding day, but thought at the time to be Puccinia tosta, which was 
sown April 17 on Lithospermum officinale, Aesculus glabra, Eleagnus argentea, Lepargyraea canadensis, and Doellingeria umbellata. It was sown again March 20 on Sphaeralcea lobata, Callirhoe digitata and $C$. involucrata. No infection was secured.

This is the first attempted culture of this species with teliospores, although once grown from amphispores. ${ }^{3}$ Most collections show only the amphisporic stage of the rust. No clue to the alternate host has yet been obtained.

3. Puccinia emaculata Schw.-This exceedingly common rust on Panicum capillare has been used in previous years for sowings on 26 different species of hosts with no infection. ${ }^{4} \mathrm{~A}$ careful morphological study shows that the species in its uredinial and telial conditions is very like Puccinia Pammelii Arth. ( $P$. Panici Diet.), occurring commonly on Panicum virgatum, whose aecia have been grown upon Euphorbia corollata. Since this fact was ascertained, attempts have been made to grow $P$. emaculata upon Euphorbia corollata. Telial material from the vicinity of Lafayette, Ind., was sown accordingly on April 28, I9r3, March 24, 31, and April 6, I9I4. Material collected by Dr. Fromme at Lakehurst, N. J., was sown May 8, I9I4, on both E. corollata and E. cyparissias. A collection from Lafayette was also sown March 31, I9I4, on Chelone glabra, and Dirca palustris, which had not previously been tried. All attempts were equally fruitless. It is hoped that some time a fortunate field observation may lead to the solution of the problem.

4. Uromyces Riyncosporae Ellis.-No satisfactory field clues to the alternate host of this species have yet been obtained. Morphological study has led to the suggestion, improbable as it may seem at first, that it can belong to the very common CarexAster-Solidago complex. To test this suggestion, material obtained by Dr. Kern and the writer at Auburn, Ala., was sown April 22, 1912, on Aster paniculatus, Solidago canadensis, and Hclianthus angustifolius. Another set of sowings was made on May 8 following upon other plants of the same three hosts, and on Ruellia strepens, and Apocynum cannabinum. No infection

3 Jour. Myc. 14: 20.1908.

4 Bot. Gaz. 35: 12. I903; Jour. Myc. 8: 52. 1902; 10: 10. I904; 12: 12. 1906; 13: 192. 1907; 14: 11. 1908; and Mycol. I: 230. 1909. 
was obtained. Cultures were attempted on Menyanthes and Decodon in 1907 , also without results. ${ }^{5}$

5. Uromyces Sporoboli E. \& E.-While on a visit to Mr. E. Bartholomew at Stockton, Kans., in August, I9II, the spot was pointed out where this rust on Sporobolus longifolius had been observed for several seasons following close upon a luxuriant development of an Aecidium on Allium reticulatum, as if the two might have genetic connection. Excellent material for testing the assumption was supplied the following spring, and a sowing was made April 29, I9I2, upon Allium reticulatum, and also on Malvastrum coccineum, Cassia chamaecrista, Baptisia bracteata, Apios tuberosa, Corydalis aurea, Zanthoxylum americanum, Phy'salis pubescens, Asclepias verticillata, Vagnera stellata, and Erigeron annuиs, all known to have aecia of uncertain connection, but without infection. ${ }^{6}$

Successful cultures SUPPLEMENTING PREvious WORK.-The facts derived from growing the following species of rusts supplement those obtained from previous cultures in this series or from cultures recorded by other American or European investigators. In some cases the additional information recorded is of as great value as if it were entered under the next heading of cultures not before reported. For instance, the hitherto accredited species, Puccinia vulpinoidea, $P$. Dulichii, and $P$. tosta, are reduced to synonymy, and in so far simplify the naming of collections, beside permitting of a clearer conception of the variation of specific characters. A few cultures were made which are not reported, as they add no new facts to those already established.

\section{Cultures of IgI2}

I. Puccinia Grossulariae (Schum.) Lagerh.-The following successful cultures were made, all being sown on Ribes $C y$ nosbati.

From Carex pubescens, Lafayette, Ind., sown April 20, showing pycnia April 29, and aecia May 9.

5 Jour. Myc. 14: 12. 1908.

${ }^{6}$ For previous attempts see Bot. Gaz. 35: II. I903; and Mycol. I : r3. I9I2. 


\section{Artiun: Celtures of Uredineae}

From Carex crinita, St. Anne de Bellevue, Quebec, sown May 8, showing pycnia May 16, and aecia May 24.

From Carex arctata, St. Anne de Bellevue, Quebec, sown May 8, showing pycnia May 22, and aecia May 27.

From Carex tenuis, St. Anne de Bellevue, Quebec, sown May 13, showing pycnia May 22, and aecia May 27.

In the report of cultures for $1910^{7}$ the status of the name $P$. albiperidia, as representing a distinct species of Carex-Ribes rust, was discussed, but left somewhat unsettled. It was, however, thought to belong to a form possessing urediniospores with one basal pore, while the more common form on the same hosts, $P$. Grossulariae, has urediniospores with three equatorial pores. Subsequently Mr. C. R. Orton went over the material involved, including the type of $P$. albiperidia, and concluded ${ }^{8}$ that this name should be a synonym of $P$. Grossulariae, and that the form having urediniospores with one basal pore is entitled to be considered a distinct species to which he gave the name $P$. uniporula, a species correlated with Uromyces uniporulus Kern, the aecia of both species being unknown.

To gather further information I have had single sori removed from the type collections of both species of Puccinia involved, and have had the spores of each sorus separately counted by using a mechanical stage. The results are given in the following table. The type of $P$. albiperidia is on wintered-over leaves, having been gathered April 30, I90I, at Lafayette, Ind., and provides few urediniospores, while that of $P$. uniporula was gathered August 20, 1910, at London, Ontario, and gives a fair number of urediniospores. Both types are on Carex pubescens. As usual when urediniospores are taken from mature telial sori, many of the spores are not in condition to show the pores. When the pores could not be ascertained with fair certainty, even after using lactic acid or chloral hydrate with iodine, the spores have been classed as uncertain. It was also necessary to take the number of cells in the teliospore into account, as Carex pubescens also bears Uromyces uniporulus, chiefly distinguishable by the teliospores.

7 Mycol. 4: 13-15. 1912.

8 Mycol. 4: 200, 201. 1912. 
SPORES FROM TyPe Collections of Puccinia albiperidia and $P$. uniporula: EACH SORUS GIVEN SEPARATELY.

\begin{tabular}{|c|c|c|c|c|c|c|}
\hline \multicolumn{2}{|c|}{$\begin{array}{l}\text { Number of } \\
\text { Sorus }\end{array}$} & $\begin{array}{l}\text { Teliospores } \\
\text { with I-cell } \\
\text { (Uromyies) }\end{array}$ & $\begin{array}{l}\text { Teliospores } \\
\text { with 2-cells } \\
\text { (Puccinia) }\end{array}$ & $\begin{array}{c}\text { Urediniospores } \\
\text { with One Basal } \\
\text { Pore }\end{array}$ & $\begin{array}{l}\text { Urediniospores } \\
\text { with Three } \\
\text { Equatorial } \\
\text { Pores }\end{array}$ & $\begin{array}{l}\text { Uredinio- } \\
\text { spores } \\
\text { with Pores } \\
\text { Uncertain }\end{array}$ \\
\hline \multirow{7}{*}{$\begin{array}{l}\text { हैँ } \\
\text { हैँ } \\
\text { हैँ }\end{array}$} & $\mathbf{I}$ & 0 & Not counted & 0 & 0 & 0 \\
\hline & 2 & 0 & 231 & 0 & o & 0 \\
\hline & 3 & 0 & 317 & o & o & o \\
\hline & 4 & 0 & 363 & 3 & 0 & 1 \\
\hline & 5 & 0 & 886 & 4 & o & 2 \\
\hline & 6 & I & 327 & $\circ$ & 1 ? & 4 \\
\hline & 7 & 29 & 1325 & 0 & 0 & 3 \\
\hline \multirow{4}{*}{ ¿ัँ } & 8 & $3 I_{4}$ & 3 & 0 & I? & o \\
\hline & 9 & 422 & I & 0 & o & 0 \\
\hline & I0 & 697 & 2 & 0 & 0 & I \\
\hline & II & Not counted & 0 & 0 & o & 0 \\
\hline \multirow{5}{*}{ 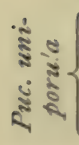 } & 12 & 0 & 142 & I 7 & 2 & 5 \\
\hline & 13 & 3 & 853 & 4 & $\mathbf{I}$ & 5 \\
\hline & 14 & 3 & $87 \mathrm{I}$ & 3 & o & I \\
\hline & 15 & 4 & 1455 & 5 & 0 & I \\
\hline & 16 & 5. & I9 & 12 & I & 7 \\
\hline
\end{tabular}

Taking first the two columns of teliospores in the above table, it may be assumed that when a few only of either one- or twocelled teliospores occur in a sorus they are to be considered as incidental, possibly mesosporic. We may exclude from our present consideration four sori ( 8 to II incl.) from the type of $P$. albiperidia, as belonging to another species, Uromyces uniporulus, in termixed on the same leaf blades.

Of the remaining seven sori taken from the type of $P$. albiperidia, two of them (numbers 4 and 5 ) show a few urediniospores with one basal pore, and one sorus (number 6) shows one urediniospore with apparently three equatorial pores, while all others give no urediniospores whose pores could be made out with certainty.

Of the five sori ( 12 to 16 incl.) taken from the type of $P$. uniporula all show a number of urediniospores with one basal pore, and in addition three of the sori. (numbers 12, 13, and 16) show urediniospores with three equatorial pores, as well as a number of spores whose pores could not be located. It is curious to note that in this type material of $P$. uniporula about one tenth of the urediniospores possess equatorial pores, and that these spores are intermixed in the same sori with the one-pored spores.

So far as the morphological evidence goes, there appears to be 
no absolute difference between the types of $P$. albiperidia and $P$. uniporula. But $P$. albiperidia has been cultured on Ribes, producing aecia that can not be distinguished from those Carex rusts which show urediniospores with equatorial pores only. Whether aeciospores grown from $P$. albiperidia material would reproduce urediniospores, when sown back on a suitable Carex, with only three-pored or only one-pored urediniospores, or with sori containing a mixture of the two, is yet to be demonstrated. In the meantime, it seems best to use the name $P$. albiperidia as representing a form with aecia on Ribes, and synonymous with P. Grossulariae, while $P$. uniporula can be retained for such collections as show a preponderence of one-pored urediniospores. It is interesting to note in this connection that in Europe no Carex rust has yet been found agreeing with the uniporulate forms here discussed.

The essential specific unity of all Carex-Ribes rusts in both America and Europe was the conclusion reached by Dr. H. Klebahn in 1907. Dr. Klebahn's extended cultural work on this group of rusts began in 1892, and resulted in the separation of five species. In 1904 and 1906 he studied the behavior of American material grown from teliospores transmitted by the writer. Taking into account both European and American material, he came to the conclusion ${ }^{9}$ that the six described species of CarexRibes rusts were biological forms of one collective species, for which he suggested the name, Puccinia Ribesii-Caricis. This conclusion is upheld by the above study, although an earlier name is preferred for the species.

2. Puccinia Caricis-Asteris Arth. ( $P$. Caricis-Solidaginis Arth.) - Five successful cultures of this rust were secured. They are as follows:

Teliospores from Carex sp., London, Ontario, sown April ro on Aster sp., showing pycnia April 16, and aecia April 27.

Teliospores from Carex sp., Lafayette, Ind., sown April iI on Aster sp., showing pycnia April 23, and aecia April 29.

Teliospores from Carex retrorsa, St. Anne de Bellevue, Quebec, sown May 14 on Aster paniculatus, showing pycnia May 22, and aecia May 27.

Teliospores from Carex scoparia. St. Anne de Bellevue, Quebec, sown May 13 on Aster paniculatus, showing pycnia May 22, and aecia

- Klebahn, Zeits. Pflanzenkr. 3: 134. 1907. 


\section{$70 \lcm{229}$}

\section{Mycologia}

May 27; also sown same date on Euthamia graminifolia, showing pycnia May 22, at aecia June 4.

The significant thing about these cultures is that the material from Care.x scoparia, which was sent by Mr. W. P. Fraser, grew on both Aster and Euthamia. The rust on this species of Carex, as represented in the herbarium, was for a long time considered sufficiently diverse morphologically to constitute a distinct species. Two years ago material on Carex scoparia from Maine was cultured on Euthamia, ${ }^{10}$ but did not grow on Aster paniculatus or Solidago canadensis. This year sowings were made on the three hosts named and results obtained on two of them. It was pointed out in the discussion of the results two years ago that the Aster-Solidago-Erigeron group of Carex rusts probably constitutes a single species with a number of more or less defined races. The same view has been expressed elsewhere. ${ }^{11}$ Numerous confirmatory facts of diverse nature have been accumulating, until it seems advisable to adjust the nomenclature to accord with present knowledge.

This species is one of the most common forms of rust in North America. It evidently is less abundant in South America and in the eastern hemisphere. The morphological study of similar European forms, rated as species, discloses some that undoubtedly are to be classed in the same category with the American group. Without taking space to record the evidence, the conclusion has been reached that the most available name for the American and European constituents of the species here represented, but possibly not the oldest one, is Puccinia extensicola Plowr. This name was founded on telial material from Carex extensa, obtained at Norfolk, England, and cultured on Aster Tripoli, and is in every way comparable with the Carex-Aster forms of America. ${ }^{12}$

3. Puccinia angustata Peck.-Teliospores on Scirpus atrovircns, collected at Lafayette, Ind., by L. O. Overholts, were sown

10 Mycol. 4: 15. I912.

11 Arthur, The physiologic aspect of the species question. Amer. Nat. 42 : 246.1908.

12 For previous American cultures of this specific group, see Bot. Gaz. 35: I5, 21. I903: Jour. Myc. 8: 53, 54. 1902; II: 58 . I905: 12: 15. I906; 14: 13. 1908; Mycol. I: 233. I909; 2: 224. 1910; and 4: 15, I6. 1912. 
May 9 on Lycopus americanus, giving rise to pycnia May I6, and aecia May 24. Another collection believed to be the same rust and on the same host, collected at London, Ontario, by J. Dearness, was sown May 13 on L. Americanus, giving rise to pycnia May 20, and aecia Nay 27. Corresponding cultures have been made many times before. ${ }^{13}$ The rust is very common throughout the eastern United States, especially northward, but has not been seen in the Rocky mountain region or on the Pacific coast. Professor Peck based the name, Puccinia angustata, which was published in the Bulletin of the Buffalo Society of Natural History, volume I, page 67 , July, 1873 , upon material from "leaves of Scirpus sylvaticum and S. Eriophorum; West Albany and Watkins, September." Upon examination of type material, it transpires that the collection on "S. sylvaticum" was made at Watkins, N. Y., and that on S. Eriophorum at West Albany, N. Y., and furthermore, that of the two hosts cited only S. Eriophorum, collected at Watkins, N. Y., although the second one mentioned, bears teliospores that correspond to the description. The other collection on "S. sylvaticum," found to be in reality S. microcarpus (S. rubrotinctus), bears a distinctly different form of teliospore, and must be considered to belong to some other species than $P$. angustata. The type of P. angustata Peck is, therefore, the collection in the herbarium of the New York State Museum, at Albany, N. Y., collected in September [1871 ?], at Watkins, N. Y., on Scirpus Eriophorum, by Prof. C. H. Peck. Thanks are due to Prof. Peck for the loan of the type material and for much assistance in ascertaining numerous facts connected therewith.

4. Puccinia Ellisiana Thüm.-A collection on Andropogon sp., made by Dr. J. F. Brenckle, at Kulm, N. D., was used to sow, April 9, on Viola cucullata, $V$. Nuttallii, $V$. primulaefolia, Laciniaria punctata and Lithospermum angustifolium, with infection only on the two first named species of Viola. In both cases pycnia began to show in abundance May 8, and aecia May 12.

A number of vain attempts have been made in previous

13 For previous cultures see Bot. Gaz. 29: 273. 1900; Jour. Myc. 8: 53. 1902; II: 58.1905 ; 13: 196. 1907; 14: 14. 1908; Mycol.1: 234. 1909; 4: 17 and 54. 1912 . 
years $^{14}$ to culture this rust, thirty-five species of hosts having been used other than those used this year. Only once was a plant of Viola used, $V$. striata, a caulescent species on which such aecia have not yet been found, and are not very likely to occur.

The successful cultures were inspired by field observations by Dr. Brenckle, who sent us material with which to test his prediction. In addition to Dr. Brenckle's opinion there was also at hand the opinion of Mr. C. R. Orton, at that time working on the rusts in my laboratory, which was drawn from a study of correlation between this species and Uromyces pedatatus, in a paper read December 28, I9II, but not published until later, ${ }^{15}$ the latter species having its aecia on acaulescent violets. Since that time Mr. W. H. Long has published ${ }^{16}$ extended studies, both cultural and morphological, with important bearings which can not be taken into consideration in this connection.

5. Puccinia Stipae Arth.-Two collections with teliospores on Stipa comata, gathered by Mr. E. Bethel, from different spots at Boulder, Colo., were used for cultures. One was sown May I5 on Senecio lugens, S. spartioides, ${ }^{17}$ Chrysopsis villosus, Grindelia squarrosa, Gutierrezia Sarothrae, and Solidago mollis, all considered probable hosts for the aecia. Infection occurred only on Gutierresia Sarothrae, showing pycnia May 22, and aecia May 27, both in abundance.

The other collection was sown May I7 on the same set of hosts with infection only on Senecio spartioides, showing numerous pycnia May 23, and aecia June I.

This species has previously been cultured ${ }^{18}$ on Aster multiflorus, A. ericoides, A. Norae-Angliae, Solidago canadensis, Grindelia squarrosa, and Senecio lugens. The present study adds two

14 See Jour. Myc. 14: 10. I908; Mycol. I: 231. I909; 2: 220. 1910; and $4:$ 9. I9I 2.

15 Mycol. 4: 199, 200. pl. 70, figs. 5 and 6. 1912.

16 Notes on three species of rusts on Andropogon, Phytopath. 2: 164-171. August, I912; and Influence of the host on the morphological characters of Puccinia Ellisiana and Puccinia Andropogonis, Jour. Agric. Research 2: 303319. July, 1914.

17 The same host that was erroneously called $S$. Douglasii in report for 1910. Mycol. 4:9, II. I9I2.

18 See Jour. Myc. II: 63. I905; and Mycol. 4: 19. I912. 
aecial hosts to the list previously known, and further strengthens the view that the species consists of a number of loosely defined races.

6. Puccinia Agropyri E. \& E.-Three collections on Elymus canadensis from two widely separated and very different habitats were successfully cultured. One collection made by $\mathrm{Mr}$. E. Bethel at Boulder, Colo., from plants on which he had previously placed leaves of Clematis ligusticifolia covered with aecia, brought from thirty miles distant, was sown April 27, on $\mathrm{Cle}$ matis ligusticifolia, C. Douglasii, Anemone cylindrica, Delphinium Geyeri, and Thalictrum Fendleri, all believed to be probable hosts of this rust, and on Phacelia heterophylla, Hydrophyllum capitatum, H. Fendleri, and Onosmodium occidentale, which have been suspected from field observations to belong to the list of hosts. Infection only occurred on Clematis ligusticifolia, showing pycnia May 8, and aecia May 20.

Another collection by Mr. Bethel from plants growing with aecia-bearing Clematis lingusticifolia, at Boulder, Colo., was sown May I4, on the same nine species of hosts, with infection only on Clematis ligusticifolia, showing pycnia May 2I, and aecia May 29.

The third collection by Dr. Brenckle from Kulm, N. Dak., was sown on Clematis ligusticifolia, C. Douglasii, C. virginiana, Anemone cylindrica, Delphinium sp. from Colorado, Thalictrum Fendleri, T. alpinum, Aquilegia caerulea, and A. flavescens, all belonging to a quite possible group of hosts, and on the outlying hosts, Phacelia heterophylla, Hydrophyllum Fendleri, Onosmodium occidentale, and Elaeagnus argentea. Infection was obtained only on Anemone cylindrica, showing a few pycnia May 20, but without maturing aecia.

Another collection of the same rust on Agropyron Smithii (host determined by Prof. A. S. Hitchcock), collected by the writer at Pueblo, Colo., was sown April 29, on Clematis ligusticifolia, C. Douglasii, Anemone cylindrica, Delphinium sp. from Colorado, Thalictrum Fendleri, Hydrophyllum capitatum, H. Fendleri, and Onosmodium occidentale, with infection only on the first named. The pycnia began to show May 8 and aecia May I7. 
Cultures from Elymus on Clematis ligusticifolia are now reported for the first time. It has seemed quite probable from field observations that the aecia occurring on this host in great abundance throughout the Rocky Mountains were probably connected with telia on other hosts than Agropyron, where they have usually been assigned in this country and Europe, but this is the first direct proof by cultures. In 1904 a rust on Bromus from Iowa, Indiana, and Wisconsin, believed to be Puccinia tomipara Trel., was grown on Clematis virginiana. In a discussion of the results $^{19}$ it was considered that the aecia were the form known as Aecid. Clematitis Schw., and distinct from the form in the Rocky Mountains, going to telia on Agropyron. The latter form, called Aecid. Clematidis DC., was grown in $1907^{20}$ from Rocky Mountain material on Agropyron, but on the eastern host $C$. virginiana, no plants of $C$. ligusticifolia being available at the time. This was considered a demonstration that the form known and cultured in Europe as P. Agropyri E. \& E., on Agropyron, is identical with the western form, but distinct from the eastern BromusClematis rust.

In 1908 a rust on Bromus from the Rocky Mountains was grown on Thalictrum dioicum with success. The same season a similar subepidermal rust on Agropyron from the western mountains was grown on Aquilegia. These two forms were considered to represent distinct species and were named respectively $P u c$ cinia alternans and $P$. obliterata. ${ }^{21}$

The first cultural study of this group of subepidermal rusts began in 1903 with a supposed culture of Dirca aecia on Bromus, ${ }^{22}$ an error which was rectified in the report of cultures the year following. From that time to the present morphological studies, field observations, and careful cultures have multiplied until now there seems to be no further doubt that this group of subepidermal forms, passing under various names, represents only one species, but a species broken up into a number of races of considerable

19 Jour. Myc. II : 62-63. I905; also 13: 197. I907; and Mycol. I: 236. r 909.

20 Jour. Myc. 14: 15. I908.

21 Mycol. I: 248-251. 1909; also 2: 225. I910.

22 Jour. Myc. Io: 19. 1904; also II: 62. I905. 
fixity. The telia are on Agropyron, Elymus, and Bromus chiefly and the aecia on Clematis, Thalictrum, Aquilegia, Anemone, and probably other Ranunculaceous hosts, and possibly on some hosts of other families.

7. Peccinia monoica (Peck) Arth.-In the report of cultures for $19 \mathrm{II}^{23}$ record was made of sowings of teliospores from Trisetum subspicatum made June 20 upon two plants of Arabis (grown from Colorado seed), one plant of which indicated infection by a pathological change into a glomerate mass of rosettes, somewhat paler than normal. In this condition the plant passed the winter. Early in spring it began to send up a half dozen or more shoots instead of the usual single shoot of normal plants. Pycnia first were seen March 23, 1912, scattered over the considerably drawn shoots. Before there was time for the aecia to mature the plant accidentally died.

Freshly gathered plants of an Arabis bearing aecia, obtained May I3 at Palmer Lake, Colo., were received from Mr. Bethel, and aeciospores from them sown May 18 on leaves of Koeleria cristata and Trisetum subspicatum. Infection occurred only on the Koelcria, uredinia first being noticed June 18 , and telia June 24 .

There is no present need of adding to the general discussion of this species given in the last report of cultures. ${ }^{24}$ We have now grown the rust from both aeciospores and teliospores, and shown that it occurs on both Trisetum and Koeleria, with some indication of biological races.

8. URomyces Perigynius Halst.-A collection on Carex intumescens, made by Dr. Charles E. Fairman at Lyndonville, N. Y., was sown April 24, on Aster paniculatus, Solidago canadensis, Erigeron annuus, Euthamia graminifolia, and Onagra biennis. On May 7 pycnia began to show in great abundance on the Aster, followed on May io by aecia. On the Solidago a few pycnia appeared May 8, but no aecia developed, although the host plant was in good condition.

In former cultures ${ }^{25}$ material on this host from Nova Scotia produced infection on Aster, but not on Solidago. Material on

28 Mycol. 4: 60. 1912.

24 Mycol. 4: 59. 1912.

25 See Jour. Myc. 10: 15-17. 1904; Mycol. 4: 21, 2x. 1912. 
other hosts from Maine and Indiana produced strong infection on Solidago, and in one case a sparing infection also on Aster. In the first culture report on the species, the close resemblance between this species and the parallel form under Puccinia, that we are now calling $P$. extensicola, was pointed out, and in the second report the evidence of well defined biological races was adduced. Both of these points are further emphasized by the cultures here reported.

In this connection an error should be corrected in the report of cultures for 1910. Quite anomalous results ${ }^{26}$ were obtained in that year by sowing material of Puccinia quadriporula Arth. from Carex Goodenowii from the type locality, upon Aster paniculatus. It was at that time pointed out that the resulting aecia were indistinguishable from those of $P$. Caricis-Asteris Arth. A careful re-examination of the culture records has revealed the fact that the sowing on April 26, $1910,{ }^{27}$ was immediately preceded by a very successful sowing of Uromyces perigynius on another plant of the same species of Aster. The inference is that the supposed result from the spores of $P$. quadriporula in reality came from stray spores of $U$. perigynius accidentally intermixed during the operation, and do not represent a culture of $P$. quadriporula.

Furthermore, a careful and extended morphological study of a number of collections of $P$. quadriporula, made in different years from the type locality and its vicinity, leave no doubt that the form should be placed under P. Grossulariae, a Carex rust having aecia on Ribes. The four-pored feature of the urediniospore, from which the name is derived, is found to be no more marked than in some other collections proven to be a part of that species.

9. Uromyces Junci (Desm.) Tul.-It was stated in the report of cultures for $19 \mathrm{IO}^{28}$ that both Mr. Bethel and Dr. Brenckle held the opinion that this species in some one of its forms would be found to have aecia on Ambrosia psilostachya. Both gentlemen provided material for a test the present season, which verified their prediction, as the following record of cultures shows. The telial host in each instance was Juncus balticus.

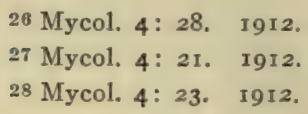


Arthur: Cultures of Uredineae 236

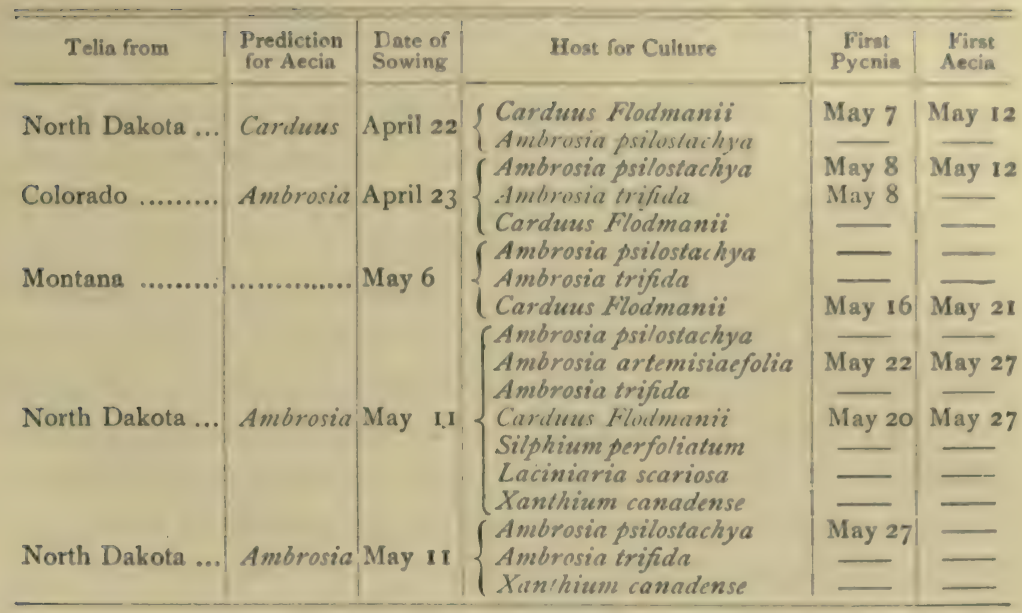

The three collections sent by Dr. Brenckle from Kulm, N. Dak., bore out the prediction that he had based upon field observations. One of the collections grew upon both Ambrosia and Carduus, indicating that the races are not invariably fixed. The collection sent by Mr. Bethel from Boulder, Colo., also bore out the prediction which he had based on a field observation. No suggestions came with the collection sent by Mr. Vasku from Nihill, Mont. As stated in the North American Flora (7: 238. 1912), only Carduns has heretofore been proven by cultures in this country to be a host to this species, although both Ambrosia and Arnica have been considered to be hosts, a conclusion derived from morphological and field studies. ${ }^{29}$

ro. Uromyces acuminatus Arth.-A collection made by Mr. Bethel at Boulder, Colo., on Spartina Michauxiana, showing the characteristic slender, acuminate teliospores to which this name has been applied, was suspected from field observations to belong to aecia found on Collomia. Sowings were made April 29 on Collomia linearis, Steironema ciliatum and S. lanceolatum. Infection resulted only on Collomia, showing a great abundance of pycnia May 8, and aecia May 12.

This culture adds one more host experimentally proven to belong to this species, although it had been associated with the spe-

29 For previous cultures see Jour. Myc. 14: 12. 1908; Mycol. 2: 220. 1910; 4: 22. 1912. 
cies and with this particular race from morphological and field studies. ${ }^{30}$

ii. Gymnosporangium Nelsoni Arth. (G. durum Kern).Galls of this rust a half inch in diameter from Juniperus scopulorum, gathered by $\mathrm{Mr}$. Bethel at Cimarron, Colo., were used for sowing. May 25 on Amelanchier canadensis and Crataegus punctatus. Infection occurred only on Amelanchier, showing abundant pycnia June 4, but giving only a few aecia, first noticed July $17 \cdot{ }^{31}$

12. Gymnosporangium Betheli Kern.-A collection of galls on small branches of Juniperus scopulorum, made by $\mathrm{Mr}$. Bethel at Plainview, Colo., were used to sow, June 4, on Crataegus Pringlei, giving rise to pycnia June $\mathrm{I} 4$, and aecia July $\mathrm{I} 7 \cdot^{32}$

i3. Gymnosporangium gracilens (Peck) Kern \& Bethel.-A collection on Juniperus utahensis, made by $\mathrm{Mr}$. Bethel at Glenwood Springs, Colo, was used for sowing on Philadelphus coronarius, giving an abundance of pycnia May 3I, and aecia June I4. Another sowing was made at the same time on a horticultural form closely related to $P$. coronarius, imported from France, $P$. Keteleerii, which resulted in a luxuriant growth of pycnia May 30, and aecia June 22. These results confirm previous work. ${ }^{33}$

\section{Cultures of I9I 3}

i4. Puccinia albiperidia Arth.-A collection made by $\mathrm{Mr}$. L. S. Orton at Walden, Vt., on a narrow-leaved Carex, and communicated by Mr. C. R. Orton, was used to sow, May 29, on Ribes Cynosbati, giving abundant infection with pycnia showing June 6 , and aecia June 20. The rust was labelled by Mr. Orton $P$. uniporula, and our examination confirms this view, many urediniospores having been seen with one basal pore and none with equatorial pores. This does not, however, preclude the possibility of the infection coming from the three-pored form, which may be intermixed with the other, and the species is listed accordingly

30 See North American Flora 7: 231. 1912. For previous cultures see Mycol. 4: 29. I912; also Fraser in Mycol. 4: 186. I912.

31. For previous cultures see Mycol. 4: 6r. I9r2.

32 For previous cultures see Jour. Myc. 14: 23. 1908; Mycol. I: 240. $1909 ; 2$ : 230. 1910; 4:25. 1912.

33 For previous cultures see Mycol, 4: 63. I9r2. 
as in the similar culture work of 1912 , discussed above under number $\mathrm{r}$.

15. Puccinia vulpinoidis D. \& H.-A collection of this rust on Carex vulpinoidea (host determined by Dr. Theo. Holm) made by Mr. Overholts at Elkton, Ohio, was used to sow April I7 on Aster paniculatus, A. Drummondii, Solidago canadensis, S. glaberrima ( $S$. missouricnsis of most manuals), $S$. Rugosa, and $S$. mollis. There was no infection of Asters, but a most abundant infection of the four species of Solidago, pycnia showing in each case April 27, and aecia May 7.

Puccinia vulpinoidis has been considered a distinctive and easily recognized species on account of the covered telial sori. A careful morphological study, chiefly by Dr. F. D. Kern, had shown however, that aside from this character the spore structure and range of hosts agree with $P$. Caricis-Solidaginis, or as we now say, $P$. extensicola, and to this morphological study was due the suggestion which led to the above successful cultures. The permanently covered telial sorus must be considered in the light of this study to be associated with the structural peculiarities of the host, and not a character to be used without qualification.

i6. Gymnosporangium clavariaeforme (Jacq.) DC.-Material on Juniperus sibirica, sent by Mr. Bethel from Tolland, Colo., was sown May 2I on Crataegus cerronus and gave rise to abundant pycnia June I, but no aecia matured. ${ }^{34}$

17. Peridermium fusiforme Arth. \& Kern.-Through the kindness of Dr. F. A. Wolf of Auburn, Ala., typical material of this striking rust was received, gathered from a grove of Pinus taeda, which Dr. Kern and myself had visited in April, I9I2, and in which this form of Peridermium is very abundant.

The first collection, sent March 22, I9I3, was from a main stem an inch in diameter, the fusiform gall being one and a half inches in diameter at the middle, and six inches long. It was sown March 24 on two plants of Quercus rubra. Uredinia began to appear sparingly on one plant by April 3, but failed to appear on the other, although telia developed on both plants April I4, in ample and perfect development.

34 For previous cultures see Jour. Myc. 14: 19. 1908; Mycol. 1: 239. $1909 ; 4: 24 . \quad 1912$; and $4: 56.1912$. 
The second consignment was received April 5, I9r3, consisting of a much larger gall, three inches in diameter by six inches long, but less typical in appearance. This material was sown April 6 on Quercus rubra and Q. Phellos. On the former, uredinia began to appear April I4, and on the latter April I8, followed by telia in both cases April 28.

This result shows without question that the form known under the name of Periderminm fusiforme is identical specifically with $P$. Cerebrum, both being the aecial stage of Cronartium Quercus. This cultural result is briefly referred to by Dr. Kern in Mycologia 6: II2, I35. I9I4. The non-appearance of the repeating stage in one case is an interesting phenomenon apparently connected with some condition of the host.

i8. Peridermium carneum (Bosc) Seym. \& Earle.-Leaves of Pinus taeda bearing this rust were gathered by Prof. P. H. Rolfs, at Gainesville, Fla., February I2, I9I3, and two days later were used by use to make a sowing on Vernonia fasciculata. Uredinia began to appear in abundance on March 3. Another collection of the rust was gathered by Mr. H. E. Stevens from Pinus palustris in the vicinity of Gainesville, Fla., on March I. This material was from small plants in the open, over which leaves of Ipomoea pandurata well covered with Coleosporium Ipomoeae had been placed the previous fall. The field condition appeared to warrant the inference that the pine aecia were derived from the Ipomoea telia. A sowing of the material was made March Io on Vernonia fasciculata, but no plants of Ipomoea were available for a culture. Uredinia appeared on the Vernonia in abundance on March 29, and in the typical form of Coleosporium Vernoniae.

This result does not preclude the possibility that Coleosporium Ipomoeae is a form of C. Vernoniae, but judging from the microscopic appearance of the urediniospores, that species is more likely to be a form of $C$. Solidaginis than of C. Vernoniae.

\section{Cultures IN I9I4}

19. Puccinia extensicola Plowr.-A collection of the form known as $P$. vulpinoidis, collected by Mr. Travelbee and the writer 
on Carex vulpinoidea, at Leland, Mich., Aug. 26, 1913, was used to sow April 2, on Solidago canadensis and Aster paniculatus. Abundant infection occurred on the Solidago, pycnia showing April II, and aecia April 20, but the Aster remained free. The collectors found in many instances old aecia on $S$. canadensis in the field, intermixed with rusted Carex vulpinoidea. The inference from field observation, and also the cultural work of last year as recorded above under number 15 , is confirmed by the culture.

A collection of $P$. Dulichii.Syd, on Dulichium arundinaceum, gathered Jan. 17, I9I4, at Gainesville, Fla., by Mr. H. E. Stevens, was accompanied by young aecia on a species of Aster. This association suggested that they might be genetically connected. A sowing from the Dulichium material was made, Jan. 22, on Aster Drummondii, A. paniculatus, and on an undetermined Aster, which had been obtained from a field near New Orleans, La., also on Solidago canadensis and Senecio obovatus. Another sowing from the same material was made, Jan. 3 I, on the same three species of Aster, and on $A$. Treedyi. The only infection was a sparing production of pycnia on Solidago canadensis, showing Feb. 3, which did not continue into aecia. As soon as this result was noticed, another sowing from the same material was made, Feb. 4, on Solidago canadensis, which resulted in an abundant infection, showing pycnia Feb. 16, and aecia Feb. 25. From this result, together with a careful microscopic study of herbarium material, it is inferred that $P$. Dulichii is a part of the common $P$. extensicola, although the telial host is not a Carex. It is the first time that any Carex rust has been traced to a telial host outside of the genus Carex.

20. Puccinia tosta Arth.-A collection was made by Dr. Fromme and the writer at Mesilla Park, N. Mex., on what was thought at the time to be Muhlenbergia Porteri, but which later proved to be the very similar appearing Sporobolus asperifolius. Thinking that it was $P$. Muhlenbergiae, known to have its aecia on malvaceous hosts, it was sown, March 20, on Callirhoe involucrata, C. digitata, and Sphaeralcea incana. Infection was obtained only on the last host, pycnia showing March 27, and aecia April 3, both in great profusion. Another sowing was at once 
made of the same material on S. lobata, C. digitata, Hibiscus militaris, and Malvastrum coccineum, with infection only on the Sphaeralcea, pycnia showing April 6, but the aecia being destroyed by aphis before maturing.

Another collection of identical appearance was made five days later than the one above, at Ysleta, Texas, a few miles from El Paso. This was sown, March 28, on two plants of S. lobata, on $C$. digitata, and $H$. militaris. Both plants of Sphaeralcea gave infection, showing pycnia April 6, but resulting in few aecia, owing to accident. Another sowing from the same collection was made, May 2, on Napaea dioica, without infection.

Putting the above cultural results from $P$. tosta, with the gross appearance and subsequent microscopic study, and comparing with similar data from $P$. Muhlenbergiae, there appears to be no ground upon which to keep the two forms separate. The fact that the telial hosts belong to two genera of grasses is not in this case a difference of importance, as Sporobolus and Muhlenbergia intergrade, and are kept separate upon technical grounds. The previous cultural studies ${ }^{35}$ of $P$. Muhlenbergiae have indicated that the species is a complex of races. It has been grown on Hibiscus militaris and Callirhoe involucrata, but the similar aecia on Napaea, Malrastrum, and Sidalcea have not yet been grown, although attempted, the failure believed to be due to a lack of the proper racial telia. The above is the first successful culture with material on Sporobolus, although previous attempts ${ }^{36}$ have been made.

Hereafter it will be considered advisable to treat $P$. tosta as a synonym of $P$. Muhlenbergiae.

2i. Puccinia Agropyri E. \& E.-A collection of this rust on Elymus virginicus was made by Dr. Fromme and the writer on Feb. I3, 19I4, at Austin, Texas, and at the same time the observation was made that Clematis Drummondii, not then in leaf, was in the same spot, and abundant in the vicinity. Dormant roots of this wild Clematis were secured, and later grown for the culture work.

35 See Jour. Myc. II : 51. 1905; 13: 192. 1907; Mycol. I: 251. 1909; 2: 226. I910; and $4: 18.1912$.

36 See Jour. Myc. 10: 10. 1904; 12: 12. 1906; Mycol. 4: 10 and 52. I9r 2. 


\section{Arthur: Cultures of Uredineae $242^{83}$}

A sowing of telia was made April I on Clematis Drummondii, C. Douglasii, C. virginiana, Aquilegia flavescens, A. canadensis, Thalictrum Fendleri, and $T$. dioicum. Abundant infection occurred on the first named host, but on no others, pycnia appearing April 5, and aecia April I8.

The results are in accord with the cultures of 1912 , reported above under number 6 , but indicate another race not met with before.

22. UROMYCES PERIGYNIUS Halst.-A collection of this species on Care. $x$ tribuloides made at French Lick, Ind., by Mr. Ludwig and the writer, was sown April I on Aster paniculatus, A. Drummondii, A. Tweedyi, Solidago canadensis, S. rugosa, and Euthamia graminifolia. Infection was secured only on Aster Tweedyi, and then so sparingly that it was overlooked until April 8, when the aecia were observed. Cultures for I9I2 are reported above under number 8.

This species of rust from other Carex hosts has previously been been grown ${ }^{37}$ on two other species of Aster, and five species of Solidago.

23. Uromyces Scirpi (Cast.) Burr.- Material on Scirpus fluviatilis, sent by Mr. E. T. Bartholomew from Madison, Wis., was sown April 22 on Sium cicutaefolium, giving rise to a few pycnia May 5, but without further development. Another similar sowing April 24 gave rise to an abundance of pycnia May 5, and aecia May II.

The former cultures ${ }^{38}$ with American material have been on Cicuta maculata.

24. Gymnosporangium nidus-Avis Thax.-Telial material on Juniperus virginiana, gathered by Dr. Fromme at Woods Hole, Mass., was sown May II on Amelanchier vulgaris, giving rise to pycnia May 19, and a great abundance of aecia June $20 .{ }^{39}$

25. Gymnospornngium Botryapites (Schw.) Kern.-Telial material on Chamaecyparis thyoides sent by Dr. Fromme from Lakehurst, N. J., was sown May 6 on the leaves of Amelanchier canadensis and Aronia arbutifolia, with no infection on Aronia,

37 Jour. Myc. I0: 15. 1904; and Mycol. 4: 32. 1912.

38 Jour. Myc. 13: 199. 1907; 14: 17. 1908; and Mycol. I: 237. 1909.

39 For previous cultures see Jour. Myc. 14: 19. 1908; Mycol. 2: 230. $1910 ; 4: 25$ and 56.1912 . 
but very abundant infection on Amelanchier, giving pycnia May I8, and aecia October I.

Another collection on the same host was sent by Dr. Fromme four days later from Woods Hole, Mass., and sown May if on leaves of Amelanchier canadensis, giving pycnia June 5, and aecia October 27. The results are in accord with previous cultures. ${ }^{40}$

26. Coleosporium Vernoniae B. \& C.-A collection of Peridermium carneum on Pinus taeda, gathered at East Lake, Fla., by Mr. H. E. Stevens, was sown April 13 on Aster paniculatus, Solidago canadensis, Euthamia graminifolia, Laciniaria punctata, L. Langloisii (the plant obtained from Texas), and Vernonia fasciculata. A sparing infection was obtained on the Vernonia only, uredinia being first noticed May 8 .

A similar collection sent by the same collector from Gainesville, Fla., was sown May 8 on Solidago canadensis, Laciniaria Langloisii, Elephantopus carolinianus, Amsonia salicifolia, and Vernonia fasciculata. Although all the hosts used were possible hosts for such a Peridermium, yet infection only occurred on the Vernonia, showing uredinia May 25 in abundance.

Uredinia from the last culture was sown May i7 on another plant of Vernonia fasciculata, with abundant infection, showing uredinia May 26. Another sowing from the same source was made May 28 on Aster paniculatus and Laciniaria Langloisii, with no infection.

The results are in accord with previous cultures, ${ }^{41}$ and add but little to our knowledge of the numerous southern species of Coleosporium.

SUCCESSFUl CULTURES REPORTED NOW FOR THE FIRST TIME: The following species have never before been cultivated, in America or elsewhere, so far as the writer knows. Some of those included in the above list, such as Puccinia vulpinoidis, P. Dulichii, $P$. tosta, and Peridermium fusiforme, might with some propriety have been placed here, as not till after the cultures were made was their true status as species known.

40 Mycol, I: 240. 1909.

41 Mycol. 4: 29 and 57. I912. 


\section{Cultures in I9I 3}

I. URomyces elegans (B. \& C.) Lagerh.-This autoecious rust, very common in the Southern States, is one of the group of species which produce no uredinia, so far as known, very few of which have been cultivated. Growing plants of Trifolium carolinianum bearing aecia were sent by Dr. F. A. Wolf from Auburn, Ala., and the aeciospores sown March 29 on plants free from the fungus. Teliospores began to appear about April 18 as the result.

This result does not disclose whether the species possesses both primary and secondary aecia, or whether pycnia ever occur. A culture with teliospores should be kept in view.

\section{Cultures IN I9I4}

2. Puccinia nodosa Ell. \& Hark.-While upon a visit to the Desert Botanical Laboratory at Tucson, Ariz., an exceptional opportunity was offered to study the life history of another autoecious species of rust, which like the one last mentioned, possesses no uredinia. A strong plant of Brodiaea pauciflora, growing near the door of the laboratory was moistened on February 26, sprinkled with aeciospores brought from some distance, and covered with a belljar. The temperature at the time was favorable for infection, the belljar being shielded from the direct rays of the sun. The experiment was left in charge of Dr. W. A. Cannon of the Laboratory staff, who kindly forwarded the leaves on March 18 , when the sori first opened. Only telia were produced.

As in the preceding case the possibility of both primary and secondary aecia occurring in the life cycle is not touched upon.

3. Puccinia splendens Vize.-Through the courtesy of the Desert Botanical Laboratory, Dr. Fromme and the writer were enabled to make an excursion on February 28 to the Santa Rita Mountains in the vicinity of Tucson, Ariz., where we secured teliosporic specimens of $P$. splendens on Hymenoclea monogyra. Through the kindness of Prof. J. J. Thornber of the University of Arizona we received after our return to Indiana a number of thrifty young plants of this host, which soon started into leaf in the green house. A sowing of teliospores was made April 7 , 
and another April 15, with no result. A third sowing on April 25 was better done, and gave rise to pycnia on the leaves May 6, and aecia May 20.

Aeciospores from this culture were sown May 26, which re-

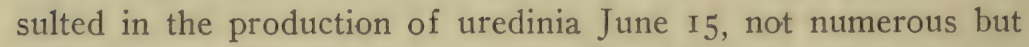
well formed. Uredinia continued to be produced until they were finally followed sparingly by telia July Io.

In every sowing an abundance of spores was used, which were applied to both leaves and stems. Tests of the spores showed unusually strong germination. Why the infection was so sparing and only on the leaves, while in the field the rust is chiefly on the stems, was not apparent. The cultures supply a knowledge of the pycnia and uredinia, neither of which were before known.

4. Puccinia minutissima Arth.-Viable material of this species on Carex filiformis was secured at much labor especially for this work by Mr. J. Dearness of London, Ontario, from the southeastern shore of Lake Huron. A collection made in December, I9II, was sown the following spring on seven hosts of as many genera without infection. Another collection of May, 1912, was similarly tested, and even more thoroughly, without success. A collection made in November, 19I3, was sown April 18, 1914, on Decodon verticillatus, with an abundant infection, showing pycnia April 27, and aecia May 7 .

The first suggestion for this connection was made by Prof. James B. Pollock of the University of Michigan, who wrote on August 3, 1909, as follows: "I found a rust on a patch of Carex filiformis, forming a half circle with a radius of about two rods around a specimen of Decodon verticillatus, some of whose leaves had an Aecidium on them. I send herewith specimens of both. No other Aecidium was found near the rusted sedge. The whole situation seems to me to indicate very closely the Decodon plant as a center of infection for the Carex rust."

The aecial stage of this rust is Aecidium Nesaeae Ger., but Puccinia Nesaeae Ellis \& Ev. does not belong here, having been founded on a telial collection with the host erroneously deterrnined. The error was detected by Prof. E. W. D. Holway.

5. Gymnosporangium Ellisil (Berk.) Farl--Material on Chamaecyparis thyoides was sent by Dr. Fromme from Lakehurst 


\section{Arthur: Cultures of Urednene 24687}

N. J., and sown May 6 on Myrica cerifera, giving rise to pyenia May 15 , and aecia June 6 . This most interesting result was in accord with field observations made by Dr. Fromme, who has recorded the steps which led to the inference of relationship, and has also discussed the results, in a paper ${ }^{42}$ anticipating this report.

The aecia of this species are of the aecidioid form, and not roestelioid, as in the majority of the species of the genus. Moreover, the host belongs to a family more divergent from the Malaceae, which bears most of the Gymnosporangial aecia, than heretofore supposed to be possible. The telial stage was once made the basis of a separate genus, Hamaspora, on account of the slender, more than two-celled teliospores. Completing a knowledge of the life history of a species with so many outlying characters is an especially notable achievement.

\section{SUMMARY}

The following is a complete list of the successful cultures made during the years 1912, 1913, and 1914. It is divided into two series, species that have previously been grown in cultures and reported by the writer or other investigators, and species whose culture is now reported for the first time.

\section{A. Species Previously Reported}

I, (8) and 14. Puccinia Grossulariae (Schum.) Lagerh. ( $P$. albiperidia Arth., $P$. quadriporula Arth.)-Teliospores from Carex arctata Boott, C. crinita Lam., C. pubescens Muhl., and C. tenuis Rudge, sown on Ribes Cynosbati L.

2, I5 and 19. Puccinia extensicola Plowr. ( $P$. CaricisAsteris Arth., P. Caricis-Solidaginis Arth., P. vulpinoidis D. \& H., P. Dulichii Syd.).-Teliospores from Carex retrorsa Schw., sown on Aster paniculatus Lam.; from Carex scoparia Schk., sown on A. paniculatus Lam. and Euthamia graminifolia (L.) Nutt.; from Carex vulpinoidea Michx., sown on Solidago canadensis L., S. glaberrima Martens, S. rugosa Mill. and S. mollis Barth.; from Dulichium arundinaceum (L.) Britt., sown on Solidago canadensis L.

42 Fromme, D. A. A new Gymnosporangial connection. Mycol. 6: 226230. 1914 . 
3. Puccinia angustata Peck.-Teliospores from Scirpus atrovirens Muhl., sown on Lycopus americanus Muhl.

4. Puccinia Ellisiana Thüm.-Teliospores from Andropogon sp., sown on Viola cucullata Ait. and $V$. Nuttallii Pursh.

5. Puccinia Stipae Arth.-Teliospores from Stipa comata Trin. \& Rupr., sown on Gutierresia Sarothrae (Pursh) B. \& R., and Senecio spartioides T. \& G.

6 and 21. Puccinia Agropyri E. \& E.-Teliospores from Elymus canadensis L., sown on Clematis ligusticifolia Nutt., and Anemone cylindrica A. Gray; from Elymus virginicus L., sown on Clematis Drummondii T. \& G.; and from Agropyron Smithii Rydb., sown on Clematis ligusticifolia Nutt.

7. Puccinia monorca (Peck) Arth.-Teliospores from Trisetum subspicatum (L.) Beauv., sown on Arabis sp., and aeciospores from Arabis sp., sown on Koeleria cristata (L.) Pers.

20. Puccinia Mumleniergine A. \& H. (P. tosta Arth.).Teliospores from Sporobolus asperifolius (Nees \& Meyen) Thurb. sown on Spaeralcea incana Torr. and S. lobata Wooton.

8 and 22. Uromyces PERIGYNIUS Halst.-Teliospores from Carex intumescens Rudge, sown on Aster paniculatus Lam., and Solidago canadensis L.; from Carex tribuloides Wahl., sown on Aster Tweedyi Rydb.

9. Uromyces Junci (Desm.) Tul.-Teliospores from Juncus balticus Willd., sown on Ambrosia psilostachya DC., A. trifida L., and Carduus Flodmanni Rydb.

Io. Uromyces acuminatus Arth.-Teliospores on Spartina Michauxiana A. S. Hitch., sown on Collomia linearis Nutt.

23. Uromyces Scirpi (Cast.) Burr.-Teliospores from Scirpus fuviatilis (Torr.) A. Gray, sown on Sium cicutaefolium Schrank.

i i. Gymnosporangium Nelsoni Arth. (G. durum Kern).Teliospores from Juniperus scopulorum Sarg., sown on Amelanchier canadensis (L.) Medic.

12. Gymnosporangium Betheli Kern.-Teliospores from Juniperus scopulorum Sarg., sown on Crataegus Pringlei Sarg.

i3. Gymnosporangium gracilens (Peck) Kern \& Bethel.Teliospores from Juniperus utahensis (Engelm.) Lemmon, sown on Philadelphus coronarius L. and P. Keteleerii Carr.

i6. Gymnosporangium clavariaeforme (Jacq.) DC.-Telio- 
spores from Juniperus sibirica Burgsd., sown on Crataegus cerromus A. Nels.

24. Gymnosporangium nidus-Avis Thax-Teliospores from Juniperus virginiana L., sown on Amelanchier vulgaris Moench. 25. Gymnosporangium Botryapites (Schw.) Kern.-Teliospores from Chamaecyparis thyoides (L.) B. S. P., sown on Amelanchier canadensis (L.) Medic.

I7. Cronartium Quercus (Brond.) Schröt. (Peridermium fusiforme Arth. \& Kern).-Aeciospores from Pinus taeda L., sown on Quercus rubra L., and.Q. Phellos L.

i8 and 26. Coleosporium Vernoniae B. \& C.-Aeciospores from Pinus taeda L. and P. palustris Mill., sown on Vernonia fasciculata Michx.; urediniospores from Vernonia fasciculata Michx., sown on same host.

\section{B. Species Reported Now for the First Time}

I. URomyces elegans (B. \& C.) Lagerh.-Aeciospores from Trifolium carolinianum Michx., sown on same host, producing telia.

2. Puccinia nodosa E11. \& Hark.-Aeciospores from Brodiaea pauciflora (Torr.) Standley, sown on same host, producing telia.

3. Puccinia splendens Vize.-Teliospores from Hymenoclea monogyra T. \& G., sown on same host, producing pycnia and aecia; aeciospores sown on same host, producing uredinia and telia.

4. Puccinia minutissima Arth. (Aecidium Nesaeae Ger.)Teliospores from Carex filiformis L., sown on Decodon verticillatus (L.) El1.

5. Gymnosporangium Ellisir (Berk.) Farl.-Teliospores on Chamaecyparis thyoides (L.) B.S.P., sown on Myrica cerifera L.

Purdue University,

LAFAYETTE, INDIANA. 



\section{CULTURES OF UREDINEAE IN I9I $5^{1}$}

\section{J. C. Arthur}

The present article is the fourteenth of a series of reports ${ }^{2}$ by the writer upon the culture of plant rusts, beginning in 1899 and completing seventeen consecutive years. With this report it is proposed to bring the series to a close. Hereafter the record of such cultures as may be undertaken will be made in whatever connection may be found advantageous. To render the work brought together in the present series more readily. accessible, and to make clear the changing point of view dominating the work, it is proposed to prepare an index and a brief historical statement, to be issued in the early future.

During the year 1915, little traveling was undertaken for the purpose of securing culture material and information. Two trips were made by the writer, the first one in April, the second in June, the first one in company with Mr. H. E. Ford, in order once more to explore the Kankakee marshes, in the northern part of Indiana, especially to gather information about Puccinia Seymouriana on Spartina. The rust was found in the greatest profusion, and specimens were taken from different parts of the region. Only one of these specimens showed viability, without much strength, and no infection was obtained from it. It is difficult to surmise what could cause such low viability, especially as the winter was mild and favorable to vegetation.

Correspondents in various parts of the country, as in previous ears, have sent material for cultures, of both the rusts and the living host plants. A number of correspondents took extra trouble to respond to requests for particular species, and to such

1 Presented before the Botanical Society of America at the Columbus meeting, December 30, 1915.

2 See Bot. Gaz. 29:268-276; 35:10-23; Jour. Myc. 8: $51-56 ; 10: 8-21$; II: $50-67 ; 12: 11-27 ; 13: 189-205 ; 14: 7-26 ;$ Mycol. 1:225-256;2:213-240; $4: 7-33,49-65 ; 7: 61-89$. 
rspecially not only the writer feels much indebted but the scientific public is placed under obligation. Among those who contributed in more or less degree to the studies of the present year the following are especially entitled to mention: Messrs. F. McAllister, I. M. Lewis and B. C. Tharp, Austin, Texas; W. A. Archer, Mesilla Park, N. Mex.; J. M. Bates, Red Cloud, Neb.; E. Bartholomew, Stockton, Kans.; E. Bethel, Denver, Colo.; J. F. Brenckle, Kulm, N. Dak.; H. L. Bolley, Fargo, N. Dak.; J. J. Davis, Madison, Wis.; A. O. Garrett, Salt Lake City, Utah; H. D. House, Albany, N. Y.; H. S. Jackson, Corvallis, Ore.; C. H. Kauffman and E. B. Mains, Ann Arbor, Mich.; Roy Latham, Orient, N. Y.; W. H. Long, Albuquerque, N. Mex.; C. R. Orton, State College, $\mathrm{Pa} ; \mathrm{J}$. L. Weimer and H. H. Whetzel, Ithaca, N. Y.

To indicate the extent of the work in making the cultures here reported the following statistics may be given. There were available I 8 collections with resting spores, and I 8 with active spores, i. e., taken from growing plants. Over 240 tests were made in a hanging drop to determine the germinating condition of the spores. Only 48 collections of resting teliospores could be brought to germination, from which IIo sowings were made, and 16 infections secured. From the 18 collections of fresh spores 34 sowings were made, and 3 infections obtained No extra assistant was employed for the work, as has been customary in preceding years, but it was carried forward by the regular staff of the laboratory, the larger share falling to $\mathrm{Mr}$. H. C. Travelbee.

Negative Results.-A number of collections giving good germination of spores produced negative results when sown upon hosts which are presumably aecial hosts for the species, but possibly not adapted to the racial material in hand. A few collections of species, for which no definite suggestions were available, were sown upon the seemingly most likely aecial host. In both cases the lack of positive results appears worth recording.

I. Puccinia amphigena Diet., on Calamovilfa longifolia (Hook.) Hack., collected by Mr. E. Bethel at Colorado Springs, Colo., Oct. I8, I9r4, and sent immediately to Lafayette, Ind., 


\section{1}

Arthur: Cultures of Uredineae in I 15 S 127

was sown March 3r, on Smilax hispida; another collection from the same locality, made May I6, I9I5, was sown on another plant of the same host May 24, both without infection. The leaves of the two collections sent by Mr. Bethel were thickly covered with the prominent, blackish telia. The teliospores germinated well, especially so in the October collection. Mr. Bethel stated on the label of the latter specimen that although the rust was very abundant, there were no Smilax plants in the region. In sending the May collection he stated on the label that the aecial stage occurred on Leucocrinum, but desired to have the material tested on Smilax. In the accompanying letter of same date he says: "I am inclosing Puccinia amphigena on Calamovilfa longifolia, which I wish you would sow on Smilax, which I believe you give as host in the east. I have fine young plants of native Smilax, but have failed to inoculate them. With us this does not normally belong to Smilax, and may be another race. It belongs to Leucocrinum, on which it is epidemic everywhere this year." This species of rust was first cultured on Smilax in 1902, from telial material gathered at Callaway, Neb., and in the year following from material gathered at the type locality in Chicago, Ill. It has been cultured altogether six times, ${ }^{3}$ the westernmost locality for telial material being central Nebraska, on the plains, some two hundred miles from the foothills of the Rocky Mountains, where this season's material was obtained.

2. Puccinia emaculata Schw., on Panicum capillare L., collected at Lafayette, Ind., was sown, May 21, on Euphorbia corollata, having shown strong germination, but without results. The reasons for this attempt, with citation of other trials, are given in the previous report of cultures. ${ }^{4}$

3. Puccinia simillima Arth., on Phragmites communis Trin., collected by Dr. J. F. Brenckle, at Wiedmer's Lake, N. Dak., on April II, I9I5, was sown May I4, on Anemone cylindrica and Ranunculus acris, without infection. It was sown again June 18 on two plants of Ranunculus sceleratus, but with no infection.

3 See Bot. Gaz. 35:20. 1903; Jour. Myc. 10:11. 1904; 12: 16.1906 ; 14: 15. 1908; Mycol. 2:225. 1910; and 4: 18. 1912.

4 Mycol. $7: 65$. 1915 . 
This species was successfully cultured in 1902 and again in 1907 on Anemone canadensis. ${ }^{5} \quad$ A recent monographic study of American grass rusts confirms the early opinion ${ }^{6}$ that this species is similar, morphologically and in host requirements, to P. Magnusiana of Europe, which has been found to have aecia on $R a$ nunculus acris and $R$. bulbosus. Aecia were collected by Dr. Brenckle on $R$. sceleratus, May 30, 1908, near Kulm, N. Dak., which are structurally similar to the American form on Anemone, as well as to the European form on Ranunculus. An appeal to Dr. Brenckle for living plants of $R$. sceleratus was met with some difficulty upon his part, but successfully, and telial material also was sent from a locality not far away from the place where aecia on $R$. sceleratus had been obtained, but nothing definite has been proven. It still seems probable, however, that $P$. simillima is but a racial variant of $P$. Magnusiana, and that a race may finally be found in America with aecia on Ranunculus, although the common form is on Anemone.

4. Puccinia Rinamini (Pers.) Wettst., on Nothoholcus lanatus (L.) Nash (Holcus lanatus L.), sent by Prof. H. S. Jackson from Corvallis, Ore., was sown April 2 on Rhamnus cathartica and Lepargyraea canadensis, with no infection. Another collection of the rust on Scolochloa festucacea (Willd.) Link, sent by Dr. J. F. Brenckle from Kulm, N. Dak., was sown May 8 on Lepargyraea canadensis and Eleagnus argentea, and again May 21 on Rhamnus cathartica, all without infection. Aecia are known to be common about Corvallis on Rhamnus Purshiana, but not found on Lepergyraca, the host being absent from the region, while at Kulm aecia are common on Eleagnus, but whether the latter belong to a race of $P$. Rhamni, or to an independent species is not yet known.

5. Puccinia Agropyri E. \& Ev., on Hordeum jubatum L., sent by Dr. Brenckle from Wiedmer's Lake, N. Dak., was sown May 13 on Anemone cylindrica, Clematis ligusticifolia, and Aquilegia sp., without infection. Recent monographic study of the

5 Bot. Gaz. $35: 20.1903$; and Jour. Myc, 14: 15. 1908.

6 Arthur, The Uredineae occurring upon Phragmites, Spartina and Arundinaria in America. Bot. Gaz. 34: 18. 1902. 


\section{3 \\ Arthur: Cultures of Uredineae in Igs 5 ; 129}

grass rusts has shown the probability that this form, usually reported under the name $P$. rubigo-zera, is a part of the comprehensive species, $P$. Agropyri, with aecia on different Ranunculaceous hosts, forming well defined races. ${ }^{7}$

6. Uromyces Scirpi (Cast.) Burr., on Scirpus fuviatilis (Torr.) A. Gray, sent by Dr. J. F. Brenckle from Kalmbach Lake, Lamoure Co., N. Dak., was sown March 26 on Sium cicutaefolium and $H_{y}$ drocotyle australe, and again May 19 on other plants of the same two species, without infection. The species apparently is made up of races, a study of which was the aim in this attempt at cultures. ${ }^{8}$

7. Uromyces Archerianus Arth. \& Fromme, on Chloris elegans H. B. K., collected Nov. 12, 1914, and again Feb. 7, 1915, by Mr. W. A. Archer, at Mesilla Park, N. Mex., was sown April 15, each collection on a different plant of Chenopodium album, with no infection. This new species of rust was discovered in abundance upon the campus of the New Mexico Agricultural College, with no distinctive aecia in the vicinity. Because of its morphological resemblance to Uromyces Peckianus, it was tried upon Chenopodium.

8. Aecidium Iridis Ger., on Iris versicolor L., from the Renwick Swamp, Ithaca, N. Y., was sent by Mr. J. L. Weimer in abundance and in excellent condition, and on July I, the third day after collection, was sown on a large and especially thrifty plant of the same species of Iris, but gave no infection. A test of the spores showed that seventy-five to ninety per cent. were in germinating condition. Field observations have given little or no grounds for considering this rust autoecious, and the present trial further emphasizes this view. However, up to the present time no one has detected a probable alternate host.

Successful cultures Supplementing Previous work.-The facts derived by growing the following species of rusts supplement in a variety of ways the facts obtained from previous cultures in this series from cultures recorded by other American

7 For previous attempts at cultures see Mycol. 2:219. 1910.

8 For previous culture work see Jour. Myc. 13:199. 1907; 14:17. 1908; Mycol, I: 237. I909; and 7:83. 1915. 
or European investigators. The extension of aecial hosts for Puccinia Seymouriana to two families not closely related to the one previously known is especially important, and the behavior of rye rust upon Anchusa appears to have significance.

I. Puccinia extensicola Plowr. (P. Dulichii Syd.).-A collection of this rust on Dulichium arundinaceum, made at DeMotte, in the Kankakee marshes of northern Indiana, by Mr. H. E. Ford and the writer on April 6, I9I5, was sown April 19, on two plants of Aster paniculatus, one brought from the spot where the collection was made, and the prevailing plant at the place, and also on a plant of Solidago canadensis. Abundant pycnia began to show on the Solidago April 26, and aecia May 9, while the two Aster plants were unaffected. The result agrees with the facts obtained in $1914^{9}$ with similar material from Florida.

2. Puccinia Grossulariae (Schum.) Lagerh.-Material collected by Mr. Roy Latham at Greenport, Long Island, N. Y., on Carex tenuis, was sown March 25 on Ribes floridum with no infection, and March 31 on R. Cynosbati, giving rise to pycnia April I3, and aecia May 4. The aeciospores thus produced were sown May 4 on Carex pubescens, with no infection. Another collection made by C. H. Kauffman and E. B. Mains at Lake Placid, N. Y., on Carex arctata, was sown March 15, on Ribes Cynosbati, giving a few pycnia March 26, but failing to develop further on account of injury to host. The same material was sown again March 26 on another plant of the same sort, giving pycnia April 2, and aecia April 26, the growth being slow. Both the original telial collections gave many urediniospores, all of which appeared to have but one basal pore, and they may be considered pure representatives of Puccinia uniporula Orton. The aecia were not distinguishable from those grown in previous years from material showing equatorially three-pored urediniospores. It was hoped that aecia so grown might be carried back to the telial host, and the character of the resulting urediniospores ascertained, but although an attempt was made, it failed.

A collection' of aecia on Ribes longiflorum sent from Denver, Colo., by Mr. E. Bethel, was sown June 4, two days after collec-

9 Mycol. 7 : 81. 1915. 
tion, upon Carex durifolia, a species from which the aecia were supposed to have been derived, and also upon $C$. Jamesii, with no infection. ${ }^{10}$

3. Puccinia Eriophori Thüm.-Observations by Dr. H. D. House of the New York State Museum, made near Oneida, N. $Y$., in June of this year, led to the recognition of this species of rust in America and the discovery of the alternate stage. On June 27 Dr. House wrote that "of thousands of plants of Senccio in the marsh practically every one is affected by the Aecidium." He found that of the numerous marsh plants the one having a corresponding abundance of rust on the dead leaves from the preceding year was Eriophorum viridi-carinatum. At the same time he sent growing plants of both the Senecio and Eriophorum, the former with leaves well spotted with aecia. All the plants continued to flourish.

On June 30 a sowing of aeciospores from Senecio aurcus was made on the young leaves of Eriophorum viridi-carinatum. After twenty-four hours a test of the spores remaining on the leaves of the Eriophorum showed that from twenty to forty per cent. of them were germinating. Daily observation of the plant was not made, but on July I5 both uredinia and telia were found to be present. The rust on American species of Eriophorum is morphologically very similar to Puccinia angustata Peck on various species of Scirpus, and usually has been listed under that name. As $P$. angustata has its alternate stage on the labiate, Lycopus, the same had been supposed to be true of the rust on Eriophorum, and thus to differ from the similar rust in Europe.

Tranzschel11 has reported the infection in 1907 of Ligularia sibirica (Senecio cacaliaefolius) and Senecio paluster (Cineraria palustris) from teliospores on Eriophorum angustifolium, and has listed the European stations for the rust, showing that it is quite rare. In America it has been taken on Eriophorum angustifolium Roth, at Decorah, Iowa, June 29, I884, E. W. D. Holway, Kennedy, Neb., July 20, I892, J. M. Bates, Newfane, Vt., Oct. I6,

10 For previous cultures see Jour. Mycol. 12: 58 . 1905; 12:14. 1906; 13: 196. 1907; 14:13. 1908; Mycol. 4:13. 1912; and 7:66, 78. 1915.

11 Beiträge zur Biologie der Uredineen, III. 
I892, A. J. Grout; on E. polystachyon L., Mt. Hood, Ore., at 5,000 feet altitude, July 23, I9I5, H. S. Jaikson; on E. tenellum Nutt., at Isle au Haute, Me., Sept. II, I899, J. C. Arthur; on E. virginicum L., at Avilla, Ind., August, 1884, W. B. VanGorder, Granville, Mass., August I889, A. B. Seymour (Seym. \& Earle, Econ. Fungi 54), Isle au Haute, Me., Sept. 6, I899, J. C. Arthur, Central Village, Conn., Aug. 20, 1900, John L. Sheldon, Jackson, Ind., July 28, I905, C. C. Deam, Elm Lake, Wis., Sept. I2, I907, C. L. Shear, Winona Lake, Ind., Aug. 26, I914, G. N. Hoffer; on E. viridi-carinatum (Engelm.) Fernald, at Avilla, Ind., August, 1884, W. B. VanGorder, Oneida, N. Y., June 27, I9I5, H. D. House; on Senecio aureus L., at Buffalo, N. Y., without date, G. $W$. Clinton, Decorah, Iowa, June, I883, E.W. D. Holway, Ann Arbor, Mich., June 8, I898, C. H. Kauffman, Mt. Chocorua, N. H., July 3, г906, W. G. Farlow, Radisson, Wis., July 6, ı906, J. J. Davis, Merrimac, Wis., June I9, I912, Davis \& Arthur, Oneida, N. Y., June 27 , I9I5, H. D. House; on S. ductoris Piper, Mt. Hood, Ore., at 5,000 feet altitude, July 23, I9I 5, H. S. Jackson. It is evident that the rust is widespread in America, especially northward, but not particularly abundant, and the aecia have been collected over nearly the same territory as have the telia.

The morphological differences between $P$. angustata and $P$. Eriophori are very considerable in the aecia, and while less marked in the uredinia and telia are yet noticeable. The urediniospores of $P$. Eriophori are more globoid, while the teliospores are somewhat shorter (35-60 $\mu$ long, against $42-67 \mu$ in $P$. angustata) and the apex thinner ( $4-10 \mu$, against $7-16 \mu$ in the other) with more tendency to acuteness.

4. Puccinia Agropyri E. \& Ev. (P. alternans Arth.)-A collection on Festuca Thurberi Vasey, sent from Lake Eldora, Colo., by Mr. E. Bethel, was sown May I3, on Anemone cylindrica, Aquilegia canadensis, Clematis ligusticifolia, and Thalictrum dioicum. Infection was obtained on the last named host only, which began to show pycnia May 23, and aecia May 30. In sending this material Mr. Bethel wrote that he thought it had been derived in the field from aecia on Thalictrum Fendleri, which the culture confirms as highly probable. The first collection of this 
Arthur: Cultures of Uredineae in I9 52573

kind sent the writer by Mr. Bethel was dated Sept. 17, I910, and was intended for cultures on Thalictrum. This could not be made to germinate when time for culture work arrived, nor could a half dozen other collections sent subsequently at various dates. With a specimen dated April 5, 1912, Mr. Bethel states that he has "proven by most positive field cultures" that it goes to Thalictrum Fendleri. Again in May, 1915, Mr. Bethel sent fine materia! [rom his garden, showing the telia that had been brought there anri the aecia on Thalictrum derived therefrom. The reasons for listing the Thalictrum form under P. Agropyri were stated in the last report. ${ }^{12}$ The aecia are especially large and prominent in this particular race on Festuca, as shown by a number of collections sent from the same locality.

5. Puccinia Asperifolir (Pers.) Wettst.-Two plants of $A n$ chusa officinalis $\mathrm{L}$. were given ample space in the experimental garden of the Indiana Experiment Station and attained a fine development, each plant measuring five or six feet across. On July 2 , the weather being especially damp with occasional light showers, stems of rye, heavily infested with rust, were laid upon the two plants in the garden, doubtless a hundred or more stems to each plant. The plants were not covered in any manner. The date of the appearance of the first pycnia was not recorded, but on July I3, the plants were conspicuously dotted with yellow spots bearing groups of pycnia. About a week later careful search brought to light two groups of aecia. Although the vigor of the plants and the condition of the weather seemed favorable, and the great numbers of yellow spots with their groups of pycnia continued to show, yet no further development of the rust took place. ${ }^{13}$

The reason why the infection should have started out with such marked vigor and yet failed to mature aecia is not at all apparent. The weather for the whole period was favorable for aecial growth. It is possible, and yet scarcely probable, that the explanation lies in the lessened vigor for the American rye rust, which is propagated by repeating spores alone, the aecial hosts being practically wanting in America.

12 Mycol. 7:74. 1915.

13 For a previous culture of similar character sce Mycol. I: 236. 1909. 


\section{8}

6. Puccinia Seymouriana Arth. (Aecidium obesum Arth.).This rust on Spartina at the time it was described in 1902 was predicted upon morphological and geographical grounds to have its alternate form upon the Rubiaceous genus Cephalanthus, ${ }^{14}$ the prediction being established by cultures in 1905, and confirmed in subsequent seasons. ${ }^{15}$ It was not until June, I9I3, that additional suggestions came to light, when Rev. J. M. Bates wrote that his observations in the field led him to believe that in Nebraska this rust on Spartina was connected with an Aecidium on Apocynum hypericifolium. He sent a specimen of the aecia, which proved to be Aecidium obesum Arth. This collection was distributed as $4 I 03$ of Barth. Fungi Columbiani, and I3OI of Barth. N. Amer. Ured. Later in the year a careful microscopic comparison of these aecia with those on Cephalanthus established their essential similarity. Owing to adverse seasonal conditions Mr. Bates was unable to supply culture material for the I9I4 cultures, but on May 8, 1915, he sent telial material on Spartina Michauxiana from Eight Mile Creek, near Red Cloud, Neb. It was sown May 12, on Apocynum cannabinum, Amsonia salicifolia, Asclepias syriaca, and Cephalanthus occidentalis, producing a scanty infection only on Apocynum, pycnia showing June Io, but without developing aecia.

A specimen of aecia on Asclepias pulchra, collected by Mr. Roy Latham, of Orient, N. Y., June 29, I9I4, was reported to the collector upon cursory examination only, as aecia of Puccinia Jamesiana, that being the only species at that time known to have aecia with a limited mycelium on Asclepias, and it was suggested that he search for telial material on Bouteloua. Not long afterward he wrote that Bouteloua was not known upon Long Island, and that among the infected milkweeds, which occur on "a patch about 100 feet in length by 25 in width, many plants being actually covered from ground up, stem, leaves, and all," the only grass or sedge bearing rust was Spartina cynosuroides, of which he sent leaves covered thickly with telia remaining over from the preceding year, and young leaves of the season with uredinia. The Spartina rust

14 Bot. Gaz. 34: 13.1902.

15 Jour. Myc. 12:24. I906; Mycol, I: 236. 1909; 4 : I9. I910. 


\section{9 \\ Arthur: Cultures of UREdineae in 1915}

proved to be $P$. Seymouriana, and the aecia on Asclepias resembled those belonging to that species. Mr. Latham kindly sent viable material for cultures, collected at the same spot June 2, 1915, which was sown June Io on plants of the four hosts used in the previous culture. Only Asclepias syriaca became infected, showing an abundance of pycnia June $I 7$ and great numbers of aecia June 23.

It may fairly be concluded that this species of rust is one composed of well-marked races in accordance with the aecial hosts. Besides the three races here indicated, another doubtless occurs in connection with Amsonia, the characteristic aecia having been found on this host from Missouri.

7. Puccinia subnitens Diet.-A collection of this rust on Distichlis spicata, very common in alkaline regions, was sent by Prof. H. S. Jackson from LaGrand, Ore., and sown April 15, on Chenopodium album. Pycnia began to show April 25, and aecia May 8, chiefly on the petioles of the leaves. ${ }^{16}$ Telial material has now been cultured from the states of Nebraska, Colorado, Telaware, Nevada, and Oregon, extending from the Atlantic to the Pacific coasts.

8. Puccinia Windsoriae Schw.-Much attention has been given to finding the telial host for the aecia on Dirca palustris, beginning with the illusory success of 1903 and continuing to the present time. ${ }^{17}$ Many telial collections have been used, secured from widely separated localities, and representing many species of rusts. During the last year a search through the herbarium for aecia on other hosts, having similar microscopic characters, led to the possibility that it might be a racial part of the common Puccinia Windsoriae. To test this hypothesis telial material was secured near Lafayette, on Tridens flavus, from the vicinity of Dirca bushes, annually showing the lemon-yellow spots carrying the aecia. Sowings were made May 3, on Dirca palustris, May

10 For previous cultures see Bot. Gaz. 35: 19. 1903; Jour. Myc. II : 54. 1905; 12:16. 1906; 13:197. 1907; 14: 15. 1908; Mycol. 1:234. 1909; 2:225. 1910 ; and $4: 18,54,1912$.

17 For previous attempts see Jour. Myc. 10: $29.1904 ; 11: 56.1905 ; 13$ : 191, 192, 196. 1907; 14:12. 1908. Mycol. 1:231. 1909;2:219, 227. 1910; $4: 9,10,11,12.1912 ; 7: 64,65.1914$. 
22, on Dirca and Ptelea trifoliata, May 24, on Ptelea. Only on Ptelea was infection secured, abundant pycnia showing from both sowings June 2 , and aecia June $7 .^{18}$

SUCCESSFUl CUltURES REPORTED NOW FOR THE FIRST TIME.The following species have never before been cultivated in America or elsewhere, so far as the writer knows.

I. Puccinia tumidipes Peck.-Excellent telial material of this species on Lycium pallidum, was sent by Mr. W. A. Archer, collected in the Organ Mountains, N. Mex., on Oct. 9, 19I4. As it was found the teliospores would germinate, it was sown Dec. I, I9I4, on plants of Lycium vulgare, giving a few pycnia only by Dec. I8, with no further development, possibly owing to the poor condition of the host plant. It was sown again on another plant of the same sort Dec. 12, 1914, giving rise to a few groups of pycnia by Dec. 21, and a single uredineal sorus Jan. I6, I9I 5 .

Although the growth of the fungus was not vigorous, and did not continue to the final stage, yet it seems safe to conclude that the rust is autoecious, and without cupulate aecia. It clearly belongs in the genus Bullaria, where it becomes B. tumidipes (Peck) comb. nov.

2. Puccinia Distichlidis Ellis \& Ev.-This rust in the first place was sent to Mr. Ellis in I891 by F. D. Kelsey of Helena, Mont., and labeled as on "Distichlis maritima," but afterward was shown by the writer ${ }^{19}$ to be on Spartina gracilis. On account of this erroneous determination of the host plant, the rust was renamed $P$. Kelseji by Sydow. ${ }^{20}$ In a study of "Correlation between certain species of Puccinia and Uromyces" Orton ${ }^{21}$ came to the conclusion from a comparison of the morphological characters and geographical distribution of Uromyces Spartinae and the rust in hand, that it was "extremely probable that its aecial host is some member of the primrose family, perhaps Steironema," this being one of the aecial hosts for the Uromyces. It has been

18 For previous successful cultures see Bot. Gaz. 29: 273. 1900; 35: 16. I903; Jour. Myc. II : 56. I905.

19 Bull. Lab. Nat. Hist. Univ. Iowa $5: 324.1902$.

20 Sydow, Monog. Ured. I: 806. I904.

21 Mycol. 4:202. 1912. 


\section{1}

Arthur: Cultures of Uredineae in 1915, 2 : 137

difficult to locate this rust in localities from which culture material could be secured. Dr. Brenckle sent material from Kulm, N. Dak., from which cultures were attempted in 1909 and $19 \mathrm{IO}^{22}$ upon a score of different hosts, but not including Steironema. Again material on S. Michauxiana was obtained from Dr. Brenckle, collected April 8, I915, at Kulm, N. Dak., and also from Rev. J. M. Bates, collected April 20, 1915, at Loup City, Neb.

The North Dakota material was sown May 8, on Steironcma ciliatum, and pycnia began to show May I6, followed by an abundance of aecia May 22. The Nebraska material was sown May 8, on Steironema ciliatum and Polemonium reptans. The Polemonium plant remained uninfected, but many pycnia began to show on the Steironema May I4, followed by a great abundance of aecia May 20. Although these cultures were exceedingly vigorous and in so far seemed beyond question, yet there exists a possible small source of error. The correlated Uromyces is a common rust, and occasionally grows upon the same leaves with the Puccinia. In the Nebraska material no admixture could be found, but there were sori of Uromyces on the North Dakota material. Care was exercised, however, to avoid all sori with onecelled spores in making the cultures, and as the two forms were mostly on separate leaves, there is little reason to doubt that the cultures were pure. Correctness of the general conclusion was obtained from a wholly independent source, however, when Dr. Brenckle sent a collection of aecia on Steironema ciliatum, made by Prof. O. A. Stevens near Fargo, N. Dak., May 23, I915. On June 5 Dr. Brenckle accompanied Prof. Stevens to the spot where the collection was made, to institute a search for Spartina, as Prof. Stevens had reported that the grass did not grow within miles of the place. Dr. Brenckle writes, June 16 , that he "found a small isolated bunch of Spartina in the midst of the infected spot; the rust on the Spartina was Puccinia!'” The collection of aecia has been issued as Fungi Dakotenses 316, under the name of Puccinia Distichlidis. This is the only field collection of aecia positively known to belong to the Puccinia form.

3. Peccinia montanensis Ellis.-There has been much con22 Mycol. 2 : 219. 1910; 4:11. 1912. 
fusion in the application of this name. Not until within the present year has it been possible to secure a clearly defined set of characters with which to delimit the species, especially to distinguish it from Puccinia Agropyri E. \& E., with which it often grows, and which it resembles in gross appearance. It is now found to be separable from $P$. Agropyri, by the slightly thinnerwalled urediniospores, having more pores ( 8 to ro, instead of 6 to 8 in $P$. Agropyri), sometimes accompanied by paraphyses, but more especially by the far broader teliospores (I 8 to $34 \mu$ wide, against $I 3-24 \mu$ in the other species), which generally approximate an oblong form with convex sides, in contrast with terete spores usually with straight sides in P. Agropyri.

The rust in question has often been labeled P. apocrypta E. \& T. The type of P. apocrypta was collected at Canon City, Colo., August 21, 1887, and was recorded as on Asprella Hystrix. The type collection is now in the herbarium of the Missouri Botanical Garden, and has been carefully examined by a number of students of the grasses. The specimen is scanty, and consists of leaves only. It can not be the species of grass named, which does not occur within the region. It seems most likely to be some species of Sitanion possibly S. elymoides, a common species of the region much resembling Hystrix. The rust is certainly P. Agropyri, although the teliospores are rather broader than usual. The type material of $P$. montanensis, which is in the herbarium of the New York Botanical Garden, has been examined and bears out the published statement that it is on Elymus condensatus. It was collected at Helena, Mont., July 25, I89I, by F. D. Kelsey.

The fortunate observation which led to the elucidation of this species was made by Mr. A. O. Garrett, of Salt Lake City, Utah, who wrote on May 23, I9I5: "I am sending by this mail some leaves of Hydrophyllum [capitatum] heavily infected with Aecidium Hydrophylli. I think this rust has the alternate stage on Agropyron. I always find the Agropyron plant plentiful, and it is affected by the rust, wherever the Hydrophyllums grow." The aecia on Hydrophyllum sent by Mr. Garrett came in good condition, and were sown May 28, on Agropyron tenerum and Elymus virginicus. Uredinia began to show in abundance June 7 , on the 


\section{Arthur: Cultures of Urenineae in 19993}

Agropyron, followed by telia June II. On the Ely'mus only a few uredinia developed, not observed until June 23. A study of the uredinia and telia on the Agropyron disclosed the characters of Puccinia montanensis. Field observations by Dr. Brenckle of North Dakota, Mr. Garrett of Utah, and Mr. Bethel of Colorado, independently reported, associated aecia on Lithospermum, Onosmodium, and Phacelia, with Agropyron and Elymus rust, but material sent to establish the connection by cultures failed to yield results. Subsequent herbarium studies leave little chance for doubt that Puccinia Agropyri has its alternate form on $\mathrm{Ra}$ nunculaceous hosts, while $P$. montanensis has its alternate form on Hydrophyllaceous and Borraginaceous hosts.

Two former attempts at culture of $P$. montanensis ${ }^{23}$ are shown by a reexamination of the original material to have been made by using P. Agropyri, and not P. montanensis, as published.

4. Uromyces Horder Tracy.-Telial material on Hordeum pusillum Nutt., sent by F. McAllister and B. C. Tharp from Austin, Texas, was sown March I5, on Nothoscordium striatum and Ornithogalum umbellatum, and again March 30 on the latter host, with infection only on the Nothoscordium, showing pycnia March 30, and aecia April 6, both strongly developed.

When the report of culture experiments for the years I9I I to I9r3 by W. Tranzschel ${ }^{24}$ came to hand, the account of the successful growth of barley rust on Ornithogalum umbellatum suggested the renewal of a study of the correlated American species of Uromyces, $U$. Hordei Tracy. There is no morphological difference between the uredinia and telia of the latter species and those of Puccinia anomala Rostr. (P. simplex Eriks. \& Henn.), except that part, rarely all, of the teliospores of the Puccinia are two-celled. Ornithogalum umbellatum is the Star-of-Bethlehem of the florists, and has escaped from gardens and become a weed in the southern states as far northward as the Ohio river. Aecia on it have not been reported for America, but they are known on a near relative, Nothoscordium bivalve (L.) Britton (Ornithogalum biralve L.), from Texas. An appeal to Dr. McAl-

23 Jour. Myc. 14: Ix. I908; and Mycol. I: I1. 1912.

24 Mycol. Centr. 4: 70. 1914. 
lister and Mr. Tharp, of the University of Texas, made in November, I9I4, soon placed in my possession resting telia on Hordeum pusillum and dormant bulbs of the Nothoscordium, which were made to yield the above results.

In the meantime it was remembered that Mr. W. H. Long had reported this connection several years before. In a letter dated Feb. 28, 1904, he says: "I have successfully grown Uromyces Hordei urediniospores from sowings of aeciospores that I find on Nothoscordium striatum [N. bivalve]." Again on March 24, I9I0, Mr. Long wrote: "Since writing you last I have cross-inoculated teliospores on Nothoscordium striatum, and aeciospores from it upon Hordeum nodosum [error for H. pusillum], and got successful cultures in both instances." Mr. Long kindly sent material to illustrate his work and also material with which to verify his conclusions. Unfortunately it was not possible to bring about conditions for the cultures, and as Mr. Long's work was done in the open, and not verified by others, the results were omitted from the North American Flora when this species was reached..$^{25}$

In this connection it may be well to say that the statement in the North American Flora that the species occurs in California on Hordeum nodosum is erroneous. The species ranges from Nebraska to Mississippi and Texas, which also includes the range of the aecial host, although the aecia have only been taken in Texas.

\section{Summary}

The following is a complete list of the successful cultures made during the year 1915. It is divided into two series, species that have previously been grown in cultures and reported by the writer or other investigators, and species whose culture is now reported for the first time.

\section{A. Species Previously Reported}

I. Puccinia extensicola Plowr. (P. Dulichii Syd.).-Teliospores from Dulichium arundinaceum (L.) Britt., sown on Solidago canadensis $\mathrm{L}$.

$25 \mathrm{~N}$. Amer. Flora 7: 228. I912. 
Arthur: Cultures of Uredineae in I91 $26 \mathrm{i}_{141}$

2. Puccinia Grossulariae (Schum.) Lagerh. ( $P$. uniporula Orton).-Teliospores from Carex tenuis Rudge, and from $C$. arctata Boott, sown on Ribes Cynosbati L.

3. Puccinia Eriophori Thüm.-Aeciospores from Senecio aureus L., sown on Eriophorum viridi-carinatum (Engelm.) Fernald.

4. Puccinia Agropyri Ellis \& Ev. (P. alternans Arth.).Teliospores from Festuca Thurberi Vasey, sown on Thalictrum dioicum $\mathrm{L}$.

5. Puccinia Asperifolit (Pers.) Wettst.-Teliospores from Secale cereale L., sown on Anchusa officinalis L.

6. Puccinia Seymouriana Arth. (Aecidium obesum Arth.).Teliospores from Spartina Michauxiana Hitchc., sown on Apocynum cannabinum L., and from Spartina cynosuroides (L.) Roth, sown on Asclepias syriaca L.

7. Puccinia subnitens Diet.-Teliospores from Distichlis spicata (L.) Greene, sown on Chenopodium album L.

8. Puccinia Windsoriae Schw.-Teliospores from Tridens flavus (L.) Hitchc. (Tricuspis seslerioides Torr.), sown on Ptelea trifoliata L.

B. Species Reported Now for the First Time

I. Puccinia tumidipes Peck.-Teliospores from Lycium pallidum Miers, sown on $L$. vulgare Dunal, producing pycnia and uredinia.

2. Puccinia Disticinlidis Ellis \& Ev.-Teliospores from Spartina Michauxiana Hitchc., sown on Steironema ciliatum (L.) Raf.

3. Puccinia montanensis Ellis (Aecidium Hydrophylli Peck). -Aeciospores from Hydrophyllum capitatum Dougl., sown on Agropyron tenerum Vasey and Elymus virginicus L.

4. Uromyces Hordei Tracy.-Teliospores from Hordeum pusillum Nutt., sown on Nothoscordium bivalve (L.) Britton.

Purdue University,

LAFAYETTE, INDIANA. 



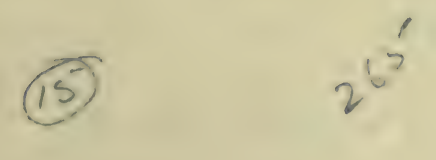

CULTURES OF UREDINEAE IN I9I6 AND I9I7 


\section{CULTURES OF UREDINEAE IN I9I6 AND I9I $7^{1}$}

J. C. Arthur

The present article is the fifteenth in a series of reports ${ }^{2}$ by the writer upon the culture of plant rusts, beginning in 1899 and completing nineteen consecutive years. The preparation of the index and summary to the series, as stated in the report for last year, has been delayed, but together with a general retrospect is expected to appear in a succeeding number of this journal. After this, if work of the present character is continued, it will be reported in some other form.

\section{Field Observations in igi6}

The writer, by the courtesy of the botanical department of the Indiana Agricultural Experiment Station now under the direction of Professor H. S. Jackson, was enabled to make important observations in the field during 1916, which have proved of the utmost value, not only in detecting the alternate form of certain heteroecious species, but in securing a more adequate conception of the different aspects and range of hosts of particular species when occurring under unlike conditions or in the midst of plant societies composed of different elements.

The first trip of the year was to State College, $\mathrm{Pa}$., in the last days of April, where Dr. F. D. Kern and his associates in the botanical department of the Pennsylvania State College gave every facility for a week's field work. Two excursions in the vicinity are especially worthy of mention, both taken under the personal direction of Professor C. R. Orton. An over-mountain road took us to Charter Oak, where the locality for the amphi-

1 Presented in part before the Botanical Society of America at the New York meeting, December 29, 1916.

2 See Bot. Gaz. 29: 268-276; 35 : 10-23; Jour. Myc. 8: $51-56$; 10: $8-21$; II : $50-67 ; 12: 11-27$; 13 : 189-205; 14: 7-26; Mycol. I: 225-256; 2: 213$240 ; 4: 7-33,49-65 ; 7: 61-89 ;$ and $8: 125-141$. 
sporic Carex rust, Puccinia microsora Körn., was searched for clues to the alternate host without much success. Adrrefsemile ride in another direction to Bear Meadow, an extensive mountain bog, gave opportunity to study the occurrence of $P$. uniporula, and some other difficult Carex forms.

On May I3 a western trip of a little over three weeks was begun. The first stop was a few days given to the study of the rust flora of the semi-arid plains between Grant and Ogallala in western Nebraska, where the second telial host for Puccinia universalis to be proven by cultures was found.

Next came a few days (May 18-22) at Laramie, Wyo., altitude of 7,500 feet, where the season was not sufficiently advanced for the best field work, but where through the courtesy of Professor Aven Nelson and the assistance of Mr. Edwin Payson an examination of the extensive and valuable Rocky Mountain Herbarium yielded many new hosts and localities for numerous western rusts.

Interesting observations were made (May 23-24) in the vicinity of Ft. Collins, Colo., where every attention was extended by members of the biological staff of the Agricultural College. Professor W. W. Robbins undertook to continue the observation of a number of clumps of Astragalus and Oxytropis as the season advanced. These plants were growing with masses of aeciabearing Euphorbia robusta intermixed. On October 24 Professor Robbins reported that no rust had appeared on any of the plants of Astragalus or Oxytropis under observation. From European studies it has seemed probable that the perennial aecia on upright Euphorbias and the Uromyces punctatus on Astragalus and allied hosts, both especially abundant in the Rocky Mountains, were alternating forms of the same rust, but so far neither repeated attempts at cultures nor field evidence have afforded any support to the assumption.

At Windsor, Colo., as the guest of Mr. Geo. E. Osterhout (May 25), a fine display of over-wintered Puccinia Distichlidis on Spartina was seen in the field with an abundant growth of Stieronema ciliatum nearby. Telial material from this locality subsequently gave successful cultures, and on June $12 \mathrm{Mr}$. Osterhout sent aecia on Stieronema, which he obtained from the spot 
visited. This is the second culture and the second aecial field collection so far secured.

At Denver the writer was joined by Professor H. S. Jackson. While here (May 26-3I ) we were under the guidance of Mr. Ellsworth Bethel, whose extensive knowledge of the flora of Coiorado and especially his very intimate familiarity with the rust flora of the foot hills and plains about Denver, together with his highly enthusiastic and generous disposition, made the days memorable for the number and important character of the observations. Beside excursions immediately about Denver longer trips were taken through the Municipal Mountain Parks, to Pueblo, and to Boulder, all but the last by automobile with observations along the way. The rust flora of this region is the richest and most varied known to the writer, and the visit resulted in a large increase in knowledge regarding new forms and combinations. The identity of Puccinia Schedonnardi with $P$. Muhlenbergiae, the status of Aecidium Abroniae, Aecidium Liatridis and the aecia on Polygonum aviculare, heretofore erroneously associated with Uromyces Polygoni, were established, and much else accomplished. A visit to Mr. Bethel's garden, in which he carries out large numbers of open-air cultures, was most instructive as well as indicative of the highly valuable character of his studies.

The final stop (June I-2) of the journey was at Manhattan, Kans., where over thirty years ago Professor W. A. Kellerman brough to light a number of forms still imperfectly known. By the aid of Mr. L. E. Melchers and other members of the Agricultural College a fruitful reconnaissance of the vicinity was made, resulting especially in detection of the alternate form for the Aecidium on Allium, which had tentatively been assigned by different observers to no less than four very unlike telial forms.

Such excursions for observation as those just mentioned have been of inestimable value in securing knowledge for the successful prosecution of the culture work. Without numerous cultures the marvelous advance of recent years in the taxonomic study of American rusts would have been largely impossible. Moreover, without the most varied cultures brought about by observations in widely separated parts of the country the intricate 


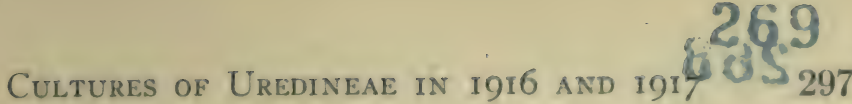

relationships, transcending all deductions derivable from morphological study alone, must have remained unrecognized, or in so far as dimly apprehended be wholly without demonstration.

A number of correspondents assisted in securing needed material for the season's work, and to them thanks are due. There were available 170 collections with resting spores, and 9 with active spores as in Aecidium and Gymnosporangium. Some 452 tests were made in a hanging drop to determine the germinating condition of the spores. Only 69 collections of resting teliospores could be brought to germination from which 182 sowings were made, and 17 infections secured. From the 9 collections of fresh spores 12 sowings were made, and 3 infections secured. The work was largely performed by Mr. C. C. Rees, a member of the regular staff of the laboratory.

Negative Results IN I9i6.-Of the various attempted cultures which failed to produce inoculations two are worthy of record.

I. Uromyces graminicola Burr. on Panicum virgatum L., sent by Mr. E. Bartholomew from Stockton, Kans., was sown April 25 on Euphorbia corollata, and again May 25 on the same host, in both instances with no apparent result. In previous seasons the same species was sown on a number of other hosts, ${ }^{3}$ but in the meantime from morphological and distributional data the conclusion had been reached that this form is probably correlated with Puccinia Pammelii on the same host, whose aecia are known to be on Euphorbia corollata. Other attempts at cultures should be made before abandoning the assumption.

2. Puccinia on Carex Backii Boott (C. durifolia Bailey) obtained by Mr. E. Bethel in February from near Denver, Colo., was sown April 7 on Ribes Cynosbati, Boltonia asteroides and Urtica gracilis, and again May 15 on the same hosts and on Eleagnus argentea and Artemisia dracunculoides. The same form obtained by Mr. Bethel in March from Boulder, Colo., was sown April 7, on $R$. Cynosbati, $B$. asteroides, and $U$. gracilis, and April 15, on R. Cynosbati, $U$. gracilis, and E. argentea.

3 See Jour. Myc. 12: 13. 1906; Mycol. 1: 232. 1909; 2: 220. 1910; 4 : 12. 1912. 


\section{$298 \frac{150}{270}$}

Another collection sent from Valentine, Neb., by Rev. J. M. Bates, was sown May 26, on $R$. Cynosbati, B. asteroides, $U$. gracilis and $E$ : argentea. All the sowings were without effect. All three collections gave fairly strong germination of the teliospores at the date of sowing.

Cultures have been attempted once before $\mathrm{e}^{4}$ on five hosts, all but one different from the above. The morphological characters of this form approximate those of Puccinia Grossulariae on various species of Carex, but nothing has yet been proven by cultures.

Successful Cultures in I9I6 SupPLementing PREvious WORK.- The culture of the following seven species adds valuable information in each case to the facts previously recorded.

I. Puccinia universalis Arth.-Material on Carex filifolia, collected by the writer May I8, I9I6, at Ogallala, Neb., was sown June 2, on Artemisia gnaphalodes. Pycnia were detected June 15, but doubtless appeared earlier, being obscured by the heavy tomentum of the plant, and were followed by a large number of aecia, first seen June 28. This rust has been cultivated a number of times before ${ }^{5}$ on various species of Artemisia, but only with telial material from Carex stenophylla. Carex filifolia, like $C$. stenophylla, occurs on semi-arid plains. It usually grows only three or four inches high, and in dense mats. It is locally known as "nigger-wool" or "black-root," from the tough, tangled mass of fine, black roots, resisting decay for a year or two when turned up by the plow and exposed to weathering.

2. Puccinia poculiformis (Jacq.) Wettst.-This very common stem rust of grasses and grains was grown on Berberis vulgaris from two collections made by Mr. G. E. Osterhout, Windsor, Colo., on March 2, one from Sporobolus cryptandrus, sown April 23, showing pycnia May 6, but not developing aecia, and the other from Elymus canadensis, sown May I5, showing pycnia May 25 and aecia June 6. Another collection on Agropyron Smithii made by Mr. E. Bethel, in Denver, Colo., March

4. Mycol. 2: 248. 1910.

5 For previous cultures see Jour. Myc. 14: 21. 1908; Mycol. 2: 224. 1910; and $4: 16.1912$. 


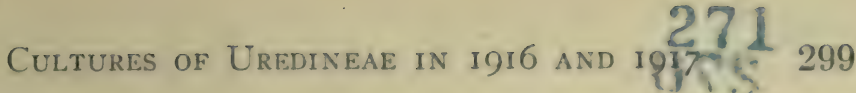

6, was sown on Berberis vulyaris on April 23, and began to show pycnia April 30 , and aecia May $4{ }^{\circ}$

3. Puccinia Rhamini (Pers.) Wettst.-A collection made by Mr. G. B. Posey in December, I9I 5, at Corvallis, Oregon, on Agrostis sp., was sown May II, on Rhammus Purshiana, and showed pycnia in fair numbers May 20, but made no further development, although the leaves remained healthy and in good growing condition for a considerable time.

4. Puccinia Distichlidis Ellis \& Ev.-This rust was found May 24 by Mr. Geo. E. Osterhout and the writer in great abundance on over-wintered Spartina Michauxiana in a field at Windsor, Colo., and entirely unmixed with any other rust known to occur on the same host. The spores had not yet germinated. Large groups of Steironema ciliatum nearby, the supposed alternate host, were already six or eight inches high and free from infection. The teliospores were sown on $S$. ciliatum in the greenhouse at Lafayette on May 30, and gave a heavy infection, showing pycnia June 4, and numerous aecia June Io. This result confirms the work of $1915^{7}$ and establishes the life cycle of the species beyond doubt. On June $12 \mathrm{Mr}$. Osterhout sent a fine collection of aecia on $S$. ciliatum from the place where the cultural material had been obtained, being the second field collection for the species, the previous one being made in North Dakota.

5. Puccinia Muhlenbergiae Arth. \& Holw. (P. Schedonnardi K. \& S.).-Telial material of this rust was found May 28 by Professor H. S. Jackson and Mr. E. Bethel, on Muhlenbergia gracillima, a low, tufted and fine leaved species growing on the arid plains near Pueblo, Colo., associated with Malvastrum coccineum, suspected of being an alternate host. A sowing was made on $M$. coccineum June 2 , which gave pycnia June 18 , and aecia June 25 , both in strong development.

Telial material of Puccinia Schedonnardi, on Schedomnardus paniculatus was obtained by Mr. Bethel, Professor Jackson and the writer at Pueblo, Colo. After the preceding trial showed signs of success, a striking resemblance was noticed between the

B For previous cultures see Jour. Myc. 8: 53. 1902; 11: $57.1905 ; 12: 17$. 1906; 13: 198. 1907; 14: 16. 1908; Mycol. 2: 227. 1910; and 4: 18. 1912.

i See Mycol. 8: 136. 19г6. 
two grasses in size and habit of growth and also between the gross appearance of the rusts they bore. The resemblance was furthermore found to extend to the microscopic features of the rusts. This led to sowing the teliospores upon $M$. coccineum, which was done June 23 , and resulted in production of pycnia June 30 , and aecia July II. Although not so strong devèlopment as in the preceding case the gross and microscopic appearances were the same, and left no doubt that $P$. Schedonnardi is to be considered synonymous with $P$. Muhlenbergiae, a species of many races and hosts. ${ }^{8}$ The middle of September subsequent to these cultures a letter was received from Mr. E. Bartholomew, of Stockton, Kans., in which he gives the following account of observations, most strongly confirming the conclusion reached from cultures. He says: "Standing in the doorway of the Mt. Nebo Presbyterian Church, three and one half miles south of our home, on June II, I9I6, I noticed, very close to the building, a large number of plants of Malvastrum coccineum profusely attacked by Accidium malvicola Arth., and on examining the grasses growing among the Malvasirum there was found teleuto material on dead Schcdonnardus, and on the developing young leaves and sheaths abundant uredo of Puccinia Schedonnardi! Continued examinations for several weeks, as the Puccinia developed into the III, led me to conclude beyond a peradventure that the aecium is no more nor less than $I$ of this fungus as the grass was infected only in the near reach (not to exceed one rod) of the Malvastrum. While I have collected this Puccinia several times in the past ten years I have not come across Aecidium malvicola since May, I904 (F. Col. No. 1905)."

6. Puccinia subnitens Diet.-This rust is probably the most remarkable known for the number and diversity of its aecial hosts. The present addition of two families to the aecial hosts as previously recorded is entirely the result of information supplied by Mr. E. Bethel, who had made repeated observations of propinquity in the field, and verified his assumptions of relationship by cultural tests in his garden in Denver.

Telial material on Distichlis spicata obtained by Professor $\mathrm{H}$.

8 For previous cultures see Jour. Myc. II: 51. 1905; 13: 192. I907; Mycol. I: 251. 1909; 2: 226. 1910; 4: 18. 1912; and 7: 82. 1915. 


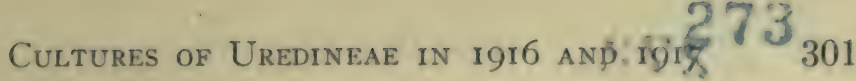

S. Jackson at Denver, Colo., May 26, was sown June 9 on Abronia fragrans (family Nyctaginaceae) and Polygonum aviculare, with infection only on the Abronia, on which pycnia began to appear June I5, and aecia June 19, in abundance. A collection on the same host made by the writer at Ft. Collins, Colo., May 23, was sown on Polygonum aviculare (family Polygonaceae) June 23, giving pycnia June 30 , and aecia July 3 , showing strong development. ${ }^{\circ}$

7. Puccinia Liatridis (Ellis \& And.) Bethel.-After repeated assurances from $\mathrm{Mr}$. E. Bethel that he had found a rust on Koeleria cristata that would produce aecia on Liatris, and had cultured it in his garden, and having received material for study, successful sowings were made fully confirming his contention. A telial collection made by Mr. Bethel April 22, at Boulder, Colo., was sown May 4, on Laciniaria punctata (Liatris punctata), showing pycnia May 15, and aecia May 22. Another collection made by Mr. Bethel and the writer May 30, at Boulder, Colo., was sown on $L$. punctata June 23 , showing pycnia July 3 , and aecia July 7 . The aecia have long passed under the name of Aecidium Liatridis Ellis \& And., but the telial form has only recently been separated from the several other rusts on Koeleria in a paper by Bethel, in which he gives an account of his cultures, but which has not yet been received by the writer in printed form.

SUCCESSFul CUltures in I9I6 REPORTED NOW FOR THE FIRST TIME.-The following species have never been cultivated in America or elsewhere, so far as the writer knows.

I. Uromyces Sporoboli Ellis \& Ev. (Aecidium alliicolum Wint.).-On June I the writer in company with Messrs. L. E. Melchers, G. W. Putnam and H. S. Jackson explored a number of centers of infection of Allium stellatum showing aecia, found in great abundance in a field adjoining the campus of the Agricultural College at Manhattan, Kans. In one place a few uredinia were found on seedling grass about three inches high, ascertained to be Sporobolus vaginaeflorus, while over-wintered telia were

9 For previous cultures see Bot. Gaz. 35: 19. 1903; Jour. Myc. Ir: 54. 1905; 12: 16. 1906; 13: 197. 1907; 14: 15. 1908; Mycol. x: 234. 1909; 2: 225. $1910 ; 4: 18,54.1912$; and $8: 135.1916$. 


\section{ris \\ 302

found on the dead plants of the same annual grass, all pointing to a genetic connection. Hard clumps of earth with the young grass were taken at some distance from the aecial areas and brought to the greenhouse at Lafayette. Whole plants of the Allium, in size and appearance much resembling the garden onion, on which were abundant aecia, were also taken, and on June 6 a sowing was made on the seedling grass, resulting in uredinia, first noticed June 2I. Another lot of Allium plants from the same field, bearing aecia, was sent by Mr. Melchers about two weeks later, and another sowing made June 22, giving uredinia June 29. Neither cultures developed telia, owing to the difficulty in keeping the grass growing properly in the greenhouse. No uredinia appeared on any of the grass not used for inoculation.

The first cultural attempt with the telia of this rust was made fourteen years ago, ${ }^{10}$ and again in 1910 and 1912 , many hosts being used.11 In 1912 the attempt was made to follow up observations by Mr. E. Bartholomew at Stockton, Kans., by sowing on Allium reticulatum, among other hosts, but with no success. Again this year Mr. Bartholomew sent telia on Sporobolus neglectus, which were sown on $A$. reticulatum and $A$. canadense, but again without success. No reason can be assigned for the failures.

2. Puccinia Vernoniae B. \& C.-A collection of this rust on dead stems of some undetermined species of Vernonia, obtained by Mr. C. H. Crabill at Cliffview, Va., March 9, was forwarded by Dr. F. D. Fromme. The sori were numerous and large, ranging from 0.5 to $1.5 \mathrm{~cm}$. long. A sowing was made on the leaves of an undetermined species of Vernonia, which resulted in an abundance of pycnia, and some uredinia, but growth ceased before telia were formed. Exact dates were not secured, but the sowing was made about April 30, and the leaves removed for the herbarium on July 6 , bearing pycnia and uredinia. This is the first record for pycnia of this very common rust. The life cycle shows that the species belongs in the genus Bullaria, in which it becomes Bullaria Vernoniae (B. \& C.) comb. nov.

10 Bot. Gaz. 35 : Ir. 1903.

11 See Mycol. 4: 13. I912; and 7:66. 19r5. 
275

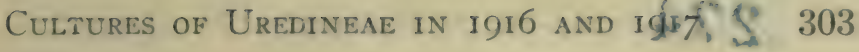

\section{SUMMARY FOR I9I6}

The following is a complete list of the successful cultures made during the year I9I6. Those of the first series are species which have been previously cultured, but those of the second list have never been reported before.

\section{A. Species Previously Reported}

I. Puccinia universalis Arth. Teliospores from Carex filifolia Nutt., sown on Artemisia gnaphalodes Nutt.

2. Puccinia poculiformis (Jacq.) Wettst.-Teliospores from Sporobolus cryptandrus (Torr.) A. Gray, Agropyron Smithii Rydb. and Elymus canadensis L., sown on Berberis vulgaris L.

3. Puccinia Rhamni (Pers.) Wettst.-Teliospores from Agrostis sp., sown on Rhamnus Purshiana DC.

4. Puccinia Distichlidis Ellis \& Ev.-Teliospores from Spartina Michauxiana Hitchc., sown on Steironema ciliatum (L.) Raf.

5. Puccinia Muhlentergiae A. \& H. ( $P$. Schedonnardi Kellerm. \& Sw.).-Teliospores from Muhlenbergia gracillima Torr., and from Schedonnardus paniculatus (Nutt.) Trel., sown on Malvastrum coccineum (Pursh) A. Gray.

6. Puccinia subnitens Diet.-Teliospores from Distichlis spicata (L.) Greene, sown on Abronia fragrans Nutt., and Polygonum aviculare $\mathrm{L}$.

7. Puccinia Liatridis (Ellis \& And.) Bethel.-Teliospores from Koeleria cristata (L.) Pers., sown on Laciniaria punctata (Hook.) Kuntze.

\section{B. Species Reported Now for the First Time}

I. Uromyces Sporoboli Ellis \& Ev. (Aecidium alliicolum Wint.).-Aeciospores from Allium stellatum Ker., sown on Sporobolus vaginaeflorus Torr.

2. Puccinia Vernoniae B. \& C.-Teliospores from Vernonia sp., sown on the same host. 


\section{Cultures in I9I7}

No trips for observation were taken during this year, and the usual amount of time bestowed on the cultures was greatly reduced. About 25 collections with resting spores and 6 with active spores, the latter all forms of Aecidium, were available for the tests. About I2O drop cultures were made from the sets of resting spores, showing that 15 of the collections were more or less viable at the time. From the fifteen collections I4 successful inoculations were secured, IO3 sowings having been made. The work was partly done by Mr. C. C. Rees and partly by Dr. E. B. Mains, members of the laboratory staff.

Negative Results in 1917.-It seems worth while to call attention to three attempts which wholly failed, with the hope that some one may be aided in solving the problems involved.

I. Puccinia triticina Erikss. on Triticum vulgare Mill. was obtained from the border of a wheat field in September, I916, by Mr. C. C. Rees, and sown on Clematis Flammula L., May I7 following, but with no result. The teliospores, however, were germinating very feebly. The conclusion was reached some two years ago from morphological and other data, that the common leaf rust of wheat is a race of the common P. Agropyri E. \& E., occurring upon many wild grasses. P. Agropyri from Agropyron glaucum was cultured on Clematis Vitalba L. in Germany by Dietel in I892. In America cultures have shown races to exist in eastern United States between Bromus ciliatus and Clematis virginiana, in Colorado between Elymus canadensis and Agropyron Smithii and C. ligusticifolia, in Texas between Elymus virginicus and C. Drummondii, and in North Dakota between $E$. canadensis and Anemone cylindrica. As Clematis Flammula and C. Vitalba are almost the only common Ranunculaceous plants through the wheat growing regions of southern Europe, northern Africa and western Asia, an area that probably includes the home of the original wild wheat, the assumption is reached that one or both these hosts can be made to bear aecia from $P$. triticina under favorable conditions.

2. Puccinia emaculata Schw. on Panicum capillare L. was sown May 8 on Euphorbia corollata, and May 9 on E. commutata 


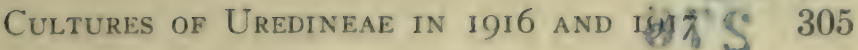

with no infection, from material obtained by Prof. H. S. Jackson in southern Indiana. Another collection secured by Dr. E. B. Mains at Lafayette, Ind., was sown May 17 on E. corollata, and again May 24, June 5 and 13 , on E. Ipecacuanhae, with no infection. In each case the teliospores showed fair germination and the hosts were in excellent condition. Judging from morphological and host data these species of Euthorbia would be probable aecial hosts, but all attempts at cultures ${ }^{12}$ have so far failed. I am indebted to Prof. J. B. S. Norton, botanist of the Maryland Agricultural Experiment Station, for a number of serviceable plants of E. Ipecacuanhae.

3. Pucciniastrum Hydrangeae (B. \& C.) Arth., on Hydrangea arborescens L., collected by Dr. E. B. Mains at Lafayette; Ind., March 3I, I917, was sown May 12 on Tsuga canadensis, Abies balsamea, Abies concolor, and Picea canadensis, with no infection. Although no clues had been obtained from field observation, yet these genera of hosts include all on which any species of Pucciniastrum has yet been grown, and the teliospores were germinating freely, so there had been reasonable hopes of success.

SUCCESSFUl CULTURES IN I9I 7 SUPPLEMENTING PREVIOUS WORK.-The successful attempts to connect the aecia on Iris versicolor and on Rudbeckia laciniata with telial forms are the culmination of efforts extending over several years, in which a number of persons have aided. Similar efforts to connect the localized aecia on Houstonia caerulea and on Capnoides montanum have so far been without success, that is, for this laboratory.

I. Puccinia Majanthae (Schum.) Arth.-This year for the firs: time American material of this widely distributed and highly specialized rust has been cultured. The work was first done by Prof. H. H. Whetzel at Ithaca, N. Y., in verification of observations at North Spencer, N. Y., made during the season of I9r6 by Prof. Whetzel and Prof. H. S. Jackson. The account of the work has not been published at the time of this writing. Both before and after Prof. Whetzel had obtained his results he sent

12 For previous attempts see Bot. Gaz. 35: 12. 1903; Jour. Myc. 8: 52. 1902; 10: 10. 1904; 12: 12. 1906; 13: 192. 1907; 14: 11. 1908; Mycol. 1: 230. $1909 ; 7: 65.1915 ;$ and $8: 127.1916$. 
material and gave all possible aid in duplication of his work here in Indiana.

The teliospores from Phalaris arundinacea, obtained by Prof. Whetzel at North Spencer, N. Y., Nov. 6, I916, were sown May $\mathrm{I} 6$ on Iris versicolor, and again May I7 on I. versicolor, and also on Polygonatum commutatum, Vagnera racemosa, Convallaric majalis and Allium stellatum. On May I9 they were sown on Polygonatum biflorum and May 20 on Maianthemum canadense. Only infection took place on Iris, the first sowing showing copious pycnia on May 2I and aecia on May 30, while the second sowing gave pycnia May 23 and aecia June I. The only previous similar attempt was made in the cultures for $1910^{13}$ when telial material from South Dakota was sown on Polygonalum commutatum. Vagnera stellata, Convallaria majalis, Uvularia grandiflora and Trillium cernuum with no infection. It is likely that Puccinia Majanthae has aecia on all the hosts named, but if so the occurrence of strongly pronounced biological strains prevented infection in the two tests.

2. P.uccinia subnitens Diet.-For a number of years the aecia on Capnoides (Corydalis) known as Aecidium fumariacearum Kellerm. \& Sw., have been associated with the telia on Distichlis spicata from morphological and host considerations, but the cultures were not made until the present season, although several times attempted. In June Mr. E. Bethel sent aecia on C. montanum grown in his garden from teliospores on D. spicata secured at Berkeley near Denver, Colo.

Some of the same collection of telia was transmitted by $\mathrm{Mr}$. Bethel and on June 14 the teliospores were sown on Abronia fragrans, Capnoides montanum and Chenopodium album, with infection only on the last host, giving pycnia June $2 \mathrm{I}$, and aecia June 23. Another sowing was made June $2 \mathrm{I}$ on $C$. montanum, but gave no infection. Possibly the lateness of season prevented success with the Capnoides although the more susceptible Chenopodium was infected.

3. Uromyces seditiosus Kern.-Observations were made by Dr. F. D. Fromme and the writer in I9I4 at Houston, Texas, which appeared to show that this rust sometimes forms aecia on 
Houstonia caerulea, and since then efforts have been made to secure suitable material with which to make tests. With this in view teliospores from a collection on Aristida ramosissima made by Prof. H. S. Jackson at Elberfield, Ind., were sown on $H$. caerulea, but without result. Again teliospores from a collection made by Prof. C. D. Learn on A. basiramea at Stillwater, Okla., were sown May 24 on $H$. caerulea, Plantago Rugelii, $P$. lanceolata and $P$. aristata, with infection only on the last two hosts, giving pycnia June 4 and aecia June 7 , both in abundance. ${ }^{14}$

4. UROMYCES PERIGYNIUS Halst.-Aecia have been collected on Rudbeckia laciniata in the central west from Montana to Wisconsin, Nebraska and Indiana for which telial connection has been sought for some time. ${ }^{15}$ Field observations made by Prof. E. W. D. Holway at Excelsior near Minneapolis, Minn., during I9I6, pointed definitely to telia on a Carex. The material sent by Prof. Holway was $U$. perigynius on $C$. sparganioides, and was sown May 17 on Solidago canadensis, Aster lateriflorus and Rudbeckia laciniata, with exceedingly abundant infection on the last host, showing pycnia May 2I and aecia May 29. The Solidago and Aster remained free of rust. Evidently Rudbeckia acts as a racial host for this rust parallel with Aster and Solidago.

SUCCESSFUl CULTURES IN I9I7 REPORTED NOW FOR THE FIRST TIME.-Both of the following species introduce questions of relationship which it is impossible at the present time fully to answer.

I. Puccinia Sporoboli Arth.-Observations were made by Dr. J. F. Brenckle at Kulm, N. Dak., which pointed distinctly to the connection of this rust with aecia on Lilium umbellatum, and material consisting of telia on Sporobolus heterolepis and bulbs of L. umbellatum were sent in the fall of 1916 , with which to test the matter. Further telial material was sent the following spring. A sowing was made April 26 and again April 30 and May I on a garden lily, L. elegans Thunb., closely resembling L. umbellatum, the Dakotan plant not being in leaf, but with no infection. On May I6 two sowings were made on the same host and also on

14 For previous cultures on Plantago see Bot. Gaz. 35: 17. 1903.

15 For unsuccessful tests see Jour. Myc. 12: 12, 13, 14, 25. 1906; 13: 191, 192, 202. 1907; Mycol. I: 229, 230, 251. 1909; 2: 218. 1910; 4: 9, 12, 13, 28. 1912. 
L. umbella:um, with no infection on the first, and with abundant infection on the latter, showing pycnia May 23 and aecia May 29. Another sowing was made May 29 on Vagnera stellata, Uvularia grandiflora, Maianthemum canadense, Allium stellatum, all with no infection, and also on $A$. Nuttallii giving pycnia June 4 , and aecia June 9 , and on $A$. cernuum giving pycnia June 9, and aecia June $\mathrm{I} 2$, both in abundance. Sowings June 5 on $A$. stellatum and A. canadense gave no result.

Although the host of this rust is one of the principal prairie grasses of the western plains, yet the rust has been collected only in three localities, one at Decorah, Iowa, in 1884, I901 and 1902, one at Ewing, northwestern Nebraska, in 1899, and the third a recent find at Kulm, N. Dak. It differs from all other American grass rusts in having the pores of the urediniospores near the hilum.

Last year Uromyces Sporoboli E. \& E. on Sporobolus vaginaeflorus was connected with aecia on Allium from Kansas material, The aecia from the two species seem to be indistinguishable by any technical character. The suggestion at once arises that the two forms may be genetically correlated. Examination of the telia supports this hypothesis, for the mesosporic teliospores of the Puccinia are indistinguishable in size and appearance from the teliopores of the Uromyces, but on the other hand the urediniospores of the Puccinia are considerably smaller than those of the Uromyces and somewhat thinner walled. The greatest difference, however, lies in the arrangement of pores of the urediniospores. In the Puccinia they are three or four and basal, while in the Uromyces they are four and equatorial.

A particularly close correlation appears to exist between Puccinia Cryptandri E. \& B. on Sporobolus cryptandrus and U. Sporoboli, both in uredinia and telia, although the urediniospores of $\mathrm{P}$. Cryptandri are inclined to assume a winter resting condition with thicker walls. Unfortunately no suitable culture of $P$. Cryptandri has yet been made, and the aecia are unknown, but it may be assumed that they will be found to occur on Allium or a closely related host.

Putting together what is now known regarding these three forms of rust on Sporobolus and comparing with what is known of the 
forms of rust on Carex going to Ribes, P. Grossulariae (Schum.) Lagerh. ( $P$. uniporula Orton $),{ }^{16}$ we seem justified in assuming that the grass forms in question represent one species made up of morphologico-physiological races, just as the sedge forms appear to do, but the proof is not so complete. The marked differences in the urediniospores of $P$. Sporoboli, P. Cryptandri and U. Sporoboli, are all such as can be harmonized with the assumption that the three forms represent only the races of one species, although it does not seem necessary now to go into the required explanation to make the matter perfectly clear. However, for convenient taxonomic reference, and until the relationship is more firmly established, it will be best to treat $P$. Sporoboli, P. Cryptandri and $U$.Sporoboli as independent species.

2. Uromyces on Spartina.-Field observations by Dr. J. F. Brenckle were made during the spring of 1915 at Kulm, N. Dak., which seemed to indicate connection between aecia on Vagnera stellata and the common Uromyces on Spartina. Such a connection seemed to be strengthened by later observations. On May 31, 1916, Dr. Brenckle says in a letter to the author: "Yesterday I wcnt over my station carefully and found the infected plants of Smilacina [Vagnera] invariably accompanied by rusted Spartina. I noted also a number of well infected leaves, each of which was overhung and scraped on by a rusted leaf of Spartina. As the infection of Smilacina is only in the pycnial state it probably has not spread away from its original telial source. The Smilacina is abundant but the infected plants are sharply confined to those patches also inhabited by the Spartina. One such patch had plants of Smilacina which were not infected. I was disappointed that my theory was not proving correct until I noticed that the Spartina had no rust."

With such strong circumstantial evidence the success of cultures un lertaken with telial material supplied by Dr. Brenckle still came as a surprise, for three or four races of the Uromyces on Spartina are already. well known having aecia on three families of dicotyledonous hosts, and no heteroecious rust has heretofore been discovered having aecia on both monocots and dicots.

On May I I teliospores from Spartina Michauxiana were sown 16 Mycol. 4: 13. 1912; 7: 66, 78. 1915. 
on Vagnera (Smilacina) stellata, Polygonatum biflorum and Steironema ciliatum, with infection only on the first two, giving pycnia May I8, and aecia May 25, both in the greatest abundance and vigor. Another sowing was made May 19 on Polygonatum biflorum, showing pycnia May 28 and aecia June 7 , also on $P$. commutatum, showing pycnia May 27 and aecia June 6, and furthermore on the following which were not infected: Uvularia grandiflora, Maianthemum canadense, Vagnera racemosa, Iris versicolor and Trillium recurvatum. Still another sowing was made May 23 on Steironema lanceolatum without infection, and May 29 on $U$. grandiflora, $M$. canadense, $V$. racemosa and $V$. stellata, with infection only on the last, only pycnia showing June 6 , doubtless owing to the lateness of the season.

Upon studying the microscopic characters of the material here recorded the form is seen to readily fall into the species given in the North American Flora ( $7: 23 \mathrm{I})$ as Nigredo Polemonii (Peck) Arth. The aeciospores on Vagnera and Polygonatum are much larger ( $18-29$ by $19-35 \mu$ ) than those on the same hosts which have been assigned to Puccinia Majanthae (Schum.) Arth. (I 5-2I by $16-27 \mu)$, and have thicker walls, being characters by which the two species may be separated. A collection on Vagnera stellata from the valley of the Teton in northern Montana was some years ago made a new species under the name of Aecidium magnatum Arth., on these same characters. The aeciospores are somewhat larger than those on the other races of the Uromyces on Spartina, although there is a gradation in size within certain limits for the four races. In fact the four races of this species exhibit not only physiological specialization, but a certain amount of morphological differentiation of both aecia and telia, together with considerable geographical segregation.

For convenience in discussion of these races there would be some advantage to have distinctive names. The following outline will fairly well show the present morphologico-physiological divisions with geographical distribution, and corresponding names.

Uromyces Polemonin (Peck) Barth. (Nigredo Polemonii Arth.)

Aeciospores $14-19$ by $1^{-23} \mu$, on Caryophyllaceae.

Teliospores generally broad and rounded above. 
I. Salt marshes of coast, Nova Scotia (III also in Delaware and Florida), and Southern California (III not known on Pacific coast)........................ Uromyces Spartinae Farl.

Aeciospores ${ }_{15}-23$ by ${ }_{16} 6-26 \mu$, on Polemoniaceae.

Teliospores narrow and mostly acuminate above.

I. Dry plains and thickets, Indiana and Wisconsin to North Dakota and foothills of Colorado (III same).

Uromyces acuminatus Arth.

Aeciospores 16-23 by 18-29 $\mu$, on Primulaceae.

Teliospores mostly blunt or truncated above.

I. Moist plains, Central Indiana to Central Wisconsin and foothills of Colorado and Wyoming (III same).

Uromyces Steironematis nom. nov.

Aeciospores $18-30$ by $19-35 \mu$, on Convallariaceae.

Teliospores generally blunt or acute.

I. Lake or river banks, Buffalo, N. Y., to Central Montana and Nebraska (III North Dakota)..Uromyces magnatus comb. nov.

The collection used for the initial culture may be taken as type of U. Steironematis. It was collected at Palmer, Neb., March 22, I905, on Spartina Michauxiana Hitchc., by Rev. J. M. Bates, and was successfully sown May 26, 1905, on Steironema ciliatum. ${ }^{17}$

The forms of the teliospores and the habitats of the four forms are to be taken only as the general expression of the races, and are of no real diagnostic value except as associated with other characters. Both acuminate and rounded teliospores can usually be found in the same sorus, but the impression given by a microscopic mount from specimens of the first race is generally that the spores are prevailingly rounded above, from the second race, acuminate, etc.

The aecia of $U$. Spartinae have been collected on Arenaria and Tissa in Nova Scotia and southern California; those of U. acuminatus on Collomia, Gilia, Phlox (three species) and Polcmonium, in Colorado, Indiana, Iowa, Minnesota, Nebraska, North Dakota, South Dakota and Wisconsin; those of $U$. Steironematis on Dodecatheon and Steironema, in Colorado, Illinois, Iowa, Kansas, Nebraska, North Dakota, South Dakota, Wisconsin and Wyoming; and those of $U$. magnatus on Polygonatum (two species) and Vagnera (two species), in Illinois, Iowa, Minnesota, Montana, Nebraska, North Dakota, South Dakota and Wisconsin.

17 Jour. Myc. 12: 25. 1906. 
Exsiccati material representing aecia has been issued as follows: for U. Spartinae none; for U. acuminatus, Barth. F. Columb. 2605, Barth. N. Am. Ured. 597, Brenckle, F. Dak. I02, Ellis, N. Am. F. 1008, Rab.-Wint. F. Eur. 3637; for U. Steironematis, Barth. F. Columb. 2288, Brenckle, F. Dak. 134 , 259, Ellis, N. Am. F. I424, Sydow, Ured. 270I; and for U. magnatus, Barth. F. Columb. 4I62, 4467, 4764, Barth. N. Am. Ured. 66I, I074, II70, I269, Brenckle, F. Dak. I, 226, Griff. West Am. F. 243, Sydow, Ured. 2298.

\section{SUMMARY FOR 1917}

\section{A. Species Previously Reported}

I. Puccinia Majanthae (Schum.) Arth.-Teliospores from Phalaris arundinacea L., sown on Iris versicolor L.

2. Puccinia subnitens Diet.-Teliospores from Distichlis spicata (L.) Greene, sown on Chenopodium album L.

3. UROMyCes seditiosus Kern.-Teliospores from Aristida basiramea Engelm. sown on Plantago aristata Michx. and $P$. lanceolata L.

4. Uromyces PERIgynius Halst.-Teliospores from Carex sparganioides Muhl., sown on Rudbeckia laciniata L.

B. Species Reported Now for the First Time

I. Puccinia Sporoboli Arth.-Teliospores from Sporobolus heterolepis A. Gray, sown on Allium cernuum Roth., A. Nuttallii S. Wats., and Lilium umbellatum Pursh.

2. Uromyces magnatus Arth.-Teliospores from Spartina Michauxiana Hitchc., sown on Polygonatum biflorum (Walt.) El1., P. commutalum (R. \& S.) Dietr., and Vagnera stellata (L.) Morong.

Purdue University,

LAFAYETTE, Indiana. 


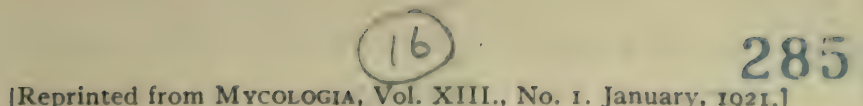

[Reprinted from Mycologia, Vol. XIII., No. 1. January, 1921.]

\section{NINETEEN YEARS OF CULTURE WORK ${ }^{1}$}

\section{J. C. Arthur}

A series of culture experiments with the Uredinales was begun by the writer in 1899 , and continued under the auspices of the Indiana Agricultural Experiment Station without interruption until 1917, making nineteen consecutive years in which this method of research was consistently pursued. The results of the work were embodied in fifteen reports, printed in the Botanical Gazette, Journal of Mycology, and Mycologia. It is now proposed very briefly to review the work, in order to set forth some of the objects accomplished, and especially to point out the more important of the changing conceptions of the problems forming the ground plan on which the work was projected.

The cultures were not undertaken as part of a distinct thesis or circumscribed problem. They were rather the aids in a general taxonomic study of American rusts, which was directed toward supplying a technical description as complete as possible for every species of Uredinales in North America recorded in literature or known to the writer. This ambitious undertaking was definitely begun sometime in the nineties at the invitation of the editors of the North American Flora.

Beginning with my first taxonomic work on the rusts in 1882 it had seemed to me highly desirable for the purposes of a full tech. nical description of species, that every part of these microscopic plants, capable of supplying diagnostic characters, should be uniformly considered, quite as much as are the stems, leaves, inflorescence, flowers, and fruit of higher plants, and that every means should be taken to arrive at a clear understanding of the identity and relationship of the various forms and species. No effort should be spared, it was believed, to make the name applied to any form embrace also the transformations and variations

1 Contribution from the Botanical Department of Purdue University Agricultural Experiment Station. 
which that form undergoes in passing through its whole life cycle. Many rusts are commonly collected in only one or two stages of their development, or the several stages are taken as independent objects, and to grow such rusts so as to keep them under direct observation and be able to note the succession of stages seemed highly desirable, and especially so for the heteroecious species which pass their gametophytic and sporophytic stages upon wholly unlike and unrelated hosts. It was natural, therefore, to direct chief attention, especially at first, toward unraveling the tangle of heteroecious forms.

Nobody knew how many rusts were to be found on the North American continent and its islands. There were possibly a thousand or more names in existence, but how many of these names applied to single and independent life cycles, and how many to parts of cycles, or were synonyms, no one had attempted to say. It was, in fact, only with the existing names that $I$ had to do. It was no part of my problem to discover new species, or to give new names, either in preparing manuscript for the North American Flora, or in conducting cultures, except in so far as these were required for the systematic development of the work. Many longer or shorter excursions were made during the progress of the cultures, some of them a thousand miles or more, but they were all for the purpose of making field observations upon known species, and in no case for making discovery of new species. The new species that were found were an incidental result.

The first year of the culture work, that of 1899, was very encouraging, and developed no particular difficulties calling for solution. So far custom was followed in the application of names, and it had not been necessary to apply any formula to decide what constituted a species. The assumption that forms on the same or closely related hosts, having no striking morphological differences, were of one species seemed a sufficient hypothesis, and the corollary necessarily followed that cultures would show the range of hosts for each species, as well as serve to demonstrate the stages and spore-forms in the life cycle. Certain features in connection with the common Euphorbia rust did indicate that difficulty might be found in the application of the 
corollary, and this indication became more pronounced during the year following.

In 1902 three species of Euphorbia of unlike appearance and growth habits were found to bear non-interchangeable rusts, which were tentatively considered to present races of Uromyces Euphorbiae C. \& P., and with the more confidence because no well-defined morphological distinctions could be detected. Subsequent studies strengthened this view of races, and the idea of races from this time on was constantly kept prominently in mind. The attempt to evade or simplify taxonomic and cultural difficulties by treaţing such races or biological strains as species, as Tranzschel ${ }^{2}$ subsequently did with these same Euphobia forms was not favored.

It was also in 1902 that the Helianthus rust was grown with indication of races, developed further in the following year, and brought to a climax in 1904, with the conclusion that a number of more or less well established races occur in Puccinia Helianthi Schw., having Helianthus annuus as a bridging species, following the lead of Marshall Ward ${ }^{3}$ in his study of the brome rusts. No further considerable effort was made to study races in autoecious species, or to pick out bridging hosts, as it was held that to ascertain the identity of species was as great a task as could be undertaken in this series of cultures, and that studies leading to the separation of a species into varieties, races, forms, or other subclasses, although of much biological and often of great economical interest, must be left for other time and hands.

The problems of the Carex rusts came early into view. In I9OI and 1902 the three remarkable co-species, having telia on various species of Carex and aecia on species of Aster, Solidago and Erigeron respectively were repeatedly grown from telial material, and were called Puccinia Caricis-Asteris, P. CaricisSolidaginis, and $P$. Caricis-Erigerontis. As no single collection of teliospores was found that would infect more than one of the genera named, the forms were tentatively considered to be species and given distinctive names, followng the brilliant cultural methods of Klebahn in Germany, Plowright in England, and

2 Ann. Myc. 8: I-35. 1910.

3 Ann. Myc. I: 150.1903 . 
others, although a careful comparison of the three forms made it seem " not improbable that the three represent more correctly the biological variations of one species," as was stated at the time. In the further study of these forms it was thought that the telial stage might be found to be restricted to certain species of Carex, or to particular sections of the genus, as was believed to be true of the European Carex rusts, which assumption in the case of the American forms, however, could not be established in any definite way. The hosts were shown finally to be even less restricted than supposed, as the Aster form was eventually carried over to Euthamia for its aecia and to Dulichium for its telia.

The necessity soon became acute to find criteria by which to judge of the standing of species among the rusts, and all the more so because the manuscript was now under preparation for the North American Flora. It was soon decided that, for the purposes of the Flora, morphological characters must be the final test for species. Yet for purposes of study outside of taxonomy it might be serviceable and desirable to maintain the so-called biological or physiological species in any rank desired, but they ought not to be recognized as species proper in taxonomic classification. Consequently in 1912 the three Carex forms were com. bined with certain European forms under the name Puccinia extensicola Plowr., a name which has been supplanted by $P$. Asterum (Schw.) Kern, since the cultural series closed. Furthermore, the cultures of 1913 disclosed that $P$. vulpinoidis with its covered telia had its aecia on Solidago, and was a part of this same species heretofore known only with naked sori, making the much emphasized character of covered telia a secondary one to be associated principally with the host.

Thus the idea of species among the rusts grew into a far more definite, although more complex form, than could have been possible without the aid of cultural studies. A liberal view was now also required regarding hosts, and also the stress on certain morphological characters called for modification, but the end was not yet.

In I9Io a number of cultures with the Carex rust, Uromyces perigynius, revealed a remarkable parallelism between this species 
and Puccinia extensicola. Aster and Solidago races came to light, not however quite so well stabilized in some instances as with the corresponding Puccinia races, for in one case sowings of teliospores from the same Carex collection were made to grow on both Aster and Solidago. The two species, one of Uromyces, the other of Puccinia, were subjected to an extensive microscopical study, and no marked differences could be found between their several corresponding spore-forms, except in the septation of the teliospores. This unity of structure had already been observed regarding the aecia and aeciospores when a preliminary culture of the Uromyces was made seven years before. From the microscopical evidence, united with much collateral evidence, the following statement was made in the discussion of I9I0, which holds true to the present time: "As the aecia and uredinia of the two groups [of host-races], one under the genus Puccinia and the other under Uromyces, are indistinguishable, and as the teliospores of the Uromyces agree with the one-celled spores of the Puccinia [mesospores] and also with the two-celled spores in all characters except number of cells and consequent length of spore, the former doubtless are morphological races of the latter. Relationship could be shown better by putting all of these forms under one specific name, and designating the several races by varietal names. But in the present state of taxonomy of the rusts it is more convenient to dispose of them under the two genera : Puccinia and Uromyces."4

If any further illustration were needed to show that Puccinia and Uromyces were not only parallel genera but actually identical, it was supplied by the cultures of the following year, I9II. During this season successful cultures on Atriplex hastata of both Uromyces Peckianus and Puccinia subnitens, each grown from teliospores on the grass, Distichlis spicata, obtained from widely separated localities, gave rise to aecia that appeared to be indistinguishable. A morphological study of these two so-called species has been reported by C. R. Orton in his article on "Correlation between Puccinia and Uromyces,"s in which he finds a

4 Mycologia 4:22, 1912.

5 Mycologia 4: 199. 1912. 
slight difference in size of the urdiniospores, and, of course, in the teliospores a difference in number of cells and consequent size. He points out, however, that these differences are such as are to be expected in other similar cases. The comparison of these two forms of Distichlis rust, as to morphology, hosts and distribution, is an interesting topic, which need not be pursued further here.

If the Carex-Aster-Solidago-Erigeron studies supplemented by studies with the Distichlis rust, opened up new views of the species question in relation to host influence and teliosporic dimorphism, so did the Carex-Ribes studies disclose new views in another direction. The first cultures were in I901. As the results of sowing teliospores on Ribes gave peculiarly small and pale aecia, it was thought that an unrecognized species had been found, which was called Puccinia albiperidia. Whether this form was distinct from the common Carex-Ribes rust of the fields, distinguished as $P$. Grossulariae, and whether American forms were distinct from European forms, of which Klebahn had recognized five, were questions which received attention from year to year as opportunity permitted. In this study Dr. Klebahn graciously consented to lend assistance, and during the two seasons of 1904 and 1906 made cultures at Hamburg, Germany, from telial material supplied by the writer.

Just as the problem seemed solved, and Dr. Klebahn ${ }^{6}$ and myself had independently arrived at the conclusion that in both Europe and America only one heteroecious species occurred, which possessed a number of strains or races, it was discovered by C. R. Orton, ${ }^{7}$ while assisting with the rust studies, that the original material of $P$. albiperidia onCarex pubescens, as well as that on a number of American species of Carex similar to $C$. gracillima, possessed urediniospores with only one basal pore, in part at least, instead of the usual three or four equatorial pores. Again the Carex-Ribes rusts of Amercia seemed to fall into two species, not based on differences in the aecia this time; but on differences in the urediniospores. From I9I0 onward the question in this connection was whether or not the same species of rust

6 Zeits. Pflanzenkr. 7 : 132-134. 1907.

7 Mycologia 4: 14, 200. I912. 
could possess urediniospores partly with one basal pore and partly with three or four equatorial pores. The answer involved the value and application of pore characters in defining species. After special search, ${ }^{8}$ which led to both kinds of urediniospores being found repeatedly in the same sorus, although for the most part they occurred in separate sori, it was concluded that only one species of rust was under consideration, but with morphological as well as physiological races, not well delimited.

It seemed probable, furthermore, that the previously described, one-pored form of Carex rust, known as Uromyces uniporulus Kern, was a race also belonging to the Carex-Ribes species, but it was not possible to test the matter by cultures. In this connection it is interesting to note, and provocative of speculation, that there is no form yet known with three- and four-pored urediniospores belonging under Uromyces in the Carex-Ribes aggregation, to make the parallelism with its Puccinia form complete.

In 1917 , the last year of the culture series, the principle of basing species upon morphological characters, with a greater or less degree of mobility in interpretation, was further illustrated by the case of the Spartina rust, Uromyces Polemonii (Peck) Barth., which it was found could be segregated into four races, ${ }^{\circ}$ separable by small but appreciable differences in morphological characters of both aeciospores and teliospores, and by wholly unrelated aecial hosts, and further reinforced by some differences in habitat and geographical distribution. The correlated Puccinia-form for this common and widely distributed American rust is that of Puccinia Distichlidis, so-called because the type collection was incorrectly labelled as on Distichlis instead of on Spartina. Its range and aecial hosts, so far as known correspond to only one of the four Uromyces races.

At the time the culture work began the subepidermal rusts occurring on wild grasses in America with few exceptions, passed under the name of Puccinia rubigo-vera, along with part of the similar leaf rusts of cereals. No criteria had been found for distinguishing them, not even those which had received special

8 Mycologia 7: 67-69. 1915.

9 Mycologia 9: 309-312. 1917. 
names, and every effort was consequently put forth to make headway into this obscure maze of forms. The first success was in 1902 with a form on Elymus virginicus and aecia on Impatiens, which became Puccinia Impatientis (Schw.) Arth. The work opened up slowly. In 1903 a false move was made in connection with the rust on Bromus, but the year following this rust was shown to have aecia on Clematis virginiana. ${ }^{10}$

In 1907 Puccinia Agropyri E. \& E., as it occurred in Colorado on Agropyron, was found to go to Clematis ligusticifolia, a connection that had been demonstrated by Dietel with European hosts fifteen years before. The following year Puccinia cinerea Arth. on Puccinellia was grown on Ranunculus Cymbalaria, a rust from Koeleria cristata on Mahonia, from Bromus on Thalictrum, from Agropyron on Aquilegia, the last three being described as new species. In 1915 aecia on Hydrophyllum from Utah were made to grow on Agropyron and Elymus, giving rise to uredinia and telia similar to those from the Ranunculaceous aecia, but believed to constitute a distinct species. In I916 another rust on Koeleria cristata was grown on Laciniaria under the name $P$. Liatridis (Ell. \& And.) Bethel. Repeated attempts were made to find the aecial host of the common leaf rust of wheat, $P$. triticina Erikss., but without success, although there were many indications that pointed to a Ranunculaceous host, and especially to Clematis or Anemone. It was thought that a favorable trial on Clematis Flammula would give a measure of success. At any rate it was believed to be one of the numerous races of the subepidermal leaf-rust of grasses, P. Agropyri, with Ranunculaceous hosts for its aecia. ${ }^{11}$

The series were discontinued before the study of the subepidermal forms was completed, but ten of them had been connected with their aecia. The conviction had been growing for some time that some of these ten names represented races of Puccinia Agropyri, rather than independent species, as was stated in discussing the cultures of I9I2. When the manuscript was pre-

10 For a full account and explanation of the mistake of 1903 in supposedly connecting aecia on Dirca with the Bromus rust see Journal of Mycology II: 62-63. 1905 .

11 Mycologia 9: 276. 1917. 


\section{Arthur: Nineteen Years of Culture Work}

pared for the North American Flora P. tomipara, P. Agropyri, $P$. cinerea, $P$. alternans and $P$. obliterata, as well as $P$. triticina, were placed under the one name of $P$. Clematidis (DC.) Lagerh. It is considered a great advance to bring from the limbo of $P$. rubigovera, six distinguishable species, some of them having a considerable number of recognized races, and thereby making it possible to relegate to obscurity some dozen or more names that had previously been encumbering the literature of the rusts.

In a somewhat similar way the American Carex rusts were in utter confusion at the beginning of the cultures. They were quite generally called Puccinia Caricis or P. caricina, no cultures with American material having been made, and diagnostic characters not having been well worked out. Altogether ten species were grown during the culture period to show their full life cycle, and in several of them a number of races was found, including the one-celled Uromyces perigynius. Of course, being able to separate these ten species made it possible to decide upon the identity of other species, which were not actually grown.

A view generally held when the culture work began was that the hosts of an autoecious species, or of each of the two parts of a heteroecious species, would be found to be closely related, often, indeed, to be but a single species, or genus, and certainly always within a single family. Consequently it was felt that when a grass or sedge rust was successfully cultured, the problem about hosts for that species was practically solved. This complacent opinion was quite upset in the case of Puccinia subnitens Diet. on Distichlis spicata, which in 1902 was first grown upon Chenopodium album. In 1904 Rev. J. M. Bates of Nebraska, who had made the field observations and suggestions for this combination, wrote that he had been continuing his observations of this species and believed that it had aecia also on hosts belonging to two other families, which seemed to the writer at the time as most incredible. Tests, however, showed it would flourish on species of Cleome, Lepidium, Sophia and Erysimum, as well as on Chenopodium, compelling the admission that it would grow "with equal vigor upon species belonging to three families of plants," at the time being a "remarkable fact not known for any 
other species of rust." Additional genera in the same families were added from time to time for aecial hosts, until in the cultures of I9I6 the species was grown on Abronia and Polygonum, thus adding two more families. Mr. E. Bethel, of Denver, Colorado, who made the field observations and suggestions for the later additions, has continued the list since the culture series stopped and brought the number up to 76 species, belonging to I9 families, ${ }^{12}$ a truly astonishing showing, and all the more so as no clearly defined races have so far been detected. The only other species of rust with such a remarkably extended series of aecial hosts at all approaching $P$. subnitens Diet., is that of $P$. Isiacae (Thüm.) Wint. from the dry trans-Caspian region of western Asia, as reported by Tranzschel. ${ }^{13}$ This species with telia on Phragmites communis has aecia on 19 species of hosts belonging to 9 families, the aecial families being the same as for $P$. subnitens.

In still another way the conception of species was modified when in 1905 teliospores from Ruellia ciliosa were grown on the same host and also on $R$. strepens. The latter host, with loose, watery tissues, gave rise to aecia fully ten per cent. larger in every way than did the former host with its firm, woody tissues, thus showing that the forms recognized by the Sydows under.Puccinia lateripes B. \& Rav. and P. Ruelliae (B. \& Br.) Lagerh. ${ }^{14}$ represent only a host influence upon one and the same species, this influence being traced not only in the aecia, but also in the other spore-forms.

Thus it will be seen that while the main work of the cultures was effective in completing the life cycles for many species, and in some cases extending and defining the range of hosts, it was at the same time most profoundly modifying the current conception of species among the rusts. Instead of a rigid ideal of a few invariable characters and a limited range of nearly related hosts to be determined by cultures, we have substituted a complex of somewhat variable morphological characters as the basis,

12 Bethel, Phytopathology 9: 193. 1919.

13 Beiträge zur Biologie der Uredineen. Trav. Mus. Bot. Acad. Sci. St. Petersb. 3: 40. 1906; 7: 14. 1909.

14 Sydow, Monographia Uredinearum I: 235. 1902. 
Arthur: Nineteen Years of Culture Work

with a more or less extended range of hosts in part determined by cultures and in part by microscopical similarities in the fungus. A species at the beginning of the work was conceived as a simple and direct succession of individuals of the same appearance, capable of being demonstrated by cultures, but at the close had become a bundle of somewhat mobile characters, often comprising many strains varying physiologically and sometimes morphologically, and to a more or less extent not interchangeable by cultures.

In some other ways than already mentioned the accepted notions regarding rusts were modified. It was found that teliospores among the grass forms were not all necessarily resting spores, and that the non-resting forms presented special problems, whose solution was not far advanced when the work came to $x$ close. Assistance with field observations and material permitted successful cultures to be made in May, I9I I, with the aeciospores from Arabis sown on Trisetum. The Arabis aecia arise from systemic mycelium extending throughout the stem and leaves of the plant. A month later teliospores resulting from this culture, now having become mature, were found to be capable of germination and were sown on seedling rosettes of Arabis. The results of this sowing first definitely showed when the axis of the Arabis began to elongate as growth started the following spring. A culture was similarly carried out in 1903 with Puccinia Eatoniae, using the aecia on Ranunculus abortivus, also a form with diffused mycelium, but a reciprocal culture was not made. These two species of rusts, having a systemic form of aecia, were the only ones of the kind which were brought under culture. They belong to an interesting class physiologically, with systemic aecia, and with teliospores capable of germination upon maturity, which possibly do not retain their viability through the winter, or only to an impaired degree.

The culture work began with the too prevalent idea that all rusts could be expected to conform in general to the well known Puccinia graminis. It closed with the conviction that the rusts are far too diversified in their morphology, their numerous characters, their physiological adaptations, and their range of hosts, 


\section{6}

\section{Mycologia}

to be represented by Puccinia graminis in more than one out of numerous aspects. In this resumé of cultures only a few of the more prominent developments that should help to modify the too rigid and restricted ideas of rust species as commonly held have been brought forward. Yet enough has been said possibly to indicate the value of what has been accomplished and the need of more extended work along similar lines.

Purdue University,

LAFAyETTE, INDiana. 


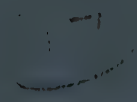

MEMORANDA AND INDEX OF CULTURES

OF UREDINEAE, 1899-1917

J. C. ARTHUR

[Reprinted from Mrcologi,, Vol. XIIT, No. 4 and 5 J July-Sept., 19ax.] 



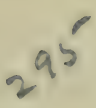

MEMORANDA AND INDEX OF CULTURES OF UREDINEAE, I899-I9I7 


\title{
MEMORANDA AND INDEX OF CULTURES OF UREDINEAE, I899-I9I $7^{1}$
}

\author{
J. C. Arthur
}

The cultures of the rusts, which were conducted under the auspices of the Purdue University Agricultural Experiment Station, and extended over a period of nineteen years, had a small beginning. For the first three years only such time was given to the work as the writer could spare from his duties as head of the Botanical Department of the Station and as Professor of Vegetable Physiology and Pathology in Purdue University. In most of the following years an assistant was especially employed during two or so months each spring, who had entire charge of the testing of spore viability, sowing of the spores, and care of the inoculated plants, the chief part of the culture work being done during May and June. The position was held by fourteen individuals, selected with the needs of the work especially in view, and ranging from a junior high school student to university instructors, who without exception showed superior ability in conducting the work. Financial support was provided by a grant from the Botanical Society of America in 1903, I906 and 1907, and by coöperation with the Bureau of Plant Industry of the U. S. Department of Agriculture in 1904 and 1905. In the other years it was supplied by the Purdue University Agricultural Experiment Station, and from 1908 onward the work was made a part of the rust project under the Adams fund.

During the progress of the work the writer, usually accompanied by an associate, made many shorter or longer excursions for securing data and material. These field observations were directed toward detecting the juxtaposition of spore-forms that might be supposed to have genetic connection, as well as toward securing suitable culture material. The fruitfulness of this method is apparent from the fact that during the extended study

1 Contribution from the Botanical Department of the Purdue University Agricultural Experiment Station. 


\section{Artilur: Cultures of Ukedineae, i $899-191798$}

of heteroecious species only three times was a discovery of alternate hosts effected that was not the outcome of a previous field observation. In two of these cases, that of Uromyces acumina:us (more properly U. Steironematis, see page $76,{ }^{*}$ Jour. Myc. 12: 25), and Puccinia Ceanothi (see page 196,* Mycologia 4:27) sowings were made on all available hosts in the greenhouse, recorded as bearing aecia, and in the case of $P$. fraxinata $(P$. peridermiospora, see page $8,{ }^{*}$ Bot. Gazette 29: 275), a morphological similar:ty was detected between aesciospores and urediniospores, leading to successful cultures.

Beginning with the immediate vicinity of Lafayette, Indiana, the range of observations was extended to various parts of the state, and in the ninth year of the work, 1907, to other states. This year a trip was made to the foothills of Colorado, which was repeated in 1908, I9II and 1916, observations being made from Boulder to Trinidad, and once westward to Ouray and Durango. Between 1908 and 1916 trips were made northward to Wisconsin and Michigan, eastward to Maine and Pennsylvania, to South Carolina, Alabama and Mississippi in the south, and to Texas, New Mexico and Arizona in the southwest. So far as possible places were selected where there were local collectors, or where records showed that species requiring investigation had at some time been secured. The chief collecting grounds of Ellis in New Jersey, Ravenel in North and South Carolina, Atkinson and Underwood in Alabama, and Kellerman in Kansas were visited, and the collecting grounds of Schweinitz at Salem, North Carolina,'and Bethlehem, Pennsylvania, would have been visited, if opportunity had favored. In this way many obscure names in the literature were connected with living material on which fresh and more extended studies, often including cultures, could be carried out. By this method the attention given to the genus Gymnosporangium was made to expand our limited knowledge of a few species into an understanding of the life history of some two dozen species and of their alternate hosts. The effectiveness of the work with Gymnosporangium was greatly enhanced by the special interest in it taken by my asso-

\footnotetext{
* For explanaticn of these page numbers see p. 246 at beginning of the index.
} 
ciate, Dr. F. D. Kern, who for ten years took part in the culture work. The grass and sedge rusts were, however, the ones that received the most extended and prolonged attention.

To carry on the work more than 2140 collections with resting spores were available, together with over 250 collections with spores not requiring a resting period. Tests of all of these, and of some many times repeated, showed that not all were viable, at least at the time tested, and therefore not serviceable. This material was provided in part by those directly connected with the work, and to a considerable extent by more than 85 botanical correspondents, many of whom contributed most generously in material and field observations year after year. Altogether about 3750 sowings, that is, attempts at cultures were made, of which about one in seven resulted in successful infection of the host. These tests were almost wholly made in a greenhouse, although a few were conducted in the open field when small plants suitable for placing in pots were not available.

It is difficult to say just how many species have been grown through some part of their life cycle during the nineteen-year period, owing to the constant shifting of accepted names as knowledge regarding them accumulated. Probably the list includes about one hundred species, as they are now rated, or nearly twice as many as they would at first have been listed, and of this number about eight were heteroecious to one autoecious. Of the heteroecious species some twenty were verifications of combinations previously established, mostly by European investigators, while about sixty-five provided alternate hosts for species whose life cycle was before unknown, most of these being grass and sedge forms not known outside of North America.

When viewing the present location of the New York Botanical Garden many years ago, it then being a rolling meadow without buildings of any kind, my companion, Professor L. M. Underwood, remarked that some day I might be called upon to supply the rust portion for the projected North American Flora, and added that if I did so he had no doubt that I would greatly reduce the number of species. The culture studies have enabled me to do this, but not quite in the way Professor Underwood 
Arthur: Cultures of Uredineae, i8go-igi 300

and others at that time had in mind. In many cases the first results have been to increase the number of species. Thus Puccinia alternans and $P$. obliterata were described as new species as result of cultures, but as the studies proceeded were reduced to synonyms of the long recognized $P$. Agropyri, together with Aecidium Aquilegiae, A. Clematidis, Puccinia tomipara, P. Paniculariae, and some others. But on the whole, as the cultures have largely dealt with heteroecious species, there has been a reduction in names as the alternate forms were brought together, and sometimes by the recognition as races of forms that were once thought distinct species.

The nomenclature of the reports has been made as conservative as possible, in order to give them reasonable uniformity. The new generic names proposed by the writer in 1906 at the Vienna Congress scarcely find an echo in them, while on the other hand the terminology for spore-forms, brought out in 1905, was put into use in the second report following, and proved highly serviceable.

In the various reports of the cultures, and as a result of them, the following thirteen specific names were transferred to other genera: Aecidium magnatum Arth. and $A$. Silphii Sydow to Uromyces, Aecidium Ceanothi Peck, A. Impatientis Schw., A. Jamesianum Peck, A. macrosporum Peck, A. monoicum Peck, $A$. Pammelii Trel., A. Phrymae Halst., A. pustulata Curt., A. Sambuci Schw. to Puccinia, and Puccinia tumidipes Peck and $P$. Vernoniae Berk. \& Curt. to Bullaria.

Also as the result of the cultures the following sixteen species were described as new: Gymnosporangium corniculans Kern, G. exterum Arth. \& Kern, G. trachysorum Kern, and on the authority of the writer Puccinia albiperidia, $P$. alternans, $P$. CaricisAsteris, $P$. Caricis-Erigerontis, $P$. Caricis-Solidaginis, $P$. Eatoniae, $P$. Koeleriae, $P$. obliterata, $P$. patruelis, $P$. universalis, Uromyces effusus, $U$. Solidagini-Caricis, and $U$. Steironematis, but as the result of further studies most of these were subsequently buried in synonymy. 


\section{Corrections}

In making corrections the consecutive page numbers used are those explained below at the beginning of the index, while the original pages are given in parentheses. A few of the corrections are typographical errors, or slips of the pen, but many are necessitated by information variously acquired after the reports were written and printed. Evident and inconsequential errors are not included. To save space the following abbreviations are used in the parentheses: B.G. for Botanical Gazette, J.M. for Journal of Mycology, and My. for Mycologia, and are followed by the original volume and page number.

Pages 5, 9 (B.G. 29: 272, 276), under 7 and 3 respectively, for "Americana Lagh." and "Americana," read Andropogonis Schw. and Andropogonis, respectively, and for "Andropogi Schw." and "Andropogi," read Ellisiana Thüm. and Ellisiana, respectively. $\& \mathrm{~K}$.

Pages 7, 9, 22, 28 (B.G. $29: 274,276 ; 35: 16,22$ ), for “K. \& S.," read E.

Pages 8, 31, 51, 60,67,75,76,77,78, 83, 103, 106, 114, 127, 146, 156, 160, 164,174 (B.G. $29: 275$; J.M. $10: 9 ; 11: 57,66 ; 12: 16,24,25,26,27 ; 13$ : 192; 14: 14, 17, 25; My. I: 236, 255;2: 221, 225, 229, 239), for the species of Spartina, given as "cynosuroides" or "cynosuroides Willd.," read Michauxiana or Michauxiana Hitchc. The two species of grass were for a time confused and one name used for both.

Pages I1, 65, 77, 86, 94 (J.M. 8: $52 ; 12: 14,26 ; 13$ : 196, 204), for a species of Carex, for "tetanica" and "tetanica Schk.," read blanda and blanda Dewey, respectively.

Pages $17,45,49,50,60$ (B.G. 35: II; J.M. II: $5 x, 55,56,66$ ), for the species of Lepidium, given as "apetalum" and "apetalum Willd.," read densiflorum and densiflorum Schrad., respectively.

Page 26 (B.G. $35: 20$ ), the Aecidium mentioned under 5. P. Amphigena was subsequently found not to be $A$. Smilacis Schw.

Pages 41, 42 (J.M. 10: 19, 20). The supposed infection in 1903 of Bromus ciliatus by the application of aeciospores from Dirca palustris was the most serious error that occurred in the nineteen years of culture work. The grass used for the culture was undoubtedly infected before the sowing was made, as explained on pages 56 and 57 of the report following. The combination of aecia and telia under the name "Puccinia hydnoidea," was unwarranted. The Aecidium hydnoideum was under close observation during the whole culture period, and there were a score of attempts to find the alternate host, but even to the present writing no progress has been made.

Pages 49, 50 (J M. II : 55, 56), under no. 4, for the species of Sophia from Nebraska, given as "incisa (Engelm.) Greene," read intermedia Rydb.

Pages 49, 60, 68, 77 (J.M. II: 55, 66; 12: 17, 26), for the species of Sophia from Indiana used in the cultures, given as "incisa" and "incisa (Engelm.) Greene," read brachycarpa and brachycarpa Rydb. 


\section{Artilur: Cultures of Uredineae, i890-1917 3942}

Pages 51, 60, 67, 77, 103, $114,127,146,160,174$, (J.M. 1x: 57,$66 ; 12: 16$, $26 ; 14: 14,25 ;$ My. 1: 236, 255; 2: 225, 239), after Puccinia fraxinata, for "Schw.," read Link.

Page 62, first line of reprint, for " 1 ," read 12.

Page 64 (J.M. 12: 13 ), under no. 6, for "Schw.," read Desmaz.

Pages 66, 77 (J.M. 12: 15, 26), under no. 7, for specific name "aquatilis" and "aquatilis Wahl.," read nebraskensis and nebraskensis Dewey. On page 66 the comparison of the large, thick-walled urediniospores (common on this host. the form being known as Puccinia Garrettii Arth.) to the amphispores of $P$. Caricis-stictae was an error. It may be pointed out here that the same mistake regarding name of the host also occurs in Sydow, Uredineen 2115 , Barth. Fungi Columb. 2351 and 38.38. Carex nebraskensis is a very common sedge about Denver and Boulder, Colo., while C. aquatilis is rare or possibly absent.

Pages 85, 92, 94 (J.M. 13: 195, 202, 204), under Lactuca, for "virosa," read scariola.

Pages 93, 95, 107, 114, 130, 146, 195, 201 (J.M. 13: 203, 205; 14: 18, 25 : My. x: 239, 255; 4: 26, 32), under Gymnosporangium, for "Nelsoni Arth.," read juvenescens $\mathrm{Kern}$, and also delete the last sentence under no. I9 on page 107 (J.M. 14: 18). Gymnosporangium Nelsoni and G. juvenescens were for a time confused. Both produce aecia on Amelanchier and Sorbus, but the former gives rise to woody galls, often very small, while the latter is foliicolous.

Page 96, first line of the reprint for "1907," read 1908.

Pages 100, 180 (J.M. 14: 11; My. 4: ri), under Puccinia, for "montanensis Ellis," read Agropyri Ellis \& Ev., as pointed out on page 263 (My. 8: 139).

Pages 109, 115 (J.M. 14: 20, 26), under no. 2, for "Cryptandri Ellis \& Barth.," read substerilis Ellis \& Ev., and for "Sporobolus cryptandrus (Torr.) A. Gray," read Stipa viridula Trin.

Pages II2, II5 (J.M. $\left.x_{4}: 23,26\right)$, under no. 6, for "mutabilis Ellis \& Gall.," read Blasdalei Diet. \& Holw., for "reticulatum Fraser," read Brandegei S. Wats., and for "recurvatum Rydb.," read cernuum Roth.

Page 123 (My. I : 232), under no. 11, for "Aster arenarioides D. C. Eaton," read Erigeron arenarioides A. Gray.

Pages 129, 130, 146 (My. I : 238, 239, 255), the small form of Gymnosporangium on Juniperus virginiana. which gave rise to pycnia and aecia on Crataegus punctata, should have been referred to G. floriforme Thaxter.

Page 133 (My. 1: 242), delete the entire paragraph beginning "The aecia of this species," etc., except the first sentence.

Page 147 (My. I: 256), under no. 8, for "glomerata," read mexicana (L.).

Page 173 (My. 2: 238), under no. I, change the reading thus: Teliospores on Carex lanuginesa Michx., sown on Onagra biennis (L.) Scop., and on C. trichocarpa Muhl. sown on Gaura biennis L.

Pages 178,180 (My. 4:9, II), 19th and 6 th line from bottom respectively, for "Douglasii," read spartioides.

Pages $180,189,197,200,231$ (My. 4: $11,20,28,31 ; 7: 72$ ), as a species of Senecio, for "lugens" or "lugens A. Gray." read spartioides or spartioides T. \& G., respectively. 


\section{${ }_{236}^{3} 08$}

\section{Mrcologia}

Pages 197, 202 (My. 4: 28, 33), under no. 2, the material in hand from Isle au Haut, Me., was Puc. quadriporula ( $P$. Grossulariae), but the results of infection were obtained from stray spores of Uromyces perigynius, as explained at page 235 (My. 7: 76) in the report of cultures for 1912.

Pages 256, 265 (My. 8: 132, 14I), under no. 4, for "Agropyri E. \& Ev. (P. alternans Arth)," read Cockerelliana Bethel. This distinctive species was not recognized, and had not been named until long after the cultures were made.

Pages 257, 265, (My. 8: 133, 14I), under no. 5, for "Anchusa officinalis," read Lycopsis arvensis.

Pages 26r, 263, 265 (My. 8: 137, 139, 141), under no. 3, for "montanensis Ellis" and "montanensis," read apocrypta Ellis \& Tracy and apocrypta, respectively. On page 262 three species are confused. Puccinia apocrypta is not a synonym of $P$. Agropyri. The characters given for $P$. apocrypta are those of the true $P$. montanensis, for which the type is the collection cited. Pages 274, 275 (My. 9: 302, 303), under no. 2, for "B. \& Co" read Schw.

\section{SUMMARY OF CULTURES}

In order to give a clearer perspective of the work, and to make the data more readily available, the following tabulation is given of the heteroecious species that were successfully grown on alternate hosts. Autoecious species, and heteroecious species grown from urediniospores or amphispores only, have not been included. The years are those in which successful cultures were carried out. Only such synonymy is given as will account for the names used at different times in the reports. The page numbers are those explained below at the beginning of the index. Pages in broad faced type indicate the host from which spores were taken for culture, while pages in common type indicate the host on which the culture was successfully established. 
ARthur: CUltures of URedineae, I899-19I7

\begin{tabular}{|c|c|c|c|}
\hline Year & Rust & Telial host & Aecial host \\
\hline $\begin{array}{l}1904 \\
1905\end{array}$ & Puc. Sorghi Schw. & Lea Mays 59, 68 & $\begin{array}{l}\text { Oxalis corniculala }(O \text {. } \\
\text { cymosa) } 59.68\end{array}$ \\
\hline 1909 & $\begin{array}{l}\text { Puc. Ceunothi (E. \& K.) } \\
\text { Arth. }\end{array}$ & Andropogon Hallii 168 & $\begin{array}{l}\text { Ceunolhus umericuna } \\
\text { I68 }\end{array}$ \\
\hline 1912 & Puc. Ellisiane Thitm. & Andropogon sp. 230 & $\begin{array}{l}\text { Viola cucullatis } 230 \\
V . \text { Nuthellii } 230\end{array}$ \\
\hline $\begin{array}{l}1899 \\
1903 \\
1906 \\
1910\end{array}$ & $\begin{array}{l}\text { Puc. Andropogunis } \\
\text { Schw. (P. umericuna } \\
\text { Lagerh.) }\end{array}$ & $\begin{array}{l}\text { 4. dropogon scopurius } \\
\text { 5.6, 33, 87, 186 } \\
\text { A. virginicus } 186\end{array}$ & $\begin{array}{l}\text { Pentstemon hirsulus }(P \text {. } \\
\text { pubescens) } 5,6,33,87 . \\
\quad \begin{array}{l}86 \\
P \text {. alpinus } 186\end{array}\end{array}$ \\
\hline $\begin{array}{l}1903 \\
1905 \\
1910\end{array}$ & $\begin{array}{l}\text { Puc. pustuluta (Curt.) } \\
\text { Arth. }\end{array}$ & $\begin{array}{l}\text { A ndropogon furcalus } 39 . \\
67,186 \\
\text { A. scoparius } 39\end{array}$ & $\begin{array}{l}\text { Comandra umbellala } 39 \text {. } \\
67,186\end{array}$ \\
\hline $\begin{array}{l}1904 \\
1905 \\
x 907\end{array}$ & $\begin{array}{l}\text { Puc. Panmelii (Trel.) } \\
\text { Arth. (P. Panici } \\
\text { Diet.) }\end{array}$ & $\begin{array}{c}\text { Punicum virgalum } \\
50,67, \mathbf{1 0 5}\end{array}$ & $\begin{array}{l}\text { Euphorbia corollata } 50 \text {, } \\
\quad 67 \\
\text { E. marginata ro5 }\end{array}$ \\
\hline $\begin{array}{l}1901 \\
1904 \\
1905 \\
1906 \\
1907 \\
1909 \\
1910 \\
1916\end{array}$ & $\begin{array}{l}\text { Puc. poculiformis } \\
\text { (Jacq.) Wettst. (P. } \\
\text { graminis Pers.) }\end{array}$ & 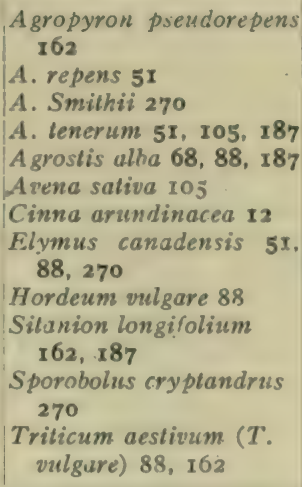 & $\begin{array}{l}\text { Berberis vulguris I } 2,51 \text {, } \\
68,88,105,162,187 \\
270\end{array}$ \\
\hline I9I7 & $\begin{array}{l}\text { Puc. Majanthae } \\
\text { (Schum.) Arth. }\end{array}$ & $\begin{array}{l}\text { Phalaris arundinacea } \\
\qquad \mathbf{2 7} 8\end{array}$ & Iris versicoler 278 \\
\hline $\begin{array}{l}1904 \\
\text { I9I0 } \\
\text { IgI } 2\end{array}$ & Puc. Stipae Arth. & $\begin{array}{l}\text { Koeleria cristata } \times 89 \\
\text { Stipa comata } 231 \\
\text { S. sparted } 58,188\end{array}$ & $\begin{array}{l}\text { Aster ericoides } 58, \text { I } 88 \\
\text { A. multiflorus } 58,188 \\
\text { A. Novae-Angliae } 58, \\
\text { I } 88 \\
\text { Grindelia squarrosa } 188 \\
\text { Gutierresia Surothrae } \\
23 \mathrm{I} \\
\text { Senecio spartioides } 189 . \\
23 \mathrm{I} \\
\text { Solidago canudensis } 188\end{array}$ \\
\hline
\end{tabular}




\section{Mycologia}

\begin{tabular}{|c|c|c|c|}
\hline Year & Rust & Telial host & Aecial host \\
\hline I9I 7 & Puc. Sporoboli Arth. & $\begin{array}{l}\text { Sporobolus heterolepis } \\
280\end{array}$ & $\begin{array}{l}\text { Allium cernuum } 280 \\
\text { A. Nuttallii } 280 \\
\text { Lilium umbellatum } 280\end{array}$ \\
\hline $\begin{array}{l}1899 \\
1902 \\
1904 \\
1905\end{array}$ & $\begin{array}{l}\text { Pui. verbenicola (E. \& } \\
\text { K.) Arth. (P. Vilfae } \\
\text { Arth. \& Holw.) }\end{array}$ & $\begin{array}{l}\text { Sporobolus longifolius } 7 \text {, } \\
\quad 22,50,67\end{array}$ & $\left\{\begin{array}{l}\text { Verbena stricta } 7,22 \\
V . \text { urticifolia } 22,50,67\end{array}\right.$ \\
\hline $\begin{array}{l}1902 \\
1904 \\
1905 \\
1906 \\
1907 \\
1908 \\
1909 \\
1910 \\
1911 \\
1915 \\
1916 \\
1917\end{array}$ & Puc. subnilens Diet. & $\begin{array}{l}\text { Distichlis spicatu } 25,49 \\
68,87,104,126,160 \\
188,208,259,273,278\end{array}$ & 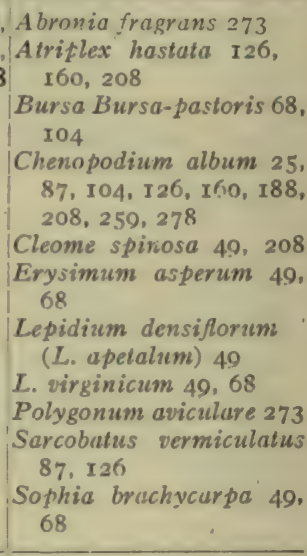 \\
\hline $\begin{array}{l}\text { I908 } \\
\text { 1909 } \\
\text { I910 } \\
\text { I9I4 } \\
\text { I9I6 }\end{array}$ & $\begin{array}{l}\text { Puc. Muhlenbergiae } \\
\text { Arth. \& Holw. (P. } \\
\text { tostu Arth.) }\end{array}$ & $\begin{array}{l}\text { Muhlenbergia gracillima } \\
27 \mathbf{x} \\
M . \text { mexicana } \mathbf{1} 42 \\
M \text {. racemosa }(M \text {. glom- } \\
\text { erata) I6r, } 187 \\
\text { Schedonnardus panicu- } \\
\text { lalus } 272 \\
\text { Sporobolus asperifolius } \\
240,241\end{array}$ & $\begin{array}{l}\text { Cullirhoe involucrala } \\
\text { I42, I6I, I87 } \\
\text { Malvastrum coccineum } \\
271,272 \\
\text { Sphaeralcea digitata } 241 \\
\text { S. incana } 240 \\
\text { S. lobata } 241\end{array}$ \\
\hline $\begin{array}{l}1902 \\
1903 \\
1905 \\
1907 \\
1909 \\
1910\end{array}$ & Puc. amphigenc Diet. & $\begin{array}{l}\text { Calumovilfa longifolia } \\
26,33,67,104,160, \\
x 87\end{array}$ & $\begin{array}{l}\text { Smilax herbucea } 26 \\
\text { S. hispidu 26, 33, } 67 \text {, } \\
\text { I04, I60, I87 }\end{array}$ \\
\hline $\begin{array}{l}\text { IgII } \\
\text { IgI } 2\end{array}$ & $\begin{array}{l}\text { Puc. monoica (Peck) } \\
\text { Arth. }\end{array}$ & \begin{tabular}{|l|} 
Koeleria cristata 234 \\
Trisetum majus $2 \mathrm{I} 3$ \\
T. subspicatum $2 \mathrm{I3}, 234$
\end{tabular} & Arabis sp. 213, 234 \\
\hline $\begin{array}{l}\text { I904 } \\
\text { I9I0 } \\
\text { I9I6 }\end{array}$ & $\begin{array}{l}\text { Puc. Rhamni (Pers.) } \\
\text { Wettst. (P. coronata } \\
\text { Corda) }\end{array}$ & $\begin{array}{l}\text { A grostis sp. } 27 \mathrm{x} \\
\text { A vena sativa } 52 \\
\text { Calamagrostis canaden- } \\
\quad \text { sis } 187\end{array}$ & $\begin{array}{l}\text { Rhamnus alnifolia } 187 \\
R \text {. caroliniana } \mathbf{5 2} \\
R \text {. cathartica } \mathbf{5 2} \\
R \text {. lanceolata } \mathbf{5 2} \\
R \text {. Purshiana } 27 \mathrm{I}\end{array}$ \\
\hline
\end{tabular}


Arthur: Cultures of Uredineae, i899-igi 306

\begin{tabular}{|c|c|c|c|}
\hline Year & Rust & Telial host & Aecial host \\
\hline $\begin{array}{l}1899 \\
1004 \\
1905 \\
1007 \\
1908 \\
1909\end{array}$ & $\begin{array}{l}\text { Puc. fraxinala (Link) } \\
\text { Arth. ( } P \text {. peridermi- } \\
\text { ospora Arth.) }\end{array}$ & $\begin{array}{l}\text { Spartina Michauxiuna } \\
\text { (not S. cynosuroides) } \\
8,51,67,103,160 \\
\text { S. polystachya } 127 \\
\text { S. stricta } 127\end{array}$ & $\begin{array}{l}\text { Fraxinus lanceoluta ( } F \text {. } \\
\text { viridis) } 8,51,67,103 \text {. } \\
127,160\end{array}$ \\
\hline $\begin{array}{l}1915 \\
1916\end{array}$ & $\begin{array}{l}\text { Puc. Distichlidis E. \& E. } \\
\text { (P. Kelseyi Syd. }\end{array}$ & $\begin{array}{l}\text { Spartinu Michauxiana } \\
26 \mathrm{I}, 27 \mathrm{I}\end{array}$ & $\begin{array}{l}\text { Stcironema ciliutum } 26 \mathrm{I} \text {, } \\
27 \mathrm{I}\end{array}$ \\
\hline $\begin{array}{l}1905 \\
1908 \\
1910 \\
1915\end{array}$ & Puc. Seymouriana Arth. & $\begin{array}{l}\text { Spartina cynosuroides } \\
259 \\
\text { S. Michunxiana (not } S \text {. } \\
\text { cynosuroides) } 75,127 \\
188,258\end{array}$ & $\begin{array}{l}\text { A pocynum cannubinum } \\
25^{8} \\
\text { Asclepias syriaca } 259 \\
\text { Cephalanthus occident- } \\
\text { ulis } 75,127,188\end{array}$ \\
\hline $\begin{array}{l}1902 \\
1910\end{array}$ & $\begin{array}{l}\text { Puc. Jamesiane (Pcck) } \\
\text { Arth. (P. Bartholo- } \\
\text { muei Diet.) }\end{array}$ & $\begin{array}{c}\text { Boutelou curtipendula } \\
\text { (Atheropogon curti- } \\
\text { pendulus) 24, } 188\end{array}$ & $\begin{array}{l}\text { Asclepias incarnata } 24 \\
\text { A. syriaca } 24,188\end{array}$ \\
\hline $\begin{array}{l}1899 \\
1907 \\
1909 \\
1911\end{array}$ & $\begin{array}{l}\text { Puc. Phragmitis } \\
\text { (Schum.) Körn. }\end{array}$ & $\begin{array}{l}\text { Phragmites communis } \\
\text { (P. Phragmites) } 2 \text {, } \\
\text { 104, 160, } 208\end{array}$ & $\begin{array}{l}\text { Rumex crispus 2, } 104, \\
\text { 160, 208 } \\
\text { R. obiusifolius 2 }\end{array}$ \\
\hline $\begin{array}{l}1902 \\
1907\end{array}$ & Puc. simillima Arth. & $\begin{array}{l}\text { Phragmites communis } \\
\text { (P. Phragmites) 26, } \\
\text { x04 }\end{array}$ & $\begin{array}{l}\text { Anemone canadensis } 26 \text {, } \\
\text { I04 }\end{array}$ \\
\hline $\begin{array}{l}1899 \\
1902 \\
1904 \\
1915\end{array}$ & Puc. Windsoriae Scluw. & $\begin{array}{l}\text { Tridens favus (Triodia } \\
\text { cuprea, Tricuspis ses- } \\
\text { lerioides) } 6,22,50 . \\
260\end{array}$ & Ptelea trifoliata 6, 22, 50 \\
\hline 1903 & Puc. Eatoniae Arth. & $\begin{array}{l}\text { Ealonia pennsylvanica } \\
\text { 4' }\end{array}$ & Ranunculus abortivus 40 \\
\hline Iด08 & Puc. Koeleriae Arth. & Koeleria cristala ${ }_{13} 8$ & $\begin{array}{l}\text { Mahonia Aquifolium } \\
\text { I38 }\end{array}$ \\
\hline I9I6 & $\begin{array}{l}\text { Puc. Liatridis (E. \& A.) } \\
\text { Bethel }\end{array}$ & Koeleria cristata 273 & Laciniaria punctata 273 \\
\hline I9I0 & $\begin{array}{l}\text { Puc. Crandallii Pam. \& } \\
\text { Hume }\end{array}$ & Festuca confinis 196 & $\begin{array}{l}\text { Symphoricarpos race- } \\
\text { mosus } 196\end{array}$ \\
\hline r9I5 & $\begin{array}{l}\text { Puc. Cockerelliana } \\
\text { Bethel }\end{array}$ & Festuca Thurberi 256 & Thalictrum dioicum 256 \\
\hline $\begin{array}{l}\text { I908 } \\
\text { I9 } 5\end{array}$ & $\begin{array}{l}\text { Puc. Asperifolii (Pers.) } \\
\text { Wettst. }\end{array}$ & Secale cereale $\times 28,257$ & $\begin{array}{l}\text { Lycopsis arvensis } 128 \text {, } \\
257\end{array}$ \\
\hline 1915 & $\begin{array}{l}\text { Puc. apocrypta Ellig \& } \\
\text { Tracy }\end{array}$ & $\begin{array}{l}\text { A gropyron tenerum } 26_{2} \\
\text { Elymus virginicus } 262\end{array}$ & $\begin{array}{l}\text { Hydrophyllum capi- } \\
\text { latum } 262\end{array}$ \\
\hline
\end{tabular}




\begin{tabular}{|c|c|c|c|}
\hline Year & Rust & Telial host & Aecial host \\
\hline $\begin{array}{l}1904 \\
1906 \\
1907 \\
1908 \\
1909 \\
1911 \\
1912 \\
1914\end{array}$ & $\begin{array}{l}\text { Puc. Clematidis (I)C.) } \\
\text { Lagerh. (P. Agropyri } \\
\text { E. \&. E., P. Lomipara } \\
\text { Trel., P. cinerea Arth. } \\
\text { P. alternans Arth., P. } \\
\text { obliterate Arth.) }\end{array}$ & $\begin{array}{l}\text { A gropyron biforum } \mathbf{1} 40 \\
\text { A. pseudorepens } 105 \\
\text { A. Smithii } \mathbf{2 3 2} \\
\text { A. sp. } \mathbf{6} 6 \mathbf{1} \\
\text { Bromus purgans } \mathbf{8 7}, \mathbf{1 2 7} \\
\text { B. ciliatus } \mathbf{5 6} \\
\text { B. Porteri } \mathbf{1} 39 \\
\text { Elymus canadensis } \mathbf{2 3 2} \\
\text { E. virginicus } \mathbf{2 4 2} \\
\text { Puccinellia airoides } \mathbf{1 3 7} \\
208\end{array}$ & $\begin{array}{l}\text { Anemone cylindrica } 232 \\
\text { Aquilegia canadensis } \\
\text { I40, I6I } \\
\text { Clematis Drummondii } \\
242 \\
\text { C. ligusticifolia } 232 \\
\text { C. virginiana } 55,87,105 \text {, } \\
\text { I27 } \\
\text { Oxygraphis Cymbalaria } \\
\text { (Ranunculus Cymba- } \\
\text { laria) I37, } 208 \\
\text { Thalictrum alpinum } 161 \\
\text { T. dioicum I39 } \\
\text { Viorna Scotti I05 }\end{array}$ \\
\hline $\begin{array}{l}1902 \\
1903 \\
1904 \\
1909\end{array}$ & $\begin{array}{l}\text { Puc. Imputientis } \\
\text { (Schw.) Arth. }\end{array}$ & $\begin{array}{l}\text { Elymus cunadensis } 152 \\
\text { E. striulus } \mathbf{1 6 1}, \mathbf{1 6 2} \\
\text { E. virginicus } 25, \mathbf{3 3}, \mathbf{5 1} \\
\mathbf{1 6 2}\end{array}$ & $\begin{array}{c}\text { Imputiens aurea } 25,33, \\
51,16 \mathrm{r}, 162\end{array}$ \\
\hline 1907 & Puc. obtecta Peck & Scirpus americunus Iog & $\begin{array}{l}\text { Bidens connatu I09 } \\
\text { B. frondosa Iog }\end{array}$ \\
\hline $\begin{array}{l}1899 \\
1901 \\
1904 \\
1906 \\
1907 \\
1908 \\
1910 \\
1911 \\
1912\end{array}$ & Puc. angustuta Peck & $\begin{array}{c}\text { Scirpus atrovirens } 6,12, \\
52,86,103,186,230 \\
\text { S. cyperinus } 125,208\end{array}$ & $\begin{array}{l}\text { Lycopus americunus 6, } \\
\text { 12, } 52,86,103,186, \\
208,230 \\
\text { I. uniflorus (L. com- } \\
\text { munis) I25 }\end{array}$ \\
\hline I9I 5 & Puc. Eriophori Thtim. & $\begin{array}{l}\text { Eriophorum viridicuri- } \\
\quad \text { nalum } 255\end{array}$ & Senecio aureus $\mathbf{2 5 5}$ \\
\hline 1905 & $\begin{array}{l}\text { Puc. cancliculata } \\
\text { (Schw.) Lagerh. }\end{array}$ & Cyperus esculentus 74 & ${ }_{74}^{\text {Xanthium "canadense" }}$ \\
\hline $\begin{array}{l}1905 \\
1906 \\
1908\end{array}$ & Puc. Eleocharidis Arth. & $\begin{array}{l}\text { Eleocharis palustris } \\
\quad 74,87,124\end{array}$ & $\begin{array}{c}\text { Eupatorium perfoliutum } \\
74,87,124\end{array}$ \\
\hline 1908 & $\begin{array}{l}\text { Puc. macrospora (Peck) } \\
\text { Arth. }\end{array}$ & Carex comosa $\mathrm{I}_{34}$ & Smilax hispida I34 \\
\hline $\begin{array}{l}\text { I901 } \\
1903 \\
1904 \\
1905 \\
1906 \\
\text { I907 } \\
\text { I910 } \\
\text { I912 } \\
\text { I913 } \\
\text { I915 }\end{array}$ & $\begin{array}{l}\text { Puc. Grossulariae } \\
\text { (Pers.) Lagerh. ( } P \text {. } \\
\text { albiperidia Arth.) }\end{array}$ & $\begin{array}{l}\text { Carex urctata } 226,254 \\
\text { C. blanda } 65,86 \\
\text { C. crinita } 53,86,102, \\
226 \\
\text { C. Rexuosa (C. tenuis) } \\
\text { I82, 226, } 254 \\
\text { C. gracillima } 33,53 \\
\text { C. pallescens } 182 \\
\text { C. pubescens } 12,225 \\
\text { C. squarrosu } 86 \\
\text { C. sp. } 237\end{array}$ & $\begin{array}{l}\text { Ribes aureum } 53 \\
R . \text { Cynosbuti } 12,33,53, \\
86,102,182,225,226, \\
237,254 \\
R . \text { gracile } 65,86 \\
R . \text { rotundifolium } 53,86 \\
R . \text { uva-crispa } 33,53\end{array}$ \\
\hline
\end{tabular}


Arthur: Cultures of Uredineae, $1899-1917241$

\begin{tabular}{|c|c|c|c|}
\hline Year & Rust & Telial host & Aecial host \\
\hline $\begin{array}{l}1901 \\
1902 \\
1905 \\
1907 \\
1909 \\
1910\end{array}$ & $\begin{array}{l}\text { Puc. Caricis (Schum.) } \\
\text { Schroet. }\end{array}$ & $\begin{array}{l}\text { Carex aristala } 158,186 \\
\text { C. nebraskensis } 66 \\
\text { C. riparia } 22,103 \\
\text { C. stipata } 66,103 \\
\text { C. stricta } 11,22,186\end{array}$ & $\begin{array}{l}\text { Urlica gracilis } 11,22,66 \text {, } \\
\quad 103, \times 58,186\end{array}$ \\
\hline I9 I 4 & Puc. minutissimu Arth. & Carex filiformis 245 & Decodon verticillatus 245 \\
\hline $\begin{array}{l}1907 \\
1909 \\
1910 \\
1916\end{array}$ & Puc. universalis Arth. & $\begin{array}{l}\text { Curex filifolia } 270 \\
\text { C. stenoplyyll a } 110.159 \text {, } \\
185\end{array}$ & $\begin{array}{l}\text { Artemisia drucuncu- } \\
\text { loides I10, I59, } 185 \\
\text { A. gnaphalodes } 270\end{array}$ \\
\hline 1907 & $\begin{array}{l}\text { Puc. Phrymae (Ilalst.) } \\
\text { Arth. }\end{array}$ & Carex longirostris $\mathbf{I X I}$ & Phryma leptostuchyu III \\
\hline $\begin{array}{l}1901 \\
1902 \\
1904 \\
1905 \\
1907 \\
1908 \\
1909 \\
1910 \\
1912 \\
1913 \\
1914 \\
1915\end{array}$ & $\begin{array}{l}\text { Puc. Asterum (Schw.) } \\
\text { Kern (P. extensicola } \\
\text { Plow., P. Caricis-As- } \\
\text { teris Arth., P. Caricis- } \\
\text { Erigerontis Arth., P. } \\
\text { Caricis-Solidaginis } \\
\text { Arth., P. Dulichii } \\
\text { Syd.) } \\
\end{array}$ & $\begin{array}{l}\text { Carex festiva } 159,185 \\
\text { C. festucacea } 13,22,52 \\
\text { C. foenea } 13,14,21 \\
\text { C. Jamesii } 27 \\
\text { C. retrorsa } 228 \\
\text { C. rosea } 102 \\
\text { C. scoparia } 184,228,229 \\
\text { C. spurganioides } 66,124 \\
\text { C. stipata } 27 \\
\text { C. sp. } 102 \\
\text { C. vulpinoidea 238, } 240 \\
\text { Dulichium arundi- } \\
\text { naceum } 240,254 \\
\end{array}$ & 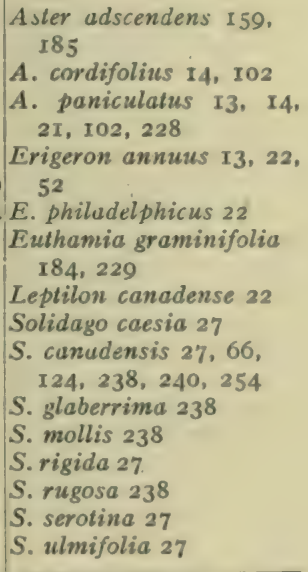 \\
\hline $\begin{array}{l}1902 \\
1904 \\
1905 \\
1906 \\
1908 \\
1909 \\
1910 \\
1911\end{array}$ & $\begin{array}{l}\text { Puc. Peckii (DeT.) } \\
\text { Kellerm. }\end{array}$ & $\begin{array}{l}\text { Carex lanuginosa } 52,66, \\
85,158,184,208 \\
\text { C. stipata 20, 124 } \\
\text { C. trichocarpa 20, 21, } 52, \\
85,158,184\end{array}$ & $\begin{array}{l}\text { Gaura biennis } 158 \\
\text { Meriolix serrulatu } \\
\text { I8 } 4 \\
\text { Onagra biennis } \\
\text { (Oenothera biennis) } \\
20,21,52,66,85,124 \text {, } \\
158,184,208\end{array}$ \\
\hline $\begin{array}{l}1906 \\
1908 \\
1910\end{array}$ & $\begin{array}{l}\text { Puc. patruelis Arth. } \\
\text { (P. Opizii Arth. not } \\
\text { Bubák) }\end{array}$ & $\begin{array}{l}\text { Carex prutensis } 136 \\
\text { C. siccata } 185 \\
\text { C. } 8 \mathrm{p} .85\end{array}$ & $\begin{array}{l}\text { A goseris glauca } 136 \\
\text { Lactuca cunadensis } \\
85,185 \\
\text { L. saiva } 85,185 \\
\text { L. virosa } 85\end{array}$ \\
\hline
\end{tabular}




\begin{tabular}{|c|c|c|c|}
\hline Year & Rust & Telial host & Aecial host \\
\hline $\begin{array}{l}1901 \\
1902 \\
1904 \\
1905 \\
1906 \\
1908\end{array}$ & $\begin{array}{l}\text { Puc. Sambuci (Schw.) } \\
\text { Arth. (P. Atkinsoni- } \\
\text { ana Diet., P. Bolley- } \\
\text { and Sacc.) }\end{array}$ & $\begin{array}{l}\text { Curex Frankii } 85 \\
\text { C. lupulina } 65 \\
\text { C. lurida } \mathbf{2 1}, \mathbf{1 2 4} \\
\text { C. trichocarpa } \mathbf{1 4}, \mathbf{2 1}, \mathbf{5 2}\end{array}$ & $\begin{array}{c}\text { Sambucus canadensis } 14 \\
2 \mathrm{I}, 52,65,85,124\end{array}$ \\
\hline $\begin{array}{l}1004 \\
1905\end{array}$ & $\begin{array}{l}\text { Puc. Polygoni-amphibii } \\
\text { Pers. }\end{array}$ & $\begin{array}{l}\text { Polygonum emersum } 53 \\
\quad 69,53\end{array}$ & $\begin{array}{l}\text { Geranium maculatum } \\
53.69\end{array}$ \\
\hline 1910 & $\begin{array}{l}\text { Puc. argentala (Schultz) } \\
\text { Wint. }\end{array}$ & Impatiens aurea I89 & Adoxa Moschatellinu $\mathbf{1 8 9}$ \\
\hline I909 & $\begin{array}{l}\text { Urom. Andropogonis } \\
\text { Tracy }\end{array}$ & $\mathbb{A}_{\mathrm{r} 63}$ ndropogon virginicus & Violu cucullata $\mathrm{I}_{3}$ \\
\hline $\begin{array}{l}1902 \\
1917\end{array}$ & $\begin{array}{l}\text { Urom. seditiosus Kern } \\
\text { (U. Aristidae Auth. } \\
\text { not E. \& E.) }\end{array}$ & $\begin{array}{l}\text { Aristidn busirumea } 279 \\
\text { A. oligantha } 23\end{array}$ & $\begin{array}{l}\text { Plantago uristata } 279 \\
P \text {. lanceolata } 279 \\
P \text {. Rugelii } 23\end{array}$ \\
\hline I9I6 & Urom. Sporoboli F. \& E.. & $\begin{array}{l}\text { Sporoholus virginae- } \\
\text { florus } 274\end{array}$ & Allium slellatum 274 \\
\hline I9I 5 & Urom. Hordei Tracy & Hordeum pusillum 263 & $\begin{array}{l}\text { Nolhoscordium striatum } \\
263\end{array}$ \\
\hline $19 \mathrm{II}$ & Urom. Peckianus Farl. & Distichlis spicutu 209 & Atriplex hustatu 209 \\
\hline $\begin{array}{l}1905 \\
1907 \\
1909 \\
1910 \\
1912 \\
1917\end{array}$ & $\begin{array}{l}\text { Urom. Poiemonii (Peck) } \\
\text { Barth. (U. aiumina- } \\
\text { tus Arth., U. Spar- } \\
\text { tinae Farl., } U . \text { Steir- } \\
\text { onematis Arth., } U . \\
\text { magnatus Arth.) }\end{array}$ & $\begin{array}{l}\text { Spartina Michauxiana } \\
76,106,164,198,236 \\
282\end{array}$ & $\begin{array}{l}\text { Collomiu linearis } 236 \\
\text { Polemonium reptans } 198 \\
\text { Polygonatum biflorum } \\
\quad 282 \\
\text { P. commutatum } 282 \\
\text { Steironema ciliatum } 76 \text {, } \\
\quad \text { ro6. I6 } 4 \text {. lanceolatum } 164 \\
\text { Sagnera stellata } 282\end{array}$ \\
\hline $\begin{array}{l}1906 \\
1907 \\
1908 \\
1914\end{array}$ & $\begin{array}{l}\text { Urom. Scirpi (Cast.) } \\
\text { Burr. }\end{array}$ & $\begin{array}{l}\text { Scirpus fluvialilis } 89, \\
\mathbf{1 0 6}, \mathbf{1 2} 8, \mathbf{2 4 2}\end{array}$ & $\begin{array}{l}\text { Cicuta maculata } 89,106, \\
\text { I28 } \\
\text { Sium cicutaefolium } 242\end{array}$ \\
\hline $\begin{array}{l}1903 \\
1910 \\
1912 \\
\text { 1914 } \\
\text { 1917 }\end{array}$ & $\begin{array}{l}\text { Urom. perigynius Halst. } \\
\text { (U. Solidugini- } \\
\text { Caricis Arth.) }\end{array}$ & $\begin{array}{l}\text { Carex deflexa } 190 \\
\text { C. intumescens } 190,234 \\
\text { C. sparganioides } 279 \\
\text { C. tribuloides } 242 \\
\text { C. suria } 37 .\end{array}$ & $\begin{array}{l}\text { Aster ericoides } 190 \\
\text { A. paniculatus } 190,234 \\
\text { A. Tweedyi } 242 \\
\text { Rudbeckia laciniata } 279 \\
\text { Solidago caesia } 37 \\
\text { S. canadensis } 37,234 \\
\text { S. flexicuulis } 37 \\
\text { S. serotinu } 37 \\
\text { S. rugosa I90 }\end{array}$ \\
\hline
\end{tabular}


Arthur: Cultures of Uredineae, 1899-19i7 243

\begin{tabular}{|c|c|c|c|}
\hline Year & Rust & Telial host & Aecial host \\
\hline $\begin{array}{l}1910 \\
\text { r912 }\end{array}$ & $\begin{array}{l}\text { Urom. Junci (Desm.) } \\
\text { Tul. }\end{array}$ & Juncus balticus 191,236 & $\begin{array}{l}\text { A mbrosiu urlemisiue- } \\
\text { folia I9 } \\
\text { A. psilostachya I9I } \\
\text { A. trifida 191 } \\
\text { Cas duus Flodmanii ror, } \\
236\end{array}$ \\
\hline $\begin{array}{l}1906 \\
1907\end{array}$ & $\begin{array}{l}\text { Urom. Silphii (Syci.) } \\
\text { Arth. }\end{array}$ & Juncus tenuis 92, 106 & $\begin{array}{l}\text { Silphium perfoliatum } 92, \\
\text { I06 }\end{array}$ \\
\hline 1908 & $\begin{array}{l}\text { Urom. houstoniatus } \\
\text { (Schw.) Shelt!on }\end{array}$ & $\begin{array}{l}\text { Sisyrinchium gram- } \\
\text { ineum } \mathrm{r} 29\end{array}$ & Houslonia caerulea 129 \\
\hline $\begin{array}{l}1908 \\
1911\end{array}$ & $\begin{array}{l}\text { Gym. Libocedri (P. } \\
\text { Henn.) Kern }\end{array}$ & $\begin{array}{l}\text { Libocedrus decurrens } \\
\mathbf{1 4 3}, \mathbf{2 X I}\end{array}$ & $\begin{array}{l}\text { Amelanchier vulgaris } 2 \mathrm{II} \\
\text { Crataegus cerronis } 2 \mathrm{II} \\
\text { C. Pringlei } \mathrm{I} 43 \\
\text { C. tomentosa } 2 \mathrm{II}\end{array}$ \\
\hline $\begin{array}{l}1907 \\
1911\end{array}$ & $\begin{array}{l}\text { Gym. inconspicuum } \\
\text { Kern }\end{array}$ & $\begin{array}{l}\text { Juniperus utahensis } \\
\quad \mathbf{1} \mathbf{1}_{3}, \mathbf{2 1} \mathbf{1}\end{array}$ & $\begin{array}{l}\text { A melanchier erecla } \mathrm{II} 3 \\
\text { A. vulgaris } 2 \mathrm{II}\end{array}$ \\
\hline 1009) & Ciym. exiguum Kern & $\begin{array}{l}\text { Juniperus virginiana } \\
\text { I69 }\end{array}$ & Crataegus Pringlei I69 \\
\hline $\begin{array}{l}1908 \\
1910\end{array}$ & Gym. Davisii Kern & $\begin{array}{l}\text { Juniperus sibirica } \mathbf{1 3 2} \\
\mathbf{1 9 4}\end{array}$ & $\begin{array}{l}\text { Aronia arbutifolia } 194 \\
\text { A. nigra } 132,194\end{array}$ \\
\hline $\begin{array}{l}1906 \\
1907 \\
1908 \\
1910\end{array}$ & (iym. juvenescens Kern & $\begin{array}{l}\text { Juniperus scopulorum } \\
93,107,130 \\
\text { J. virginiana } 195\end{array}$ & $\begin{array}{l}\text { Amelanchier canadensis } \\
93,107 \\
\text { A. erecta 107, 130, 195 } \\
\text { A. intermedia (A. } \\
\text { Botryapium) 107 } \\
\text { Sorbus americana } 93 \text {, } \\
\text { 107, 130 }\end{array}$ \\
\hline IOII & Gym. Kernianum Bethel & Juniperus utahensis $2 \times 6$ & A melanchier vulgaris 216 \\
\hline 1909 & Gym. trachysorum Kern & $\begin{array}{l}\text { Juniperus virginiana } \\
\mathbf{1 7 2}\end{array}$ & $\begin{array}{l}\text { Crataegus cerronis } 172 \\
\text { C. coccinea } 172 \\
\text { C. punctata I } 72\end{array}$ \\
\hline $\begin{array}{l}1908 \\
\text { r9I4 }\end{array}$ & $\begin{array}{l}\text { Gym. Botryapites } \\
\text { (Schw.) Kern }\end{array}$ & $\begin{array}{l}\text { Chamuecy paris thyoides } \\
\text { I31, } \mathbf{2 4 2}, \mathbf{2 4 3}\end{array}$ & $\begin{array}{l}\text { Amelunchier canadensis } \\
242,243 \\
\text { A. intermedia } \mathrm{I} 3 \mathrm{I}\end{array}$ \\
\hline $\begin{array}{l}1907 \\
1909 \\
1910 \\
1911 \\
1914\end{array}$ & Gym. nidus-avis Thax. & $\begin{array}{l}\text { Juniperus virginiuna } \\
108,129,165,194, \\
210,242\end{array}$ & $\begin{array}{l}\text { Amelanchier erecta } 210 \\
\text { A. vulgaris I94, } 242 \\
\text { Cratuegus Pringlei } 165 \\
\text { Cydonia vulgaris } 194 \\
\text { Malus coronaria } 129 . \\
210 \\
\text { M. Malus } 108,129 \\
\text { M. ioensis } 165\end{array}$ \\
\hline
\end{tabular}




\begin{tabular}{|c|c|c|c|}
\hline Year & Rust & Telial host & Aecial host \\
\hline $\begin{array}{l}1907 \\
1908 \\
1909 \\
1910\end{array}$ & Gym. clavipes C. \& P. & $\begin{array}{l}\text { Juniperus sibirica } \\
\text { 107, 164, 193 } \\
\text { J. virginiana } 130\end{array}$ & $\begin{array}{l}\text { Amelanchier erecta } \\
\quad 107,164,193 \\
\text { A. intermedia I07 } \\
\text { Cratuegus punctala } 164 \\
\text { C. tomentosa } 193 \\
\text { C. sp. } 130\end{array}$ \\
\hline $\begin{array}{l}1908 \\
1909 \\
1910\end{array}$ & $\begin{array}{l}\text { Gym. cornutum (Pers.) } \\
\text { Arth. }\end{array}$ & $\begin{array}{c}\text { Juniperus sibirica } \\
\mathbf{1 3 1}, \mathbf{1} 65, \mathbf{1 9 4}\end{array}$ & $\begin{array}{l}\text { Sorbus americana I3I, } \\
\text { I65, I94 } \\
\text { S. aucuparia } 165\end{array}$ \\
\hline $\begin{array}{l}1908 \\
1909\end{array}$ & $\begin{array}{l}\text { Gym. cxlerumaArth. \& } \\
\text { Kern }\end{array}$ & $\begin{array}{l}\text { Juniperus virginiana } \\
\mathrm{x} 44, x 66\end{array}$ & $\begin{array}{l}\text { Porteranthus stipulatus } \\
\text { I44, I66 }\end{array}$ \\
\hline I9II & $\begin{array}{l}\text { Gym. juniperinum (L.) } \\
\text { Mart. (G. tremel- } \\
\text { loides Hartig) }\end{array}$ & Juniperus sibirica 2 II & Sorbus americana 2 II \\
\hline $\begin{array}{l}\text { I9I I } \\
\text { I9I2 }\end{array}$ & $\begin{array}{l}\text { Gym. gracilens (Peck) } \\
\text { Kern \& Bethel }\end{array}$ & $\begin{array}{l}\text { Juniperus monosperma } \\
2 \mathrm{I} 7 \\
\text { J. utahensis } \mathbf{2 3 7}\end{array}$ & $\begin{array}{l}\text { Philudelphus coronarius } \\
217,237 \\
\text { P. Keteleerii } 237\end{array}$ \\
\hline IgII & Gym. efiusum Kern & $\begin{array}{l}\text { Juniperus virginiand } \\
2 \text { I } 7\end{array}$ & Aronia arbutifolia 217 \\
\hline $\begin{array}{l}1907 \\
1908 \\
1910 \\
1911 \\
\text { I9I3 }\end{array}$ & $\begin{array}{l}\text { Gym. cluvariueforme } \\
\text { (Jacq.) DC. }\end{array}$ & $\begin{array}{c}\text { Juniperus sibirica ro8, } \\
\mathbf{1 3 0}, \mathbf{1 9 4}, 210,238\end{array}$ & $\begin{array}{l}\text { Amelunchier ereclu } 130 \text {, } \\
\quad \text { I94. } 2 \text { I0 } \\
\text { A. intermedia } 108 \\
\text { Crataegus cerronis } 238 \\
\text { C. punctata r } 94\end{array}$ \\
\hline 1914 & $\begin{array}{l}\text { Crym. E.llisii (Berk.) } \\
\text { Farl. }\end{array}$ & $\begin{array}{l}\text { Chamaecyparis thyoides } \\
246\end{array}$ & Myrica cerifera 246 \\
\hline $\begin{array}{l}1907 \\
1908 \\
1909 \\
1910 \\
\text { I912 }\end{array}$ & Gym. Betheli Kern & $\begin{array}{l}\text { Juniperus scopulorum } \\
112,113,131,165 \\
195,237\end{array}$ & $\begin{array}{l}\text { Crataegus cerronis } \\
\quad 165, \text { I95 } \\
\text { C. coccinea II2 } \\
\text { C. cordata II3 } \\
\text { C. Pringlei } 237 \\
\text { C. punctata II } 2 \\
\text { C. sp. } 131 \\
\text { Sorbus americana II2, } \\
\text { II3, I3I }\end{array}$ \\
\hline $\begin{array}{l}1906 \\
1907 \\
1908 \\
1909\end{array}$ & Gym. globosum Farl. & $\begin{array}{c}\text { Juniperus virginiana } \\
90,107,130,164\end{array}$ & $\begin{array}{l}\text { Cratuegus coccinea I64 } \\
\text { C. Pringlei 90, I30 } \\
\text { Mulus coronaria } 90 \\
\text { M. Malus (Pyrus } \\
\text { Malus) I07 } \\
\text { Sorbus americana } 90\end{array}$ \\
\hline $\begin{array}{l}\text { I9I I } \\
\text { I9I2 }\end{array}$ & Gym. Nelsoni Arth. & $\begin{array}{l}\text { Juniperus scopulorum } \\
237 \\
\text { J. utahensis } 215\end{array}$ & $\begin{array}{l}\text { Amelanchier cunadensis } \\
237 \\
\text { A. vulgaris } 2 \text { I } 5\end{array}$ \\
\hline
\end{tabular}


Arthur: Cultures of Uredineae, is99-igi 312

\begin{tabular}{|c|c|c|c|}
\hline Year & Rust & Telial host & Aecial host \\
\hline 1909 & Gym. corniculans Kern & $\begin{array}{l}\text { Juniperus horizontalis } \\
\quad 170\end{array}$ & $\begin{array}{l}\text { A melunchier canudensis } \\
170 \\
\text { A. erecta } 170\end{array}$ \\
\hline $\begin{array}{l}1908 \\
1909\end{array}$ & Gym. floriforme Thax. & $\begin{array}{l}\text { Juniperus virginiana } \\
\quad \times 29.166\end{array}$ & $\begin{array}{l}\text { Crataegus coccinea I } 66 \\
\text { C. punctata } 129\end{array}$ \\
\hline $\begin{array}{l}1905 \\
1906 \\
1907 \\
1908 \\
1910\end{array}$ & $\begin{array}{l}\text { Ciym. Iuniperi- } \\
\text { virginianae Schw. } \\
\text { - }\end{array}$ & $\begin{array}{l}\text { Juniperus virginianu } \\
64,90,106,129,193\end{array}$ & $\begin{array}{l}\text { Malus coronuria } 90,129 \\
\text { M. Malus (Pyrus } \\
\text { Malus) 64, 106, } 129 . \\
\text { I93 }\end{array}$ \\
\hline $\begin{array}{l}1905 \\
1906\end{array}$ & $\begin{array}{l}\text { Tranz. punctata (Pers.) } \\
\text { Arth. (Puc. Pruni- } \\
\text { spinosae Pers.) }\end{array}$ & $\begin{array}{l}\text { Prunus pumila } 89 \\
\text { P. serotina } 71,89\end{array}$ & $\begin{array}{l}\text { Heputica uintiloba } \\
7 \mathbf{7}, 89\end{array}$ \\
\hline $\begin{array}{l}1903 \\
1904 \\
1905 \\
1908\end{array}$ & Mèl. Medusae Thüm. & $\begin{array}{l}\text { Populus delloides } 35,46 . \\
\quad 64 \\
\text { P. tremuloides } 47, \mathbf{1 3 3}\end{array}$ & $\begin{array}{l}\text { Larix decidua } 35,46,47, \\
\quad 64 \\
\text { L. laricina } 46,64,133\end{array}$ \\
\hline $\begin{array}{l}\text { I9IO } \\
\text { r9II }\end{array}$ & Mei. albertensis Arth. & $\begin{array}{l}\text { Populus tremuloides } \\
\quad 198,212\end{array}$ & $\begin{array}{l}\text { Pseudotsuga mucronata } \\
198,212\end{array}$ \\
\hline $\begin{array}{l}1904 \\
1906\end{array}$ & Mel. Bigelozvii Thüm. & $\begin{array}{l}\text { Salix amygdaloides } 54 \\
\text { Salix sp. } 84\end{array}$ & Larix decidua 54,84 \\
\hline roro & $\begin{array}{l}\text { Mel'sis abiclina (A. \& } \\
\text { S.) Arth. }\end{array}$ & $\begin{array}{l}\text { Ledum groenlandicum } \\
\quad 195\end{array}$ & Piceu mariana 195 \\
\hline I010 & $\begin{array}{l}\text { Mel'ella elatina (A. \& } \\
\text { S.) Arth. }\end{array}$ & $\begin{array}{l}\text { Cerustium oreophilum } \\
2 \mathrm{I} 2\end{array}$ & Abies lasiocarpu 212 \\
\hline 1909 & $\begin{array}{l}\text { Calyp. columnaris (A. \& } \\
\text { S.) Körn. }\end{array}$ & $\begin{array}{l}\text { Vaccinium pennsyl- } \\
\text { vanicum } \mathrm{x} 66\end{array}$ & Abies Fraseri 166 \\
\hline $\begin{array}{l}\text { I906 } \\
1910 \\
\text { I913 }\end{array}$ & $\begin{array}{l}\text { Cron. Quercus (Brond.) } \\
\text { Schroet. }\end{array}$ & $\begin{array}{l}\text { Quercus Phellos } 238 \\
\text { O. rubru } 195,238 \\
\text { Q. velutina } 84\end{array}$ & $\begin{array}{l}\text { Pinus virginiana } 84,195 \\
\text { P. taeda } 238\end{array}$ \\
\hline $\begin{array}{l}1010 \\
1911 \\
1913 \\
1914\end{array}$ & $\begin{array}{l}\text { Colens. Vernoniae B. \& } \\
\text { C. }\end{array}$ & $\begin{array}{l}\text { Vernonia crinita } 198 \\
\text { V. fasciculata } 239,243 \\
\text { V. gigantea } 2 \mathrm{II}\end{array}$ & $\begin{array}{l}\text { Pinus pulustris } 239 \\
\begin{array}{l}P \text {. Lueda } 198,211,239 \\
243\end{array}\end{array}$ \\
\hline
\end{tabular}




\section{Mycologia}

INDEX

A consecutive paging of the reports has been adopted in order to simplify the index. It corresponds to the original paging as follows :

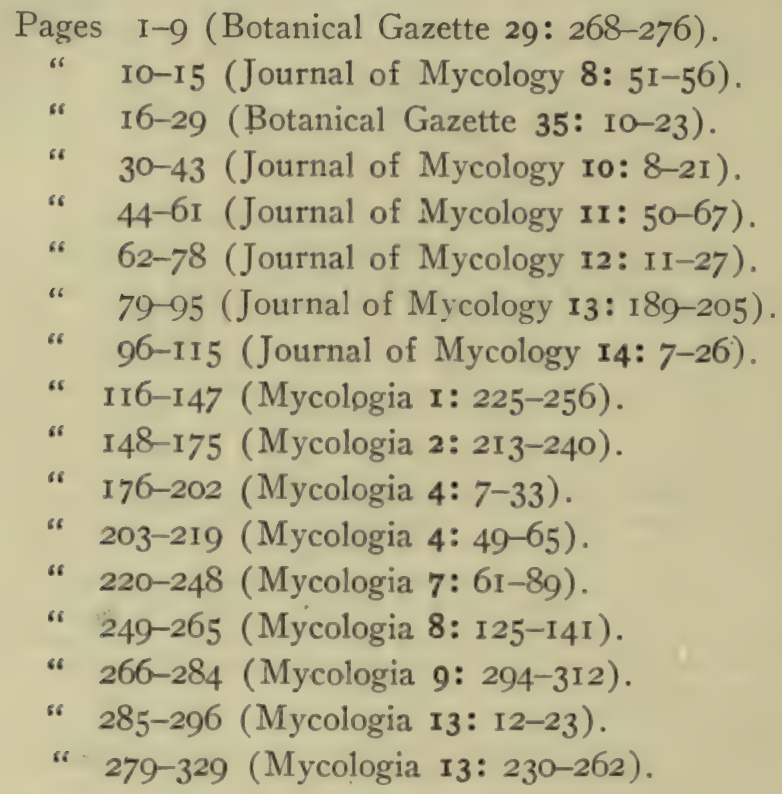

Names in italics are synonyms.

Numbers in broad-faced type indicate successful cultures.

Numbers in square brackets refer to pages (I) where the common name is used for the species instead of the Latin name, or (2) where the name occurs but is not the species intended and not a synonym (e.g., Anchusa officinalis for Lycopsis arvensis), or (3) where the name does not occur but some other name not a synonym (the error being due to wrong identification, e.g., Gymnosporangium Nelsoni used for G. juvenescens, or to common but erroneous usage, e.g., Spartina cynosuroides for $S$. Michauxiana). 


\section{Artilur: Cultures of Uredineae, i890-1917 31.47}

\section{Fungus Index}

Aecidium abundans (Puc. Crandallii) 197

albiperidium (Puc, Grossulariae) 12, 15

alliicolum (Urom. Sporoboli) 273, 275

Asterum (Puc. extensicola) 13, 15 Berberidis (Puc. poculiformis) 15 Blasdaleanum (Gym. Libocedri) 143

Calystegiae (Puc. Convolvuli) - 9

Ceanothi (Puc. Ceanothi) 168

Cephalanthi (Puc. Seymouriana) 75

Clematidis or Clematitis (Puc. Agropyri) 57

compositarum Silphii (Urom. Silphii) 92

cornutum (Gym. cornutum) 132

Dracunculi (Puc. universalis) 110 elatinum (Melampsorella elatina) 212

erigeronatum. (Puc. extensicola) 13,15

Euphorbiae (Urom. Euphorbiae) 9, I 5

Fraxini (Puc. fraxinata) 8, 9

fumariaceum (Puc. subnitens) 278

hepaticatum (Puc. Pruni-spinosae) 71

houstoniatum (Urom. houstoniatus) 128

Hydrophylli (Puc. apocrypta) 262, 265

hynoideum 41

Impatientis (Puc. Impatientis) 24

Iridis (Puc. Majanthae) 253

Jamesianum (Puc. Jamesiana) 24

leucospermum (Urom. Lespedezaeprocumbentis) 36

Liatridis (Puc. Liatridis) 273

Lycopi (Puc. angustata) 6, 9, 15

macrosporum (Puc. macrospora)

135

magnatum (Urom. magnatus) 282

malvicola (Puc. Muhlenbergiae) monoicum (Puc, monoica) 213

Napaeae (Puc. Muhlenbergiae)

142

Nesaeae (Puc. minutissima) 245

obesum (Puc. Seymouriana) 258, 265

occidentale (Puc. Agropyri) 57

Oxalidis (Puc. Sorghi) 59

Pammelii (Puc. Pammelii) 50

Peckii (Puc. Peckii) 19

Pentstemonis (Puc. Andropogonis)

5, 9

Phrymae (Puc. Phrymae) III

Polemonii (Urom. acuminatus) 198

Pteleae (Puc. Windsoriae) 6, 9, 22 punctatum (Puc. Pruni-spinosae) 70

pustulatum (Puc. pustulata) 39

Ranunculi (Puc. Eatoniae) 40

rubellum (Puc. Phragmitis) 3, 9

Sambuci (Puc. Sambuci) 14, 15, 20

sanguinolentum (Puc. Polygoni-

amphibii) 32, 53, 69

sclerothecioides (Puc. Stipae) 189

Silphii (Urom. Silphii) 92

Solidaginis (Puc. extensicola) 27

Urticae (Puc. Caricis) 3, 9, 15

verbenicola (Puc. verbenicola) 7 , 9, 22

Bullaria tumidipes 260

Vernoniae 274

Caeoma erigeronatum (Puc. extensicola) $\quad 13$

miniata (Phrag. speciosum) 4, 9

occidentale (Melampsora albertensis) 199

Ulmariae (Triphragmium Ulmariae) 9

Calyptospora columnaris 166,175

Coleosporium Campanulae 46

Vernoniae 198, 202, 211, 219, 239, 243,248

Cronartium Quercus 84, 94, 195, 202. 239, 248

Gymnoconia interstitialis 207 
Gymnosporangium Betheli II2, II5, 131, 147, 165, 174, 194, 201, 237, 247

biseptatum (G. Botryapites) 131

Botryapites 131, 147, 242, 248

clavariaeforme 108, 115, 130, 146,

193, 20I, 210, 218, 238, 247

clavipes 107, 115, 130, 146, 164,

$174,193,201$

corniculans 170, 171, 175

cornutum 131, 147, 165, 174, 194, 201

Davisii 132, 147, 151, 194, 201

durum (G. Nelsoni) 215, 219, 237, 247

effusum 216, 219

Ellisii 245, 248

exiguum 169,175

exterum 144, 147, 166, 175

floriforme [129], [146], 166, 174

globosum 90, 95, 107, 114, 130, 146, $164, \quad 574$

gracilens $217,219,237,247$

inconspicuum II3, II5, 2II, 218

juniperinum 211, 219

Juniperi-virginianae $64,77,90,95$, 106, 114, 129, 146, 193, 201 juvenescens [93], [95], [ro7], [i14], [130], [146], [195], [20I], 216

Kernianum 216, 219

Libocedri 143, 147, 211, 219 macropus (G. Juniperi-virginianae) 65

Nelsoni [93], [95], [107], [114], [130], [146], [195], [201], $215,219,237,247$

Nidus-avis 108, I15, 165, I74, 194, 20I, 210, 218, 242, 248

speciosum (G. gracilens) 217

trachysorum I72, I75

tremelloides (G. juniperinum)

I32, 2II, 219

Lecythea macrosora (Mel. Bigelowii) 55

Melampsora albertensis 198, 202, 212, 219

Bigelowii 54, 6r, 84, 94

Lini 9r, 95
Medusae $35,42,46,60,64,77$, I33, 147

paradoxa (M. Bigelowii) 55

Melampsorella elatina 212, 219

Melampsoropsis abietina 195, 202

Nigredo Polemonii 282

Peridermium carneum (Coleos. Vernoniae) I98, 211, 239, 243

Cerebrum (Cronart. Quercus) 84, 195

fusiforme (Cronart. Quercus) 238, 248

Phragmidium speciosum 4, 9, 23, 28, $47,60,106,114$

Puccinia Absinthii 134, 147, I90, 201 Agropyri [100], 104, 114, 232, $24 \mathrm{I}, 247,252,[256],[265], 276$, 292,293

albiperidia (P. Grossulariae) 12, 15. $33,42,52,61,65,77,86,94$, 102, $113,184,226,227,237,246$, 290

alternans (P. Agropyri) 139, 147, [256], [265], 293

americana (error for P. Andropogonis) [5], [9]

amphigena 26, 29, 33, 42, 67, 77, 104, $114,160,173,187,200,250$ Andropogonis [5], [9], 33, 42, 87, $94,186,200$

angustata 6, 9, 12, 15, 52, 61, 86, $94,103,114,125,146,186,200$, 208, $218,229,247$

Anthoxanthi I 80

apocrypta (partly error for P. montanensis) [26I], 262, [263], [265]

argentata 189, 201

Arundinariae 100

Asperifolii 127, 146, 257, 265

Asteris 123

Asterum 288

Atkinsoniana (P. Sambuci) II, 20, 2 I

Bartholomaei (P. Jamesiana) 24

Blasdalei [112], [ I15]

Bolleyana (P. Sambuci) I4, I5, 20, 21, 52

canaliculata 74,78 


\section{6 \\ Arthur: Cultures of Uredineae, I899-igil ? 249}

caricina $1 x, 293$

Caricis 3, 9, $11,15,22,28,66,77$, $103,113,158,173,186,200,293$ Caricis-Asteris ( $\mathrm{P}$. extensicola) $13,15,21,28,102,1 \times 3,159$ $173,185,197,199,228,246,287$

Caricis-Erigerontis ( $P$. extensicola) $12,15,21,28,52,61,287$ Caricis-Solidaginis . ( $\mathrm{P}$. extensicola) $27,29,66,77,124,146$, $184,199,228,246,287$

Caricis-strictae 66

caulicola 36,42

Ceanothi 168, 175

Chloridis 18

cinerea (P. Agropyri) 137, 147, 208, 218, 292, 293

Clematidis 293

Cockerelliana [256], [265]

Convolvuli 3,9

Crandallii 64, 100, 196, 202

Cryptandri [109], [115], 223, 280

Distichlidis $154,180,260,265,271$, 275,291

Dulichii (P. extensicola) I2I, 240, $246,254,264$

Eatoniae 40, 42, 295

Eleocharidis $17,74,78,87,94,124$, 146

Ellisiana 99, 122, $155,178,230$, 247

emaculata $11,18,32,63,82,100$, $121,224,251,276$

Eriophori 255, 265

exitiosa (P. transformans) 73

extensicola 229, 238, 239, 246, 254, $264,288,289$

fraxinata $51,60,67,77,103,114$, 127, 146, 160, 174

graminis (P. poculiformis) 295, 296 Grindeliae 72, 78

Grossulariae 182, 199, 225, 246, $254,265,290$

Helianthi 23, 28, 34, 42, 47, 60, $69,78,287$

hydnoidea (error) 4r, 42, 57

Impatientis 25, 29, 33, 42, 51, 6o, 16x, 174, 292

Isiacae 294
Jamesiana 24, 28, 188, 200

Koeleriae 138,147

Kuhniae 74, 78, 124, 145

lateripes $69,78,294$

Liatridis 273, 275, 292

Lithospermi 197, 202

ludibunda 46

Lygodesmiae 212, 219

macrospora 135,147

Majanthae 277, 284

McClatchieana 223

minutissima 245, 248

monoica 215, 219, 234, 247

montanensis (partly error for $P$. apocrypta) [100], [180], [26I], $262,[263],[265]$

Muhlenbergiae 17, 142, 147, 161, $174,187,200,241,247,271,275$ mutabilis [112], [115]

nigrescens ( $\mathrm{P}$. caulicola) 37

nodosa 244,248

obliterata (P. Agropyri) 141, 147, 160, 174, 293

obtecta 109, II5

Opizii (P. patruelis) $84,94, \mathbf{1 8 5}$, 200

Pammelii 50, 60, 67, 77, 105, I14 Panici (P. Pammelii) 50

Paniculariae (P. Agropyri) 18

patruelis 136,147

Peckii 11, 19, 28, 52, 61, 66, 77,

$85,94,124,145,157,173,184$, 199, 208, 218

peridermiospora (P. fraxinata) 8, 9

perminuta (P. Impatientis) 178

Phragmitis 2, 9, 104, 114, 160, 174, 208, 218

Phrymae III, II5

poculiformis $12,15,5 x, 61,68,77$, $88,94,105,114,122,162,174$, $187,200,270,275$

Podophylli 59, 61

Polygoni-amphibii $18,31,53,61$, $69,78,82$

Pruni-spinosae (Tranzschelia punctata) $70,78,89,94$

purpurea 18

pustulata $40,42,67,77,186,200$ 
quadriporula (P. Grossulariae) 197, 202, 235, 246

quadriporula (error for Urom. perigynius) [197], [202], 235

Rhamni 52, 6x, 187, 200, 252, 27x, 275

Ribesii-Caricis (P. Grossulariae) 228

rubigo-vera II, I28, I54, 291, 293 Ruelliae 294

Salviae-lanceolatae (P. caulicola) 37

Sambuci 2x, 28, 52, 65, 77, 85, 94, I24, 146

Schedonnardi (P. Muhlenbergiae) I7, 82, 100, 122, 179, 207, 271, 275

Seymouriana $75,78,127,146,188$, $200,249,258,265$

Silphii 72, 78, 88, 94

simillima 26, 29, 104, I14, 251

Solidaginis 73,78

Sorghi 59, 6r, 68, 78

Sporoboli $18,279,284$

splendens 244, 248

Stipae I8, 57, 59, 6r, 188, 200, 231, 247

striatula (P. Majanthae) $\mathrm{I}_{54}$

subnitens $25,29,48,60,67,77,87$,

$94,104,114,125,146,160,173$,

I87, 200,208, 209, 218, 259, 265,

$272,275,278,284,289,293,294$ substerilis 75, 78, [109], [115], 154, 163,174

Sydowiana (P. verbenicola) 7

tenuistipes 102

tomipara (P. Agropyri) [4 I ], 56,

$61,87,94,127,146,233,293$

tosta (P. Muhlenbergiae) 32, 63,

179, 206, 240, 247

transformans $73,78,88,94$

triticina (P. Agropyri) 276, 292, 293

tumidipes 26o, 265

uniporula ( $\mathrm{P}$. Grossulariae) 226, $227,254,265$

universalis IIo, I15, I59, 173, 185, $200,270,275^{\circ}$ verbenicola $[7],[9], 22,28,50$, $60,67,77$

Vernoniae 274, 275

vexans 32,109, II 5,122

Vilfae (P. verbenicola) 7, 9, 22

virgata $99,154,179$

vulpinoidis ( $\mathrm{P}$. extensicola) $\mathrm{I} 20$, $238,246,288$

Windsoriae $6,9,22,28,50,60$, 259, 265

Xanthii $71,78,88,94$

Pucciniastrum Hydrangeae 277

Roestelia Betheli (Gym. Betheli) $1 \mathbf{3}$ cornuta (Gym. cornutum) 118,150 Harknessianoides (Gym. inconspicuum) I 33

hyalina (Gym. hyalinum) 150

penicillata (Gym. juniperinum) I1 8,132

Tranzschelia punctata (Puc. Prwnispinosae) 139

Tremella juniperisa (Gym, juniperinum) 132

Triphragmium Ulmariae 4 , 9

Uredo Oxytropi (Urom. Astragali) 192

rubigo-vera (Puc. Agropyri) T9, 28

Uromyces acuminatus $31,75,78,83$, 106, 114, 156, 198, 202, 236, 247,283

Andropogonis 123, 163, 174

Archerianus 253

Aristidae (U. seditiosus) 23, 28

Astragali 192, 201

Caricis (Puc. Caricis-strictae) 66

effusus 83,93

elegans 244, 248

Eleocharidis $83,18 \mathrm{I}$

Euphorbiae 3, 9, 10, 15, 18, 28, 287

graminicola $64,123,-155,18 \mathrm{r}, 269$

Halstedii I 7

Hordei 263, 265

houstoniatus 128, 146

Junci 17, 64, 93. гот, 155, т9x, 201, 235, 247

Lespedezae-procumbentis 36,42 magnatus 283,284 


\section{Arthur: Cultures of Ureineae, $1899-$ hig 318}

Medicaginis 193, 201, 210, 218

Murrilli (U. houstoniatus) 128

Orobi 101

Peckianus $18 \mathrm{r}, 209,218,289$

perigynius 38, 190, [197], 201,

$234,242,247,279,284,288,293$

Phaseoli 36,42

Polemonii 282, 291

Rhyncosporae 101, 224

Scirpi 89, 94, 106, 114, 128, 146,
$242,247,253$

seditiosus 278,284

Silphii 92, 93, 95, 106, I 44

Solidagini-Caricis (U. perigynius)

38,42

Spartinae $164,174,181,283$

Sporoboli 17, 182, 225, 273, 275 , 280

Steironematis 283

uniporulus 183,291

\section{Host Index}

Abies alba 167

balsamea $17,167,277$

concolor 167,277

Fraseri 166, 167, 175

lasiocarpa 212, 219

magnifica 167

nobilis 167

Abronia fragrans $155,273,275,278$

umbellata 121, 223

Actaea alba 46, 51, 81, 82, 99, 122, I54, $162,178,223$

rubra 81

Adelia acuminata 51,67

ligustrina $5 \mathrm{I}, 127$

segregata 51,127

Adoxa moschatellina 189,201

Aesculus glabra 18, 63, 81, 98, 99, $100,101,155,-180,181,206,207$, 224

Agoseris glauca $136,147,159$

Agropyron biflorum 140, 142, 147

caninum 142

glaucum 276

pseudorepens 105, 114, 162, 174

repens $5 \mathrm{I}, 6 \mathrm{I}, 10 \mathrm{I}, 163$

Smithii 232, 247, 270, 275, 276

sp. 105, 160, 174

tenerum 51, 61, 105, 114, 163, 187, $200,262,265$

Agrostis alba $68,77,88,94,163,187$, 200

hyemalis 178

perennans 178

sp. 271, 275

Allium Brandegei [112], [115]

canadense 274,280 cernuum [112], [115], 280, 284

Nuttallii 280, 284

recurvatum [112], [115]

reticulatum [112], [115] 225, 274

stellatum 273, 275, 278, 280

Althaea rosea $81,82,123,155,161$, 187

Ambrosia artemisiaefolia $63,76,92$, 236

psilostachya 192, 235, 236, 247

trifida $6, \mathrm{II}, 25,32,45,65.7 \mathrm{I}, 8 \mathrm{I}$, 82,92 , 101, $120,121,122,134$,

I $53,154,168,180,191,236,247$

Amelanchier Botryapium 65, 107, 133

canadensis 93, 95, 101, 107, 108, $109,113,114,143,165,169,170$, $171,175,217,237,242,243,247$, 248

erecta 107, 113, 114, I15, 130, 132, $146,157,164,165,170,171,174$,

$175,194,195,201,207,210,211$, $216,217,218$

intermedia 107, 108, 114, 115, 131, 147,171

sp. 90

vulgaris 133, 194, 201, 211, 215, $216,217,218,219,242,248$

Amorpha fruticosa 121, $179,18 \mathrm{r}$ nana $168,179,180,182$

Amsonia salicifolia 243, 258

Amygdalis communis 70 persica 71,89

Anchusa officinalis [257], [265]

Andropogon furcatus 6, 39, 42, 67, $77,186,200$

glomeratus 123,155 
Hallii $168,169,175$

scoparius $5,6,33,39,42,87,94$,

$99,122,155,178,186,200$

sp. $186,230,247$

virginicus $163,174,186,200$

Anemone canadensis $17,19,26,29$,

64, 104, II4, 252

coronaria 70

cylindrica 26, 232, 247, 251, 252, 256,276

pennsylvanica 32

ranunculoides $7 \mathrm{I}$

virginiana $17,26,81,104,122$

Anemonella thalictroides 81, 82, 98, I78

Anthoxanthum odoratum 180

Apios Apios (A. tuberosa) 46, 8r, 82, 123, 179, 181, 225

Apocynum cannabinum 17, 24, 32, I0I, 122, 153, 178, 179, 180, 181, $182,197,224,258,265$

hypericifolium 258

Aquilegia caerulea 101, 141, 232

canadensis $64,140,147,178,242$, 256

elegantula $14 \mathrm{I}$

flavescens $14 \mathrm{I}, 232,242$

formosa $14 \mathrm{I}$

sp. 252

truncata I4I

Arabis Drummondii 214

Holboellii 120, 154, I59, 179, 180, 189

retrofracta 215

sp. 99, 101, 213, 214, 219, 234, 247

Aragallus Lamberti 192, 201

Arisaema triphyllum $9 \mathrm{I}$

Aristida basiramea 279, 284

oligantha 23,28

ramosissima 279

Arnica sp. I55, I79, 180, 182, 189, I9I, 196

Aronia arbutifolia 108, 157, 194, 201 , 217, 219, 242

nigra $93,130,132,147,165,194$, $20 \mathrm{I}$

rotundifolia $\mathrm{I} 33$

Artemisia canadensis III dracunculoides 99, IIO, III, II5, $121,134,147,154,159,173,185$,

190, 200, 201, 269

dracunculus Iro, III

frigida III

gnaphalodes 270, 275

kansana III

longifolia 159

ludoviciana 190

serrata 99

sp. 190, $20 \mathrm{I}$

Arundinaria macrosperma 100

Asclepias incarnata 24, 28, 45

pulchra 258

syriaca 24, 28, 188, 200, 258, 259, 265

verticillata 225

Asclepiodora decumbens 24

Asprella Hystrix 262

Aster adscendens 159, 173, 185, 199

arenarioides [123]

cordifolius II, I3, I4, 58, I02, II 3

Drummondii 32, 58, 66, 121, I23, $124,153,178,190,238,240,242$ ericoides $32,58,59,61,75,154$, $188,190,200,20 \mathrm{I}, 23 \mathrm{I}$

laterifiorus 279

multiflorus $57,58,59,61,75,123$, $153,154,188,200,231$

Novae-Angliae 58, 59, 61, 75, 188, 200, 23I.

paniculatus II, I2, I3, I4, I9, 20, 2I, 28, 32, 58, 66, 100, 102, III, I13, 120, I21, I23, 124, I53, 179 . $182,184,190,197,201,202,224$, 228, 229, 234, 235, 238, 240, 242, $243,246,247,254$

prenanthoides 20,32

sericeus 58

Shortii 19

Tripoli 229

Tweedyi 153, 159, 185, 240, 242, 247

Astragalus canadensis 182

carolinianus 192, 201

sulphurescens 192, $20 \mathrm{r}$

Atheropogon curtipendulus 24, 28, $109,115,122,188,200$ 
Artilur: Cultures of Uredineae, I899-19i7 5 25:3

Atriplex confertifolia 206

hastata 126, 146, 160, 173, 208, 209, 218,289

Avena sativa 52, 61, 88, 105, 114,163

Baptisia bracteata 225

leucantha 110

tinctoria $45,142,155,168$

Berberis Aquifolium 138

repens 138

vulgaris $12,51,61,68,77,88,94$, $105,114,122,138,162,174,180$, $187,200,270,271,275$

Berula angustifolia 89

Bidens connata rog, II5

frondosa 17 , 101, 109, 110 , II 5

Boehmeria cylindrica $153,158,162$, I68, I79, 186,197

Boltonia asteroides $18,32,8 \mathrm{r}, 99$, $12 \mathrm{I}, 179,18 \mathrm{r}, 189,269,270$

Bouteloua curtipendula (see Atheropogon) 24,32

racemosa 109,122

Brauneria purpurea 18

Brodiaea pauciflora 244, 248

Bromus ciliatus $11,19,41,42,56,57$, 6 I, 276

Porteri 139, 140, 147

Pumpellianus 139,140

purgans $57,87,94,127,146$

Richardsoni 140

Bursa bursa-pastoris $68,77,87,100$, I04, II 4, 209

Cacalia reniformis $8 \mathrm{x}, \mathrm{x} 20, \mathrm{x} 2 \mathrm{I}, \mathrm{123}$

Calamagrostis canadensis 154,187 , 200

Calamovilfa longifolia 26, 29, 33, 42, $67,77,104$, I14, I60, I73, I87, 200,250

Callirhoe digitata 223, 224, 240, 24 I involucrata $32,81,82,83,120,123$, $142,147,154,155,161,174,187$, $200,207,224,240,24$ I

Callistephus hortensis 123

Campanula americana 46

Campsis radicans $\mathbf{7 3}$

Capnoides montanum 277, 278

Cardamine bulbosa 100, 126

Carduus Flodmanii 180, I9I, I92, $201,236,247$ undulatus $154,158, x 68$

Carex aquatilis (error for C. nebras-

kensis) [66], [77]

arctata $178,226,246,254,265$

aristata $158,173,186,200$

Backii 153, 269

blanda (see tetanica)

Bonplandii minor 153

brunnescens 197

cephalophora 3

comosa 119, 134, 136, 147

crinita $53,61,86,94,102,113,226$, 246

deflexa 190, 191, 201

Douglasii 99

durifolia 255,269

extensa 229

festiva $159,173,185,199$

festucacea $13,21,28,52,61$

filifolia 270,275

filiformis 245,248

foeneia $13,14,21,28$

Frankii 85, 94

Goodenovii 197, 202, 235

gracillima $33,38,39,42,53,61,183$

gravida $32,46,8 \mathrm{I}, 99,12 \mathrm{I}$

intumescens 190, 191, 201, 234, 247

Jamesii 27, 29, 66, 255

lanuginosa $37,38,39,52,61,66$,

$77,85,94,157,173,184,199$,

208, 218

longirostris $111, I 12, I 15$

lupulina $65,77,85$

lurida II, 21, 28, 85, 124, 146

maritima $22 \mathrm{I}$

nebraskensis (under C. aquatilis)

[66], [77]

pallescens $182,183,199$

pennsylvanica $32,45,63,81,98$,

I $20,176,178$

praecox ${ }^{1} 58$

pratensis $136,137,147$

pubescens 12, 38, 39, 183, 225, 226, 246,254

retrorsa 228,246

riparia $22,28,103$, I 33

rosea 102, I I 3 
scoparia 184, I91, I99, 228, 229, 246

siccata I54, 185, 200

sparganioides $66,77,124,146,279$, 284

sp. 85,94, I02, I $21,208,237$

squarrosa 86,94

stellulata 178

stenophylla Ixo, II I, II5, I34, I59,

$173,185,200,270$

stipata $20,27,28,29,66,77,103$,

I I 3, I 24, I 45

stricta $3, \mathrm{II}, 22,28,66, \mathrm{I} 86,200$

tenella I53, I78

tenuis $153,182,183,199,226,246$,

254,265

tetanica (error for blanda) I1, 65,

$77,86,94$

tribuloides 242,247

trichocarpa II, 14, 19, 20, 21, 28,

$52,61,85,94,158,173,184,199$

trisperma 178

varia $37,38,39,42$, [102], [r91]

virescens 38,39

vulpinoidea 1.20, 238, 240, 246

Cassia chamaecrista $17,18,32,64,76$,

$81,83,99,100,101,155,168,180$.

181,225

Caulophyllum thalictroides 82,99 , $122,162,178$

Ceanothus americanus 17, 32, 81, 82, $99, I_{42}, 154,155, x 68,175$

ovatus 168

Cephalanthus occidentalis $75,78, \mathbf{I 2 7}$, I $46,188,200,258$

Cerastium oreophilum 212, 2 I9

Chamaecyparis thyoides I3I, I47, $242,245,248$

Cheiranthus Menziesii 2 I3

Chelone glabra 120, 154, 155, 178 , 223,224

Chenopodium album 25, 29, 49, 50, $60,87,94,104$, I 14, 126, 146, 160, I 33, I87, I88, 200, 208, 209, 2 I 8 $253,259,265,278,284,293$

glaucum 50

hybridum 126

leptophyllum 25,50
Chionanthus virginica $5^{\mathrm{I}}$

Chrysopsis villosus $23 \mathrm{I}$

Chloris elegans 253

verticillata 18

Chrysopogon avenaceus 99, 154, 179

Chrysothamnus nauseolus 73

Cicuta maculata $32,53,89,90,94$, 106, I14, 128, 146, 242

Cimicifuga americana $5 \mathrm{I}$ racemosa $5 \mathrm{I}$

Cineraria palustris 255

Cinna arundinacea 12,163

Clematis Douglasii 57, 232, 242

Drummondii 57, 241, 242, 247, 276

Flammula 276, 292

Fremontii 56,57

lasiantha 57

ligusticifolia $57,105,232,233,247$, $252,256,276,292$

Scottii 51, 56, 57

viorna 56,57

virginiana $5 \mathrm{x}, 56,57,6 \mathrm{r}, 87,94$, I05, I14, I27, I46, I80, 232, 233 , $242,276,292$

vitalba 104,276

Cleome serrulata 49,50

spinosa $32,49,60,208,209,218$

Cleomella parviflora 50

Collomia linearis 236,247

Comandra pallida 39 umbellata $39,42,67,77,123,186$, 200

Convallaria majalis 180,278

Convolvulus sepium 3,5

Corydalis aurea $160,187,225$ glauca 160 montana 209 sempervirens 160,188

Crataegus apiifolia 172 cerronis I57, I65, I72, I74, I75, I95, 20I, 2II, 216, 219, 238, 248 coccinea $65,112, I_{5}, 157,164,166$,

I72, I74, I75

cordata II 3, I I 5, I73

flavo-carius 173

Marshallii 172

Phaenopyrum 173

Pringlei 90, 93, 95, 130, 143, 146 , 


\section{A THU : Cutures 32}

$147, x 65,169,174,175,237,247$

punctata 106, 112, I15, 129, 130,

$144,146,157,164,172,174,175$,

I94, 20I, 237

sp. 107, 113, 130,131, 146, 147, 157, 170

tomentosa 108, 193, 194, 201, 211, $2 \times 7,219$

Cydonia vulgaris 157, 194, 195, 201 , 210

Cyperus esculentus 74, 78

Dactylis glomerata 19

Dalea laxiflora 122, 142

Dasystoma flava 123

Decodon verticillatus $10 \mathrm{x}, \mathbf{1 2 x}, 123$, $126,245,248$

Delphinium formosum 179

Geyeri 232

scaposum 168,180

tricorne $100,122,180$

Dirca palustris $41,42,56,57,81,82$, 86 , 101, 122, 154, 162, x78, 179, $180,181,223,224,259$

Distichlis spicata $25,29,48,49,60$, $67,77,87,94,104,114,125,146$, I60, I73, I8I, 187, 200, 206, 208, $209,218,259,265,272,275,278$, $284,289,293$

Dodecatheon Meadia 64

Doellingeria umbellata 184,224

Dulichium arundinaceum 121, 240, $246,254,264$

Draba caroliniana 100

Eatonia pennsylvanica 40,42

Eleagnus angustifolia 180,182 argentea $224,232,252,269,270$

Eleocharis palustris $17,74,78,83,87$, 94, 124, I46, 181

Elephantopus carolinianus 198, 243

Elymus brachystachys 100

canadensis $32,45,5 \mathrm{I}, 6 \mathrm{r}, 88,94$, $162,163,174,180,232,247,270$, 275,276

condensatus 100,262

striatus $16 r, 162,174$

virginicus $25,29,33,42,5 x, 60,162$,

$174,241,247,262,265,276,292$

Erigeron annuus $11,13,14,19,21,27$,
$28,45,52,6 x, 102, x 11,153,182$, 225,234

arenarioides [123]

philadelphicus 22, 28

Eriocoma cuspidata ror

Eriophorum angustifolium 255

polystachyon 256

tenellum 256

virginicum 256

viridicarinatum $255,256,265$

Erysimum asperum 49, 60, 68, 77

Euonymus obovatus $17,46,54$

Eupatorium perfoliatum I1, 18, 32,

$74,78,87,94,124,146$

serotinum $154,18 x$

Euphorbia arkansana coloradensis ror commutata $36,182,276$

corollata $50,60,67,77,105,224$,

$25 x, 269,276,277$

cyparissias $192,193,224$

dentata, 19, 28

humistrata 18, 19, 28

Ipecacuanhae 277

maculata 4 , 10,11

marginata 18, 19, 105, 114

nutans $4,10,11,18,19,28$

robusta 267

Euthamia graminifolia $184,199,229$, $234,242,243,246$

Evolvulus pilosus 197, 202

Falcata comosa $64,8 \mathrm{r}, 99$, 100

Festuca confinis $64,100,196,202$

Thurberi 256, 265

Forestiera porulosa 51

Fraxinus lanceolata ( $F$. viridis) [8], $51,60,67,77,103,114,127,146$, $160,174,180$

Gaura biennis $158,[173], 184$

Geranium carolinianum 82 maculatum $13,19,22,32,53,61$, $69,78,8 \mathrm{I}$

palustre 82

pratense 82

pusillum $69,8 \mathrm{r}, 82$

Robertianum 69, 8 I

Gillenia stipulacea $117,144,145,166$

Glaux maritima 89,90 
Grindelia squarrosa 122, 154, 155, 179, 188, 189, 191, 196, 200, 231

Gutierrezia Sarothrae 64, 72, 73, 78, 23I, 247

Helianthus angustifolius 224

annuus $34,42,48,60,69,78,287$ decapetalus 48

divaricatus 48,60

grosse-serratus $17,23,28,34,47$, $48,60,69,78$

hirsutus 48,60

Kellermani 48, 60

laetiflorus $47,48,60$

Maximiliani $18,23,28,34,48$

mollis $34,42,47,48,60$

occidentalis 48,60

orygalis 48

rigidus 34

scaberrimus 48,60

strumosus $\mathrm{I7}, 23,34,48,60$

tomentosus $34,48,60$

tuberosus 34,48

Heliotropium curassavicum 154

Hepatica acuta II

acutiloba $7 x, 78,89,94$

Hibiscus militaris $45,123,142,155$, I $87,223,24 \mathrm{I}$

Moscheutos 81, 82, 100, I42

Hippurus vulgaris 89

Holcus lanatus 252

Homalocenchrus virginicus 17

Hordeum jubatum I9, I54, 252

nodosum [264]

pusillum $263,264,265$

vulgare $88,94, \mathrm{I} 63$

Houstonia caerulea 92, 128, 129, 146, 277, 279

purpurea $82,83,92,99$

Hydrangea arborescens 277

Hydrocotyle australis 253

Hydrophyllum appendiculatum 17, 18, $31,64,66$

capitatum 99, 179, 180, 196, 198, $207,232,262,265$

Fendleri 223, 232

virginicum 99, 100, 101, 121, 122,

I54, I55, I62, I68, I79, I81, 189, 223

Hymenoclea monogyna 244, 248
Hypoxis erecta 99, I0I

Ilex opaca 100

Impatiens aurea II, 14, 17, 18 , i9 25, $29,32,33,42,51,56,60,161, x 62$, I74, I80, I89, 201

Ipomoea pandurata 5, 122, 162, 239

Iris versicolor $17,92,99,102,121$, $197,223,253,277,278,282,284$

Isopyrum biternatum $18,37,8$ r. 82 , $122,178,180$

Iva frutescens $122,126, \mathrm{~J} 34,153$

Juncus balticus ror, 155, 191, 192, 20 I, 235,247

dichotomus 93

effusus $64,82,83$

tenuis $17,92,93,95,106$, I 4

Juniperus communis 133

horizontalis $151,170,171,175$

monosperma 217, 219

scopulorum 93, 95, 107, II2, I14, II $, 130,131,146,147,165,174$, 194, 201, 237, 247

sibirica 107, 108, I15, 130, 131, 132, $146,147,150,151,164,165,174$, 193, 194, 201, 210, 211, 218, 219, 238,248

utahensis II3, II5, 2II, 215, 216, $218,219,237,247$

virginiana $64,77,90,95,106,107$, I08, I14, I15, 129, I30, 144, 145, $146,147,157,164,165,166,169$, I71, 173, 174, 175, 193, 194, 195, 20I, 210, 216, 218, 219, 242, 247

Koeleria cristata I37, I39, I47, I89, $200,213,234,247,273,275,292$

Kuhnia eupatorioides $74,78,124,145$ Hitchockii 124, 145

Kuhnistera purpurea 17

Laciniaria Langloisii 243 punctata 120, 154, 155, I78, 179, 2I I , 230, 243, 273, 275

pycnostachya $8 \mathrm{I}$

scariosa $17,18,155,18 \mathrm{r}, 189,198$, $2 \mathrm{II}, 236$

spicata 99, 100, 101, 121, 154, 155, I78, I79, I8I

Lactuca canadensis $18,32,81,82,85$, $92,94,99,185,200$

sativa $84,85,94,154,185,200$ 


\section{Arthur: Cultures of Uredineae, 1890-19́1Z'F 257}

scariola (partly under $L$. virosa)

[85], [92], [94], 182

Larix decidua ( $L$. europaea) $\times 7,35$, $42,46,47,54,55,60,6 \mathrm{x}, 64,84$, 94

laricina ( $L$. americana) $46,55,60$, $64,77,91,133,147,198,212$ Lyallii 54,55

Lathyrus decapetalus $10 x$ palustris 101, 182

Ledum groenlandicum 195, 202

Lepachys pinnata 99 , roo

Lepargyraea canadensis $153,154,155$, $168,179,180,18 x, 182,224,252$ Lepidium apetalum [17], [45], [49], [50,] [6o]

densiflorum [17], [45], [49], [50], [60]

virginicum 49, 60, 68, 77, 209

Leptilon canadense 19, 22, 28

Lespedeza capitata 36,42

Leucocrinum sp. 25I

Liatris punctata 273

Libocedrus decurrens $143,147,211$, 219

Ligularia sibirica 255

Ligustrum ovalifolium $5 \mathrm{I}$

vulgare $51,67,127$

Lilium elegans 279

umbellatum 279, 280, 284

Linum Lewisii 9I, 95

usitatissimum 9 I, 95

Lithospermum angustifolium I54, 155, 230

arvense 154

canescens $154,168,179$, I 80

officinalis 224

Lobelia syphilitica 46

Lonicera japonica 64

Lycium pallidum 260, 265

vulgare 260,265

Lycopsis arvensis (partly under Anchusa officinalis) 128, 146,154 , [257], [265]

Lycopus americanus $6,12,52,6$ r, 87 , $94,103,114,125,146,186,200$, $208,218,230,247$

communis 125,146
Lygodesmia juncea 212, 219

Lysimachia quadrifolia $76,83,100$, $106,121,164,178,179$

terrestris $76,83,178,181,182,191$, 197

thyrsiflora 76

Macrocalyx Nyctelea 46, 8x, 82, 121 , 180,197

Mahonia Aquifolium 123, 138, 147 , 180

Maianthemum canadense $278,280,282$

Malus coronaria 90, 95, 107, 129, 146, $157,195,210,217,218$

ioensis $164,165,174$

Malus 64, 65, 77, 106, 107, 108, 114 , I I $5, I_{29}, I_{30}, I_{3} 1, I_{46}, I_{57}, I_{66}$, I93, 20I, 217

Malvastrum coccineum 206, 225, 24I, 271, 272, 275

Medicago sativa 182, 193, 201, 210 , 218

Menyanthes trifoliata ror

Meriolix serrulata $178, \mathbf{x} 84,199,208$

Mertensia virginica IQ0, 155

sp. IOI

Mimulus ringens $45,154,155,162$, I79, 18 I

Monolepis Nuttalliana 126, 187, 188 , 208

Muhlenbergia diffusa 82

glomerata [142], [147], 161, 174

gracilis 187

gracillima $27 \mathbf{r}, 275$

mexicana 45,142 , [ 147 ]

Porteri [240]

racemosa $17,45,187,200$

tenuiflora roo

Myosotis palustris 81, 83, 100, 154, 162,168

Myrica cerifera 100, 134, 178, 179, $180,197,246,248$

Napaea dioica 6, 17, 25, 32, 63, 81, $82,83,87,98,99,100,101,121$, I22, 123, I6 I, 168, 187, $24 \mathrm{I}$

Naumburgia thyrsiflora 76

Notholcus lanatus 252

Nothoscordium bivalve (N. striatum) $263,264,265$ 
Oenanthe aquatica 90 californica 90

Onagra biennis (Oenothera biennis) 6 , II, 19, 20, 21, 22, 27, 28, 32, $52,61,66,77,85,86,94,124,145$, I53, I58, I73, I84, I $85,199,208$, 218,234

pallida 207

Onosmodium hispidissimum 180 occidentale 179,232

Orchis spectabilis 178

Ornithogalum bivalve 263 umbellatum 263

Oryzopsis cuspidata 101

Oxalis Bowiei 68

corniculata 68

cymosa $17,18,32,59,61,68,78$

Ortigiesi 68

violacea 46

Oxygraphis Cymbalaria 137, 147, 208, 218

Oxypolis rigidus 89,106

Oxytropis Lamberti 192

Panicularia americana 18

Panicum capillare $11,18,32,63,82$, I00, 121, 224, 251, 276 virgatum $50,60,64,67,77,105$, II $4,123,155,181,224,269$

Parthenium integrifolium 82, 92

Pastinaca sativa 89

Pentstemon alpinus 186,200

barbatus $\mathrm{I} 86$

hirsutus ( $P$. pubescens) 5, 6, 32, 33, $39,42,67,87,94,122,123,186$, 200

Petalostemon purpureus $154,155,168$, I79, $180,18 \mathrm{r}$

Phacelia bipinnatifida ror, I22, 154, 155

heterophylla 179, 232

tanacetifolia 223

Phalaris arundinacea $180,278,284$

Phaseolus diversifolius 36

Philadelphus coronarius 216, 2I7, $219,237,247$

Keteleerii 237, 247

Phleum pratense 122

Phlox divaricata 17, 81, 181, 198 subulata $8 \mathrm{I}$
Phragmites communis ( $P$. Phragmites) 2, 26, 29, 104, 114, 160, I $74,208,218,25 \mathrm{I}, 294$

Phryma leptostachya 99, III, II5, 178

Physalis heterophylla 32

pubescens 225

sp. 180

Physalodes Physalodes 17, 32

Picea canadensis 17,277

mariana 195, 202

Pinus palustris 239, 248

rigida 46

taeda 198, 202, 211, 219, 238, 239, 243,248

virginiana $84,94,195,202$

Pisum sativum 182

Plantago aristata $24,279,284$

eriopoda 24

lanceolata 23, 279, 284

Purshii 24

Rugelii 23, 28, 279

virginica 23,24

Poa compressa 19

longiligula ror

Podophyllum peltatumi 59, $6 \mathrm{r}$

Polemonium reptans $32,45,64,65$, $76,81,82,99$, 101, $122,156,162$, $179,181,197,198,202,261$

Polygala Senega $45,75,76,81,82$, $83,99,101,154,155,162,181$, 182

Polygonatum biflorum $154,278,282$, 284

commutatum $180,278,282,284$

Polygonum amphibium 82

aviculare $268,273,275$

emersum $18,31,53,61,69,78$

pennsylvanicum 18

scandens $8 \mathrm{I}$

virginianum 18

Polymnia canadensis 82,92 , ror

Populus angulata 36

angustifolia 36

balsamifera 36

canadensis 36

deltoides $17,35,36,42,46,60,64$, 77

grandidentata 36 


\section{6}

Arthur: Cultures of Uredineae, $1899-1917$ \& 859

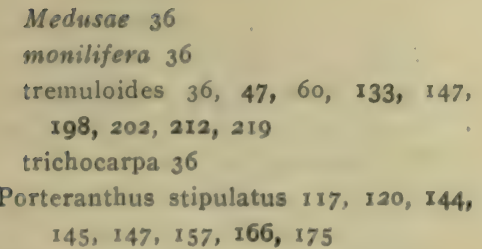

Prunus americana $7 x$

Cerasus $7 \mathrm{I}$

divaricata 70

pumila 89,94

serotina $71,78,89,94$

spinosa 70,71

virginiana $7 \mathrm{I}$

Pseudotsuga mucronata 198, 199, 202, 212, 219

Psoralea Onabrychis $18,64,76,81$, $99,100,101,122,162,168$

Ptelea trifoliata 6, $8,22,28,50,60$, 260,265

Puccinellia airoides $137,147,208,218$

Pulicaria dysenterica $101,155,156$

Pulsatilla hirsutissima 26

Pyrus communis 113, 131, 157, 194, 217

japonica 93

Quamasia hyacinthina 18

Quercus alba 84

Phellos 239, 248

rubra $195,202,238,239,248$

velutina $\mathbf{8 4}, 94$

Ranunculus abortivus 40, 42, 215, 295

acris 252

bulbosus 252

cymbalaria 137, 292

recurvatus I0I

sceleratus 251,252

septentrionalis $26,98, \mathbf{1 5 5}$

Rhamnus alnifolia $180,187,200$

caroliniana 52, 61

cathartica 52, 61, 180,252

lanceolata 52, 6r

Purshiana 252, 27x, 275

Ribes aureum $17,22,32,33,37,53$, 61,65

Cynosbati II, 12, 18, 19, 20, 22, 32, $33,37,38,42,53,61,86,94,9 y$, $102,111,113,133,178,182,199$,
$212,225,237,246,254,265,269$, 270

floridum $19,20,22,33,53,103,19 \%$ 254

gracile $12,17,19,22,65,77,86$, 94

Grossularia 42

longiflorum 254

rotundifolium 53, 6r, 66, 86, 94

rubrum $53,65,86,103,133$

Uva-crispa 20, 22, 33, 42, 53, 61, 65

Roripa sinuata 49,50

Rosa arkansana 47, 60, 106

carolina 47,60

humilis $23,28,47,60$

lucida 47

nitida 47,60

pratincola 106, Ir4

sp. 4

Rubus allegheniensis 207

Rudbeckia laciniata $63,64,65,76,8 \mathrm{r}$, $82,92,120,121,142,153,178$, $18 \mathrm{I}, 182,197,277,279,284$

triloba $63,64,178,179,180$

Ruellia ciliosa 69, 70, 78, 294 strepens $69,70,78,224,294$

Rumex crispus 2, 104, $114,160,174$ 208, 218

obtusifolius 2

Rynchospora :atba so t

Salix amygdaloides 54, 56, 61

Bigelowii 5 255

brachystac' $y \leq 55$

discolor I?

herbacea 56

longifolia 5

repens 56

sp. 84,94

Salsola Tragus 49,50

Salvia lanceolata 36,42

Sambucus canadensis $14,19,2 x, 22$, $28,32,52,65,77,85,94,124,146$, 158,159

Sarcobatus vermiculatus 87, 104, I26, 146,208

Schedonnardus paniculatus 17,100 , I22, 179, 207, 27 I, 275

Scirpus americanus 109,115 
atrovirens $6,12,52,61,86,94,103$, I14, I25, 186, 200, 229, 247

cyperinus $125,146,208,218$

Eriophorum 230

fluviatilis $89,90,94,106,114,128$, $146,242,247,253$

maritimus 90

microcarpus 223,230

rubrotinctus 223,230

sylvaticus 223,230

Scolochloa festucacea 252

Secale cereale 88, I27, I46, [257], 265

Senecio aureus $255,256,265$

cacaliaefolius 255

Douglasii (error for S. spartioides) ductoris 256

lugens (error for S. spartioides)

obovatus $17,18,32,81,82,92,99$,

IOI, $120,121,240$

palustre 255

spartioides [178], [180], [189],

[197], [200], [231], 247

Sidalcea oregana $155, x 79,191,207$

sp. $16 \mathrm{I}$

Sieglingia seslerioides 6

Silphium integrifolium $72,78,82,88$, 92,94

laciniatum 93

perfoliatum $32,38,65,72,82,83$,

$88,92,93,94,95$, ror, ro6, 109, I 4,236

terebinthinaceum $82,88,92,94$

Sium cicutaefolium 90, 242, 247, 253 latifolium 89

Sisyrinchium gramineum (S. graminoides) 128, 129, 146

Sitanion elymoides 262 longifolium $162,163,174,187,200$ Smilacina stellata 99,282

Smilax herbacea 26, 29, 8 I

hispida 26, 29, 33, 42,67, 77, 100, I04, I I 4, I21, I 22, I27, I34, I 35, I 47, I6o, I73, I87, 200, 25 I rotundifolia 134,135

Solidago caesia $27,29,38,42$, I 78 canadensis II, I4, $19,20,27,29,32$, $37,38,39,42,45,66,73,77,78$,
98, 99, IOI, I02, I10, III, I24, I46, I $53, I 78, I 82, I 84,188,190$, $200,224,229,231,234,238,240$, $242,243,246,247,254,264,279$ flexicaulis 37,42 glaberrima 238,246

lanceolata 184

missouriensis 238

mollis $231,238,246$

nemoralis 184,190

rigida $18,27,29,32,38,179$

rugosa I 84, I90, 20I, 238, 242, 246 serotina II, 20, $2 I, 27,29,37,38$, 42

trinervata 73,78

ulmifolia $27,29,46$

Sophia incisa (error for S. brachycarpa) [49], [6o], [68], [77]

incisa (error for S. intermedia) [49], [50]

Sorbus americana 90, 93, 95, 100, 107, II2, II3, II4, I I 5, I30, I3I, $132,146,147,157,165,166,174$, I94, $20 \mathrm{r}, 2 \mathrm{II}, 2 \mathrm{Ig}$

Aria 133

aucuparia $133,165,174,211,217$

hybrida 133

torminalis $r 33$

Spartina cynosuroides (partly for S. Michauxiana) [8], [3I ], [5I], $[60],[67],[75],[76],[77],[78]$, [83], [103], [106], [114], [127], [146], [156], [160], [164], [174], [18r] 258,265

gracilis 154

Michauxiana (partly under S. cynosuroides) [8], [3I], [5I], [60], $[67],[75],[76],[77],[78],[83]$, [103], [106], [114], [127], [146], [156], [160], [164], [174], 181, I88, I98, 200, 202, 236, 247, 258, 26 I, 265, 27I 275,28 r, 283, 284 patens $18 \mathrm{r}$ polystachya 127,146 stricta 127,146 sp. I 80

Sphaeralcea incana 223, 240, 247 lobata 223, 224, 24I, 247 


\section{A}

\section{Spiraea lobata 5}

stipulata 145

Sporobolus asperifolius $63,179,206$, 240,247

cryptandrus (partly error for Stipa viridula) [rog], [115], 223, 270, 275,280

heterolepis $18,279,284$

longifolius $7,17,22,28,50,60,67$, 77,225

neglectus $32,182,274$

vaginaeflorus $273,275,280$

Stanleya pinnata 50

Steironema ciliatum $46,63,65,66,76$, $78,83,106,114,156,157,164$, 174, 18 $1,198,236,26 \mathrm{x}, 265,267$, $27 x, 275,282,283$

lanceolatum $76,83,156,157,164$, $174,236,282$

Stenolobium molle 73 stans $73,78,88,94$

Stipa comata $75,231,247$ spartea $18,57,61,163,188,200$ viridula (partly under Sporobolus cryptandrus) 75, 78, [109], [115], $154,163,174,213$

sp. 188,200

Strophostyles helvola 36,42

Stylophorum diphyllum 17

Symphoricarpos oreophilus 197 parviflorus $x 68$

pauciflorus $45,153,154,179$

racemosus $17,18,32,45,63,98,99$, $100,101,122,154,155,179,180$, $181,189,196,202$

Syringa vulgaris $5 \mathrm{I}$

Taraxacum Taraxacum 13

Tecoma mollis 73

radicans 73

stans 73

Thalictrum alpinum $154, \quad \mathbf{5} \mathrm{r}_{2} \quad \mathbf{1 7 4}$, 232

dioicum 64, 76, 81, 82, 99, 122, 127, $139,140,147,154,161,168,178$, $233,242,256,265$

Fendleri $140,223,232,242,256$ occidentale 140

polygamum ror, 122, 179 purpurascens 154

sparsiforum 139, 140

venulosum 140

Tissa canadensis $180,181,188,190$, 209

Tithymalis arkansanus coloradensis 154

Tridens flavus (Tricuspis seslerioides, Triodia cuprea) 6, 22, 28, 50, 60, 259, 265

Trifolium carolinianum 244, 248 medium 193,210 pratense $182,193,210$ repens 193,210

Trillium cernuum 180,278

recurvatum $37,81,82,98,282$

Triosteum perfoliatum $8 \mathrm{r}$, I00, I0I

Tripsacum dactyloides 18

Trisetum majus 180, 213, 219 subspicatum 213, 214, 219, 234, 247

Triticum vulgare $19,28,88,94,162$, $163,174,276$

Troximon glaucum 136

Tsuga canadensis 91,277

Ulmaria rubra 5

Urtica gracilis II, 19, 22, 28, 52, 63, $66,77,103,109,113,134,158$, $159,173,186,197,200,269,270$

Uvularia grandiflora 179, 180,278 , 280,282

perfoliata 45

Vaccinium pennsylvanicum 166,175

Vitis-idaea 167

Vagnera racemosa 278,282 stellata $180,225,278,280,281$, 282, 284

Verbena stricta 7, $17,22,28$ urticifolia $18,22,28,50,60,67,77$, 122

Vernonia arkansana I2I crinita 198,202 fasiculata $239,243,248$ gigantea 2II, 219 sp. 274,275

Viola cucullata $11,32,37,8 x, 99,100$, $101,120,123,155,163,174,230$, 247

Nuttallii 230,247 


\section{9}

papilionacea 63,76

pubescens 82

primulaefolia 164,230

septentrionalis 180

sororia 154

striata $98,99,23$ I

Viorna Douglasii 180

Scottii I05, II4

Purdue University,

LAFAYETTE, INDIANA.

\section{Mycologia}

Xanthium canadense $11,14,17,18$, 19, 22, 32, 46, 71, 74, 78, 236

sp. 88, 94

Xanthoxylum americanum $18,32,50$, $63,100,142,168,179,206,207$, 225

Zea Mays $18,[59], 61,68,69,78$ 

$3^{3}$ 




$$
\text { . }
$$

. 


I BINDING LICT JAN 151930

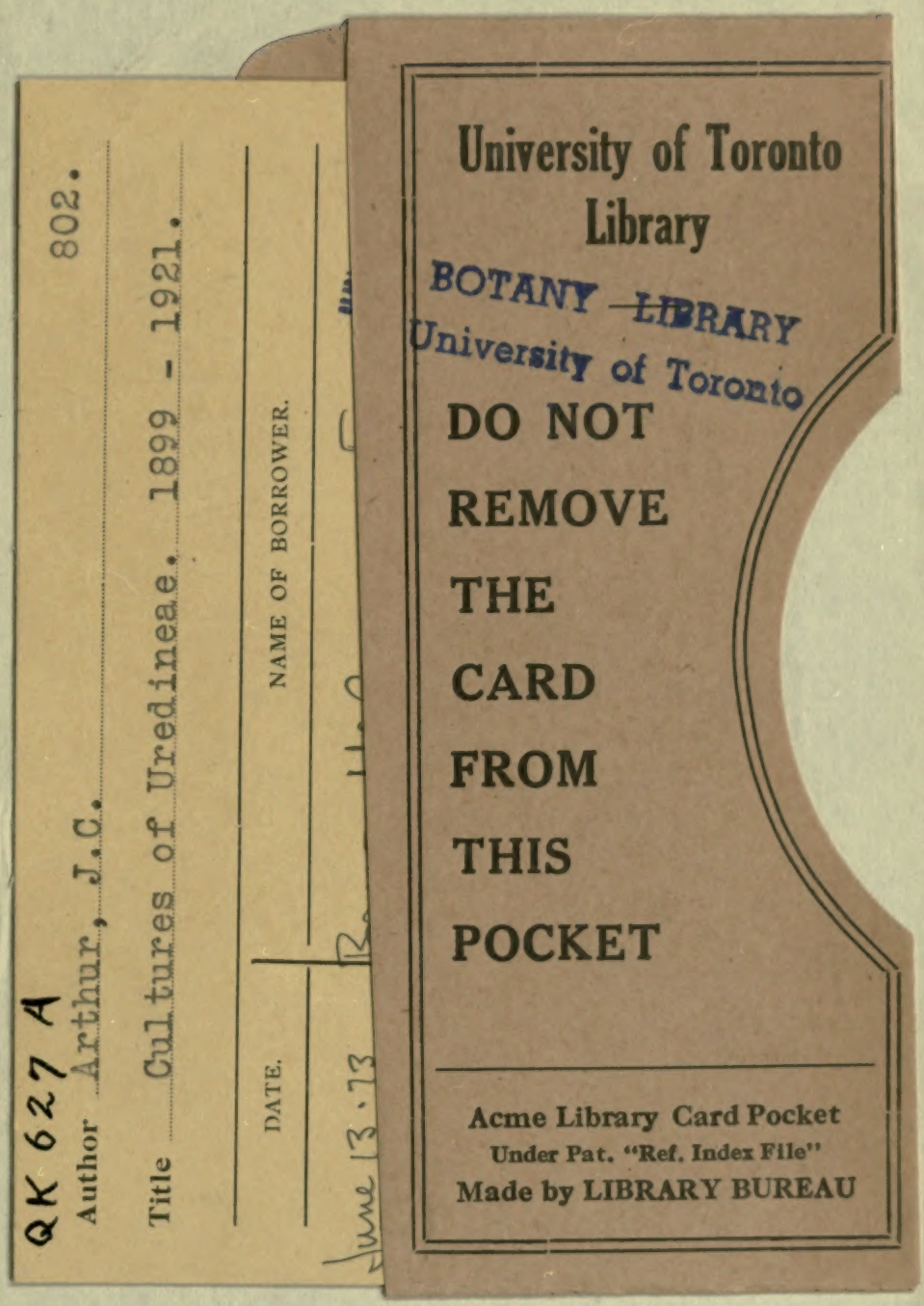


